\title{
PRODUÇÃO DE FORRAGEM E TRANSFORMAÇÕES DO NITROGÊNIO DO FERTILIZANTE EM PASTAGEM IRRIGADA DE CAPIM TANZÂNIA
}

\section{Geraldo Bueno Martha Júnior}

Tese apresentada à Escola Superior de Agricultura "Luiz de Queiroz", Universidade de São Paulo, para obtenção do título de Doutor em Agronomia, Área de Concentração: Ciência Animal e Pastagens.

PIR A C I C A B A

Estado de São Paulo - Brasil

Junho -2003 


\section{PRODUÇÃO DE FORRAGEM E TRANSFORMAÇÕES DO NITROGÊNIO DO FERTILIZANTE EM PASTAGEM IRRIGADA DE CAPIM TANZÂNIA}

\section{Geraldo Bueno Martha Júnior}

Engenheiro Agrônomo

Orientador: Prof. Dr. Moacyr Corsi

Tese apresentada à Escola Superior de
Agricultura "Luiz de Queiroz",
Universidade de São Paulo, para
obtenção do título de Doutor em
Agronomia, Área de Concentração:
Ciência Animal e Pastagens.

PIR A C I C A B A

Estado de São Paulo - Brasil

Junho - 2003 
Dados Internacionais de Catalogação na Publicação (CIP) DIVISÃO DE BIBLIOTECA E DOCUMENTAÇÃO - ESALQ/USP

\author{
Martha Júnior, Geraldo Bueno \\ Produção de forragem e transformações do nitrogênio do fertilizante em pastagem \\ irrigada de capim Tanzânia / Geraldo Bueno Martha Júnior. - - Piracicaba, 2003. \\ $149 \mathrm{p}$. \\ Tese (doutorado) - Escola Superior de Agricultura Luiz de Queiroz, 2003. \\ Bibliografia. \\ 1. Capim-Tanzânia 2. Fertilizantes nitrogenados 3. Forragem 4. Nitrogênio 5. \\ Pastagem irrigada 6. Pastejo 7. Relação solo-planta I. Título
}

CDD 633.2

"Permitida a cópia total ou parcial deste documento, desde que citada a fonte - 0 autor" 
À minha esposa, Paula,

pela dedicação, apoio e estímulo,

e aos meus sobrinhos, Rodrigo e Lígia,

pelo carinho que sempre demonstraram,

\section{Dedico}

Aos meus pais, Beatriz e Geraldo (in memorian), pelo exemplo, carinho, dedicação e apoio que sempre demonstraram,

Ofereço 


\section{AGRADECIMENTOS}

Ao Professor Dr. Moacyr Corsi, pela amizade e pela inestimável contribuição à minha formação como profissional e como pessoa.

Ao Professor Dr. Paulo C.O. Trivelin, pela amizade, valorosa colaboração e estímulo, que possibilitaram que este trabalho fosse realizado.

À minha esposa, Paula, pelo estímulo, paciência e compreensão durante todo o treinamento de doutorado.

À minha família, em especial à minha irmã, Diana, e à minha madrinha, Therezinha, pelo constante apoio e incentivo.

Ao Departamento de Zootecnia da ESALQ/USP, por ter possibilitado à execução dos trabalhos da tese.

À Fundação de Amparo à Pesquisa do Estado de São Paulo (FAPESP), pelo financiamento do projeto e pela concessão da bolsa de estudos.

À Embrapa Cerrados, na sua chefia, Dr. Carlos Magno Campos da Rocha (Chefe geral) e Dr. Ronaldo Pereira de Andrade (Chefe de P\&D), pelo estímulo e ajuda na realização do curso.

Ao Dr. Marco Antônio Penati, ao Dr. Lourival Vilela e ao Dr. Luis Gustavo Barioni, pela amizade e pelas preciosas discussões.

Aos amigos Alderbal Galvani, Francisco Duarte Fernandes, Allan Kardec Braga Ramos, Cláudio Takao Karia, Rodrigo Fernando Maule, Gleuber M. Teixeira, José Roberto Galvani, Antônio Carlos Gomes e Ravi Datt Sharma, pela amizade e pelo constante apoio.

Ao Dr. José Albertino Bendassoli, à Srta. Raquel F. Ignoto e à toda equipe do Laboratório de Isótopos Estáveis (CENA/USP), pela importante colaboração nas determinações isotópicas. 
À equipe de pós-graduandos e de estagiários do "Projeto Capim", em especial ao Eng. Agr. Fábio L.A. Maya, ao Eng. Agr. Florencio Queiroz Neto e ao Eng. Agr. Miguel José Thomé Menezes, pela dedicação e apoio na realização dos trabalhos.

Aos colegas da Embrapa Cerrados e do Curso de Pós-graduação em Ciência Animal e Pastagens (ESALQ/USP), pela amizade e pelo constante apoio.

À Sra. Eliana M.G. Sabino, pela gentileza de conferir a normatização das citações de literatura, e à toda equipe da Biblioteca Central da ESALQ/USP, da Biblioteca do CENA/USP e da Embrapa Cerrados, pelo profissionalismo e boa vontade.

A todos que de alguma forma contribuíram para que esse trabalho se tornasse uma realidade. 


\section{SUMÁRIO}

Página

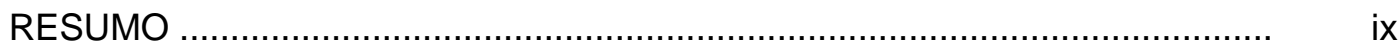

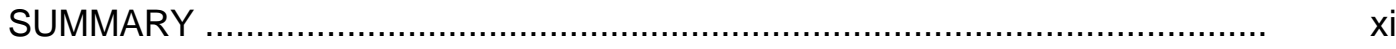

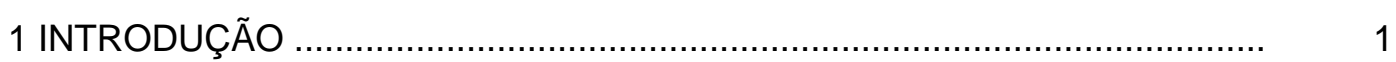

2 REVISÃO DE LITERATURA .......................................................... 6

2.1 O capim Tanzânia ......................................................................... 6

2.2 Efeito da irrigação sobre a produção da planta forrageira .......................... 8

2.2.1 Irrigação de pastagens durante a época seca do ano ............................ 9

2.2.2 Irrigação de pastagens durante o período das águas ............................... 10

2.2.3 Irrigação de pastagens durante a transição dos períodos de seca e de águas ....................................................................................... 11

2.3 Efeito do manejo da desfolha sobre a produção da planta forrageira .......... 11

2.4 Efeito da fertilidade do solo sobre a produção da planta forrageira ............. 13

$2.5 \mathrm{O}$ nitrogênio no ecossistema de pastagens ........................................... 14

2.5.1 Influência do nitrogênio sobre a fisiologia da planta forrageira ................ 16

2.5.2 Efeito do manejo da pastagem sobre a nutrição nitrogenada da planta forrageira .................................................................................. 19

2.5.3 Adições de nitrogênio ao sistema solo-planta forrageira .......................... 21

2.5.3.1 Adições de nitrogênio via atmosfera .................................................... 21

2.5.3.2 Adições de nitrogênio via fertilizantes ................................................ 22

2.5.4 Perdas de nitrogênio do sistema solo-planta ........................................... 27

2.5.4.1 Perdas de amônia $\left(\mathrm{NH}_{3}\right)$ por volatilização .......................................... 28

2.5.4.2 Perdas de nitrogênio por desnitrificação .............................................. 33 
3 EFEITO DA INTENSIDADE DE DESFOLHA SOBRE A PRODUÇÃO DE FORRAGEM DO CAPIM TANZÂNIA IRRIGADO DURANTE O INVERNO ... 36

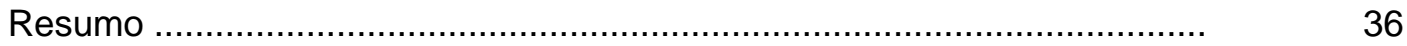

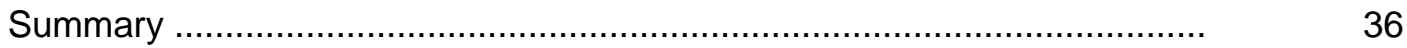

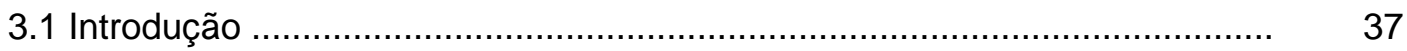

3.2 Material e Métodos ............................................................................ $\quad 39$

3.3 Resultados e Discussão ..................................................................... 41

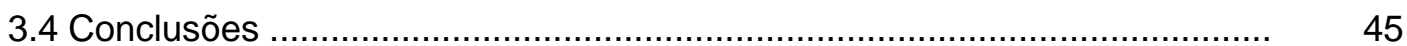

4 EFEITO DA INTENSIDADE DE DESFOLHA SOBRE A PRODUÇÃO DE FORRAGEM DO CAPIM TANZÂNIA IRRIGADO DURANTE A

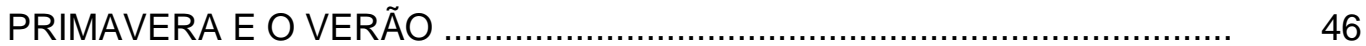

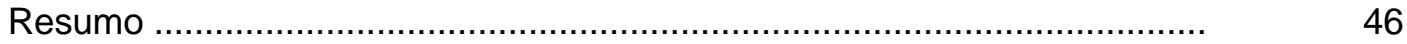

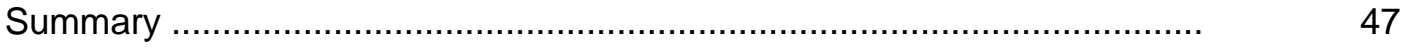

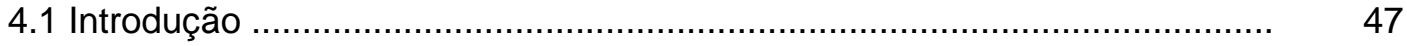

4.2 Material e Métodos ............................................................................ 49

4.3 Resultados e Discussão ................................................................... 51

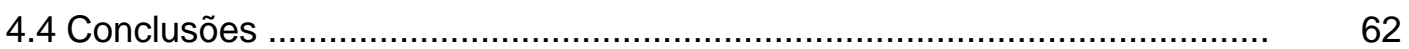

5 EXIGÊNCIAS DO TAMANHO DA PARCELA EM ESTUDOS DE RECUPERAÇÃO DE FERTILIZANTE- ${ }^{15} \mathrm{~N}$ POR CAPIM TANZÂNIA IRRIGADO SOB DIFERENTES INTENSIDADES DE DESFOLHA ............. 63

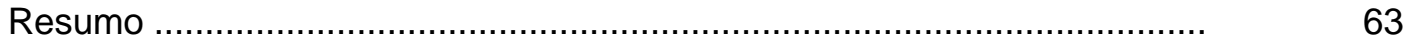

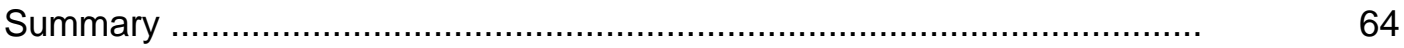

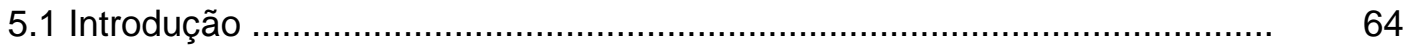

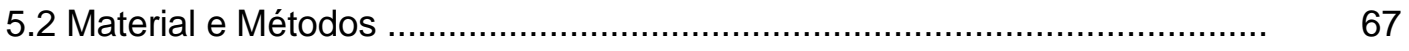

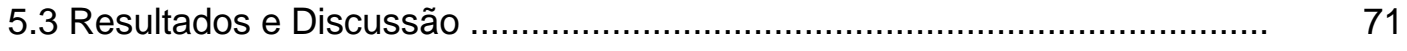

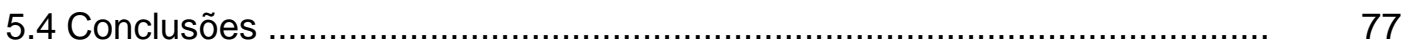

6 RECUPERAÇÃO DO NITROGÊNIO $\left({ }^{15} \mathrm{~N}\right)$ DA URÉIA POR PASTAGEM DE CAPIM TANZÂNIA DURANTE O VERÃO.................................................... 78

Resumo ..........................................................................................

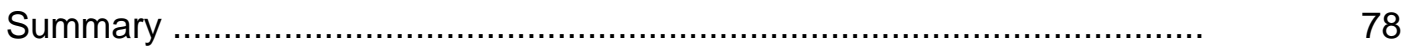

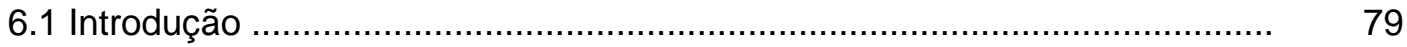

6.2 Material e Métodos ................................................................................. $\quad 79$

6.3 Resultados e Discussão ..................................................................... 82 
6.4 Conclusões

7 PERDA DE AMÔNIA POR VOLATILIZAÇÃO EM PASTAGEM DE CAPIM

TANZÂNIA ADUBADA COM URÉIA NO VERÃO ...................................... 89

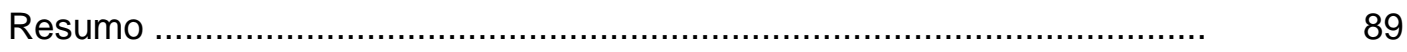

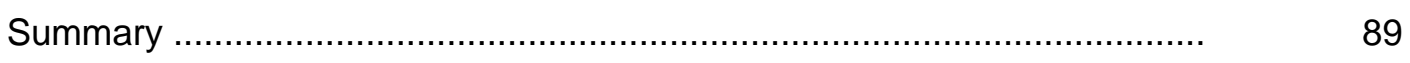

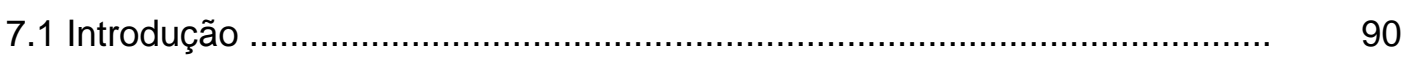

7.2 Material e Métodos ............................................................................ 91

7.3 Resultados e Discussão ..................................................................... 95

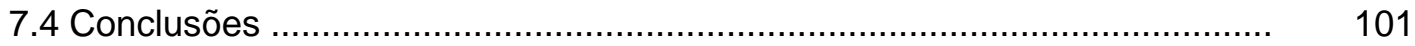

8 ABSORÇÃO FOLIAR DA AMÔNIA VOLATILIZADA DA URÉIA APLICADA AO SOLO POR PASTAGEM DE CAPIM TANZÂNIA .................................. 102

Resumo ................................................................................... 102

Summary ........................................................................ 102

8.1 Introdução ................................................................................. 103

8.2 Material e Métodos .......................................................................... 104

8.3 Resultados e Discussão ..................................................................... 106

8.4 Conclusões .................................................................................... 109

9 DISCRIMINAÇÃO DO ${ }^{13} \mathrm{C}$ ASSOCIADA À NUTRIÇÃO NITROGENADA E À PRODUTIVIDADE DE PASTAGEM IRRIGADA DE CAPIM TANZÂNIA ........ 110

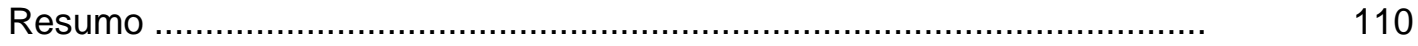

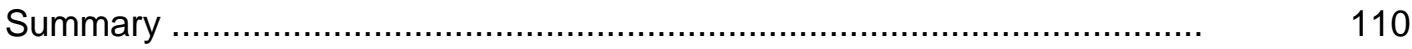

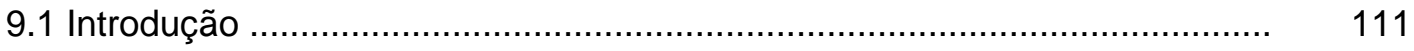

9.2 Material e Métodos ....................................................................... 112

9.3 Resultados e Discussão ................................................................ 114

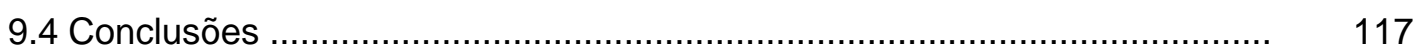

10 CONCLUSÕES ....................................................................... 118

REFERÊNCIAS BIBLIOGRÁFICAS ................................................. 119 


\title{
PRODUÇÃO DE FORRAGEM E TRANSFORMAÇÕES DO NITROGÊNIO DO FERTILIZANTE EM PASTAGEM IRRIGADA DE CAPIM TANZÂNIA
}

\author{
Autor: GERALDO BUENO MARTHA JÚNIOR \\ Orientador: Prof. Dr. MOACYR CORSI
}

\section{RESUMO}

Apesar de o manejo da pastagem ser um componente chave em sistemas pastoris, poucos esforços foram feitos para determinar a intensidade de pastejo adequada para pastagens tropicais, especialmente sob condições irrigadas. $O$ atrativo econômico de sistemas de pastagens irrigadas depende da elevada produtividade da pastagem, o que significa que fertilizantes nitrogenados precisam ser utilizados. Entretanto, para estabelecer medidas efetivas visando o manejo do nitrogênio $(\mathrm{N})$ é necessário entender o balanço entre entradas e saídas de $\mathrm{N}$ e a eficiência de ciclagem e transformações do $\mathrm{N}$ em sistemas de produção animal em pastejo. Nesse contexto, sete experimentos foram realizados para avaliar o efeito do resíduo pós-pastejo ou de níveis de fertilizante nitrogenado sobre a produção de forragem e a recuperação do $\mathrm{N}$ fertilizante em pastagem irrigada de Panicum maximum cv. Tanzânia. O resíduo póspastejo para pastagem de capim Tanzânia irrigada e adubada com $\mathrm{N}$ durante $\mathrm{o}$ inverno, considerando ciclo de pastejo de 36 dias, deve ser de aproximadamente 1.900 a $2.100 \mathrm{~kg} / \mathrm{ha}$ de massa seca verde. Para as estações de primavera e verão, a massa de forragem residual deve ser de cerca de 1.700 a $2.700 \mathrm{~kg} / \mathrm{ha}$ de massa seca verde. 
Esse manejo assegurou que a produção de folhas e a relação folha/haste fossem próximas do máximo. Parcelas de $1 \mathrm{~m}^{2}$, tendo uma touceira do capim em seu centro geométrico, foram adequadas para estudar a recuperação de fertilizante- ${ }^{15} \mathrm{~N}$, independentemente da intensidade de pastejo e estação do ano. O aumento da intensidade de pastejo resultou em decréscimo na massa da touceira. Quanto menor a massa da touceira, maior a dependência no $\mathrm{N}$-fertilizante. A combinação de elevada umidade do solo, ausência de chuva no dia subseqüente à adubação e alta temperatura determinaram baixa recuperação de ${ }^{15} \mathrm{~N}$-uréia no sistema solo-planta $(<$ $35 \%$ do $\mathrm{N}$ aplicado) e elevadas perdas de amônia por volatilização (> $40 \%$ do $\mathrm{N}$ aplicado) nos níveis de adubação superiores a $80 \mathrm{~kg} / \mathrm{ha}$ de $\mathrm{N}$ durante o verão. A absorção foliar da amônia volatilizada da uréia aplicada ao solo variou de 2,5\% (120 $\mathrm{kg} / \mathrm{ha}$ de $\mathrm{N}$ ) a $16,4 \%$ (40 kg/ha de $\mathrm{N})$ do nitrogênio volatilizado. Com adubações inferiores a $60 \mathrm{~kg} / \mathrm{ha}$ de $\mathrm{N}$ observou-se níveis subótimos de nutrição nitrogenada e tendência de maior discriminação do ${ }^{13} \mathrm{C}$ durante o verão. 


\title{
HERBAGE PRODUCTION AND TRANSFORMATIONS OF THE FERTILIZER NITROGEN IN IRRIGATED TANZANIA GRASS
}

\author{
Author: GERALDO BUENO MARTHA JÚNIOR \\ Adviser: Prof. Dr. MOACYR CORSI
}

\section{SUMMARY}

Whilst grazing management is a key component in pastoral systems little effort has been made to determine the adequate grazing intensity for tropical pastures, especially under irrigated conditions. The economical attractiveness of irrigated pasture systems depends on high pasture productivity, meaning that fertilizer nitrogen $(\mathrm{N})$ must be used. However, to make effective changes toward sustainable $\mathrm{N}$ management, an understanding of the balance between $\mathrm{N}$ inputs and outputs and the efficiency of $\mathrm{N}$ cycling and transformation within the grassland system is required. In this context, seven experiments were carried out to evaluate the effect of post-grazing residue or nitrogenous fertilizer levels on herbage production and on fertilizer- $\mathrm{N}$ recovery in irrigated Panicum maximum cv. Tanzania pasture. The post-grazing residue for irrigated, $\mathrm{N}$-fertilized Tanzania grass pasture during the winter, considering a 36-day grazing cycle, should be around 1900 to $2100 \mathrm{~kg} / \mathrm{ha}$ of green dry matter. During the spring/summer seasons the residual stubble mass should be around 1700 to 2700 $\mathrm{kg} / \mathrm{ha}$ of green dry matter. This management ensured that leaf production and leaf $/ \mathrm{stem}$ ratio were close to the maximum. A plot-size of $1 \mathrm{~m}^{2}$, with a tussock of the grass in its geometric center, was adequate to study ${ }^{15} \mathrm{~N}$-fertilizer recovery irrespective of grazing 
intensity and season of the year. Increasing the grazing intensity resulted in decreased tussock mass. The smaller the tussock mass the greater was the reliance on fertilizer$\mathrm{N}$. The combination of high soil water content, lack of rainfall in the day following fertilization and high temperature determined low urea- ${ }^{15} \mathrm{~N}$ recovery in the soil-plant system ( $<35 \%$ of applied $\mathrm{N}$ ) and high ammonia volatilization losses $(>40 \%$ of applied $\mathrm{N}$ ) at fertilizations levels higher than $80 \mathrm{~kg} \mathrm{~N} / \mathrm{ha}$ during the summer. The absorption of ammonia volatilized from urea applied to soil varied from $2.5 \%$ (120 kg N/ha) to $16.4 \%$ (40 kg N/ha) of the volatilized nitrogen. With fertilizations lower than $60 \mathrm{~kg} \mathrm{~N} / \mathrm{ha}$ it was observed sub-optimal $\mathrm{N}$ nutrition and a trend of higher ${ }^{13} \mathrm{C}$ discrimination during the summer. 


\section{INTRODUÇÃO}

A importância dos sistemas de produção animal em pastejo pode ser constatada sob diferentes pontos de vista. A pecuária bovina é importante por fornecer produtos de elevado valor biológico (carne e leite) para a alimentação humana, enquanto que, por um prisma social, ela pode contribuir para a fixação de trabalhadores no meio rural. A preocupação com o aquecimento global tem sido pauta cada vez mais discutida no Mundo e, atualmente, observa-se que esforços para reduzir as emissões de gases causadores do efeito estufa, como $\circ \mathrm{CO}_{2}$, assumem caráter de extrema relevância. Nesse sentido, pastagens bem manejadas podem desempenhar papel positivo sobre a qualidade do ambiente, pela captura do $\mathrm{CO}_{2}$ da atmosfera e estocagem desse carbono no solo (Corsi et al., 2001a).

Ademais, estimativas apresentadas por Arruda (1997) mostraram que $88 \%$ da carne bovina produzida do país advém de rebanhos mantidos exclusivamente em pastagens, o que estabelece a importância do pasto como principal fonte nutricional para os bovinos de corte no Brasil. A análise dessa informação, em associação com o percentual de participação da carne bovina na receita agrícola do país em 2000, de 21,65\% (Brasil, 2002), permite calcular que pelo menos 19\% da receita bruta agropecuária depende diretamente da atividade de pecuária bovina de corte a pasto $(21,65 \%$ da receita agrícola brasileira $\times 88 \%$ da pecuária de corte sendo realizada a pasto). Dessa maneira, fica evidente que a pecuária bovina é uma importante atividade econômica. Com efeito, ela responde por $30 \%$ e $13 \%$ do valor da produção agrícola do Brasil e do Estado de São Paulo, respectivamente (São Paulo, 2000; Brasil, 2002).

A importância das pastagens também é evidenciada pela extensão de terra ocupada pelas plantas forrageiras, $73 \%$ da área agrícola cultivada no país e $51 \%$ da área agrícola cultivada no Estado de São Paulo (São Paulo, 1997; Brasil, 2002). Da área total de pastagens no Estado de São Paulo, estima-se que $80 \%$ seja ocupada por espécies forrageiras cultivadas (São Paulo, 1997). Em comparação com as pastagens nativas, a introdução de plantas forrageiras cultivadas, no cenário agrícola nacional, permitiu ganhos 
expressivos na taxa de lotação animal e na produtividade dos sistemas de produção animal a pasto (Zoby et al., 1987; Arruda, 1994). No entanto, mesmo com essa melhora, observase que esses empreendimentos comumente operam com baixas produtividades $(\mathrm{kg}$ de carne ou de leite/ha/ano) e rentabilidades.

Corsi et al. (2001a) exemplificaram a baixa produtividade e rentabilidade de sistemas de produção animal a pasto através da análise de dados divulgados pela Secretaria de Agricultura e Abastecimento do Estado de São Paulo (São Paulo, 2000). Os autores encontraram relação linear e negativa entre a proporção de pastagem na unidade de desenvolvimento regional e a respectiva receita. Quando $25 \%$ da área agrícola da unidade de desenvolvimento regional encontrava-se ocupada por pastagens, a receita foi equivalente a 27,1 @/ha/ano (base de cálculo de $\mathrm{R} \$ 40,00 / @$ ). Porém, quando 80\% da área agrícola da unidade de desenvolvimento regional mostrava-se ocupada por pastagens, a receita diminuiu para 6,7 @/ha/ano.

A produtividade e a rentabilidade dos sistemas de produção animal em pastagens podem apresentar resultados mais satisfatórios com a implementação de medidas para melhorar o gerenciamento do empreendimento, em que subentende-se a necessidade de melhorar o manejo do sistema solo-planta-animal segundo uma abordagem sistêmica. Em última análise, tem-se que o sucesso do empreendimento pecuário dependerá do perfeito entendimento das inter-relações entre recursos, atividades e influências externas que compõem e determinam o sistema de produção animal a pasto (Martha Júnior et al., 2002).

Contudo, em face dos sistemas de produção existentes no país, fica claro a necessidade de maior atenção para com o manejo adequado da pastagem e para com a fertilidade do solo, visando assegurar a longevidade de pastagens mais produtivas. Embora - manejo da pastagem represente um dos principais meios para assegurar a sustentabilidade dos sistemas de produção animal a pasto, ainda não se tem informações suficientes sobre o manejo das principais espécies forrageiras cultivadas no país. Além disso, a falta na definição de metas e de um planejamento formal para o manejo da pastagem, na maioria das fazendas, raramente permite que o resultado bioeconômico do empreendimento seja otimizado, em razão do pecuarista não ser capaz de detectar problemas em tempo hábil para a implementação de medidas de manejo efetivas e de relação benefício/custo mais favorável (Martha Júnior et al., 2002).

A importância do componente fertilidade do solo tem origem na natureza química restritiva da maioria dos solos tropicais e no elevado potencial de extração de nutrientes do solo pelas plantas forrageiras (Werner et al., 1996; Macedo, 2000). Dessa maneira, a 
reposição e a manutenção da fertilidade do solo constituem premissas básicas para assegurar a longevidade de pastagens produtivas. O aumento no consumo de fertilizantes em pastagens no país, de 110 mil toneladas em 1990, para 570 mil toneladas em 1999 (Anda, 2000), sinaliza que as pastagens estão, paulatinamente, sendo consideradas culturas de maior valor econômico e, como tal, justificam a utilização de fertilizantes (Martha Júnior \& Vilela, 2002). Contudo, quando a adubação de pastagens em 1999 é expressa por unidade de área, ela indica o uso de apenas $6,3 \mathrm{~kg} / \mathrm{ha}$ de fertilizante (presumivelmente NPK), ou seja, verifica-se que o esforço para melhorar a nutrição e a produtividade da planta forrageira, por meio da adubação, ainda é muito limitado.

Dessa breve discussão, fica evidente que em razão da importância econômica da produção de bovinos a pasto, medidas acertadas no manejo e na adubação de pastagens, visando aumentar a produtividade e a lucratividade dos empreendimentos de pecuária, são de extrema relevância para a economia do país. Consoante com essa idéia, tem sido verificado crescente interesse de técnicos e produtores por sistemas intensivos de pastejo, onde, via de regra, está embutida a necessidade de cuidados para com o manejo da pastagem e para com a reposição e a manutenção da fertilidade do solo.

Atualmente, estima-se que cerca de $16 \%$ dos pecuaristas paulistas já adotam alguma forma de intensificação do sistema de produção (São Paulo, 1997). Geralmente, essa intensificação tem sido traduzida pela utilização de corretivos e de fertilizantes em associação com o pastejo rotacionado. A busca pela intensificação dos sistemas de produção de bovinos em pastagens pode ser explicada, pelo menos em parte, pela estrutura das propriedades rurais no Estado de São Paulo. Como grande parte dessas propriedades encontra-se em terras de elevado custo e possuem área inferior a 35 ha (São Paulo, 1997), é imperativo a intensificação do sistema para proporcionar ganhos na escala de produção e, conseqüentemente, garantir a competitividade desses empreendimentos frentes æ̀s outras alternativas de uso da terra (Corsi \& Martha Júnior, 1998).

A estratégia de intensificação de sistemas de produção animal a pasto, quando adotada com critério, pode ser efetiva no aumento do lucro da atividade de pecuária de corte. Em estudo realizado no Estado de São Paulo, pela Embrapa Pecuária Sudeste (Esteves, 2000), observou-se que o lucro em sistemas extensivos de pecuária de corte foi de apenas $R \$ 33,00 /$ ha/ano; em contrapartida, a intensificação do sistema de produção elevou esse lucro para $R \$ 446,00 /$ ha/ano. Com base nas informações desse trabalho, percebe-se que sem a intensificação no uso de pastagens a atividade de pecuária de corte, 
no Estado de São Paulo pelo menos, dificilmente seria capaz de competir favoravelmente com outras alternativas de uso da terra.

Mais recentemente, a irrigação de pastagens, como estratégia para a intensificação dos sistemas de produção animal a pasto, tem despertado o interesse de técnicos e pecuaristas. O principal objetivo da irrigação de pastagens seria 0 de aumentar a produtividade da planta forrageira, visando incrementar a capacidade de suporte das pastagens e, conseqüentemente, elevar o ganho de peso por unidade de área. Com manejo adequado da pastagem, essa maior produção de forragem ainda poderia favorecer a obtenção de ganhos individuais mais satisfatórios, o que reduziria o tempo para o abate dos animais.

Embora a irrigação do pasto possa determinar o incremento na produtividade da planta e do animal em relação à situações de sequeiro, sabe-se que a técnica é onerosa, sinalizando que os fatores de produção devem ser utilizados da maneira mais eficiente possível (Corsi et al., 2001a). Dessa maneira, em adição ao manejo eficiente da irrigação, o conhecimento mais aprofundado da dinâmica dos nutrientes é necessário, no sentido de aumentar a eficiência bioeconômica do empreendimento. Esse fato reveste-se de importância quando se considera que em pastagens de Panicum maximum adubadas, $60 \%$ dos custos de produção, excluindo-se os valores de compra e venda de animais, foram associados ao uso de corretivos e fertilizantes (Tosi, 1999).

Portanto, estudos sobre o comportamento dos nutrientes no sistema solo-planta, marcadamente daqueles móveis no sistema, como o nitrogênio $(\mathrm{N})$, assumem importância destacada, principalmente se conduzidos em diferentes condições de manejo da pastagem e em épocas distintas do ano. Em outras palavras, o maior conhecimento sobre as transformações e a eficiência de utilização do $\mathrm{N}$ no ecossistema de pastagens forneceria subsídios para minimizar as perdas e os impactos negativos desse elemento sobre 0 ambiente e para maximizar a eficiência de uso dos fertilizantes nitrogenados pelas plantas forrageiras. Conseqüentemente, a lucratividade do empreendimento pecuário baseado na exploração de pastagens adubadas poderia ser incrementada de maneira sustentável.

Ademais, estudos desse tipo poderiam subsidiar, num futuro próximo, o desenvolvimento de modelos simples de apoio àtomada de decisão, permitindo ao técnico e ao pecuarista escolher qual a estratégia de manejo da pastagem e de adubação nitrogenada mais apropriada para a sua situação. Nesse escopo, a utilização do isótopo estável do $\mathrm{N}\left({ }^{15} \mathrm{~N}\right)$ constitui uma importante ferramenta, pois seu uso permite traçar o 
destino do fertilizante marcado no sistema solo-planta e os fluxos de $\mathrm{N}$ de um pool para outro no sistema, sem riscos ao operador e ao ambiente.

O presente trabalho foi estruturado em seis partes principais. A primeira parte (capítulo 2) centrou na revisão de literatura relacionada ao tema da tese, abordando-se, em especial, os tópicos irrigação e manejo (intensidade de desfolha) da pastagem e dinâmica do nitrogênio no sistema solo-planta. Na segunda parte, correspondente aos capítulos 3 e 4 , os trabalhos relacionaram-se à definição de metas de intensidade de desfolha para o capim Tanzânia irrigado no inverno e na primavera/verão, respectivamente. Na terceira parte (capítulo 5), o efeito da intensidade de pastejo sobre a eficiência de uso do $\mathrm{N}$ do fertilizante por pastagem irrigada de capim Tanzânia foi considerado, enquanto que, na quarta parte, o foco passou a ser o efeito do nível de adubação nitrogenada sobre as perdas e sobre a recuperação do $\mathrm{N}$-fertilizante aplicado (capítulos 6, 7 e 8). Na quinta parte (capítulo 9), o efeito da adubação nitrogenada sobre a discriminação do ${ }^{13} \mathrm{C}$ foi considerado. Por fim, na última seção, apresentou-se as conclusões gerais do trabalho. 


\section{REVISÃO DE LITERATURA}

\subsection{0 capim Tanzânia}

A espécie Panicum maximum é originária da África e sua introdução no país é bastante antiga, datando do século XVIII (Aronovich, 1995). Acredita-se que a forrageira era utilizada como cama nos navios negreiros que traziam escravos para o Brasil e se estabeleceu, naturalmente, nos locais onde esses navios eram descarregados (Parsons, 1972). Posteriormente, o vento, os pássaros e as próprias pessoas disseminaram o $P$. maximum em diversas regiões do país (Aronovich, 1995).

Estima-se que a espécie ocupou área superior a seis milhões de hectares no Brasil, sendo a maior parte dessas pastagens representadas pelo capim colonião (Aronovich, 1995). No Estado de São Paulo, o capim colonião chegou a representar cerca de $30 \%$ da área de pastagens (Ghisi et al., 1989).

Durante décadas, o capim colonião foi considerado insuperável em termos de qualidade para a engorda de bovinos no Brasil Central (Corsi, 1988). Segundo esse autor, a elevada capacidade de suporte da pastagem recém-estabelecida era outra vantagem apontada com freqüência pelos pecuaristas. Na revisão de Corsi \& Santos (1995), encontra-se relato de que pastagens de capim colonião apresentavam capacidade de suporte de 5 a 6 UA/ha no período de verão ("águas").

Contudo, o desconhecimento sobre as exigências de manejo da espécie forrageira foi um dos principais determinantes da degradação dessas pastagens (Corsi, 1988). Outro fator importante ligado à degradação das pastagens de $P$. maximum foi a falta de cuidados para com a reposição e a manutenção da fertilidade do solo. O modelo extrativista de exploração de pastagens, bastante comum no país, mostrou-se incapaz de garantir a produtividade, a qualidade e a persistência da espécie, de elevada exigência em fertilidade do solo (Werner et al., 1996; Vilela et al., 2000).

Frente à problemática de manejo inadequado da pastagem e de exploração do capim colonião sem que houvesse a preocupação de se estabelecer um programa de 
correção e adubação do solo, pesquisadores e pecuaristas ligados ao setor passaram a procurar novas opções forrageiras, que se adequassem melhor à oferta ambiental de diferentes regiões do país e ao manejo praticado nas fazendas. Esse período foi caracterizado pela rápida expansão de pastagens de Brachiaria spp. no país.

Apenas na década de 80, com o início dos trabalhos de melhoramento genético de Panicum maximum no país e a conseqüente liberação de novas cultivares, ressurgiu o interesse de técnicos e pecuaristas pela espécie. Além da atração "pelo novo", a demanda por essas forrageiras pode ser justificada pela maior conscientização da importância do manejo da pastagem e da reposição da fertilidade do solo para a sustentabilidade de pastagens de $P$. maximum. Conforme discutido adiante, o volume de resultados de pesquisa disponibilizado nos últimos anos, abordando esses tópicos, suporta essa assertiva. Porém, chama-se a atenção para o fato de que grande parte desses trabalhos foram realizados sem a presença dos animais (experimentos de corte em pequenas parcelas), o que impõem limites à aplicação direta dos resultados gerados pela pesquisa em propriedades comerciais. Nota-se, também, que o interesse pelas novas cultivares de $P$. maximum reflete o desejo dos pecuaristas em intensificar o sistema de produção, quer seja em áreas de pastagens degradadas recuperadas (Costa, 2000), em sistemas integrados de lavoura-pecuária (Vilela et al., 1999) ou em áreas em que se prevê a maior utilização de insumos (Corrêa, 1999; Tosi, 1999).

A cultivar Tanzânia (Tabela 1), lançada no país em 1990 pela Embrapa, tem tido grande aceitação junto a técnicos e produtores. Esse fato, reflete, basicamente, o elevado potencial de produção de forragem dessa gramínea (Jank et al., 1994; Tosi, 1999; Penati, 2002) e a qualidade da forragem, geralmente superior à das braquiárias (Euclides, 1995). Conseqüentemente, observa-se elevadas taxas de lotação e ganhos de peso nessas pastagens quando a fertilidade do solo e o manejo são adequados às exigências da planta.

Em experimentos de pastejo com o capim Tanzânia, com o uso moderado de insumos (até $100 \mathrm{~kg} / \mathrm{ha} / \mathrm{ano}$ de $\mathrm{N}$ ), tem-se observado produtividades de até $620 \mathrm{~kg}$ de ganho de peso/ha/ano (Euclides et al., 1997; 2001; Euclides Filho et al., 1999). Nesses trabalhos, a taxa de lotação e o ganho de peso diário nas águas variaram de 1,4 a 3,2 $\mathrm{UA}^{1} / \mathrm{ha}$ e de 540 a $700 \mathrm{~g} / \mathrm{animal} / \mathrm{dia}$, respectivamente. Na seca, a taxa de lotação oscilou de 1,0 a 1,8 UA/ha, enquanto que o ganho de peso diário variou de 100 a 295 g/animal/dia.

Com adubação mais elevada (200 a $530 \mathrm{~kg} / \mathrm{ha} /$ ano de $\mathrm{N}$ ), as produtividades obtidas em pastagens de capim Tanzânia têm sido superiores a $1.000 \mathrm{~kg}$ de ganho de peso/ha/ano

\footnotetext{
${ }^{1} \mathrm{UA}=$ unidade animal, correspondente a um animal com $450 \mathrm{~kg}$ de peso.
} 
(Corrêa, 1999; Tosi, 1999; Aguiar et al., 2001; 2002a), havendo casos em que 1.670 kg de ganho de peso/ha/ano foram registrados com adubação de $430 \mathrm{~kg} / \mathrm{ha} / \mathrm{ano}$ de $\mathrm{N}$ (Maya, 2003). Nesses trabalhos (Corrêa, 1999; Tosi, 1999; Aguiar et al., 2001; 2002a; Maya, 2003), a taxa de lotação média foi de 6,3 e 2,4 UA/ha nas águas e na seca, respectivamente. Os ganhos de peso médios diários, nesses estudos, foram de 710 g/animal/dia no verão e de $610 \mathrm{~g} / \mathrm{animal} / \mathrm{dia}$ no inverno.

Tabela 1. Características morfológicas do capim Tanzânia.

\begin{tabular}{lc}
\hline \multicolumn{1}{c}{ Variável } & Dado morfológico \\
\hline Altura da planta $(\mathrm{m})$ & 1,2 \\
Largura das folhas $(\mathrm{cm})$ & 2,7 \\
Porte das folhas & decumbente \\
Pilosidade das folhas & ausente \\
Pilosidade dos colmos & ausente \\
Cerosidade dos colmos & ausente \\
Manchas rochas nas espiguetas & muitas \\
\hline
\end{tabular}

Fonte: Jank (1995).

\subsection{Efeito da irrigação sobre a produção da planta forrageira}

O principal objetivo de se elevar a produtividade de forragem é aumentar "o número de refeições na propriedade" e, conseqüentemente, incrementar a quantidade de produto animal obtida por unidade de área. Assim, maiores produtividades de massa seca (MS) de forragem teriam potencial para aumentar a produtividade animal, desde que as perdas devidas ao evento de pastejo não fossem elevadas e que a oferta de forragem ${ }^{2}$ fosse mantida em patamares favoráveis à manutenção do desempenho do animal em níveis satisfatórios às intenções do técnico ou produtor, que dependerão dos objetivos da exploração.

Todavia, o aumento da taxa de lotação animal em pastagens traz um maior risco ao empreendimento pecuário, pois a necessidade de haver uma maior produção de forragem para sustentar uma taxa de lotação animal na propriedade mais elevada fica, paulatinamente, mais dependente das incertas variáveis climáticas, como a quantidade e a distribuição de chuvas. A água é o nutriente mais importante controlando a produtividade

\footnotetext{
${ }^{2}$ A disponibilidade de forragem pode ser definida como a relação entre quantidade de forragem (kg MS) por unidade de peso do animal (kg), podendo ser expressa em $\mathrm{kg} / \mathrm{kg}$ ou em termos percentuais (FGTC, 1992).
} 
das pastagens (Rodrigues \& Rodrigues, 1987; Jarvis et al., 1995). Dessa maneira, variações na água disponível no solo para o crescimento da cultura, principalmente quando as taxas de lotação animal na propriedade são mais elevadas ( $>3 \mathrm{UA} / \mathrm{ha}$ ), determinam maiores oscilações no ganho de peso individual dos animais em pastejo, no retorno econômico da atividade de pecuária e, conseqüentemente, uma maior freqüência e magnitude de perda econômica (Parsch et al., 1997).

Para minimizar os efeitos deletérios do déficit hídrico sobre o acúmulo de forragem, alguns técnicos e pecuaristas têm adotado a irrigação de pastagens. Os benefícios da irrigação seriam observados em razão do aumento da produção de forragem: 1) durante a época seca do ano; 2) no caso de ocorrência de veranicos durante o período das águas; e 3) na transição entre os períodos de seca e de chuvas.

\subsubsection{Irrigação de pastagens durante a época seca do ano}

A escassez de forragem durante a época seca do ano é considerada um dos principais entraves à produtividade da pecuária nacional. Minimizar o déficit hídrico nesse período contribuiria para diminuir a estacionalidade da produção forrageira e, conseqüentemente, determinaria menor oscilação na taxa de lotação animal ao longo do ano.

Estudos realizados com o capim colonião evidenciaram que o uso de irrigação foi capaz de elevar a produtividade de forragem no período seco do ano (Guelfi Filho, 1976; Crespo, 1986). Embora os valores relativos (incremento percentual em relação à testemunha não irrigada) e absolutos (quantidade adicional de MS produzida em relação à testemunha não irrigada) da produção de forragem tenham sido significativamente aumentados pelo uso de irrigação nesses experimentos, a estacionalidade da produção forrageira não foi alterada de maneira sensível. Esse fato indica que outros fatores, que não a água, como a temperatura (Cooper \& Tainton, 1968) e o fotoperíodo (Mannetje \& Pritchard, 1974), também estavam limitando a produção de forragem nessa época do ano.

Embora limitações de temperatura e de fotoperíodo invariavelmente limitem a produção de forragem no inverno, Rassini (2002) mostrou que a irrigação do capim Tanzânia melhorou a distribuição de forragem ao longo do ano. Sem irrigação, a produção de forragem foi de 4,1 t/ha de MS nas estações de outono/inverno (21,1\% da produção anual), enquanto que o uso de irrigação elevou a produção de forragem no período para 11,7 t/ha de MS (34,6\% da produção anual). 
As diferenças na resposta à irrigação nos estudos com o capim colonião e com o capim Tanzânia refletem, pelo menos em parte, a melhor distribuição de forragem ao longo do ano do capim Tanzânia em relação ao capim colonião, conforme se depreende do trabalho de Jank et al. (1994).

A comparação entre estudos de pastejo com o capim Tanzânia também indica efeitos positivos da irrigação durante a época seca. Experimentos realizados em condição de sequeiro, com níveis moderados de nitrogênio (< $100 \mathrm{~kg} / \mathrm{ha} /$ ano de $\mathrm{N}$ ), mostraram que a taxa de lotação durante a seca variou de 1,0 a 1,8 UA/ha (Euclides et al., 1997; 2001; Euclides Filho et al., 1999). Entretanto, em avaliação com o capim Tanzânia irrigado e adubado com níveis elevados de nitrogênio ( $80 \mathrm{~kg} / \mathrm{ha}$ de $\mathrm{N}$ em cada ciclo de pastejo), na seca, a taxa de lotação animal média foi de 3,7 UA/ha (Penati, 2002). Em fazendas comerciais, taxas de lotação da ordem de 3,5 UA/ha, em pastagem de capim Tanzânia, têm sido relatadas (Corsi \& Martha Júnior, 1998).

O trabalho de Maya (2003), também com o capim Tanzânia, não indicou efeitos favoráveis da irrigação na seca sobre a taxa de lotação animal, que foi de 1,9 UA/ha nas condições de sequeiro e de 2,1 UA/ha com o uso de irrigação. Nesse experimento, as adubações nitrogenadas foram feitas apenas durante o período das águas. Todavia, podese inferir que resultados mais positivos da irrigação sobre a produção de forragem durante a época seca do ano e, conseqüentemente, sobre a taxa de lotação animal em pastagens irrigadas, são dependentes da adubação nitrogenada, conforme indicado no trabalho de Vilela et al. (2003).

\subsubsection{Irrigação de pastagens durante o período das águas}

A irrigação durante o verão busca, em essência, minimizar os efeitos adversos de veranicos sobre a produção de forragem. Os trabalhos de Guelfi Filho (1972; 1976) mostraram que o incremento percentual na produção de forragem irrigada na seca pode ser superior, inferior ou similar ao observado para a forragem irrigada durante o verão, porém, a quantidade adicional de forragem ( $\mathrm{kg} / \mathrm{ha}$ de $\mathrm{MS}$ ) produzida no verão é freqüentemente mais elevada do que na seca. Obviamente, em anos com quantidade e distribuição adequadas de chuvas, o efeito da irrigação durante o período das águas tende a ser minimizado ou, até mesmo, inexistente (Maya, 2003; Vilela et al., 2003). 


\subsubsection{Irrigação de pastagens durante a transição dos períodos de seca e de águas}

A irrigação no final da época seca/início do período das chuvas pode favorecer a produção de forragem em razão da temperatura e do fotoperíodo já se mostrarem favoráveis ao crescimento da forrageira nessa ocasião, sendo o crescimento da planta limitado pelo déficit hídrico, quer seja em decorrência de quantidades inadequadas ou de distribuição irregular de chuvas. Mesmo em anos sem déficit hídrico acentuado durante o período das águas, tem-se observado respostas favoráveis à irrigação praticada durante a transição dos períodos de seca e de águas (Aguiar et al., 2002b; Maya, 2003; Vilela et al., 2003). No estudo de Maya (2003), por exemplo, a irrigação no período de 24 de agosto a 03 de novembro permitiu elevar a taxa de lotação de 2,5 UA/ha nas condições de sequeiro para 5,5 UA/ha na área irrigada.

\subsection{Efeito do manejo da desfolha sobre a produção da planta forrageira}

O principal efeito do animal em pastejo sobre a planta forrageira é através da desfolha, a qual é definida em termos de intensidade, freqüência e da época do ano em que é praticada (Harris, 1978). A intensidade de desfolha reflete a proporção de forragem removida pelo corte ou pastejo, sendo usualmente medida pelos valores residuais de massa de forragem, altura ou índice de área foliar $\left(\mathrm{IAF}^{3}\right)$. A freqüência de desfolha diz respeito ao intervalo entre cortes ou pastejos sucessivos, enquanto que a época em que a desfolha é praticada reflete as condições climáticas em que ocorre o crescimento da forrageira e o estádio de desenvolvimento da planta (i.e. vegetativo ou reprodutivo).

As recomendações sobre a freqüência de desfolha a ser praticada em pastagens de $P$. maximum cv. Tanzânia estão bem estabelecidas. O intervalo entre desfolhas sucessivas, em pastagens adubadas com níveis moderados a elevados de insumos (100 a 500 kg/ha/ano de N), deve ser ao redor de 35 dias no verão (Cecato et al., 1994; Santos et al., 1999), sendo desejável que a freqüência de desfolha seja elevada para 28 dias na época de florescimento do capim, em abril/maio (Santos et al., 1999). Essa medida busca controlar o desenvolvimento de hastes.

Por outro lado, existem poucas informações na literatura, provenientes de estudos de pastejo, sobre qual a intensidade de desfolha a ser praticada no capim Tanzânia.

\footnotetext{
${ }^{3}$ O IAF é definido como a área de uma face das folhas em relação à superfície de solo que elas ocupam.
} 
A desfolha leniente raramente maximiza a taxa de crescimento da planta forrageira, pois as folhas novas, mais ativas fotossinteticamente (Leafe \& Parsons, 1981; Parsons et al., 1983; Chacón-Moreno et al., 1995), são usualmente removidas pelo pastejo, já que elas se posicionam no topo da cobertura vegetal (Parsons, 1988; Hodgson, 1990; Parsons \& Chapman, 2000). Além disso, sob pastejos lenientes, observa-se a deterioração da estrutura do pasto, conforme evidenciado pelo aumento na proporção de hastes na pastagem e pela conseqüente redução da relação folha/haste (Canto et al., 2001; Penati, 2002). Com essa estrutura da pastagem, a ingestão de forragem pelos animais em pastejo é prejudicada (Stobbs, 1975; Sollenberger \& Burns, 2001). Com efeito, a partir de um determinado resíduo pós-pastejo (i.e. massa de forragem residual intermediária ao pastejo intenso e leniente) não se detecta benefícios substanciais do aumento da massa de forragem residual de $P$. maximum sobre o consumo e o desempenho dos animais em pastejo (Euclides et al., 1993; Balsalobre, 2002; Penati, 2002). Com resíduos pós-pastejo lenientes, observa-se, também, maiores perdas de forragem e menor capacidade de suporte da pastagem, que determinam desempenho bioeconômico menos satisfatório quando comparados com intensidades de desfolha moderadas (Barioni et al., 2003).

Em situações de desfolhas intensas, as plantas não possuem área foliar residual capaz de fixar carbono (C), via fotossíntese, em quantidades suficientes para sustentar sua demanda fisiológica. Nessas condições, a planta forrageira fica dependente de reservas fisiológicas (Rodrigues \& Rodrigues, 1987; Herling et al., 1995; Lemaire, 1997) até que um mínimo de área foliar, capaz de suprir suas exigências energéticas (fotossíntese), seja reposto. Geralmente, essa situação ocorre com a expansão de uma ou duas folhas, uma vez que as folhas em crescimento, em associação com a folha mais nova totalmente expandida, respondem por cerca de $80 \%$ da fotossíntese total da cobertura vegetal da pastagem (Leafe \& Parsons, 1981; Parsons et al., 1983; Chacón-Moreno et al., 1995).

Dessa maneira, o crescimento da planta forrageira depende da interceptação e da utilização de luz pela cobertura vegetal. A interceptação luminosa encontra-se vinculada à quantidade, distribuição e orientação de folhas no perfil da pastagem, enquanto que a eficiência do processo fotossintético é dependente da atividade fotossintética das folhas e do estádio fisiológico da planta (vegetativo ou reprodutivo; Leafe \& Parsons, 1981; Parsons et al., 1983; Mello, 2002).

O estádio fisiológico das folhas remanescentes é importante para a rebrota da pastagem porque a contribuição de folhas senescentes para o processo fotossintético é pequena quando comparada com a quantidade de $\mathrm{C}$ fixado pelas folhas novas, 
fotossinteticamente mais ativas (Parsons et al., 1983; Chacón-Moreno et al., 1995). A contribuição de hastes/pseudohastes para o processo fotossintético é pequena quando comparada com a quantidade de C fixada pelas folhas (Parsons et al., 1983).

Assim, a quantidade de folhas e a composição morfológica da pastagem (proporção de folhas, hastes e material morto) determinam a velocidade do restabelecimento do crescimento da planta forrageira depois da desfolha (Parsons, 1988; Parsons \& Chapman, 2000). Evitar desfolhas freqüentes e intensas, visando a manutenção de cobertura vegetal adequada, é particularmente importante para pastagens de $P$. maximum (Rodrigues \& Reis, 1995; Santos et al., 1999; Penati, 2002), que concentram maiores proporções de área foliar nas regiões intermediária e superior do dossel (Costa et al., 1992; Favoretto et al., 1995) e, portanto, não são capazes de maximizar a interceptação luminosa logo depois de desfolhas mais intensas, em razão do baixo IAF nas porções inferiores da pastagem (Zimmer, 1999; Mello, 2002).

\subsection{Efeito da fertilidade do solo sobre a produção da planta forrageira}

A planta forrageira, irrigada ou não, necessita, obrigatoriamente, de uma quantidade mínima e balanceada de elementos minerais no solo para atender suas demandas nutricionais. A demanda da planta por nutrientes varia com a época do ano e com o manejo geral da pastagem (espécie forrageira, intensidade e freqüência de desfolha, nível de adubação, etc.). Além disso, como a quantidade de nutrientes extraída do solo pela planta forrageira será maior quanto maior for a produção de forragem (Werner et al., 1996), pastagens irrigadas normalmente têm maior demanda por nutrientes do que pastagens de sequeiro, uma vez que a irrigação geralmente eleva a produtividade do pasto (Guelfi Filho, 1972; 1976; Alvim et al., 1986; Crespo, 1986).

Por outro lado, grande parte das pastagens, no país, encontra-se estabelecida em solos de baixa fertilidade química (latossolos, podzólicos distróficos e/ou álicos, areias quartzozas), isto é, em solos com características restritivas ao crescimento vegetal (acidez elevada e níveis tóxicos de alumínio e de manganês) e/ou com baixa capacidade de fornecer nutrientes para o crescimento da planta forrageira (Macedo, 2000; Martha Júnior \& Vilela, 2002). Em outras palavras, a produção de forragem em solos tropicais, na ausência de uso de corretivos e de fertilizantes, é bastante aquém do potencial de produção das gramíneas tropicais. 


\subsection{0 nitrogênio no ecossistema de pastagens}

A dinâmica do $\mathrm{N}$ no sistema solo-planta tem sido extensivamente estudada nos últimos 50 anos para uma gama de agroecossistemas, em especial para aqueles localizados nas regiões temperadas. Para ecossistemas de pastagens de regiões temperadas, aspectos relacionados às transformações do $\mathrm{N}$ no solo, eficiência de uso do $\mathrm{N}$ do fertilizante, perdas de $\mathrm{N}$ do sistema solo-planta, bem como os potenciais impactos do $\mathrm{N}$ sobre o ambiente já foram abordados em diversos estudos (Prins \& Arnold, 1980; Wilson, 1988; Jarvis et al., 1995; Whitehead, 1995; 2000; Jarvis \& Pain, 1997). Seguramente, os conhecimentos sobre esses tópicos encontram-se em estágio bem mais evoluído nessas regiões em comparação com o nível de informação disponível para ambientes tropicais.

Para sistemas de produção animal em pastagens, nos trópicos, os esforços para compreender melhor a dinâmica do $\mathrm{N}$ no sistema solo-planta passaram a ser mais evidentes a partir da década de 60, quando a natureza altamente responsiva da gramínea tropical às adições de $\mathrm{N}$ ao sistema foi ratificada por diversos estudos (sumarizados, por exemplo, nas revisões de Henzell, 1962 e Vicente-Chandler et al., 1974). Desde essa época, até poucos anos atrás, a pesquisa com pastagens de gramíneas tropicais adubadas com $\mathrm{N}$ tem focado, prioritariamente, no estabelecimento de limites econômicos para o uso do fertilizante nitrogenado e na determinação do provável retorno econômico obtido pelo uso desse insumo (Vicente-Chandler et al., 1974; Salles \& Gonçalves, 1982; Teitzel, 1991; Lugão, 2001). Esse enfoque é importante e plenamente justificado pela necessidade de garantir ao fazendeiro maior produção de forragem e, conseqüentemente, elevada produtividade animal e/ou custos de produção reduzidos, que são fatores necessários para a obtenção de ganhos marginais condizentes com o novo patamar de investimentos em adubação (Martha Júnior \& Vilela, 2002).

Vale lembrar que o aumento na produtividade das pastagens é fator indispensável para atender a crescente demanda por alimentos de elevado valor biológico (carne e leite) pela população mundial, que deverá dobrar nas próximas quatro ou cinco décadas e atingir cerca de 11 bilhões de habitantes (Smil, 1997; Pinstrup-Andersen et al., 1999).

Contudo, a "agricultura moderna"4, baseada na maximização da produção agrícola e minimização dos custos de produção, mas com pouca atenção para com os impactos

\footnotetext{
${ }^{4}$ A revolução verde introduziu novos conceitos em termos de práticas agrícolas, como o controle da genética da planta, o uso de irrigação, de fertilizantes e de produtos químicos (para o controle de pragas, doenças e plantas daninhas), visando maximizar a produtividade das culturas ao menor custo possível. À agricultura valendo-se desses recursos deu-se o nome de "agricultura moderna" (Tilman, 1999).
} 
sobre o ambiente é, atualmente, uma alternativa inviável e inaceitável no mundo globalizado. Essa nova postura tem origem na conscientização de governos e sociedades sobre a importância de preservar o ambiente por meio da redução do impacto ambiental causado pelas atividades agrícolas, em adição à necessidade de maximizar a produção vegetal de maneira econômica (Pinstrup-Andersen et al., 1999; Tilman, 1999).

Dessa maneira, é evidente, nos dias atuais, a necessidade de desenvolver estratégias para assegurar nutrição adequada à planta forrageira e ao animal em pastejo ao mesmo tempo em que se confere proteção aos recursos/qualidade do solo, água e atmosfera (Jarvis, 1998), uma vez que as pastagens, em especial aquelas produtivas, que sustentam elevadas taxas de lotação animal, não são mais consideradas benignas ao ambiente (Scholefield \& Oenema, 1999). Essa assertiva encontra suporte no fato de que sistemas "verticalizados" de produção animal, com elevado uso de insumos, estão, via de regra, associados com uma maior concentração de animais por unidade de área, o que potencialmente predispõe a alterações nos ciclos de nutrientes no ecossistema de pastagem (Aarts et al., 1992; 2000; Velthof \& Oenema, 1997).

Para atender os conflitantes objetivos de maior produtividade/rentabilidade agrícola e de redução do impacto ambiental, o conhecimento e manejo dos elementos minerais, marcadamente do $\mathrm{N}$, nos diferentes agroecossistemas, assumem posição de destaque. Obrigatoriamente, os "pools" (ou reservatórios, ou compartimentos) e as transformações do $\mathrm{N}$ no ecossistema de pastagem precisam ser quantificados e conhecidos, por meio de técnicas capazes de atender as propostas idealizadas. A grande amplitude nas eficiências parciais dos diversos processos inerentes ao ciclo do $\mathrm{N}$, oferece oportunidade para manipulação (Jarvis, 1998) e ratifica a proposta de melhor entendimento da dinâmica do N no ecossistema para garantir elevada rentabilidade ao empreendimento pecuário baseado na exploração de pastagens sem, no entanto, prejudicar o ambiente.

$\mathrm{O}$ ciclo global do $\mathrm{N}$ inclui os subciclos atmosférico, hidrológico, terrestre e aquele presente na biosfera e, numa escala global, o ciclo do $\mathrm{N}^{5}$ é fechado. $\mathrm{O}$ ciclo terrestre do $\mathrm{N}$ é composto pelo sistema solo-planta e, no caso de ecossistemas de pastagens, pelo sistema solo-planta-animal (Floate, 1987; Jarvis et al., 1995; Wedin, 1996). Nos últimos anos, tem sido enfatizada a importância da atmosfera no ciclo terrestre do $\mathrm{N}$, dada a

\footnotetext{
${ }^{5}$ A movimentação do $\mathrm{N}$ através de vários reservatórios é definida como "o ciclo do N". A fase (gasosa, líquida e sólida) e o estado de oxidação (carga elétrica das formas de $N$, que varia de $-3 a+5)$ do $N$ mudam durante a "ciclagem" entre os diferentes "pools", o que torna o ciclo do N particularmente complexo (Delwiche, 1970; Jarvis et al., 1995; Stevenson \& Cole, 1999).
} 
natureza interagente do $\mathrm{N}$ desse componente com o $\mathrm{N}$ dos compartimentos solo e planta (Holtan-Hartwig \& Bockman, 1994; Sharpe \& Harper, 1995; Harper \& Sharpe, 1998).

Em ecossistemas naturais, como florestas e pastagens nativas, assume-se que as perdas de $\mathrm{N}$ são baixas e contrabalançadas por pequenos acréscimos de $\mathrm{N}$ ao sistema ( $\mathrm{N}$ proveniente da atmosfera, reciclagem do $\mathrm{N}$ de resíduos vegetais e de origem animal e mineralização do $\mathrm{N}$ da matéria orgânica do solo), de modo que esses ecossistemas são, de certa forma, de natureza conservativa. A sustentabilidade desses ecossistemas ao longo dos séculos, sem a interferência do homem, dá suporte a essa idéia.

Por outro lado, em ecossistemas modificados (agroecossistemas), o ciclo do $\mathrm{N}$ passa a ser aberto, de natureza não conservativa, e necessita da intervenção do homem no sentido de garantir a sua sustentabilidade (Myers \& Robbins, 1991; Boddey et al., 1996; Wedin, 1996). Em sistemas que operam com baixo nível de manejo/insumo, o $\mathrm{N}$ desempenha papel fundamental na sustentabilidade da comunidade vegetal, enquanto que em sistemas de produção "verticalizados" e de melhor manejo, o N, além de atuar sobre a sustentabilidade da comunidade de plantas, torna-se o principal modulador da produtividade vegetal (Robbins et al., 1989; Myers \& Robbins, 1991; Jarvis et al., 1995; Corsi \& Martha Júnior, 1997).

\subsubsection{Influência do nitrogênio sobre a fisiologia da planta forrageira}

Nos tecidos da planta forrageira, o $\mathrm{N}$ é distribuído em estrutural, metabolicamente ativo e em componentes de reserva. O N estrutural está associado com a parede celular e com os ácidos nucléicos. O N metabolicamente ativo, representado basicamente pelas enzimas, responde prontamente ao aumento no suprimento de $\mathrm{N}$ para a planta, promovendo, potencialmente, incrementos na fotossíntese e, conseqüentemente, no crescimento do vegetal. Quando o suprimento de $\mathrm{N}$ excede as exigências fisiológicas da planta ele é armazenado, usualmente na forma de nitrato $\left(\mathrm{NO}_{3}{ }^{-}\right)$e amidas (Fernandes \& Rossielo, 1986; Whitehead, 1995).

A essencialidade do $\mathrm{N}$ na produtividade da planta forrageira reflete sua influência sobre aspectos morfofisiológicos, em razão da participação desse elemento, por exemplo, na estrutura de proteínas, de clorofila e de carreadores que participam de processos fisiológicos no vegetal. Para $P$. maximum, tem sido bem caracterizado que o aumento da disponibilidade de $\mathrm{N}$ no meio interfere positivamente sobre os fatores que estimulam 0 crescimento acelerado da planta forrageira e, conseqüentemente, concorrem para 0 
aumento da produtividade da pastagem, como a mobilização de reservas ( $\mathrm{C}$ e $\mathrm{N}$ ) na planta depois da desfolha, a expansão da área foliar e o aumento no peso e no número de perfilhos (Wilson, 1975a,b; Corsi, 1984; Mello, 2002; Santos et al., 2002).

Grande parte dos efeitos positivos do N sobre a produção de forragem pode ser explicado pela ação desse elemento sobre o processo fotossintético. Os estudos de Wilson (1975a,b) mostraram que o suprimento de $\mathrm{N}$ interferiu positivamente na capacidade fotossintética da planta e na recuperação da área foliar depois da desfolha. O autor também verificou que o efeito positivo do plano de nutrição nitrogenada sobre essas variáveis foi potencializado por temperaturas elevadas $\left(30\right.$ a $\left.35^{\circ} \mathrm{C}\right)$, que favorecem a atividade fotossintética de plantas com metabolismo fotossintético C4 (Cooper \& Tainton, 1968; Chacón-Moreno et al., 1995; Mello, 2002).

Assim, reconhece-se que a deficiência de qualquer um dos elementos essenciais à planta reduz a sua capacidade fotossintética, porém, esse efeito é particularmente evidente quando ocorre a deficiência de N (Taiz \& Zeiger, 1991; Hopkins, 1995). A dependência da eficiência do processo fotossintético na nutrição nitrogenada da planta reflete a participação do N na estrutura da clorofila, de carreadores "redox" na cadeia de transporte de elétrons da fotossíntese e de todas as enzimas envolvidas no metabolismo do C, como as enzimas fotossintéticas ribulose 1,5-bifosfato carboxilase oxigenase (Rubisco) e fosfoenolpiruvato carboxilase (PEP carboxilase; Taiz \& Zeiger, 1991; Hopkins, 1995). Adicionalmente, o $\mathrm{N}$ atua positivamente sobre a atividade dessas enzimas fotossintéticas e é fator indispensável para a transferência do dióxido de $\mathrm{C}\left(\mathrm{CO}_{2}\right)$ das células da bainha para as células do mesofilo em plantas de metabolismo fotossintético C4 (Meinzer \& Zhu, 1998).

Desse modo, seria particularmente interessante aprimorar os conhecimentos sobre a influência do $\mathrm{N}$ sobre os fluxos de $\mathrm{C}$ em pastagens, que, em última análise, refletirão a capacidade de absorção e de utilização de $\mathrm{CO}_{2}$ pelas plantas. Nesse contexto, 0 fracionamento dos isótopos de $\mathrm{C}^{6}$ que ocorre durante a fotossíntese é uma das técnicas mais úteis na investigação da influência de fatores ambientais e de manejo sobre a eficiência de absorção do $\mathrm{CO}_{2}$ pelas plantas (O'Leary, 1988; Boutton, 1996).

Durante a fotossíntese, as plantas discriminam o isótopo pesado $\left({ }^{13} \mathrm{C}\right)$ em razão de pequenas diferenças em propriedades bioquímicas e físicas ${ }^{7}$ resultantes da diferença na massa dos dois isótopos de C. Essa característica discriminatória dos isótopos de C em

\footnotetext{
${ }^{6} \mathrm{O} \mathrm{CO}_{2}$ da atmosfera é composto pelos isótopos estáveis ${ }^{12} \mathrm{C}(98,9 \%)$ e ${ }^{13} \mathrm{C}(1,1 \%)$.

${ }^{7} \mathrm{~A}$ discriminação entre isótopos de $\mathrm{C}$ ocorre, principalmente, em razão de propriedades bioquímicas das enzimas envolvidas na fixação do $\mathrm{CO}_{2}$ atmosférico pelas plantas (Rubisco e PEP carboxilase) e de limitações àdifusão do $\mathrm{CO}_{2}$ para o interior das folhas.
} 
processos metabólicos, quando expressa em relação ao padrão, permite obter informações sobre a eficiência de absorção do $\mathrm{CO}_{2}$ por plantas submetidas a uma dada condição de ambiente ou de manejo.

$\mathrm{O}$ interesse na determinação da composição isotópica de ${ }^{13} \mathrm{C}$ em plantas submetidas a diferentes condições de ambiente e/ou de manejo centra, então, na possibilidade de pequenas diferenças na concentração isotópica de ${ }^{13} \mathrm{C}$ do material (geralmente de 1 a 4\%) revelar informações sobre processos metabólicos, químicos e físicos. Em plantas $\mathrm{C} 4$, os processos em que o fracionamento é mais significativo são a difusão estomatal e a carboxilação da fosfoenolpiruvato. Para essas plantas, a difusão figura como a etapa mais limitante ao processo fotossintético e ao fracionamento de ${ }^{13} \mathrm{C}$ do que a carboxilação (O'Leary, 1988).

A composição isotópica do material é designada pela letra grega delta minúsculo $(\delta)$, sendo os valores dessa composição expressos na base "por mil" ( $\delta^{13} \mathrm{C}, \% \circ$ ). Plantas

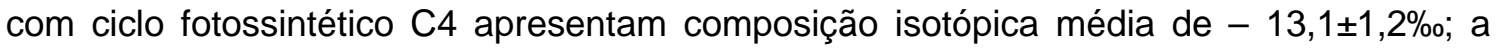
amplitude nos valores de composição isotópica em plantas C4 situa-se na faixa de - 9\% a - 17\% (O’Leary, 1988; Boutton, 1996; Meinzer \& Zhu, 1998; Medina et al., 1999). Um valor mais negativo de $\delta^{13} \mathrm{C}$ significa que na razão ${ }^{13} \mathrm{C} /{ }^{12} \mathrm{C}$ existe mais ${ }^{12} \mathrm{C}$, i.e., o isótopo de massa mais leve. Analogamente, valores mais positivos implicam em maior proporção do isótopo pesado $\left({ }^{13} \mathrm{C}\right)$ na razão ${ }^{13} \mathrm{C} /{ }^{12} \mathrm{C}$. Os valores negativos de $\delta^{13} \mathrm{C}$, na maioria dos materiais naturais, sinaliza que eles apresentam menos ${ }^{13} \mathrm{C}$ do que o padrão.

$\mathrm{O}$ valor de $\delta^{13} \mathrm{C}$ é o resultado da composição isotópica inerente ao próprio material em estudo e da discriminação do isótopo de $C$ em resposta a alterações no ambiente e/ou no manejo. Dessa maneira, é preferível expressar os resultados em termos da discriminação (ou fator de enriquecimento ou fracionamento) do ${ }^{13} \mathrm{C}\left(\Delta^{13} \mathrm{C}\right.$, \%०), que reflete as conseqüências dos processos biológicos (Farquhar et al., 1989). Em outras palavras, o valor de $\Delta^{13} \mathrm{C}$ fornece uma indicação mais direta da magnitude de fracionamento isotópico entre o produto ( $\mathrm{C}$ na planta) e a fonte $\left(\mathrm{CO}_{2}\right.$ atmosférico; Boutton, 1996).

Os valores de $\delta^{13} \mathrm{C}$ e $\Delta^{13} \mathrm{C}$ são inversamente relacionados, i.e., quando o valor de $\Delta^{13} \mathrm{C}$ é maior, o valor de $\delta^{13} \mathrm{C}$ é menor (mais negativo). Alguns poucos estudos realizados com plantas C4 mostraram que, sob condições de estresse (baixa disponibilidade de água, luz ou nitrogênio), os valores de $\Delta^{13} \mathrm{C}$ nas amostras aumentaram, refletindo valores de $\delta^{13} \mathrm{C}$

${ }^{8} \mathrm{O}$ padrão é o $\mathrm{CO}_{2}$ obtido a partir de uma rocha calcária, chamada de PDB ("Pee Dee" formation, na Carolina do Sul, EUA). 
mais negativos (Boutton, 1996; Buchmann et al., 1996; Meinzer \& Zhu, 1998). Esse fato indica limitações ao processo fotossintético.

Todavia, é necessário mais experimentação com plantas C4 para melhor avaliar o efeito de variações em fatores de manejo e de ambiente sobre a discriminação isotópica do ${ }^{13} \mathrm{C}$ (Meinzer \& Zhu, 1998). Estudos de campo, refletindo condições próximas às experimentadas pelas pastagens em fazendas comerciais, são escassos. Para esses agroecossistemas, estudos preliminares poderiam avaliar as respostas das plantas forrageiras em face de uma ampla faixa de suprimento de N. Numa segunda etapa, o efeito do manejo da pastagem sobre os fluxos de $\mathrm{N}$ no sistema também seria um interessante assunto de pesquisa, pois a intensidade e a freqüência de desfolha e a época do ano em que o evento de pastejo ocorre não afetam apenas a fisiologia do crescimento da planta forrageira (item 2.3), mas interferem, também, na exigência da planta por nutrientes.

\subsubsection{Efeito do manejo da pastagem sobre a nutrição nitrogenada da planta forrageira}

Períodos de crescimento mais ativos da pastagem são associados com maiores taxas de absorção de nutrientes (Westerman et al., 1972; Catchpoole et al., 1983; Lemaire, 1997; Martha Júnior, 1999). Como a taxa de acúmulo de forragem é influenciada pela época do ano, pelo resíduo (altura, massa de forragem ou IAF) deixado depois da desfolha e pela freqüência de pastejo (Parsons, 1988; Hodgson, 1990; Martha Júnior, 1999; Santos et al., 1999; Queiroz Neto et al., 2001; Penati, 2002), é pertinente assumir que a variação em qualquer um desses fatores repercutirá em diferentes ritmos de absorção de nutrientes pela planta forrageira.

O efeito da época de desfolha sobre a absorção de $\mathrm{N}$ pela planta forrageira foi ilustrado em diversos estudos com pastagens tropicais (Westerman et al., 1972; Catchpoole et al., 1983; Martha Júnior, 1999; Queiroz Neto et al., 2001). No estudo de Martha Júnior (1999), por exemplo, a quantidade de $\mathrm{N}$ presente na biomassa aérea do capim-elefante, no verão superou a quantidade observada no outono em 2,2 e 1,4 vezes para as adubações com uréia e sulfato de amônio, respectivamente. Na média das duas fontes de $\mathrm{N}$, a produção de forragem, no verão, foi o dobro da verificada no outono, indicando que o crescimento da planta forrageira estava mais ativo na primeira época. Entretanto, o efeito da época de desfolha sobre a absorção de nutrientes pela planta forrageira é alterado pela intensidade e pela freqüência de pastejo. 
Desfolhas intensas prejudicam a absorção de nutrientes pelas raízes, em razão da redução (Harris, 1978; Thornton \& Millard, 1996): 1) nas taxas de transpiração da planta; 2) na mobilização de reservas orgânicas ( $(\mathrm{e}$ e N $)$ de raízes e hastes para a parte aérea; e 3) nos níveis de assimilados na planta. Além disso, reconhece-se que é inevitável a perda de parte do sistema radicular imediatamente depois da desfolha, sendo este efeito proporcional à intensidade e à freqüência do corte ou pastejo (Corsi et al., 2001b). O estudo de Thornton \& Millard (1993), com azevém perene (Lolium perenne), mostrou que a maior severidade de desfolha determinou a diminuição da massa de raízes, fato associado com a redução na absorção de $\mathrm{N}$, que diminui de 0,54 para $0,14 \mathrm{mg} \mathrm{N} /$ semana/planta quando a forrageira foi repetidamente cortada a 8 e a $4 \mathrm{~cm}$, respectivamente.

Por um lado, a perda de raízes imediatamente depois da desfolha representa uma estratégia fisiológica da planta que visa proporcionar uma rápida recuperação da parte aérea (rápida retomada do processo fotossintético) e conseqüente equilíbrio positivo de carbono na planta, através da diminuição da demanda de carbono pelo sistema radicular (Richards, 1993). Por outro lado, esta perda de raízes também implica em menor capacidade de absorção de água e de nutrientes pela planta forrageira. Ademais, pastejos intensos e freqüentes determinam a renovação mais lenta do sistema radicular depois da desfolha (Donaghy \& Fulkerson, 1998; Dawson et al., 2000; Pagotto, 2001), o que reduz ainda mais a capacidade da planta em absorver nutrientes e água do solo.

Paradoxalmente, a rapidez com que a parte aérea se refaz depois da desfolha, bem como o ritmo com que o crescimento de raízes se processa, dependem de uma série de mecanismos fisiológicos da planta forrageira, como a absorção de nutrientes e a mobilização de reservas orgânicas (Richards, 1993; Donaghy \& Fulkerson, 1998; Corsi et al., 2001b).

Chama-se a atenção para o fato de que prejuízos na absorção de N, via sistema radicular, podem ser particularmente importantes para o capim Tanzânia. Resultados obtidos em condições controladas mostraram que o crescimento do capim Tanzânia (planta proveniente de semente) dependeu prioritariamente da absorção do $\mathrm{N}$ do meio, uma vez que menos de $20 \%$ do $\mathrm{N}$ presente na planta, imediatamente depois da desfolha, foi representado por $\mathrm{N}$ de origem endógena (i.e. pela mobilização de reservas nitrogenadas na planta; Santos et al., 2002).

Deste modo, a proposta de Bloom (1994) de que “... a ineficiência na absorção do N do solo deve-se mais a falta de raízes no lugar certo e na hora certa do que a mecanismos inadequados de absorção do nutriente pela planta..." soa como verdadeira, pois conforme 
indicado por Gregory (1994), as plantas parecem apresentar capacidade de absorver quantidade suficiente de $\mathrm{N}$ para atender as suas exigências, desde que as suas raízes estejam presentes em nichos onde o $\mathrm{N}$ se encontre em formas (i.e. $\mathrm{NO}_{3}{ }^{-}$e $\mathrm{NH}_{4}{ }^{+}$) e/ou em disponibilidades adequadas às características do sistema radicular (por exemplo, 0 comprimento específico).

Fica claro, portanto, a importância de se conhecer as diversas formas de entradas e de saídas de $\mathrm{N}$ do sistema solo-planta. Além desses fatores e das interações entre eles, ciclos internos de $\mathrm{N}$ também operam no solo, de maneira que mesmo que ganhos e perdas de $\mathrm{N}$ no sistema estejam em balanço, o $\mathrm{N}$ continua a ciclar no solo (Jarvis et al., 1996). Uma característica principal desse ciclo interno é a renovação biológica do $\mathrm{N}$ através dos processos de mineralização e de imobilização, que, por sua vez, são influenciados pelas quantidades e características qualitativas do $\mathrm{N}$ que entra no sistema, pelas transformações bioquímicas que ocorrem no solo e na interface solo-planta, pela remoção ou pela perda do $\mathrm{N}$ do sistema e pelas interações do ciclo do $\mathrm{N}$ com os outros ciclos de nutrientes.

\subsubsection{Adições de nitrogênio ao sistema solo-planta forrageira}

Embora parte das exigências da planta por $\mathrm{N}$ possa ser suprida pela absorção direta de formas orgânicas de $\mathrm{N}$, como aminoácidos e moléculas de uréia, a quase totalidade dessas exigências é atendida pela absorção de formas minerais de N, i.e., nitrato $\left(\mathrm{NO}_{3}{ }^{-}\right)$e amônio $\left(\mathrm{NH}_{4}{ }^{+}\right.$; Fernandes \& Rossielo, 1986; Whitehead, 1995). Dessa maneira, as exigências da planta são contempladas pelo somatório do $\mathrm{N}$ mineral proveniente da atmosfera, de fertilizantes e de resíduos orgânicos adicionados ao solo. $\mathrm{O} N$ proveniente dos ciclos internos do solo também é importante no fornecimento de $\mathrm{N}$ para a planta (Scholefield et al., 1991; Jarvis et al., 1996). No caso de sistemas de produção animal em pastejo, o $\mathrm{N}$ da excreta do animal também contribui para a nutrição nitrogenada da planta forrageira, porém, de maneira localizada, na área de influência da excreta (Haynes \& Williams, 1993; Corsi \& Martha Júnior, 1997).

\subsubsection{Adições de nitrogênio via atmosfera}

A adição de $\mathrm{N}$ a partir da atmosfera, por meio da deposição seca e úmida, pode auxiliar, ainda que de maneira limitada, no atendimento das exigências nitrogenadas da planta. Em regiões distantes de centros industriais ou de confinamentos de animais, a 
adição de $\mathrm{N}$ a partir da atmosfera é pequena e da ordem de 4 a $8 \mathrm{~kg} / \mathrm{ha} /$ ano de $\mathrm{N}$ (Sanchez, 1976). Nas proximidades de áreas industrializadas e de confinamentos, a contribuição de $\mathrm{N}$ via atmosfera é mais significativa, sendo possível observar valores superiores a $15 \mathrm{~kg} / \mathrm{ha} /$ ano de N (Scholefield et al., 1991; Whitehead, 2000).

A fixação simbiótica do $\mathrm{N}_{2}$ da atmosfera por microorganismos que vivem em simbiose com leguminosas é aspecto bastante conhecido e amplamente discutido na literatura (Taiz \& Zeiger, 1991; Thomas, 1992; 1995; Cadisch et al., 1994; Hopkins, 1995; Whitehead, 1995). A pesquisa também tem indicado que a associação entre gramíneas tropicais e microrganismos livres do solo é capaz de atender parte das exigências nitrogenadas da planta (Miranda \& Boddey, 1987; Boddey et al., 1997; Reis et al., 2001). Contudo, as opiniões sobre as quantidades de $\mathrm{N}$ fixadas por essa via ainda são controversas e limitadas a estimativas provenientes de estudos em laboratório ou em pequenas parcelas. Assim, ainda existe a necessidade de estimar a contribuição da fixação do $\mathrm{N}_{2}$ da atmosfera por associações microorganismos-gramíneas em condições de pastejo (Boddey et al., 1997).

Para o momento, estima-se que, em condições de campo, as contribuições de $\mathrm{N}$ através da fixação não simbiótica representam menos de $15 \mathrm{~kg} / \mathrm{ha} / \mathrm{ano}$ de $\mathrm{N}$ (Whitehead, 1995; 2000; Jenkinson, 2001). Deste modo, essa via de adição de $\mathrm{N}$ ao sistema é geralmente desconsiderada na maioria dos cálculos de balanço de $\mathrm{N}$ em agroecossistemas adubados com N (Shepherd et al., 1996). Para pastagens de gramíneas que não recebem adubações nitrogenadas, a fixação não simbiótica do $\mathrm{N}$ da atmosfera assume caráter de maior relevância, porém, a contribuição do $\mathrm{N}$ proveniente da mineralização da matéria orgânica ainda é quantitativamente mais importante.

\subsubsection{Adições de nitrogênio via fertilizantes}

Gramíneas tropicais, incluindo plantas da espécie Panicum maximum, são altamente responsivas a doses crescentes do fertilizante nitrogenado (Vicente-Chandler et al., 1959; 1962; 1974; Crespo, 1986; Favoreto et al., 1988; 1995; Lugão, 2001; Queiroz Neto et al., 2001). Esses estudos mostraram repostas lineares na produção de forragem para doses de cerca de $400 \mathrm{~kg} / \mathrm{ha} / \mathrm{ano}$ de $\mathrm{N}$.

Expressar a maneira pela qual o $\mathrm{N}$ é utilizado pela planta forrageira, em termos de $\mathrm{kg} \mathrm{MS} / \mathrm{kg} \mathrm{N}$ aplicado é, em última análise, o que interessa ao pecuarista, pois representa a

produção de forragem que poderá ser ofertada ao animal em pastejo. Experimentos 
realizados com diversas cultivares de $P$. maximum mostraram variação de 10 a $90 \mathrm{~kg}$ de $\mathrm{MS} / \mathrm{kg}$ de $\mathrm{N}$ aplicado, refletindo as diferentes condições de solo e de clima dos ambientes de produção, de manejo da planta forrageira (freqüência e intensidade de desfolha) e de cada cultivar de P. maximum (Vicente-Chandler et al., 1959; 1962; Crespo, 1986; Favoreto et al., 1988; 1995; Lugão, 2001; Queiroz Neto et al., 2001). Esses trabalhos também indicaram que para as freqüências de corte ou pastejo normalmente praticadas em $P$. maximum (< 45 dias), considerando adubações de até $400 \mathrm{~kg} / \mathrm{ha} / \mathrm{ano}$, a eficiência de conversão média do $\mathrm{N}$ em MS é de $30 \mathrm{~kg} \mathrm{MS} / \mathrm{kg} \mathrm{N}$ aplicado.

Entretanto, estratégias para maximizar a eficiência de uso do $\mathrm{N}$ só poderão ser delineadas de maneira criteriosa quando a recuperação e as perdas do $\mathrm{N}$ aplicado forem conhecidas. A maior parte dos estudos realizados com pastagens tropicais determinou a recuperação do $\mathrm{N}$ do fertilizante de maneira indireta (ou aparente), isto é, pela diferença do $\mathrm{N}$ absorvido por plantas de parcelas adubadas em relação às plantas de parcelas não adubadas. Para $P$. maximum, os valores de recuperação aparente do $\mathrm{N}$ aplicado têm variado de 23 a 81\%, com média de 40\% (Vicente-Chandler et al., 1959; 1962; Favoretto et al., 1988).

O cálculo da recuperação aparente tem a conveniência de ser de fácil execução e de apresentar baixo custo, pois apenas o teor de $\mathrm{N}$ total na planta, em adição à massa seca de forragem, precisam ser conhecidos. Sua desvantagem diz respeito à incapacidade de distinguir, no $\mathrm{N}$ da planta, o $\mathrm{N}$ derivado do fertilizante daquele proveniente do solo ou da atmosfera. Nesse método, pressupõe-se que os processos fisiológicos das plantas e as transformações do $\mathrm{N}$ e de outros nutrientes no solo são similares nas condições adubadas e não adubadas, o que não é verdade (Jenkinson et al., 1985; Kuzyakov et al., 2000). Dessa maneira, a recuperação aparente do $\mathrm{N}$ é, freqüentemente, uma superestimativa dos valores reais, porque, dentre outros fatores, $\mathrm{O} N$ do fertilizante estimula a atividade biológica do solo e o maior crescimento de raízes das plantas adubadas, fazendo com que o $\mathrm{N}$ de um maior volume de solo seja absorvido por essas plantas (Westerman \& Kurtz, 1974; Hart et al., 1986; Léon et al., 1995; Stout, 1995). Esse fato pode determinar valores de recuperação do N-fertilizante superiores a 100\% (Vitti, 1998).

A recuperação do $\mathrm{N}$ do fertilizante pelas plantas também pode ser determinada pelo método direto (ou isotópico), que se utiliza da técnica do traçador ${ }^{15} \mathrm{~N}$. Nesse método, o $\mathrm{N}$ absorvido pelas plantas é calculado pela quantidade de $\mathrm{N}$ na forragem e pela determinação da razão isotópica do $\mathrm{N}\left({ }^{15} \mathrm{~N} /{ }^{14} \mathrm{~N}\right)$ nas amostras de plantas e do fertilizante marcado aplicado ao solo. Esse método permite distinguir, no $\mathrm{N}$ da planta, a parte que é proveniente 
do fertilizante daquela que vem do solo ou da atmosfera e ainda tem a vantagem de ser mais preciso do que a estimativa de recuperação de $\mathrm{N}$ calculada pelo método aparente (Westerman \& Kurtz, 1974; Rao et al., 1992).

Apesar dos benefícios do uso do traçador- ${ }^{15} \mathrm{~N}$ em estudos sobre a recuperação do $\mathrm{N}$ do fertilizante, apenas um limitado número de experimentos com essa técnica foi realizado com pastagens tropicais, sendo particularmente escassas as pesquisas com fertilizante- ${ }^{15} \mathrm{~N}$ e plantas forrageiras no país. Dos dados levantados na literatura (Tabela 2), observou-se apenas um trabalho com Panicum maximum (Adegbola \& Adepoju, 1983) e, surpreendentemente, nenhum estudo envolvendo o efeito do manejo da pastagem sobre 0 balanço de ${ }^{15} \mathrm{~N}$ no sistema foi contemplado. A recuperação média do fertilizante- $-{ }^{15} \mathrm{~N}$ na parte aérea de pastagens de gramíneas tropicais foi de $30 \%$ do $\mathrm{N}$ aplicado, com amplitude de 6,9 a $69,1 \%$ (Tabela 2). No sistema solo-planta, a recuperação média foi de $73 \%$ (Tabela 2), indicando que a adubação nitrogenada em pastagens deve ser encarada de maneira sistêmica e não compartimentalizada, em que apenas a recuperação na parte aérea é considerada.

Tabela 2. Resumo de 17 experimentos que avaliaram a recuperação do nitrogênio $\left({ }^{15} \mathrm{~N}\right)$ do fertilizante em pastagens tropicais pelo método isotópico.

\begin{tabular}{lcccc}
\hline & \multicolumn{4}{c}{ Recuperação do N $\left({ }^{15} \mathrm{~N}\right)$ do fertilizante (\% do N aplicado) } \\
\cline { 2 - 5 } & Parte aérea & Litter $^{1}$ & Sist.radicular+solo & Sistema solo-planta \\
\hline Média geral & 30,3 & 5,7 & 39,4 & 72,9 \\
Valor mínimo & 6,9 & 2,2 & 15,5 & 28,5 \\
Valor máximo & 61,9 & 10,3 & 72,0 & 98,0 \\
$\mathrm{~N}^{0}$ de observações & 87 & 17 & 59 & 59 \\
\hline
\end{tabular}

Fonte: Bartholomew (1971), Henzell (1971), Westerman et al. (1972), Vallis et al. (1973), Catchpoole (1975), Kissel \& Smith (1978), Adegbola \& Adepoju (1983), Catchpoole et al. (1983), Impithuksa et al. (1984), Impithuksa \& Blue (1985), Mundy \& Mason (1989), Ferreira et al. (1995), Mundy (1995), Martha Júnior (1999), Oliveira (2001), Prasertsak et al. (2001).

Freqüentemente, os valores de recuperação aparente são superiores aos estimados pelo método isotópico (Westerman \& Kurtz, 1974; Rao et al., 1992; Vitti, 1998). Entretanto, não é correto considerar a medida de absorção do fertilizante- ${ }^{15} \mathrm{~N}$ pela planta forrageira como um valor absoluto. Embora o método isotópico seja mais preciso do que o 
método aparente, ele não é, necessariamente, mais exato (Jenkinson et al., 1985; Hart et al., 1986; Rao et al., 1992). Dessa maneira, quando o objetivo da experimentação é simplesmente determinar a recuperação do $\mathrm{N}$ do fertilizante na parte aérea da forragem e há possibilidade de se trabalhar com um tratamento controle (parcelas sem adubação nitrogenada), o método aparente seria mais adequado, em razão dos menores custos de experimentação e da maior praticidade no processo de avaliação e de análise laboratorial. Contudo, quando informações mais detalhadas sobre o movimento e sobre as transformações do $\mathrm{N}$ do fertilizante na planta forrageira e no solo são o objetivo do estudo, e/ou não existe a possibilidade de se trabalhar com um tratamento controle, o método isotópico passa a ser a opção mais interessante.

Para ambos os métodos de estimativa de recuperação do $\mathrm{N}$ aplicado (aparente $\mathrm{e}$ isotópico), pode-se determinar a absorção do $\mathrm{N}$ do fertilizante pela planta por equações de regressão linear (Westerman \& Kurtz, 1974; Hart et al., 1986). Na opção pelo uso de equações, a quantidade de $\mathrm{N}$ na cultura ( $\mathrm{kg} / \mathrm{ha}$ de $\mathrm{N}$; variável dependente) é plotada em relação às doses crescentes do $\mathrm{N}$-fertilizante (variável independente). O coeficiente angular da reta expressa a recuperação média do $\mathrm{N}$ do fertilizante pela planta forrageira para a amplitude de doses de $\mathrm{N}$ testada.

Salienta-se que, independentemente do método usado para estimar a recuperação do $\mathrm{N}$ aplicado, é importante assegurar que não haja movimento lateral do $\mathrm{N}$ do fertilizante ("efeito de bordadura"), uma vez que esse deslocamento é uma fonte potencial de erro em experimentos de campo objetivando determinar a recuperação do $\mathrm{N}$ do fertilizante pelas culturas.

O movimento lateral do $\mathrm{N}$ pode ocorrer por fluxo de massa ou por difusão no solo ou pela translocação do $\mathrm{N}$ nos tecidos da planta. Os processos de fluxo de massa e de difusão são dependentes da disponibilidade de água no solo (Malavolta et al., 1997) e, dessa maneira, é pertinente assumir que durante a estação de pastejo, que coincide com a época das chuvas (outubro a março) no Brasil Central, esses processos estariam mais atuantes do que durante o período seco do ano.

A movimentação lateral do $\mathrm{N}$ do fertilizante, em razão da translocação do $\mathrm{N}$ nos tecidos da planta, irá depender da distribuição lateral do sistema radicular do vegetal que, por sua vez, é afetada por condições de clima, de solo e de manejo da pastagem. Assim, é bem estabelecido que o crescimento da planta forrageira $e$, conseqüentemente, 0 crescimento de raízes, é dependente da luminosidade, da temperatura e da umidade do solo (Cooper \& Tainton, 1968; Mannetje \& Pritchard, 1974; Rodrigues \& Rodrigues, 1987). 
Fatores químicos, como níveis excessivos de alumínio e/ou falta de cálcio no solo (ou de outros nutrientes), restringem o crescimento normal de raízes (Ragland \& Coleman, 1959; Goedert et al., 1985). A compactação do solo, causada pelo pisoteio dos animais em pastejo (Carvalho, 1976; Silva et al., 1997), também pode limitar o crescimento de raízes. O manejo da pastagem, caracterizado por elevada pressão de pastejo e/ou por desfolhas intensas e freqüentes, determina, adicionalmente, prejuízos ao crescimento do sistema radicular (Rodrigues \& Cadima-Zevallos, 1991; Corsi et al., 2001b; Pagotto, 2001).

Apesar da importância da caracterização do sistema radicular e da sua dinâmica em estudos com plantas forrageiras, Scurlock \& Hall (1998) estimaram que menos de $10 \%$ dos experimentos com pastagens consideraram avaliações do sistema radicular. Desses estudos, a maior parte centrou na distribuição vertical do sistema radicular no perfil do solo (Fisher et al., 1994; Kanno et al., 1999; Bertol et al., 2000; Bono et al., 2000), havendo poucos experimentos que buscaram avaliar o sistema radicular de plantas forrageiras quanto àsua distribuição lateral (Georgeson \& Payne, 1897; Adegbola \& Adepoju, 1983).

Georgeson \& Payne (1897), em experimento pioneiro, avaliaram diversas plantas no Kansas (como milheto, sorgo e milho) e encontraram que a distribuição lateral das raízes atingiu distâncias de até $1,8 \mathrm{~m}$. Nesse estudo, o espaçamento entre as plantas (2,4 $\mathrm{m}$ entrelinhas) provavelmente favoreceu essa ampla distribuição do sistema radicular. Dessa maneira, embora interessantes, essas informações têm pouca aplicabilidade na prática. Adegbola \& Adepoju (1983), trabalhando com P. maximum (4 plantas $/ \mathrm{m}^{2}$ ) na Nigéria, encontraram uma distribuição lateral de raízes de cerca de $45 \mathrm{~cm}$, o que poderia indicar que parcelas com área superior a $1 \mathrm{~m}^{2}(1 \mathrm{~m} \times 1 \mathrm{~m})$ seriam suficientes para evitar a translocação lateral do $\mathrm{N}$ entre parcelas adjacentes. Vale lembrar que os estudos de Georgeson \& Payne (1897) e Adegbola \& Adepoju (1983) não consideraram a presença do animal em pastejo e foram realizados com plantas provenientes de sementes, o que dificulta a extrapolação dessas informações para as situações de fazendas comerciais.

Dessa breve discussão, pode-se concluir que o comportamento do $\mathrm{N}$ do fertilizante no solo precisa ser conhecido para permitir que as avaliações sobre adubações nitrogenadas sejam feitas de maneira não tendenciosa (tamanho da parcela adequado) e/ou possibilitem correções quando necessário (Powlson \& Barraclough, 1993). O movimento lateral do $\mathrm{N}$ do fertilizante é particularmente importante quando o traçador- ${ }^{15} \mathrm{~N}$ é utilizado, porque o elevado custo do ${ }^{15} \mathrm{~N}$ encoraja a utilização da menor parcela possível e porque as exigências quanto ao tamanho da parcela não confinada são, em grande parte, determinadas pelo movimento lateral do traçador (Sanchez et al., 1987). 


\subsubsection{Perdas de nitrogênio do sistema solo-pastagem}

As perdas de $\mathrm{N}$ do sistema solo-planta precisam ser conhecidas para permitir que estratégias visando aumentar a eficiência de uso e minimizar o impacto ambiental do $\mathrm{N}$ aplicado sejam delineadas.

As perdas de $\mathrm{N}$ por erosão e por escorrimento superficial em pastagens bem manejadas são pequenas e freqüentemente não ultrapassam 5 kg/ha de $\mathrm{N}$ (Catchpoole, 1975; Spain \& Salinas, 1985; Steele, 1987; Russelle, 1996).

As perdas por lixiviação, conforme indicado pela determinação de ${ }^{15} \mathrm{~N}$ em diferentes profundidades do solo, também não parecem ser motivos de preocupação em pastagens tropicais bem manejadas (Catchpoole, 1975; Kissel \& Smith, 1978; Catchpoole et al., 1983a; Martha Júnior, 1999; Oliveira, 2001; Prasertsak et al., 2001). Esses estudos indicaram que menos de $5 \%$ do $\mathrm{N}$ aplicado é lixiviado para camadas de solo superiores a $30 \mathrm{~cm}$ de profundidade. Cabe ressaltar que a possibilidade de haver absorção do $\mathrm{N}$ do fertilizante até $163 \mathrm{~cm}$ de profundidade do solo (Bartholomew, 1971), dá suporte àidéia de

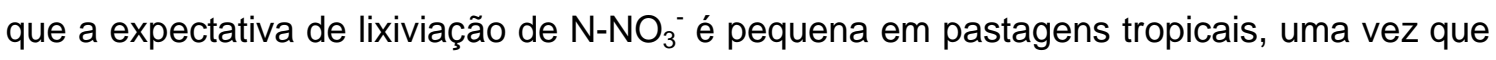
o N "perdido" da camada superficial do solo $(20$ a $30 \mathrm{~cm}$ ) pode ser absorvido pela planta forrageira em maiores profundidades. Ademais, o fato de que os solos utilizados com pastagens (Latossolos e Podzólicos), no país, são profundos e vegetados por plantas forrageiras de elevada capacidade de extração de nutrientes (Martha Júnior \& Vilela, 2002), diminuem, ainda mais, a possibilidade de lixiviação de $\mathrm{N}-\mathrm{NO}_{3}$. Esses fatos sinalizam que os problemas de lixiviação do $\mathrm{N}$ do fertilizante, em solos vegetados por gramíneas tropicais, podem ser ainda menores do que o esperado (i.e. 3 a $5 \%$ do $\mathrm{N}$ aplicado).

Entretanto, a lixiviação de $\mathrm{N}-\mathrm{NO}_{3}{ }^{-}$pode ser problema em regiões que experimentam elevados índices de chuvas e que apresentam uma associação de solos rasos, arenosos, de baixa capacidade de troca catiônica (CTC) e são mal manejados. Nessas situações, as condições de solo e a expectativa de baixa produtividade da planta forrageira e, portanto, de limitada capacidade de remoção de $\mathrm{N}-\mathrm{NO}_{3}{ }^{-}$do solo, estabelecem condições favoráveis à lixiviação do $\mathrm{N}$ do fertilizante (Corsi et al., 2001a).

Com base nessa discussão, deduz-se que, em pastagens de gramíneas tropicais, as perdas mais representativas são aquelas que ocorrem por via gasosa, através da volatilização de $\mathrm{N}^{-\mathrm{NH}_{3}}$ ou da desnitrificação. 


\subsubsection{Perdas de amônia $\left(\mathrm{NH}_{3}\right)$ por volatilização}

O processo de volatilização de $\mathrm{N}^{-\mathrm{NH}_{3}}$ é definido como a transferência de amônia gasosa do solo para a atmosfera. Para que esse processo ocorra, é necessário que haja um suprimento de $\mathrm{N}^{-\mathrm{NH}_{3}}$ próximo àsuperfície do solo. Em pastagens, isso não é problema, pois o íon $\mathrm{NH}_{4}^{+}$, precursor da amônia, é constantemente formado nos solos pela mineralização da matéria orgânica do solo, pela decomposição de resíduos vegetais ou de origem animal, ou pela hidrólise de fertilizantes amídicos e amoniacais. A quantidade de $\mathrm{N}$ $\mathrm{NH}_{3}$ volatilizada, por sua vez, irá depender de fatores de clima, de solo e de manejo, bem como da interação entre eles (Terman, 1979; Freney et al., 1983; Fenn \& Hossner, 1985; Trivelin et al., 1994a).

Fatores de clima, como a umidade relativa do ar, a velocidade do vento e a concentração de amônia na atmosfera podem interferir sobre a volatilização de $\mathrm{N}-\mathrm{NH}_{3}$ (Freney et al., 1983; Bouwmeester et al., 1985; Reynolds \& Wolf, 1987; Harper \& Sharpe, 1995), porém, a temperatura e a precipitação pluviométrica são, normalmente, os fatores climáticos mais importantes nesse processo de perda.

Diversos estudos mostraram que incrementos na temperatura na faixa de 0 a $50^{\circ} \mathrm{C}$ proporcionaram aumentos, geralmente lineares, nas perdas de $\mathrm{N}^{-\mathrm{NH}_{3}}$ por volatilização (Ernst \& Massey, 1960; Hargrove, 1988). Esse efeito pode ser atribuído ao aumento da temperatura, que (Ernst \& Massey, 1960; Freney et al., 1983; Hargrove, 1988; Trivelin et al., 1994a): 1) eleva a proporção de amônia na solução do solo em relação ao íon $\mathrm{NH}_{4}{ }^{+}$, deslocando a reação $\mathrm{NH}_{4}^{+}+\mathrm{OH}^{-} \longleftrightarrow \mathrm{NH}_{3}+\mathrm{H}_{2} \mathrm{O}$ para a direita; 2) diminui a solubilidade da amônia e aumenta a sua difusão; 3) aumenta as taxas de evaporação do solo; e 4) aumenta a atividade da enzima urease.

As chuvas (quantidade e momento em que ocorrem depois da aplicação do fertilizante) são importantes no processo de perda de $\mathrm{N}-\mathrm{NH}_{3}$ por volatilização. Chuvas em quantidades suficientes podem proporcionar a movimentação do adubo para camadas mais profundas do solo, onde o processo de volatilização é sensivelmente reduzido (Ernst \& Massey, 1960; Rodrigues \& Kiehl, 1986; 1992). Chuvas superiores a 10 a $20 \mathrm{~mm}$, imediatamente depois da aplicação superficial do fertilizante, são efetivas na redução das perdas de N-NH 3 por volatilização (Bouwmeester et al., 1985; Black et al., 1987; Denmead et al., 1990). Entretanto, chuvas leves $(<5 \mathrm{~mm})$ ou a ocorrência de orvalho podem permitir a dissolução do adubo, favorecendo a conversão de íons $\mathrm{NH}_{4}{ }^{+}$à $\mathrm{NH}_{3}$, processo que regula o potencial de perda de $\mathrm{N}^{-\mathrm{NH}_{3}}$. Como nessa situação a quantidade de água não é 
suficiente para promover a descida do adubo no perfil do solo, a amônia concentra-se na superfície, aumentando a probabilidade de perda (Harper et al., 1983; Freney et al., 1991; Denmead et al., 1993).

Os fatores de solo mais importantes influenciando as perdas de $\mathrm{N}^{-\mathrm{NH}_{3}}$ por volatilização são o pH, a CTC, o poder tampão e a matéria orgânica do solo (Avnimelech \& Laher, 1977; O’Toole et al., 1985; Fenn \& Hossner, 1985; Haynes, 1986; Trivelin et al., 1994a). O pH é importante por alterar o equilíbrio entre $\mathrm{NH}_{4}{ }^{+}$e $\mathrm{NH}_{3}$ na solução do solo, de maneira que incrementos no $\mathrm{pH}$ deslocam a reação $\mathrm{NH}_{4}^{+}+\mathrm{OH}^{-} \longleftrightarrow \mathrm{NH}_{3}+\mathrm{H}_{2} \mathrm{O}$ para a direita, elevando o potencial de perda. Na região de dissolução do grânulo de uréia, o pH pode elevar-se em até 3 unidades, o que estabelece condições propícias para a volatilização de $\mathrm{N}-\mathrm{NH}_{3}$, inclusive em solos ácidos (Black et al., 1985; Kiehl, 1989; Whitehead \& Raistrick, 1990; Trivelin et al., 1994a; Whitehead, 1995).

Estudos mostraram que para uma dada dose de $\mathrm{N}$-fertilizante (amoniacal ou amídico) aplicada em pastagens, a concentração de $\mathrm{NH}_{4}{ }^{+}$na solução do solo e o pH são influenciados pelo poder tampão e pela CTC do solo (O'Toole et al., 1985; Whitehead, 1995). Em solos de baixo poder tampão e CTC, a taxa de perda de $\mathrm{N}-\mathrm{NH}_{3}$ por volatilização pode ser mantida por um maior período de tempo depois da adubação, enquanto que, em solos de alto poder tampão e CTC, o efeito inverso é esperado (Freney et al., 1983; Fenn \& Hossner, 1985; Haynes, 1986). Adicionalmente, quanto maior a CTC do solo menor será a concentração de $\mathrm{NH}_{4}{ }^{+}$na solução do solo e, portanto, menores perdas por volatilização deverão ocorrer. Estudos realizados por Volk (1959) e Gasser (1964) indicaram que quando a CTC do solo foi inferior a $80 \mathrm{mmol}_{d} / \mathrm{dm}^{3}$ as perdas de $\mathrm{N}-\mathrm{NH}_{3}$ foram elevadas; quando a CTC do solo foi superior a $110 \mathrm{mmol}_{\mathrm{C}} / \mathrm{dm}^{3}$, a volatilização de $\mathrm{N}-\mathrm{NH}_{3}$ passou a ser desprezível. Entretanto, O'Toole et al. (1985) encontraram que o valor de CTC do solo a partir do qual as perdas de $\mathrm{N}-\mathrm{NH}_{3}$ seriam praticamente nulas seria de $268 \mathrm{mmol} / \mathrm{dm}^{3}$.

Em relação à matéria orgânica do solo, seus efeitos são antagônicos. Ao mesmo tempo em que elevados teores contribuem para a maior CTC do solo e, conseqüentemente, para a maior retenção de íons $\mathrm{NH}_{4}{ }^{+}$no complexo de troca, a elevação no teor de matéria orgânica do solo está associada com a maior atividade da enzima urease, determinando maior potencial para o $\mathrm{N}$ proveniente da uréia ser perdido do sistema solo-planta. A presença e a atividade da enzima urease (e de água) são necessárias para que a perda de $\mathrm{N}^{-\mathrm{NH}_{3}}$, a partir do N-uréia, aconteça (Torello \& Wehner, 1983; Reynolds et al., 1985; Haynes, 1986; Reynolds \& Wolf, 1987). Limitações relativas à enzima urease não parecem ser problemas em ecossistemas de pastagens, que apresentam elevada 
quantidade e atividade dessa enzima, tanto no solo como no "litter" presente sobre a superfície do solo (Torello \& Wehner, 1983).

As perdas de $\mathrm{N}-\mathrm{NH}_{3}$ por volatilização a partir de sais amoniacais são devidas a fatores químicos e dependem, principalmente, das propriedades inorgânicas do fertilizante e do solo, como a alcalinidade (Haynes, 1986; Whitehead, 1995). Todavia, o litter, direta ou indiretamente, pode influenciar essas perdas. Em termos indiretos, porque o pH do litter (ou do solo) pode elevar-se ligeiramente em resposta à gutação ou à deposição de orvalho (Harper et al., 1983). De maneira direta, porque a decomposição do litter ${ }^{10}$ promove um pequeno acréscimo no pH do solo (Miyazawa et al., 2000). A elevação do pH, por sua vez, aumenta o potencial de volatilização.

A baixa capacidade de retenção de amônia nos resíduos vegetais presentes na superfície do solo (litter) seria um fator adicional concorrendo para as maiores perdas, enquanto que o efeito desse material sobre a redução no ritmo de evaporação de água do solo teria ação contrária (Freney et al., 1991; Cadish \& Giller, 1997). Dessa maneira, verifica-se que, em algumas situações, o litter interferiu positivamente sobre as perdas de $\mathrm{N}-\mathrm{NH}_{3}$ por volatilização (Hargrove et al., 1987), porém, em outros casos, sua interferência foi muito pequena (Anjos \& Tedesco, 1976).

Outros fatores de manejo que afetam o processo de volatilização de $\mathrm{N}-\mathrm{NH}_{3}$ seriam a fonte, a dose e a localização no solo do fertilizante nitrogenado aplicado. A incorporação da uréia ao solo, a 4 a $5 \mathrm{~cm}$ de profundidade, é efetiva em reduzir as perdas de $\mathrm{N}^{-\mathrm{NH}_{3}}$ por volatilização (Ernst \& Massey, 1960; Rodrigues \& Kiehl, 1986; Hargrove, 1988). Contudo, a incorporação de fertilizantes em pastagens estabelecidas, especialmente naquelas formadas por plantas forrageiras cespitosas, não é recomendada, porque essa prática geralmente prejudica o sistema radicular da planta forrageira e, conseqüentemente, traz prejuízos àsubseqüente rebrota da pastagem (Corsi \& Nussio, 1993).

Para pastagens estabelecidas em solos ácidos, as perdas de $\mathrm{N}-\mathrm{NH}_{3}$ decorrentes da aplicação superficial e a lanço de nitrato de amônio e de sulfato de amônio são geralmente baixas e inferiores a 5 e 10\% do N aplicado, respectivamente (Whitehead \& Raistrick, 1990; Whitehead, 1995; Primavesi et al., 2001). Porém, em algumas situações, essas perdas

\footnotetext{
${ }^{9}$ Nesse texto, o termo litter é definido como o material vegetal destacado da planta (i.e. sem relação funcional com o vegetal) presente sobre a superfície do solo.

${ }^{10}$ Os experimentos que avaliaram as taxas de degradação do litter em pastagens de gramíneas tropicais (relação C:N normalmente na faixa de 70 a 100:1) encontraram que entre 0,08 a 1,02\% do litter existente foi decomposto diariamente (Bruce \& Ebersohn, 1982; Robbins et al., 1989; Thomas \& Asakawa, 1993; Resende et al., 1999). Pastagens manejadas em solos de elevada fertilidade possivelmente terão taxas de degradação do litter mais elevadas, uma vez que operam com relações C:N mais estreitas, da ordem de 30 a 40:1 (Martha Júnior, 1999).
} 
podem ser mais elevadas, da ordem de até $20 \%$ do N-sulfato de amônio aplicado (Martha Júnior, 1999). Em solos alcalinos, a perda de $\mathrm{N}^{-\mathrm{NH}_{3}}$ a partir de sais amoniacais podem atingir patamares de até $40 \%$ do $\mathrm{N}$-total aplicado (Urquiaga et al., 1989; Whitehead \& Raistrick, 1990).

Em relação à uréia, tem-se verificado que as perdas de $\mathrm{N}-\mathrm{NH}_{3}$ por volatilização, como resultado da aplicação superficial e a lanço do fertilizante em pastagens, situam-se, freqüentemente, na faixa de 10 a $25 \%$ do $\mathrm{N}$ aplicado (Catchpoole et al., 1981; Catchpoole et al., 1983; Whitehead \& Raistrick, 1990; Whitehead, 1995; Primavesi et al., 2001). Em condições favoráveis à volatilização - elevada temperatura, ausência de precipitação imediatamente depois da adubação e altas taxas de evaporação de água do solo - as perdas podem atingir até $80 \%$ do N-uréia aplicado (Martha Júnior, 1999).

Chama-se a atenção para o fato de que apesar das elevadas perdas de $\mathrm{N}$-uréia em determinadas situações, a produção de forragem, no curto prazo pelo menos (i.e. durante um ou dois ciclos de pastejo), pode não diferir substancialmente entre plantas adubadas com fontes nítricas, amoniacais ou amídicas (Paulino et al., 1995; Martha Júnior, 1999; Primavesi et al., 2001). Esse fato parece ser conseqüência da capacidade do sistema tamponar o suprimento de $\mathrm{N}$ para a planta forrageira no curto-prazo, conforme orienta o trabalho de Martha Júnior (1999). O estudo de Oliveira (2001) também dá suporte a essa idéia. Entretanto, mais experimentação é necessária para quantificar a extensão desse "efeito tampão" e o período de tempo em que ele pode ser explorado, em diferentes sistemas de produção, sem que hajam prejuízos à sustentabilidade da pastagem.

Quanto à dose do adubo aplicado, tem-se verificado que na grande maioria das vezes, maiores doses do fertilizante resultam em perdas de $\mathrm{N}-\mathrm{NH}_{3}$ por volatilização mais elevadas (Volk, 1959; Black et al., 1985; Primavesi et al., 2001). Porém, uma vez que o padrão de perda pode ser linear ou exponencial, as perdas relativas do fertilizante (porcentagem perdida em relação ao total de $\mathrm{N}$ aplicado) podem diminuir, manterem-se constantes ou aumentarem com os incrementos na dose do fertilizante (Hargrove et al., 1977; Hargrove \& Kissel, 1979; Stumpe et al., 1983; Hargrove, 1988).

Ademais, ressalta-se que a recuperação do $\mathrm{N}$ do fertilizante pode ser maior do que a indicada em experimentos que determinaram as perdas de $\mathrm{N}-\mathrm{NH}_{3}$ por volatilização, uma vez que até $15 \%$ do $\mathrm{N}$ volatilizado do fertilizante nitrogenado aplicado ao solo pode ser absorvido por via foliar (Catchpoole et al., 1983; Sommer et al., 1993; Ping et al., 2000). Os principais fatores que irão interferir na absorção foliar de amônia são o ponto de 
compensação de amônia, a concentração de $\mathrm{N}-\mathrm{NH}_{3}$ na atmosfera, o "status" nitrogenado do vegetal e a área foliar remanescente depois da desfolha.

O ponto de compensação de amônia representa a concentração de $\mathrm{N}-\mathrm{NH}_{3}$ na qual não ocorrem trocas líquidas de amônia entre as plantas e a atmosfera (Farquhar et al., 1980; Harper \& Sharpe, 1995). Quando a concentração de $\mathrm{N}-\mathrm{NH}_{3}$ na atmosfera encontrase abaixo do ponto de compensação, os vegetais irão emitir esse gás para a atmosfera, enquanto que para concentrações de amônia na atmosfera acima do ponto de compensação, as plantas irão absorver esse gás da atmosfera (Farquhar et al., 1980; Holtan-Hartwig \& Bockman, 1994; Harper et al., 1996). O ponto de compensação de amônia varia com a espécie vegetal e com o seu estádio fisiológico, com a temperatura e a hora do dia, com o "status" de N na planta e com o conteúdo de água no solo (Farquhar et al., 1980; Harper et al., 1987; Parton et al., 1988; Holtan-Hartwig \& Bockman, 1994). Normalmente, o ponto de compensação de amônia tem valor semelhante à concentração de $\mathrm{N}-\mathrm{NH}_{3}$ na atmosfera, que, sob condições normais, varia de 1 a $14 \mu \mathrm{g} / \mathrm{m}^{3}$, com valores mais comuns de 1 a $6 \mu \mathrm{g} / \mathrm{m}^{3}$ (Holtan-Hartwig \& Bockman, 1994).

Assim, a elevação na concentração de amônia na atmosfera para níveis substancialmente maiores do que o do ponto de compensação, determina elevado potencial para que parte do $\mathrm{N}-\mathrm{NH}_{3}$ na atmosfera seja absorvida pelas folhas. Tal condição pode ser constatada logo depois da utilização de fertilizantes nitrogenados em pastagens. Harper et al. (1983) observaram que imediatamente depois da aplicação superficial de uréia (94 kg/ha de N-uréia) em pastagem de capim setária (Setaria sphacelata cv. Nandi), a concentração de amônia na atmosfera próxima à superfície do solo elevou-se para níveis de até $1.100 \mu \mathrm{g} / \mathrm{m}^{3}$. Nesse caso, as perdas de $\mathrm{N}-\mathrm{NH}_{3}$ por volatilização foram de $12 \%$ do $\mathrm{N}$ aplicado (Catchpoole et al., 1981).

Em contrapartida, doses maiores do fertilizante nitrogenado normalmente estabelecem maiores teores de N na planta forrageira (Vicente-Chandler et al., 1959; 1962; Crespo, 1986; Whitehead, 1995), o que tende a reduzir a absorção foliar de $\mathrm{N}^{-\mathrm{NH}_{3}}$ em comparação com as situações em que o "status" nitrogenado da planta é menos favorável (Lockyer \& Whitehead, 1986; Whitehead \& Lockyer, 1987). Além disso, para que a absorção foliar de $\mathrm{N}-\mathrm{NH}_{3}$ da atmosfera aconteça é necessário um mínimo de área foliar. 
Conforme se depreende dos trabalhos de Denmead et al. (1993) e Sommer et al. (1993), o aumento da área foliar favorece a absorção de $\mathrm{N}-\mathrm{NH}_{3}$ pela cobertura vegetal ${ }^{11}$.

Entretanto, em pastagens manejadas rotacionalmente, a obtenção de elevado IAF, por ocasião da adubação nitrogenada, que normalmente ocorre imediatamente depois da saída dos animais dos piquetes, pode ser um entrave à absorção da amônia da atmosfera. Estudos recentes com $P$. maximum mostraram que o IAF no início do período de rebrota é normalmente baixo e inferior a 1,0 (Zimmer, 1999; Mello, 2002). Esses valores são explicados pela estrutura aberta da vegetação, que apresenta baixo IAF nas porções inferiores do dossel (Costa et al., 1992; Favoretto et al., 1995) e pequena cobertura do solo pela área basal das touceiras (Penati, 2002).

\subsubsection{Perdas de nitrogênio por desnitrificação}

$\mathrm{O} \mathrm{N}$ pode se perder do sistema solo-planta na forma de óxido nitroso $\left(\mathrm{N}_{2} \mathrm{O}\right)$ ou outras formas oxidadas de $\mathrm{N}\left(\mathrm{NO}_{x}\right)$, como o óxido nítrico $(\mathrm{NO})$, a partir dos processos de nitrificação e desnitrificação.

A nitrificação ocorre em meio aeróbico e, nesse caso, as perdas de óxidos de $\mathrm{N}$ ocorrem de modo mais lento, porém, de maneira contínua (Granli \& Bockman, 1995; Whitehead, 1995; Schlesinger, 1997; Stevenson \& Cole, 1999).

$\mathrm{Na}$ desnitrificação, os microorganismos do solo obtêm do $\mathrm{NO}_{3}{ }^{-}$e do nitrito $\left(\mathrm{NO}_{2}{ }^{-}\right)$a fonte de oxigênio para a respiração, produzindo, nesse processo, os óxidos de $\mathrm{N}$. A desnitrificação ocorre em meio anaeróbico e as perdas de $\mathrm{N}$ na forma de óxidos processam-se de maneira mais intensa e em curtos períodos de tempo (Granli \& Bockman, 1995; Schlesinger, 1997; Stevenson \& Cole, 1999). O processo de desnitrificação também pode ter origem química (quimio-desnitrificação), por meio da reação do nitrito $\left(\mathrm{NO}_{2}{ }^{-}\right)$com a matéria orgânica do solo (Haynes, 1986; Stevenson \& Cole, 1999).

Os principais fatores controlando a desnitrificação são a disponibilidade de $\mathrm{N}\left(\mathrm{NO}_{3}{ }^{-}\right.$ e $\mathrm{NO}_{2}{ }^{-}$) e de $\mathrm{C}$ (fonte de energia para os processos microbianos) em ambiente anaeróbico, o que predispõem as pastagens a elevadas perdas, uma vez que esses ecossistemas normalmente apresentam essas características (Haynes \& Williams, 1993; Granli \& Bockman, 1995; Corsi \& Martha Júnior, 1997).

${ }^{11} \mathrm{O}$ aumento do IAF promove incrementos na absorção foliar de amônia porque a absorção foliar desse gás ocorre através dos estômatos (Farquhar et al., 1980; Sommer et al., 1993; Holtan-Hartwig \& Bockman, 1994). 
A desnitrificação depende de interações complexas entre fatores de clima, de solo e de manejo, que influenciam os processos microbiológicos. Valores de pH próximos à neutralidade favorecem os processos de desnitrificação e nitrificação (Granli \& Brockman, 1995; Stevenson \& Cole, 1999). Condições de temperaturas elevadas e alto teor de umidade no solo (chuvas ou condições precárias de drenagem no solo) também atuam positivamente sobre a desnitrificação (Linn \& Doran, 1984; Bockman \& Olfs, 1998; Oenema et al., 1998), sendo esses fatores as principais explicações para as maiores taxas de emissão de óxidos de $\mathrm{N}$ em regiões tropicais em comparação com as regiões temperadas (Granli \& Brockman, 1995).

Em relação aos fatores de manejo, destacam-se o uso de fertilizantes nitrogenados e de irrigação. O aumento no suprimento de $\mathrm{N}$ no sistema determina maiores emissões de óxidos de N (Granli \& Brockman, 1995; Velthof \& Oenema, 1997; Veldkamp et al., 1998). Em estudo realizado na Costa Rica, com pastagem de Brachiaria brizantha adubada com $300 \mathrm{~kg} / \mathrm{ha} / \mathrm{ano}$ de $\mathrm{N}$, Veldkamp et al. (1998) observaram que 6,8\% do $\mathrm{N}$ aplicado foi perdido por desnitrificação. Esse valor foi 9,6 vezes superior à situação em que a pastagem não recebeu adubação.

Velthof \& Oenema (1997), em trabalho realizado na Holanda com pastagem adubada com $\mathrm{N}$, encontraram emissão de $1 \mathrm{~g} \mathrm{~N}-\mathrm{N}_{2} \mathrm{O} / \mathrm{kg}$ de $\mathrm{MS}$. Com base nessa relação, calcula-se que para uma adubação com $300 \mathrm{~kg} / \mathrm{ha} / \mathrm{ano}$ de $\mathrm{N}$, a expectativa de emissão de $\mathrm{N}_{2} \mathrm{O}$ seria de $3 \%$ do $\mathrm{N}$ aplicado quando a conversão do $\mathrm{N}$-fertilizante em forragem fosse de $30 \mathrm{~kg} \mathrm{MS} / \mathrm{kg} \mathrm{N}\left(9 \mathrm{~kg} \mathrm{~N} \mathrm{~N}_{2} \mathrm{O} / 300 \mathrm{~kg} \mathrm{~N}\right)$. A diferença nos valores encontrados por Veldkamp et al. (1998), em relação às estimativas baseadas no trabalho de Velthof \& Oenema (1997), de 2,3 vezes (6,8\%/3,0\%), encontra suporte no trabalho de Granli \& Brockman (1995). Esses autores indicaram que as emissões de óxidos de $\mathrm{N}$ nos trópicos superaram aquelas verificadas em regiões temperadas em aproximadamente duas vezes.

Todavia, no trabalho de Presertsak et al. (2001), foi estimado que as perdas por desnitrificação contabilizaram $20 \%$ do $\mathrm{N}$ aplicado. Valores de magnitude ainda maior podem ser derivados dos estudos de Catchpoole et al. (1983) e Martha Júnior (1999). As diferenças e dificuldades dos métodos e protocolos de avaliação de desnitrificação (Whitehead, 1995; Jarvis et al., 1995; Oenema \& Bussink, 1999), bem com as condições ecológicas específicas de cada experimento, explicam os resultados inconsistentes entre os experimentos.

No Brasil, a irrigação de pastagens é muitas vezes feita sem acompanhamento técnico, sendo normalmente baseada em práticas geradas na fazenda que não foram 
devidamente validadas pela pesquisa (Corsi et al., 2001a). Entretanto, o manejo da irrigação tem importância sobre o processo de desnitrificação, uma vez que a água adicionada ao sistema pode determinar condições de anaerobiose. Além disso, a combinação de alta umidade no solo e de elevada taxa de lotação animal oferecem condições favoráveis para a compactação, que, por sua vez, atua adversamente sobre o espaço poroso do solo (Silva et al., 1997).

A associação de aplicação excessiva de água via irrigação, elevada taxa de lotação animal e alta disponibilidade de $\mathrm{N}$ no sistema (fertilizantes, excreta do animal e/ou mineralização da matéria orgânica do solo), na presença de altas temperaturas (ambiente tropical), estabelece ambiente favorável para a ocorrência de taxas expressivas de desnitrificação em pastagens tropicais irrigadas e manejadas intensivamente.

Pela revisão apresentada, observa-se a carência de estudos de pastejo visando a definição de metas para o manejo da pastagem, componente-chave dos sistemas de produção animal a pasto. Percebe-se, ainda, que o tema "nitrogênio em pastagens" é assunto complexo e de caráter multidisciplinar, em razão das diversas formas de entradas e de saídas de $\mathrm{N}$ do sistema e dos diferentes "pools" e transformações do elemento no ecossistema. Nesse contexto, fica estabelecida a necessidade de mais esforços para aprimorar o conhecimento e o manejo de pastagens adubadas com fertilizantes nitrogenados, no sentido de possibilitar a adoção de práticas que garantam elevadas produtividades, de maneira econômica, e que, ao mesmo tempo, preservem os recursos e a qualidade do solo, da água e do ar. Com esse pensamento, os trabalhos apresentados a seguir foram desenvolvidos. 


\section{EFEITO DA INTENSIDADE DE DESFOLHA SOBRE A PRODUÇÃO DE FORRAGEM DO CAPIM TANZÂNIA IRRIGADO DURANTE O INVERNO}

\section{Resumo}

A irrigação de pastagens pode amenizar o déficit de forragem durante a época seca do ano. Entretanto, poucos trabalhos foram realizados no país com o objetivo de determinar o manejo de espécies forrageiras nessas condições. O presente trabalho, seguindo um delineamento inteiramente casualizado com cinco repetições, avaliou o efeito de resíduos pós-pastejo (816, 2.548 e $3.113 \mathrm{~kg} / \mathrm{ha}$ de massa seca verde) sobre os componentes da produção forrageira de Panicum maximum cv. Tanzânia irrigado durante o inverno. A massa seca total da pastagem, a massa seca verde da pastagem (folhas+hastes) e a massa seca de hastes cresceram exponencialmente $(P<0,05)$ com 0 aumento na massa do resíduo pós-pastejo. A massa seca de folhas e a relação folha/haste responderam de maneira quadrática ao resíduo pós-pastejo $(P<0,05)$, enquanto que a quantidade de material morto não foi afetada pelo massa de forragem residual $(P>0,05)$. $O$ resíduo pós-pastejo para o capim Tanzânia irrigado e adubado com nitrogênio $(80 \mathrm{~kg} / \mathrm{ha}$ de $\mathrm{N}$ em cada ciclo de pastejo), no período de inverno, considerando ciclo de pastejo de 36 dias, deve ser de 1.900 a $2.100 \mathrm{~kg} / \mathrm{ha}$ de massa seca verde. Esse manejo assegurou a maximização da produção de folhas e da relação folha/haste.

\section{EFFECT OF GRAZING INTENSITY ON HERBAGE PRODUCTION OF IRRIGATED TANZANIA GRASS PASTURE DURING THE WINTER}

Summary

Pasture irrigation can alleviate herbage scarcity during the dry season of the year. However, few studies were carried out in the country aiming to determine the management 
of forage species under these conditions. The present study evaluated the effect of postgrazing residues $(816,2548$ and $3113 \mathrm{~kg} / \mathrm{ha}$ of green dry matter) on herbage production of irrigated Tanzania grass pasture during the winter, using a complete random design with five replicates. Total herbage dry mass, green herbage dry mass (leaves+stems) and stem dry mass exponentially increased $(P<0,05)$ with increasing residual stubble mass. Leaf dry mass and leaf/stem ratio quadratically responded $(P<0,05)$ to post-grazing residues, while the quantity of dead material in the pasture was not affected by residual stubble mass $(\mathrm{P}>0,05)$. The post-grazing residue for irrigated, $\mathrm{N}$-fertilized $(80 \mathrm{~kg} \mathrm{~N} / \mathrm{ha}$ in each grazing cycle) Tanzania grass pasture during the winter, considering a 36-day grazing cycle, should be around 1900 to $2100 \mathrm{~kg} / \mathrm{ha}$ of green dry matter. This management ensured maximum leaf production and leaf/stem ratio.

\subsection{Introdução}

Práticas de manejo que possibilitem o aumento na massa de forragem na seca determinam, potencialmente, maior taxa de lotação animal na época do ano em que a quantidade reduzida de alimento constitui um dos principais obstáculos ao incremento da produtividade da pecuária nacional.

Tem sido demonstrado que o uso de irrigação em pastagens de Panicum maximum cv. Tanzânia pode alterar a estacionalidade da produção forrageira e a taxa de lotação animal na seca, em razão do aumento na produção de forragem na área irrigada em comparação com as situações de sequeiro. Rassini (2002) mostrou que sem a utilização de irrigação, a produção de forragem do capim Tanzânia foi de 4,1 t/ha de massa seca (MS) nas estações de outono/inverno ( $21,1 \%$ da produção anual), enquanto que o uso de irrigação elevou a produção de forragem no período para 11,7 t/ha de MS $(34,6 \%$ da produção anual). Estudos de pastejo com o capim Tanzânia, em condições de sequeiro e com o uso moderado de adubação (< $100 \mathrm{~kg} / \mathrm{ha} / \mathrm{ano}$ de $\mathrm{N}$ ), indicaram que, durante a seca, foi possível obter taxas de lotação de 1,2 a 1,8 unidades animais por hectare (UA/ha; Euclides et al., 1997; 2001). Entretanto, em avaliação com o capim Tanzânia irrigado e adubado com níveis elevados de nitrogênio ( $80 \mathrm{~kg} / \mathrm{ha}$ de $\mathrm{N}$ em cada ciclo de pastejo), a taxa de lotação animal média, na seca, foi de 3,7 UA/ha (Penati, 2002).

Em face do potencial de aumento na produção de forragem e da taxa de lotação animal na seca, informações sobre o manejo de pastagens irrigadas, nessa época do ano, são de interesse, uma vez que o manejo influencia a produção e a utilização de forragem. 
Contudo, poucos trabalhos foram desenvolvidos para solucionar questões de manejo da pastagem nessa época do ano, como, por exemplo, em relação à intensidade de desfolha.

Evitar desfolhas intensas é particularmente importante em pastagens de $P$. maximum, que concentram maiores proporções de área foliar nas regiões intermediária e superior da cobertura vegetal (Costa et al., 1992; Penati, 2002). Desse modo, essas plantas não são capazes de maximizar a interceptação luminosa depois de desfolhas muito intensas, em razão do baixo índice de área foliar, geralmente inferior a 1,0, observado nessas condições (Zimmer, 1999; Mello, 2002). Ademais, quando a desfolha é intensa, verifica-se a redução no crescimento de raízes e no nível de reservas fisiológicas na planta (Gomide et al., 1979; Pagotto, 2001), condições que determinam rebrota mais lenta da pastagem. A eliminação de meristemas apicais, comum em desfolhas intensas, seria mais um fator prejudicando o rápido restabelecimento da planta logo depois do pastejo, porque a rebrota proveniente da emissão de novos perfilhos é mais lenta do que aquela a partir de meristemas remanescentes (Gomide et al., 1979).

No outro extremo, em situações de desfolhas lenientes, o acúmulo líquido de forragem também não é maximizado, em razão das altas taxas de senescência da pastagem (Parsons \& Chapman, 2000). A alteração da estrutura da pastagem em pastejos lenientes, que passa a ser composta predominantemente por hastes, resulta na redução da qualidade da forragem em oferta e pode dificultar o processo de apreensão de forragem pelo animal em pastejo (Stobbs, 1975; Sollenberger \& Burns, 2001).

Canto et al. (2001), trabalhando com o capim Tanzânia manejado sob lotação contínua, no período de julho a setembro, sem o uso de irrigação, sugeriram que alturas de 40 a $60 \mathrm{~cm}$ seriam adequadas para essa forrageira. Cecato et al. (2000), em estudo realizado no período de junho a agosto, também sem irrigação, não encontraram diferenças na produção de forragem do capim Tanzânia quando o corte foi realizado a 20 a ou $40 \mathrm{~cm}$ de altura. Os autores concluíram que a forrageira poderia ser manejada de modo mais intenso sem que houvesse prejuízo na produção de forragem. Experimento realizado por Penati (2002), durante o período de 30/10/99 a 03/01/01, envolvendo três massas de forragem residuais - 1.266, 2.915 e $4.256 \mathrm{~kg} / \mathrm{ha}$ de massa seca verde (MSV) -, em capim Tanzânia irrigado, mostrou que o resíduo intermediário teve melhor resposta em termos de produção de forragem e de desempenho animal do que o pastejo intenso ou o leniente. Porém, a análise estatística no trabalho de Penati (2002), baseada na comparação de médias, não permitiu conhecer o comportamento quantitativo dos componentes da produção de forragem nas amplitudes de massa de forragem residual testadas. 
O presente trabalho, realizado concomitantemente ao estudo de Penati (2002), apresenta a resposta quantitativa dos componentes da produção de forragem (folha, haste e material morto) de pastagem irrigada de $P$. maximum cv. Tanzânia no período de inverno, em face de variações na intensidade de desfolha.

\subsection{Material e Métodos}

O experimento foi realizado em pastagem irrigada de $P$. maximum cv. Tanzânia, em área experimental da Escola Superior de Agricultura "Luiz de Queiroz", Universidade de

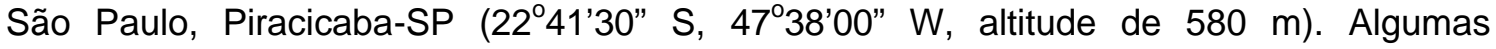
características do clima, durante o período experimental, são apresentadas na Figura 1.

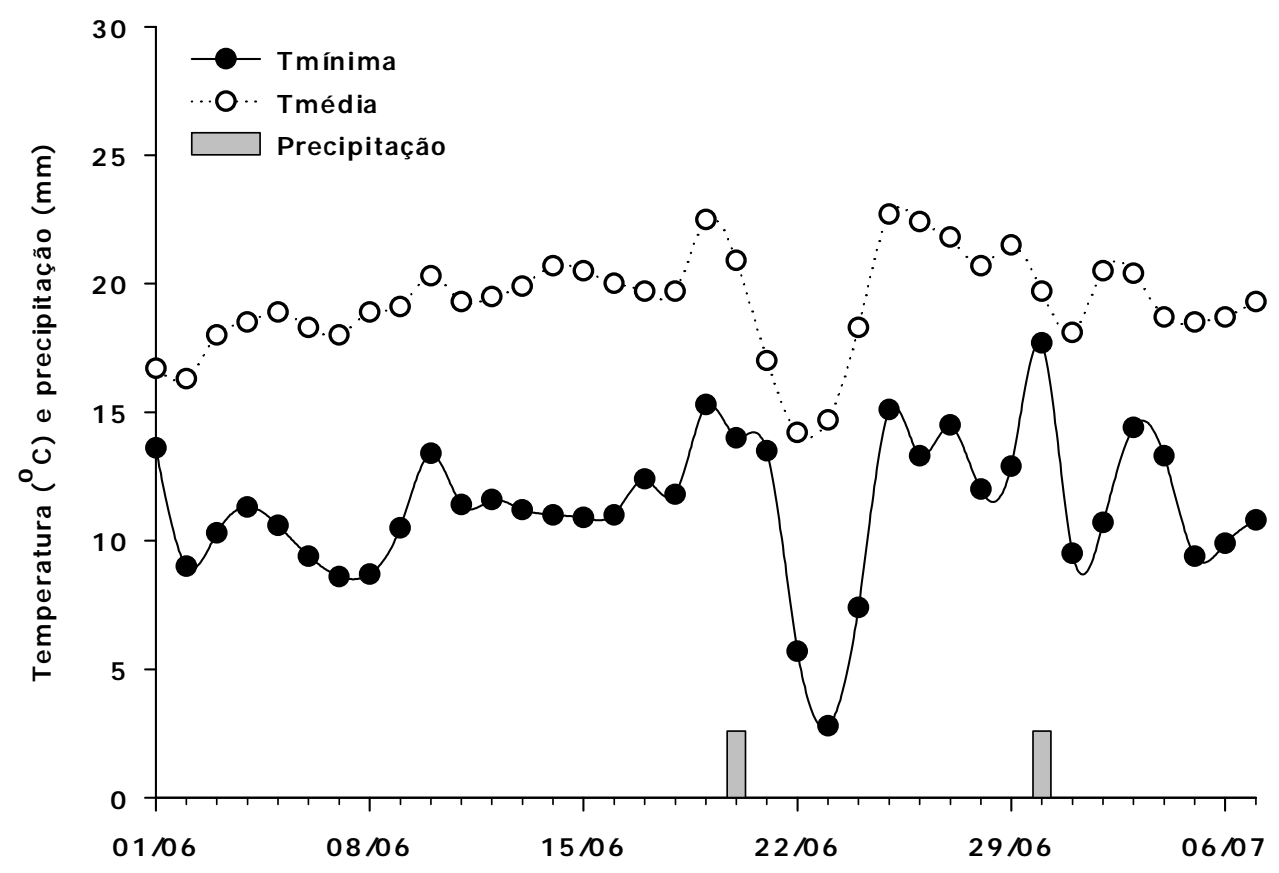

Figura 1 - Temperaturas mínima e média e precipitação pluvial durante o período experimental de inverno (02/06/2000 a 07/07/2000).

A irrigação foi feita por pivô central, visando atingir a capacidade de campo quando tensiômetros instalados na profundidade de $20 \mathrm{~cm}$ indicaram potencial de água no solo de $-30 \mathrm{a}-40 \mathrm{kPa}$ (Lourenço \& Coelho, 2000). 
O solo da área experimental, classificado como Podzólico Vermelho-escuro (Argissolo vermelho) de textura argilosa, apresentava as seguintes características químicas: matéria orgânica $=25 \mathrm{~g} / \mathrm{kg} ; \mathrm{pH}$ em $\mathrm{CaCl}_{2}=5,1 ; \mathrm{P}$ (resina) $=19 \mathrm{mg} / \mathrm{dm}^{3}$; e K, Ca, $\mathrm{Mg}$ e $\mathrm{H}+\mathrm{Al}=4,2 ; 40,8 ; 20,9$ e 38,0 mmolc $/ \mathrm{dm}^{3}$, respectivamente. A correção e adubação do solo seguiram as recomendações de Corsi \& Nussio (1993), visando elevar a saturação por bases para $70 \%$ e o teor de fósforo (resina) e a proporção de potássio no solo para 20 $\mathrm{mg} / \mathrm{dm}^{3}$ e 4 a $5 \%$ da CTC, respectivamente. Detalhes adicionais da área experimental podem ser encontrados em Penati (2002).

O estudo foi realizado no ciclo de pastejo correspondente ao período de 2 de junho a 7 de julho de 2000. O delineamento experimental foi o inteiramente casualizado com cinco repetições. Os tratamentos foram três intensidades de pastejo, com metas para massa de forragem residual de 1.000, 2.500 e $4.000 \mathrm{~kg} / \mathrm{ha}$ de MSV no resíduo pós-pastejo. Entretanto, os valores efetivamente observados foram de $816,2.548$ e $3.113 \mathrm{~kg} / \mathrm{ha}$ de MSV, respectivamente. As alturas pós-pastejo correspondentes a essas massas de forragem residuais foram de 13, 26 e $33 \mathrm{~cm}$, respectivamente (Penati, 2002). O ciclo de pastejo foi de 36 dias, sendo três dias de ocupação e 33 dias de descanso. O pastejo foi feito por machos nelores castrados, de cerca de 16 meses de idade.

Unidades amostrais de $2 \mathrm{~m} \times 2 \mathrm{~m}$ (uma por repetição), apresentando uma touceira do capim em seu centro geométrico, foram locadas aleatoriamente em cada piquete (1.333 $\mathrm{m}^{2}$ ) da pastagem, consoante com os resíduos pós-pastejo sorteados e distribuídos previamente na área. A forragem foi cortada depois de 30 dias da saída dos animais do piquete. O corte para a amostragem de forragem foi feito ao nível do solo. A forragem colhida foi pesada e teve a sua massa seca determinada em estufa com ventilação forçada de $\operatorname{ar}\left(60^{\circ} \mathrm{C}\right.$ por $\left.72 \mathrm{~h}\right) . \mathrm{O}$ valor resultante correspondeu à massa de forragem da pastagem (MFP, kg/ha de massa seca). Uma subamostra do material proveniente da touceira central de cada parcela foi separada em folhas verdes (lâminas foliares), hastes verdes (caule+bainha) e material morto (folhas e hastes senescidas), sendo determinada a massa seca desses componentes em estufa com ventilação forçada de ar $\left(60^{\circ} \mathrm{C}\right.$ por $\left.72 \mathrm{~h}\right)$. $\mathrm{O}$ material verde foi aquele com menos de $50 \%$ de tecido senescente. A proporção de folha, haste e material morto, multiplicada pela MFP, correspondeu à massa de forragem de folhas (MFF), hastes (MFH) e material morto (MFM), expressas em $\mathrm{kg} / \mathrm{ha}$ de massa seca. A soma de MFF e MFH representou a massa de forragem verde da pastagem (MFVP). A razão entre os valores de MFF e MFH indicou a relação folha/haste $(F / H)$ da pastagem. 
A análise dos resultados considerou os resíduos pós-pastejo observados. Os dados foram testados quanto à homogeneidade de variância e normalidade dos erros e a análise de variância e as equações de regressão foram feitas utilizando-se os recursos do pacote estatístico SAS System (SAS, 1989).

\subsection{Resultados e Discussão}

Verificou-se que o resíduo pós-pastejo teve efeito significativo sobre a variável MFF $(P<0,05$; Tabela 1). Pela equação de massa seca de folhas apresentada na Tabela 1 , observa-se que a quantidade de folhas teve resposta quadrática em relação à massa de forragem residual, sendo o valor máximo da curva de resposta de 2,26 t/ha. Essa massa de forragem foi associada ao resíduo pós-pastejo de $2.120 \mathrm{~kg} / \mathrm{ha}$ de MSV.

Canto et al. (2001) também observaram incrementos quadráticos na massa seca de folhas do capim Tanzânia no período de inverno, sendo o valor máximo, de 1 t/ha, constatada na altura de $61 \mathrm{~cm}$. No estudo de Cecato et al. (2000), envolvendo duas alturas de corte (20 e $40 \mathrm{~cm}$ ), no período de junho a agosto, verificou-se produção média de 3,53 t/ha de massa seca de folhas em 70 dias de rebrota, não sendo observado efeito da altura do resíduo sobre a produção de folhas. Considerando uma taxa de acúmulo de folhas relativamente uniforme no estudo de Cecato et al. (2000), calcula-se que a produção de folhas, em 30 dias de rebrota, seria de 1,5 t/ha.

A MFH aumentou exponencialmente com a massa de forragem residual $(P<0,05$; Tabela 1). Tomando como referência o resíduo pós-pastejo de $816 \mathrm{~kg} / \mathrm{ha}$ de MSV, calculase, pela equação de massa seca de hastes apresentada na Tabela 1, que a taxa de aumento da variável MFH dobrou na massa de forragem residual de $1.329 \mathrm{~kg} / \mathrm{ha}$ de MSV. $\mathrm{Na}$ amplitude de resíduos pós-pastejo avaliados (i.e. até $3.113 \mathrm{~kg} / \mathrm{ha}$ de MSV), o incremento da MFH foi de 9 vezes, considerando o mesmo referencial. Esse comportamento possivelmente reflete a presença de perfilhos de idade fisiológica mais avançada e, portanto, mais pesados, em pastagens manejadas sob regime de desfolha leniente (Santos, 2002). Ademais, o aumento na MFH, em razão do incremento no resíduo pós-pastejo, também pode traduzir a maior proporção de perfilhos reprodutivos remanescentes, que são mais pesados do que os perfilhos vegetativos (Korte et al., 1984).

Os resultados observados na massa seca de hastes, no presente trabalho, contrastam com aqueles observados por Canto et al. (2001), em que houve aumento linear na massa de hastes, em razão do incremento na altura da pastagem. Esses autores 
encontraram que a massa seca de hastes, na maior altura estudada $(71 \mathrm{~cm})$, foi de 925 $\mathrm{kg} / \mathrm{ha}$, valor inferior aos indicados na Tabela 1.

Tabela 1. Valores médios e respostas dos componentes da produção de forragem do capim Tanzânia irrigado, no período de inverno, em relação à massa de forragem residual.

\begin{tabular}{|c|c|c|c|c|c|c|}
\hline Resíduo ${ }^{1}$ & Variável $^{2}$ & Média & $E P^{3}$ & Equação ${ }^{4}$ & $\mathrm{P}<\mathrm{F}^{5}$ & $\mathrm{R}^{2}$ \\
\hline $\begin{array}{c}816 \\
2548 \\
3113\end{array}$ & MFP & $\begin{array}{l}3107 \\
4645 \\
7065\end{array}$ & $\begin{array}{l}402 \\
706 \\
583\end{array}$ & $\mathrm{MFP}=3.005+27,49^{*} \mathrm{e}^{0,0016^{*} \text { res }}$ & ** & 0,6298 \\
\hline $\begin{array}{c}816 \\
2548 \\
3113\end{array}$ & MFVP & $\begin{array}{l}2045 \\
3507 \\
5321\end{array}$ & $\begin{array}{l}284 \\
447 \\
642\end{array}$ & $\mathrm{MFVP}=1.939+29,27^{*} \mathrm{e}^{0,0015^{*} \text { es }}$ & * & 0,5904 \\
\hline $\begin{array}{c}816 \\
2548 \\
3113\end{array}$ & MFF & $\begin{array}{c}821 \\
2107 \\
1423\end{array}$ & $\begin{array}{l}111 \\
278 \\
179\end{array}$ & MFF $=-1.552+3,60^{\star}$ res $-0,00085^{\star}$ res $^{2}$ & ** & 0,9999 \\
\hline $\begin{array}{c}816 \\
2548 \\
3113\end{array}$ & MFH & $\begin{array}{l}1224 \\
1400 \\
3898\end{array}$ & $\begin{array}{l}214 \\
189 \\
510\end{array}$ & $\mathrm{MFH}=1.174+0,0119^{*} \exp ^{0,0039^{*} \text { res }}$ & 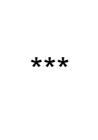 & 0,7646 \\
\hline $\begin{array}{c}816 \\
2548 \\
3113\end{array}$ & MFM & $\begin{array}{l}1062 \\
1138 \\
1743\end{array}$ & $\begin{array}{l}158 \\
298 \\
156\end{array}$ & ---- & NS & ---- \\
\hline $\begin{array}{c}816 \\
2548 \\
3113\end{array}$ & $\mathrm{~F} / \mathrm{H}$ & $\begin{array}{l}0,67 \\
1,50 \\
0,36\end{array}$ & $\begin{array}{l}0,19 \\
0,12 \\
0,04\end{array}$ & $\mathrm{~F} / \mathrm{H}=-1,8477+0,0041^{*}$ res $-1,0 * 10^{-6 *} \mathrm{res}^{2}$ & $* * *$ & 0,9991 \\
\hline
\end{tabular}

${ }^{1}$ Resíduo pós-pastejo, kg/ha de massa seca verde. ${ }^{2}$ MFP, massa de forragem da pastagem; MFVP, massa de forragem verde da pastagem; MFF, massa de forragem de folhas; MFH, massa de forragem de hastes; MFM, massa de forragem de material morto; F/H, relação folha/haste. ${ }^{3}$ Erro padrão da média. ${ }^{4}$ "res" representa o resíduo pós-pastejo. ${ }^{5}$ Significância, ${ }^{*} 5 \%$, ${ }^{* *} 1 \%$ e ${ }^{* * *} 0,1 \%$.

O comportamento exponencial da MFH e a resposta quadrática da MFF em relação ao resíduo pós-pastejo explicam a curva quadrática para a relação $\mathrm{F} / \mathrm{H}(\mathrm{P}<0,05$; Tabela 1$)$. Pela equação da relação $\mathrm{F} / \mathrm{H}$ apresentada na Tabela 1 , calcula-se que, no ponto de máximo dessa curva (1.880 kg/ha de MSV de resíduo pós-pastejo), o valor da relação F/H foi de 2,24, que é mais elevado do que aqueles indicados no trabalho de Canto et al. (2001), de 0,9 a 1,5 . 
$O$ efeito da massa de forragem residual sobre a MFVP foi significativo $(P<0,05$; Tabela 1). Em relação ao resíduo pós-pastejo inicial (816 kg/ha de MSV), a taxa de incremento na variável MFVP, conforme indicado pela equação de MFVP (Tabela 1), dobrou em 2.149 kg/ha de MSV de resíduo pós-pastejo. Pelas equações de MFF e MFH apresentadas na Tabela 1, entende-se que o aumento na MFVP, até resíduos pós-pastejo intermediários, foi resultante prioritariamente da produção de folhas. Para massas de forragem residuais intermediárias a lenientes, a MFH foi a principal determinante da MFVP.

A MFP também aumentou com o incremento na massa de forragem residual $(\mathrm{P}<0,05)$, observando-se que no resíduo de $2.066 \mathrm{~kg} / \mathrm{ha}$ de MSV a taxa de incremento na variável MFP dobrou (Tabela 1). Em adição à MFVP, o aumento na MFP também é explicado pela quantidade de material morto da pastagem. Embora essa variável não tenha sido afetada de maneira significativa pelo resíduo pós-pastejo $(P>0,05)$, nota-se que na massa de forragem residual de $3.113 \mathrm{~kg} / \mathrm{ha}$ de MSV a MFM foi 64\% e 53\% superior aos valores de MFM observados para os resíduos pós-pastejo de 816 e 2.548 kg/ha de MSV, respectivamente (Tabela 1 ).

Os maiores valores de MFF, MFH e MFVP observados nesse estudo, em relação aos experimentos com capim Tanzânia em sequeiro (Cecato et al., 2000; Canto et al., 2001), possivelmente são explicados pela utilização de irrigação, associada à fertilidade química do solo favorável e à elevada adubação, principalmente a nitrogenada $(80 \mathrm{~kg} / \mathrm{ha}$ de $\mathrm{N}$ por ciclo de pastejo). Entretanto, ressalta-se que a resposta absoluta da produção da planta forrageira àirrigação e àadubação é de maior magnitude durante o verão, conforme indicado nos trabalhos de Guelfi Filho (1972; 1976) e de Corsi \& Nussio (1993).

O efeito do método de pastejo também não pode ser descartado. O manejo com lotação contínua e o fato de a pastagem ter sido vedada por 70 dias antes das avaliações se iniciarem, no trabalho de Canto et al. (2001), pode ter reduzido, de maneira expressiva, a penetração de luz no interior da cobertura vegetal. Nessas condições, as perdas por senescência são potencializadas e a renovação da população de perfilhos e o acúmulo de folhas e de hastes são prejudicados, em razão da falta de luz em quantidade e qualidade adequadas (Ludlow, 1978; Parsons \& Chapman, 2000).

Ademais, Barbosa et al. (1996), em estudo com o capim Tanzânia (sem irrigação) na época de inverno, encontraram efeito crescente e linear do tempo de rebrota sobre o aparecimento de perfilhos. Assim, é plausível admitir que em condições irrigadas a renovação de perfilhos e, conseqüentemente, de folhas, será potencializada. Essa argumentação baseia-se no fato de que a redução no déficit hídrico (irrigação) tem efeito 
favorável sobre a longevidade e atividade fisiológica dos componentes da planta (Turner \& Begg, 1978). Além disso, a adubação nitrogenada tem correlação positiva com o perfilhamento e com o incremento no peso de perfilhos, sendo observado expressivo desenvolvimento de hastes em níveis elevados de adubação nitrogenada (Stobbs, 1975). O desenvolvimento de hastes favorece a penetração de luz no interior da cobertura vegetal (Robson, 1981), o que ajuda a explicar os expressivos incrementos observados na MFF e na MFH.

Parece sensato propor que o manejo da pastagem deve centrar no aumento da quantidade de folhas, uma vez que as folhas têm efeito positivo sobre a produção da planta forrageira e do animal em pastejo (Stobbs, 1975; Parsons \& Chapman, 2000). Contudo, a estrutura da pastagem também é importante, porque ela determina a penetração de luz no interior da cobertura vegetal e a acessibilidade das folhas para o animal. Embora a presença de hastes tenha efeito favorável sobre a distribuição de luz em camadas inferiores do dossel (Robson, 1981), com elevada quantidade de hastes na pastagem a acessibilidade das folhas aos animais em pastejo é prejudicada (Stobbs, 1975). Desse modo, a relação $\mathrm{F} / \mathrm{H}$ da pastagem também é um importante norteador de manejo.

Com base nessa discussão, o manejo do capim Tanzânia deveria pautar, em adição ao aumento da produção de folhas, pela maximização da relação $F / H$. A partir da faixa de resíduo pós-pastejo de 1.880 (ponto de máximo da relação $F / H$ ) a $2.120 \mathrm{~kg} / \mathrm{ha}$ de MSV (ponto de máximo da MFF), a estrutura da pastagem foi substancialmente alterada e a MFVP passou a ser representada predominantemente por hastes em detrimento de folhas (Tabela 1). Portanto, sugere-se que o manejo de Panicum maximum cv. Tanzânia no inverno, considerando ciclo de pastejo de 36 dias e prevendo a utilização de irrigação e de adubação nitrogenada, seja feito visando manter uma massa de forragem residual da ordem de 1.900 a $2.100 \mathrm{~kg} / \mathrm{ha}$ de MSV.

Finalmente, é pertinente traçar um paralelo com o trabalho de Penati (2002). A principal diferença entre os dois experimentos, em adição à análise estatística diferenciada (análise por meio de regressões versus comparação de médias), diz respeito ao protocolo de amostragem. No presente estudo, a amostragem de forragem foi feita considerando uma área de $4 \mathrm{~m}^{2}$ e a proporção dos componentes da pastagem foi realizada na touceira central da parcela. No trabalho de Penati (2002), cada repetição representou uma amostra composta por cinco subamostras de $1 \mathrm{~m}^{2}$, dispostas em linha transecta, e a proporção dos componentes da pastagem foi feita em cada uma dessas subamostras. Essas diferenças metodológicas não alteraram, de maneira expressiva, a estimativa da MFP. Na média de 
dois ciclos de pastejo de inverno (02/junho a 12/agosto), os valores de MFP, determinados por Penati (2002), foram inferiores aos estimados neste experimento em apenas $7 \%$. Entretanto, no presente trabalho, houve superestimativa da MFVP (65\%) em relação aos resultados de Penati (2002).

Essas considerações não permitem indicar qual protocolo de amostragem seria mais apropriado para o capim Tanzânia. Ao contrário, as diferenças observadas nas estimativas dos componentes de produção da forragem em uma mesma pastagem e época do ano sinalizam a necessidade de mais estudos para a determinação de estratégias adequadas de amostragem de forragem em pastagens cespitosas, visando contemplar, de maneira satisfatória, a variabilidade espacial e temporal que ocorre nesses ecossistemas.

\subsection{Conclusões}

O resíduo pós-pastejo para o capim Tanzânia irrigado e adubado com nitrogênio, no período de inverno, considerando ciclo de pastejo de 36 dias, deve ser de 1.900 a 2.100 $\mathrm{kg} / \mathrm{ha}$ de massa seca verde. Esse manejo possibilita maximizar a produção de folhas e a relação folha/haste da pastagem. 


\section{EFEITO DA INTENSIDADE DE DESFOLHA SOBRE A PRODUÇÃO DE FORRAGEM DO CAPIM TANZÂNIA IRRIGADO DURANTE A PRIMAVERA E O VERÃO}

\section{Resumo}

Poucos esforços foram realizados para determinar a intensidade adequada de desfolha para pastagens tropicais, em especial em condições irrigadas. O presente trabalho, seguindo um delineamento de blocos completos casualizados com quatro repetições, avaliou o efeito do resíduo pós-pastejo (1.210, 3.036 e $5.471 \mathrm{~kg} / \mathrm{ha}$ de massa seca verde - MSV) e do período de rebrota (9, 18 e 27 dias depois da adubação nitrogenada) sobre a produção de forragem de Panicum maximum cv. Tanzânia irrigado durante as estações de primavera e de verão. A massa seca da pastagem, a massa seca verde da pastagem (folhas+hastes) e a massa seca de folhas aumentaram linearmente $(\mathrm{P}<0,05)$ com acréscimos na massa de forragem residual ou com os dias de rebrota. Nas duas épocas, observou-se interação significativa $(P<0,05)$ entre o período de rebrota e o resíduo pós-pastejo para a massa seca de hastes. No verão, a relação folha/haste diminuiu $(\mathrm{P}<0,05)$ com 0 aumento da massa de forragem residual, mas, na primavera, houve interação significativa $(P<0,05)$ entre o período de rebrota e o resíduo pós-pastejo. $A$ quantidade de material morto aumentou $(\mathrm{P}<0,05)$ com o período de rebrota. O resíduo póspastejo para o capim Tanzânia irrigado e adubado com nitrogênio ( $80 \mathrm{~kg} / \mathrm{ha}$ de $\mathrm{N}$ em cada ciclo de pastejo), na primavera e no verão, considerando ciclo de pastejo de 36 dias, deve ser de 1.650 a $2.700 \mathrm{~kg} / \mathrm{ha}$ de MSV para assegurar que a produção de folhas e a relação folha/haste sejam próximas do máximo. 


\section{EFFECT OF GRAZING INTENSITY ON HERBAGE PRODUCTION OF IRRIGATED TANZANIA GRASS PASTURE DURING THE SPRING AND SUMMER SEASONS}

\section{Summary}

Little effort has been done in order to determine the adequate grazing intensity for tropical pastures, especially under irrigated conditions. The present study, evaluated the effect of post-grazing residues (1210, 3036 and $5471 \mathrm{~kg} / \mathrm{ha}$ of green dry matter - GDM) and length of regrowth (9,18 and 27 days after nitrogen fertilization) on herbage production of irrigated Panicum maximum cv. Tanzania pasture during the spring and summer seasons, using a randomized complete block design with four replicates. Total herbage dry mass, green herbage dry mass (leaves+stems) and leaf dry mass linearly increased $(P<0,05)$ with increasing residual stubble mass or days of regrowth. A significant interaction $(P<0,05)$ between length of regrowth and post-grazing residue was observed for stem dry mass in both seasons. During the summer, the leaf/stem ration decreased $(P<0,05)$ with increasing post-grazing residue, but in the spring, the interaction between regrowth period and postgrazing residue was significant $(P<0,05)$. The quantity of dead material increased $(P<0,05)$ with the length of regrowth. The residual stubble mass for irrigated, $\mathrm{N}$-fertilized ( $80 \mathrm{~kg} \mathrm{~N} / \mathrm{ha}$ in each grazing cycle) Tanzania grass pasture during the spring and summer seasons, considering a 36-day grazing cycle, should be around 1650 to $2700 \mathrm{~kg} / \mathrm{ha}$ of GDM to ensures that leaf production and leaf/stem ratio be close to the maximum.

\subsection{Introdução}

Nos últimos anos, o capim Tanzânia (Panicum maximum cv. Tanzânia) tornou-se uma das principais opções para sistemas intensivos de produção animal a pasto. Entretanto, essa forrageira, a exemplo de outras cultivares de $P$. maximum, é exigente em manejo. E, em termos de manejo da pastagem, destaca-se a importância da intensidade de desfolha, que condiciona a velocidade de rebrota da planta imediatamente depois do pastejo (Jones \& Carabaly, 1981; Parsons \& Chapman, 2000). Todavia, existem poucas informações na literatura, em especial de estudos de pastejo, sobre qual a intensidade de desfolha que deve ser imposta ao capim Tanzânia.

Em estudo realizado no período de setembro/95 a setembro/96, Cecato et al. (2000) verificaram que a altura residual de corte (20 ou $40 \mathrm{~cm}$ ) não teve efeito sobre a 
produção do capim Tanzânia. Os autores concluíram que o capim Tanzânia poderia ser manejado mais baixo, sem que houvesse prejuízo na produção de forragem. Em trabalho desenvolvido no período de dezembro a abril, verificou-se que a utilização do capim Tanzânia, em pastejo com lotação contínua, poderia ser feita em alturas de 20 a $80 \mathrm{~cm}$, sendo aconselhável evitar intensidades de desfolha próximas a esses limites (Cecato et al., 2001). Em experimento subseqüente (04/01/00 a 29/04/01), Cecato et al. (2002) concluíram que o manejo do capim Tanzânia deveria situar-se entre 40 a $60 \mathrm{~cm}$ de altura.

Entretanto, as metas de manejo determinadas para o pastejo com lotação contínua não são aplicáveis ao pastejo rotacionado. Ademais, a utilização da altura como índice de manejo deve ser encarada com cautela, uma vez que a estrutura da vegetação de $P$. maximum, para uma dada altura de pastejo, é alterada ao longo dos ciclos de crescimento (Costa et al., 1992; Penati, 2002; Quadros et al., 2002). No estudo de Quadros et al. (2002), por exemplo, verificou-se que alturas residuais no capim Tanzânia, variando de 53 a $74 \mathrm{~cm}$, corresponderam a resíduos pós-pastejo de 2.955 a $5.574 \mathrm{~kg} / \mathrm{ha}$ de massa seca verde (MSV), respectivamente.

Como critério alternativo de manejo, poderia-se utilizar a massa de forragem residual. Barbosa et al. (2002), trabalhando com dois níveis de massa de forragem residual (2.300 e 3.600 kg/ha de massa seca) no capim Tanzânia, no período de 4/11 a 16/12, observaram que, em razão de adaptações fisiológicas das plantas, o potencial de produção de forragem não foi alterado pelos resíduos estudados. Em experimento com duração de 14 meses, envolvendo três massas de forragem residuais - 1.266, 2.915 e $4.256 \mathrm{~kg} / \mathrm{ha}$ de MSV - em capim Tanzânia irrigado, Penati (2002) concluiu que a melhor estratégia para conciliar elevada produtividade de forragem com alta produtividade animal seria a utilização do resíduo intermediário. Esse resultado contrasta com aquele apresentado por Euclides et al. (1993). Esses autores indicaram não haver benefícios substanciais no incremento do ganho de peso dos animais a partir de uma massa de forragem de $900 \mathrm{~kg} / \mathrm{ha}$ de MSV. Essas diferenças, possivelmente podem ser atribuídas ao método de pastejo utilizado nos dois estudos, rotacionado no experimento de Penati (2002), e sob lotação contínua no trabalho de Euclides et al. (1993). Entretanto, ressalta-se que o máximo resíduo póspastejo avaliado no estudo de Euclides et al. (1993) foi de $1.100 \mathrm{~kg} / \mathrm{ha}$ de MSV. Em razão desse limite ser muito próximo ao resíduo ótimo preconizado pelos autores, de $900 \mathrm{~kg} / \mathrm{ha}$ de MSV, pode-se inferir que a falta de contraste satisfatório, na amplitude de resíduos póspastejo testados, não elimina a hipótese de que melhores ganhos de peso poderiam ser obtidos em maiores massas de forragem residuais. 
Informações quantitativas sobre os componentes da produção de forragem (folha, haste e material morto), em uma amplitude de massas de forragem residuais, são imprescindíveis para auxiliar a tomada de decisão sobre a intensidade de desfolha a ser praticada no capim Tanzânia. Todavia, informações desta natureza ainda não foram devidamente abordadas para as situações em que o capim Tanzânia foi manejado rotacionalmente, com base na massa seca residual. No trabalho de Barbosa et al. (2002), porque apenas duas condições de resíduo pós-pastejo foram consideradas. No experimento de Penati (2002), em razão da análise dos resultados ter considerado as massas de forragem residuais de modo qualitativo.

O presente trabalho, realizado concomitantemente ao estudo de Penati (2002), apresenta a resposta quantitativa dos componentes da produção de forragem de pastagem irrigada de $P$. maximum cv. Tanzânia, em face de variações na intensidade de desfolha, período de rebrota durante o ciclo de pastejo e época do ano.

\subsection{Material e Métodos}

Dois experimentos, correspondentes às épocas de primavera (24 de outubro a 25 de dezembro de 2000) e de verão (29 de novembro de 2000 a 30 de janeiro de 2001), foram realizados em pastagem irrigada de $P$. maximum cv. Tanzânia, em área experimental da Escola Superior de Agricultura "Luiz de Queiroz", Universidade de São

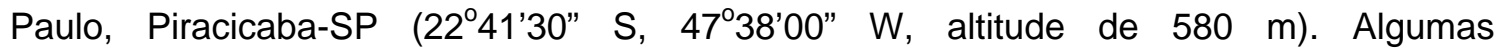
características do clima, durante os períodos experimentais, são apresentadas na Figura 1.

A irrigação foi feita por pivô central visando atingir a capacidade de campo quando tensiômetros instalados na profundidade de $20 \mathrm{~cm}$ indicaram potencial de água no solo de $-30 \mathrm{a}-40 \mathrm{kPa}$ (Lourenço \& Coelho, 2000).

O solo da área experimental, classificado como Podzólico Vermelho-escuro (Argissolo vermelho) de textura argilosa, apresentava 33\% de areia, $23 \%$ de silte e $44 \%$ de argila na camada de 0 a $20 \mathrm{~cm}$ de solo. As principais características químicas desse solo, para a camada de 0 a $20 \mathrm{~cm}$, foram: matéria orgânica $=25 \mathrm{~g} / \mathrm{kg} ; \mathrm{pH}$ em $\mathrm{CaCl}_{2}=5,1 ; \mathrm{P}$

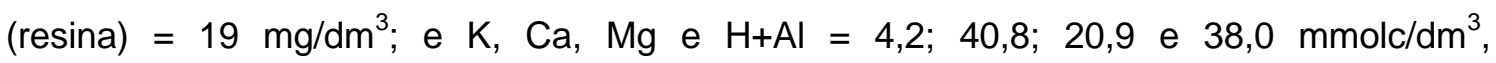
respectivamente. A correção e a adubação do solo seguiram as recomendações de Corsi \& Nussio (1993), visando elevar a saturação por bases para 70\% e o teor de fósforo (resina) e a proporção de potássio no solo para $20 \mathrm{mg} / \mathrm{dm}^{3}$ e 4 a $5 \%$ da CTC, respectivamente. Detalhes adicionais da área experimental foram apresentados por Penati (2002). 


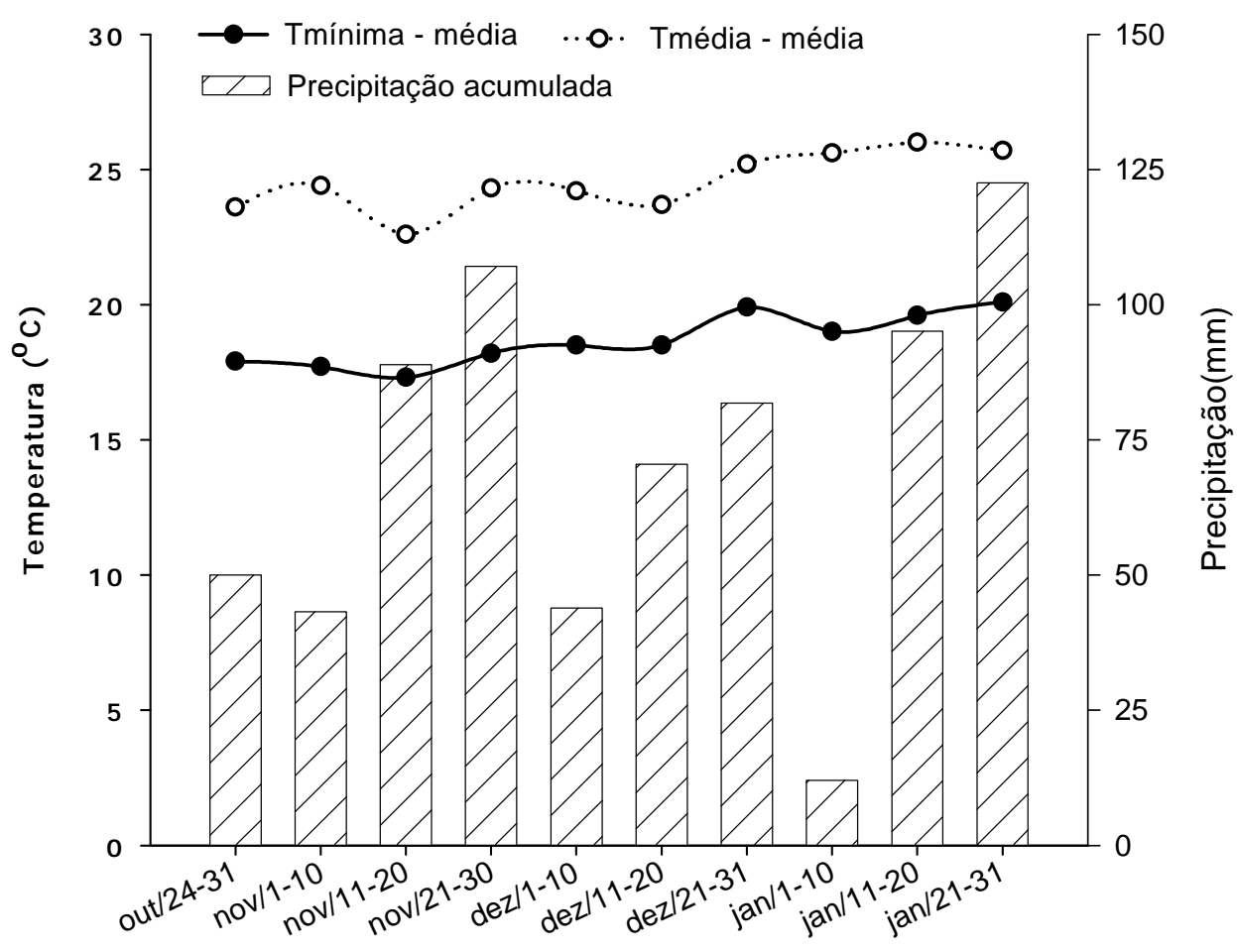

Figura 1 - Temperaturas médias (mínima e média) e precipitação pluvial acumulada em diferentes intervalos de tempo durante os períodos experimentais de primavera e de verão.

Nos experimentos de primavera e de verão, o delineamento experimental foi em blocos completos casualizados, com quatro repetições, no esquema de medidas repetidas no tempo. Para cada uma dessas épocas, tinha-se três massas de forragem residuais nas parcelas e três períodos de rebrota nas subparcelas. A meta inicial foi atingir massas de forragem residuais de 1.000, 2.500 e $4.000 \mathrm{~kg} / \mathrm{ha}$ de MSV. Entretanto, os valores médios observados, nas duas épocas, foram de $1.210,3.306$ e $5.471 \mathrm{~kg} / \mathrm{ha}$ de MSV no resíduo pós-pastejo, respectivamente (Penati, 2002). As alturas pós-pastejo correspondentes a essas massas de forragem residuais foram de 24,45 e $61 \mathrm{~cm}$, respectivamente (Penati, 2002). O período de rebrota foi representado por avaliações realizadas aos 9, 18 e 27 dias depois da adubação nitrogenada ( $80 \mathrm{~kg} / \mathrm{ha}$ de $\mathrm{N}$ por ciclo de pastejo), que ocorreu dois dias depois da saída dos animais dos piquetes. O ciclo de pastejo, de 36 dias, consistiu de 
três dias de ocupação e 33 dias de descanso. O pastejo foi feito por machos nelores castrados de 19 a 24 meses de idade.

Uma unidade amostral de $2 \mathrm{~m} \times 2 \mathrm{~m}$, tendo uma touceira do capim no seu centro geométrico, foi locada aleatoriamente em cada bloco $\left(1.333 \mathrm{~m}^{2}\right)$. O corte de amostragem da forragem foi feito ao nível do solo. As amostragens foram feitas de acordo com os tempos de rebrota indicados anteriormente. A forragem, colhida ao nível do solo nos $4 \mathrm{~m}^{2}$ da unidade amostral, foi pesada e teve sua massa seca determinada em estufa com ventilação forçada de $\operatorname{ar}\left(60^{\circ} \mathrm{C}\right.$ por $\left.72 \mathrm{~h}\right)$. $\mathrm{O}$ valor resultante correspondeu à massa de forragem da pastagem (MFP, $\mathrm{kg} / \mathrm{ha}$ de massa seca). Uma subamostra do material proveniente da touceira central de cada unidade amostral foi separada em folhas verdes (lâminas foliares), hastes verdes (caule+bainha) e material morto (folhas e hastes senescidas), sendo determinada a massa seca desses componentes em estufa com ventilação forçada de $\operatorname{ar}\left(60^{\circ} \mathrm{C}\right.$ por $\left.72 \mathrm{~h}\right)$. O material verde foi aquele com menos de $50 \%$ de tecido senescente. A resultante proporção de folha, haste e material morto, multiplicada pela MFP, possibilitou calcular a massa de forragem de folhas (MFF), de hastes (MFH) e de material morto (MFM), expressas em $\mathrm{kg} / \mathrm{ha}$ de massa seca. A soma de MFF e de MFH representou a massa de forragem verde da pastagem (MFVP). A razão entre os valores de MFF e de MFH correspondeu àrelação folha/haste $(F / H)$ da pastagem.

A análise dos resultados considerou os resíduos pós-pastejo observados. Os dados foram testados quanto à homogeneidade de variância e normalidade dos erros e a análise de variância, as equações de regressão e as correlações foram feitas utilizando-se os recursos do pacote estatístico SAS System (SAS, 1989). Em caso de interação significativa $(P<0,05)$ entre a massa de forragem residual e o período depois da adubação, os efeitos principais foram desconsiderados, sendo a análise estatística centrada na interação desses fatores. Quando os efeitos do resíduo pós-pastejo e do período depois da adubação foram significativos, porém, não se detectou efeito significativo da interação entre esses dois fatores, optou-se por análises de regressão múltiplas envolvendo o resíduo e o período, ao invés de análises de regressão simples com apenas um desses fatores.

\subsection{Resultados e Discussão}

O resíduo pós-pastejo e o período pós-adubação afetaram $(\mathrm{P}<0,05)$ a MFP. As taxas de acúmulo da MFP, de $243 \mathrm{~kg} / \mathrm{ha} /$ dia na primavera, e de $252 \mathrm{~kg} / \mathrm{ha} /$ dia no verão 
(Figuras 2a,b), foram superiores aos valores indicados em outros trabalhos com capim Tanzânia (Santos et al., 1999; Tosi, 1999; Barbosa et al., 2002).

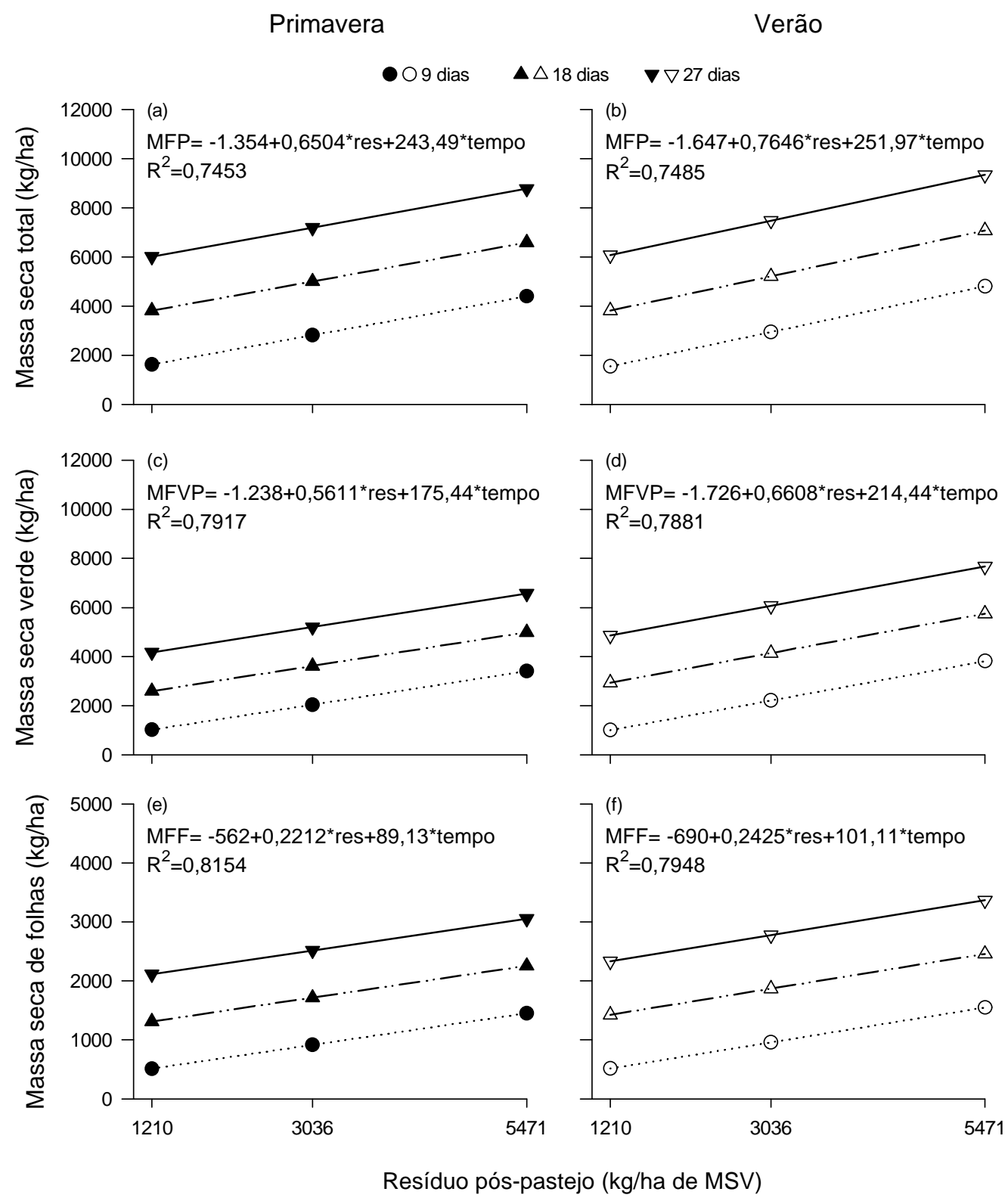

Figura 2 - Efeito do resíduo pós-pastejo ("res"; kg/ha de massa seca verde) e do período pós-adubação ("tempo"; dias) sobre a massa de forragem da pastagem (MFP), massa de forragem verde da pastagem (MFVP) e massa de folhas (MFF) em pastagem de capim Tanzânia na primavera (a, c, e) e no verão (b, d, f). As equações apresentadas são significativas $(P<0,0001)$. 
A utilização de irrigação e de elevados níveis de adubação, principalmente a nitrogenada (80 kg/ha de $\mathrm{N}$ em cada ciclo de pastejo), ajudam a explicar essa resposta mais favorável. Entretanto, é importante salientar que o período avaliado, de 11 a 29 dias de rebrota depois da saída dos animais dos piquetes, corresponde à fase linear de incremento na massa seca da pastagem, conforme se conclui das revisões de Rodrigues \& Rodrigues (1987) e de Parsons \& Chapman (2000). Quando se considerou todo o período de rebrota, essas taxas de acúmulo diminuíram, refletindo a contabilização da "fase lag" que ocorre nos primeiros dias de rebrota, em que o crescimento da planta forrageira é mais lento (Rodrigues \& Rodrigues, 1987; Parsons \& Chapman, 2000).

Assim, tomando como base o resíduo pós-pastejo e considerando a MFP aos 27

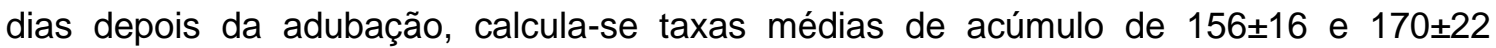
$\mathrm{kg} / \mathrm{ha} /$ dia de massa seca na primavera e no verão, respectivamente. Esses valores são de magnitude semelhante àqueles apontados por Santos et al. (1999) e Tosi (1999), mas são superiores aos indicados por Barbosa et al. (2002).

A massa de forragem residual não teve efeito sobre as taxas de acúmulo de forragem $(P>0,05)$ quando todo o período de rebrota foi considerado, o que está de acordo com os resultados obtidos por Barbosa et al. (2002). Na primavera, as taxas de acúmulo da MFP foram de 158 $\pm 28,152 \pm 27$ e $157 \pm 40 \mathrm{~kg} / \mathrm{ha} /$ dia de massa seca nos resíduos póspastejo de $1.210,3.036$ e $5.471 \mathrm{~kg} / \mathrm{ha}$ de MSV, respectivamente. Os respectivos valores, no verão, foram de $137 \pm 10,187 \pm 36$ e $195 \pm 69 \mathrm{~kg} / \mathrm{ha} /$ dia de massa seca.

Nas equações apresentadas nas Figuras 2a e $2 b$ observa-se que o efeito do resíduo pós-pastejo sobre a MFP foi de menor magnitude do que o efeito do período de rebrota. O incremento de $1 \mathrm{~kg} / \mathrm{h}$ a de MSV no resíduo pós-pastejo determinou acréscimos de 0,65 e 0,76 kg/ha na MFP durante a primavera e o verão, respectivamente. Desse modo, calcula-se que aumentos de 375 e 332 kg/ha de MSV no resíduo pós-pastejo, na primavera e no verão, respectivamente, teriam impacto semelhante a um dia de rebrota sobre a MFP.

Além disso, verifica-se pelas equações de MFP (Figuras 2a,b) e de MFVP (Figuras 2c,d), que o aumento na MFM correspondeu a 14\% da massa seca total da pastagem na primavera e no verão, uma vez que o aumento de uma unidade no resíduo pós-pastejo determinou incrementos $(P<0,05)$ de $0,56 \mathrm{~kg} / \mathrm{ha}$ na MFVP na primavera e de $0,66 \mathrm{~kg} / \mathrm{ha}$ na MFVP no verão. Quando o período pós-adubação foi considerado, o acréscimo na massa seca de material morto representou $28 \%$ da MFP na primavera e $14 \%$ da MFP no verão, 
posto que a MFVP, nessas épocas, aumentou $(\mathrm{P}<0,05)$ em 175 e $214 \mathrm{~kg} / \mathrm{ha} / \mathrm{dia}$, respectivamente.

Todavia, não se observou efeito do resíduo pós-pastejo sobre a variável MFM $(P>0,05)$. Esse comportamento contrasta com aquele observado por Cecato et al. (2001), que encontraram efeito significativo da altura de manejo do capim Tanzânia sob lotação contínua sobre a massa seca de material morto. Contudo, Zimmer (1999) e Penati (2002) observaram efeitos inconsistentes da massa de forragem residual sobre a quantidade de material morto em diferentes épocas de avaliação no ano.

O período depois da adubação, por outro lado, influenciou a MFM $(P<0,05)$, havendo, no entanto, pequenas diferenças na quantidade absoluta de material morto nas avaliações realizadas durante a primavera e o verão (Figura 3). Costa et al. (1992) e Santos (1997) também indicaram acréscimos na massa seca de material morto/tecido senescente na pastagem com o aumento do intervalo de rebrota. Esse fato, provavelmente, reflete as condições menos favoráveis de quantidade e de qualidade de luz no interior da cobertura vegetal com o avançar da rebrota da pastagem, que favorecem o processo de senescência (Parsons \& Chapman, 2000).

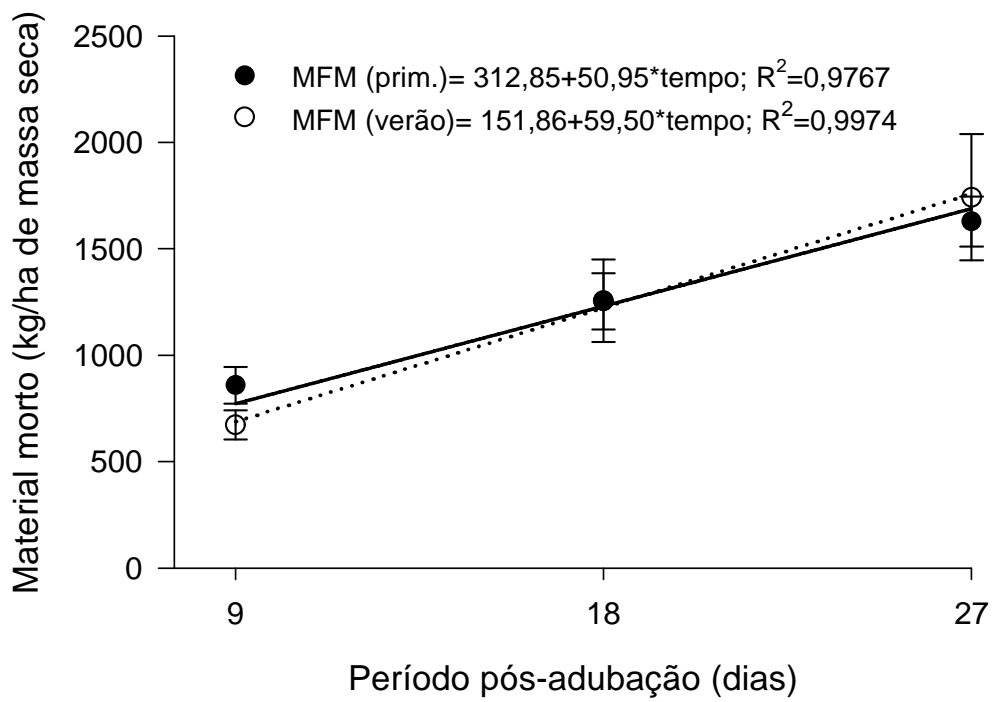

Figura 3 - Efeito do período pós-adubação (dias, "tempo"), na primavera e no verão, sobre a massa seca de material morto em pastagem de capim Tanzânia. As equações apresentadas são significativas $(P<0,0001)$. 
O incremento de $1 \mathrm{~kg} / \mathrm{ha}$ de MSV no resíduo pós-pastejo determinou acréscimos $(\mathrm{P}<0,05)$ médios de $0,22 \mathrm{~kg} / \mathrm{ha}$ na MFF na primavera e de $0,24 \mathrm{~kg} / \mathrm{ha}$ na MFF no verão (Figuras 2e e 2f). Em relação ao efeito do período pós-adubação, verificou-se aumentos $(\mathrm{P}<0,05)$ médios na massa seca de folhas de $89 \mathrm{~kg} / \mathrm{ha} /$ dia na primavera e de $101 \mathrm{~kg} / \mathrm{ha} / \mathrm{dia}$ no verão para o incremento de um dia no período de rebrota (Figuras 2e e 2f). Quanto à $\mathrm{MFH}$, constatou-se efeito da interação $(\mathrm{P}<0,05)$ entre o período pós-adubação e o resíduo pós-pastejo. Considerando o período de rebrota, na primavera (Figura 4a) e no verão (Figura 4c), verificou-se que a MFH apresentou valores semelhantes nos resíduos intermediário e leniente, particularmente depois de 18 dias da adubação nitrogenada. Em relação ao resíduo pós-pastejo, a MFH mostrou padrão semelhante de resposta em face do aumento na massa de forragem residual nas avaliações efetuadas aos 18 e 27 dias depois da adubação (Figura 4b,d).

De maneira geral, o efeito positivo do aumento na massa de forragem residual sobre a massa seca de folhas e de hastes pode ser atribuído à manutenção de condições mais favoráveis de (Gomide et al., 1979; Thronton \& Millard, 1996; Pagotto, 2001; Mello, 2002): 1) índice de área foliar residual, que permite maior interceptação de luz e, conseqüentemente, maiores taxas de fotossíntese logo depois do evento de pastejo; 2) reservas fisiológicas na planta, que apresenta efeito favorável sobre o crescimento da forrageira no início do período de rebrota, quando verifica-se baixo índice de área foliar residual e atividade fotossintética reduzida; e 3) crescimento de raízes, que favorece a aquisição de água e nutrientes para sustentar o crescimento da planta imediatamente depois da desfolha.

Ainda, a desfolha leniente pode ter contribuído para a menor eliminação de meristemas apicais, favorecendo a velocidade e o vigor de rebrota (Gomide et al., 1979). A ação conjunta de IAF residual mais elevado, "status" mais favorável de reservas fisiológicas na planta, maior crescimento de raízes e menor eliminação de pontos de crescimento provavelmente contribuiu para o restabelecimento de condições fisiológicas favoráveis à rápida recuperação da planta forrageira logo depois do pastejo.

Cabe comentar que o aumento no tempo de rebrota potencializou a ação favorável da maior massa de forragem residual na produção da pastagem (Figuras 2 e 4), possivelmente, em razão de acréscimos no IAF (Mello, 2002) e no crescimento de raízes (Pagotto, 2001), que possibilitam o rápido restabelecimento de balanço positivo de carbono na planta subseqüentemente ao pastejo (Thornton \& Millard, 1996; Corsi et al., 2001b). Com efeito, verifica-se que incrementos na massa de forragem residual, de 318 e 413 
$\mathrm{kg} / \mathrm{ha}$ de MSV, na média de primavera e de verão, tiveram efeito similar ao obtido com apenas um dia de rebrota sobre a MFVP e a MFF, respectivamente (Figuras 2c,d,e,f).

(a)

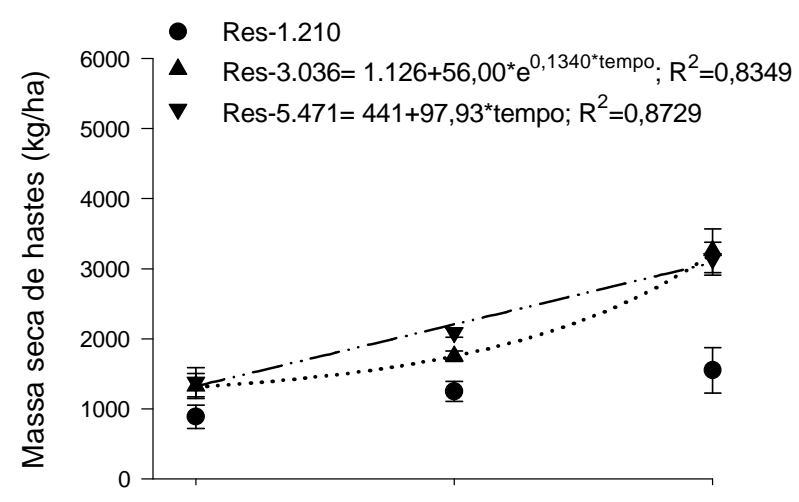

(c)

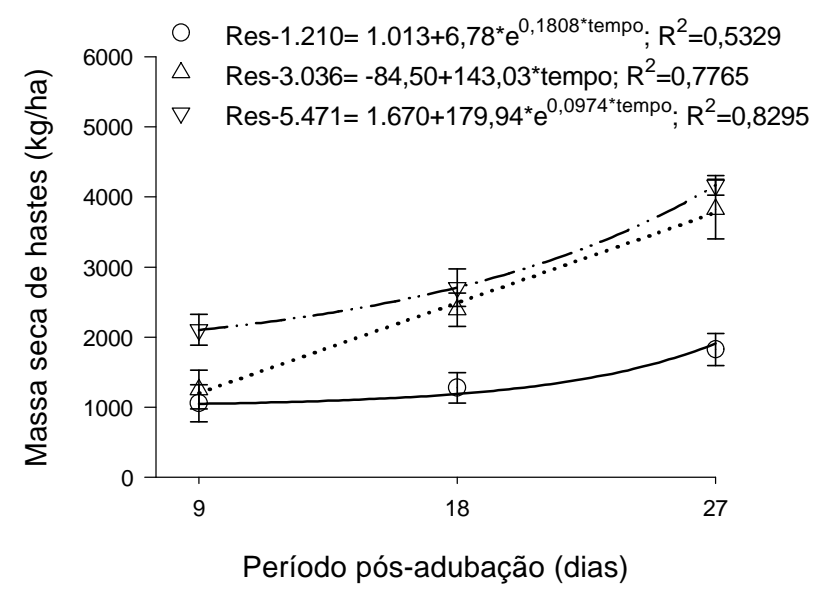

(b)

- Tempo-9=728+0,1691*res; $\mathrm{R}^{2}=0,9615$

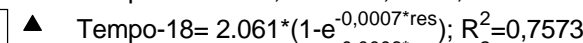

$\boldsymbol{\nabla}$ Tempo- $27=3.520^{*}\left(1-\mathrm{e}^{-0,0006^{*} \mathrm{res}}\right) ; \mathrm{R}^{2}=0,6332$

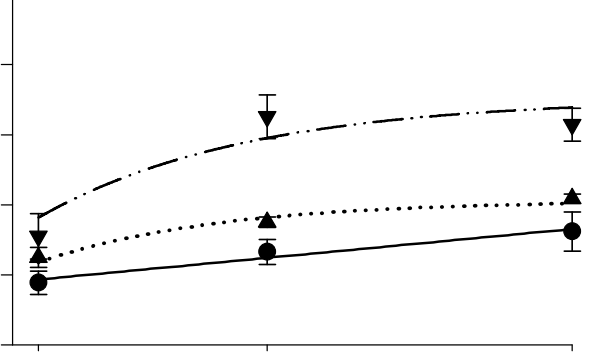

(d)

○ Tempo- $9=791^{*} \mathrm{e}^{0,0002^{*} \text { res }} ; \mathrm{R}^{2}=0,5135$

$\triangle$ Tempo-18 $=3.006^{*}\left(1-\mathrm{e}^{-0,0005^{*} \mathrm{res}}\right) ; \mathrm{R}^{2}=0,7106$

$\nabla \quad$ Tempo-27 $=4.547^{*}\left(1-\mathrm{e}^{-0,0005^{*} \mathrm{res}}\right) ; \mathrm{R}^{2}=0,9070$

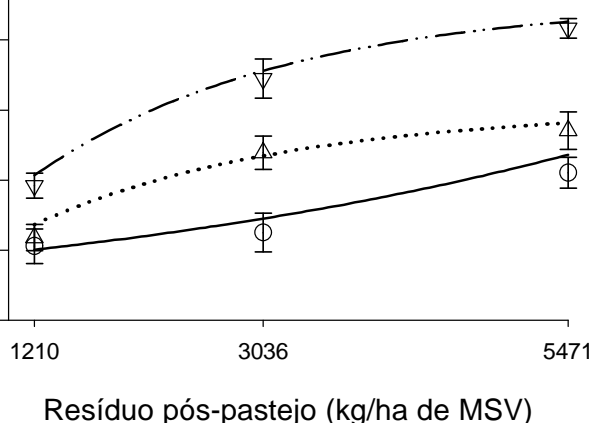

Figura 4 - Efeito do resíduo pós-pastejo ("res”; kg/ha de massa seca verde) e do período pós-adubação ("tempo"; dias) sobre a massa seca de hastes em pastagem de capim Tanzânia na primavera (a, b) e no verão (c, d). As equações apresentadas são significativas $(\mathrm{P}<0,05)$.

Entretanto, nem sempre se observa efeito positivo da menor intensidade de pastejo sobre a produção de forragem. Cecato et al. (2000) observaram relação inversa entre a altura residual de desfolha e a massa seca de folhas. Nos cortes de 20 e $40 \mathrm{~cm}$ de altura a quantidade de folhas acumuladas em quatro ciclos de crescimento de verão foi de 13,6 e 
$11,0 \mathrm{t} / \mathrm{ha}$, respectivamente. Nesse mesmo período, a MFVP foi de $16,6 \mathrm{t} / \mathrm{ha}$ na altura residual de $20 \mathrm{~cm}$ e de 12,3 t/ha nos cortes feitos a $40 \mathrm{~cm}$.

Ressalta-se que o acréscimo na MFF, em resposta ao aumento do resíduo póspastejo, representou, na média das duas épocas, 38\% do incremento observado na MFVP (Figuras 2c,d,e,f). Quando o período de rebrota foi considerado, a MFF correspondeu, na média de primavera e de verão, a 49\% do aumento na MFVP (Figuras 2c,d,e,f). Verifica-se, dessa maneira, que aumentos no resíduo pós-pastejo possibilitaram maior acúmulo de hastes do que de folhas, particularmente durante o verão (Figuras 2 e 4). Esse comportamento possivelmente refletiu a presença de perfilhos de idade fisiológica mais avançada e, portanto, mais pesados, em pastagens manejadas sob regime de desfolha leniente (Santos, 2002). O aumento na MFH, no verão, também pode estar associado ao início da indução ao florescimento, pois perfilhos reprodutivos são mais pesados do que perfilhos vegetativos (Korte et al., 1984).

A relação $\mathrm{F} / \mathrm{H}$, no verão, diminuiu $(\mathrm{P}<0,05)$ com o aumento da massa de forragem residual (Figura 5). No entanto, na primavera, houve efeito $(P<0,05)$ da interação entre a massa de forragem residual e o período pós-adubação sobre a relação F/H (Figura 6). Nessa época do ano, a relação $\mathrm{F} / \mathrm{H}$ aumentou linearmente com o tempo depois da adubação quando o pastejo foi intenso (Figura 6a), porém, reduziu de maneira exponencial com o incremento na massa de forragem residual quando o período de 27 dias depois da adubação foi considerado (Figura 6b). Aos 18 dias depois da adubação, a resposta da relação $\mathrm{F} / \mathrm{H}$ foi quadrática, apresentando ponto de máximo em um resíduo pós-pastejo de $2.826 \mathrm{~kg} / \mathrm{ha}$ de MSV (Figura 6b).

O fato de a maior proporção da MFVP ser representada por hastes parece justificar a proposta de que o manejo de $P$. maximum deve centrar no controle de hastes, visando favorecer a qualidade da forragem e facilitar o manejo da pastagem (Santos et al., 1999; Santos, 2002). Entretanto, a redução na participação de hastes na pastagem não pode ser o único critério de manejo, pois, se isso acontecer, pode-se penalizar, de maneira sensível, a produção de folhas. As correlações positivas e significativas $(P<0,0001)$ entre MFF e MFH observadas nesse estudo, tanto na primavera $(r=0,9131)$ como no verão $(r=$ 0,9024), dão suporte a essa idéia. De acordo com Robson (1981), a presença de hastes influencia positivamente a produção de forragem, em razão de favorecer a distribuição de luz em camadas inferiores do dossel. 


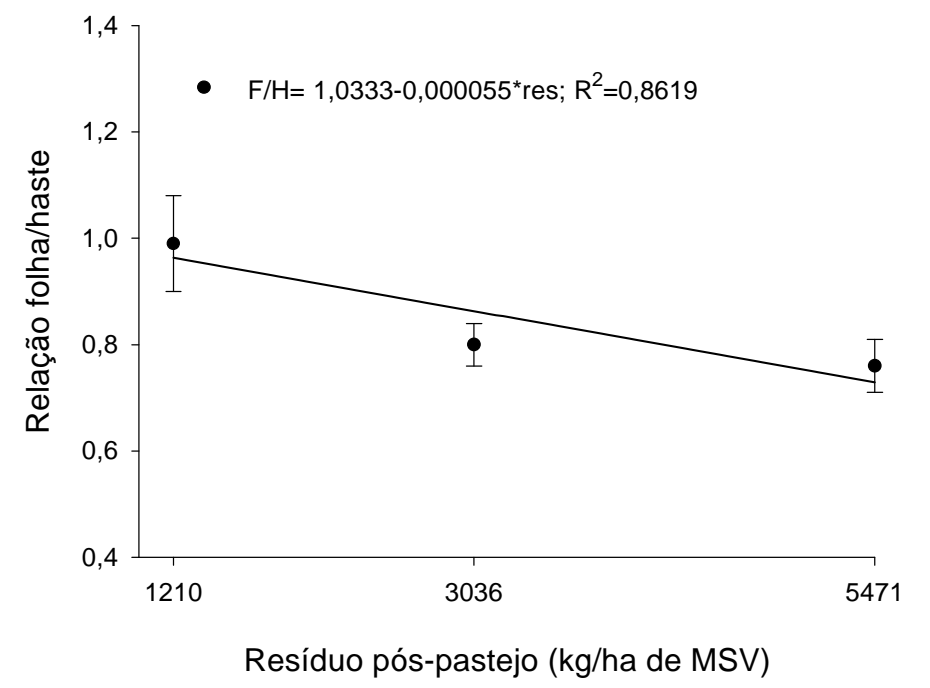

Figura 5 - Efeito do resíduo pós-pastejo ( $\mathrm{kg} / \mathrm{ha}$ de massa seca verde, "res"), no verão, sobre a relação folha/haste de pastagem de capim Tanzânia. A equação apresentada é significativa $(P<0,0127)$.

(a)

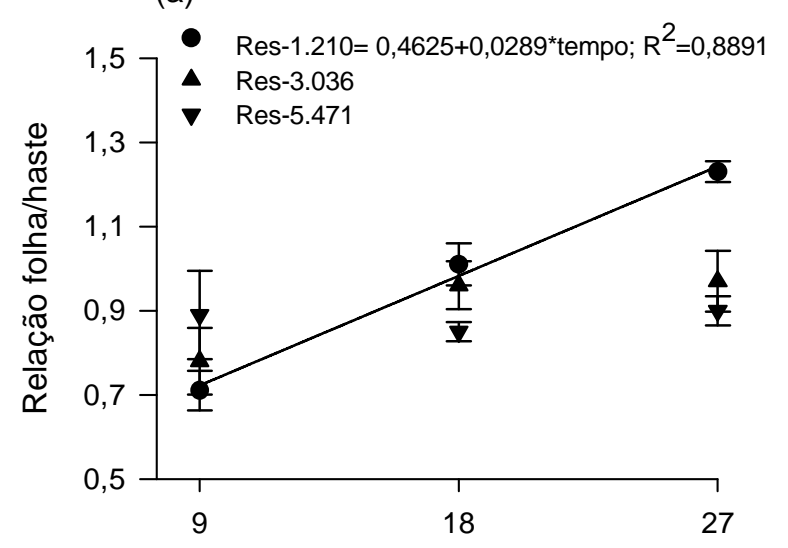

Período pós-adubação (dias) (b)

- $9 d$

- $18 \mathrm{~d}=0,8367+0,00013^{*}$ res $-2,3^{*} 10^{-8 *}{ }^{*} \mathrm{res}^{2} ; \mathrm{R}^{2}=0,8456$

$\boldsymbol{\nabla} 27 d=0,8966+3,3827^{\star} e^{-0,0019^{*} \text { res }} ; R^{2}=0,9115$

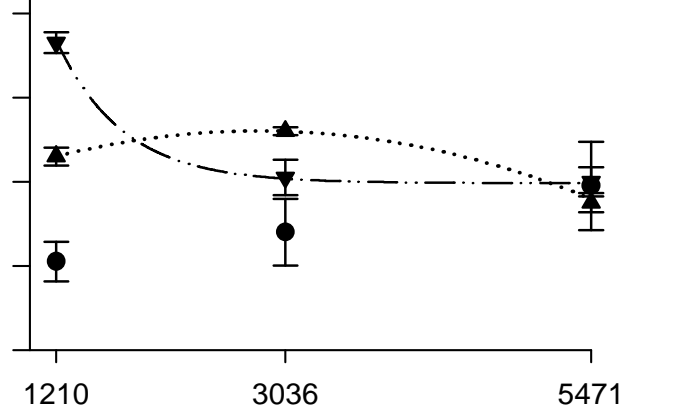

Resíduo pós-pastejo (kg/ha de MSV)

Figura 6 - Efeito do resíduo pós-pastejo ("res"; kg/ha de massa seca verde) e do período pós-adubação nitrogenada ("tempo"; dias), na primavera, sobre a relação folha/haste de pastagem de capim Tanzânia. As equações apresentadas são significativas $(P<0,001)$. 
Ademais, o comportamento errático da $\mathrm{MFH}$, principalmente em relação ao intervalo de rebrota, mas, também, em função do resíduo pós-pastejo (Figura 4), ratifica a argumentação de que o manejo centrado exclusivamente no controle de hastes pode proporcionar resultados inconsistentes e, por vezes, desfavoráveis sobre a produção de forragem. Assim, critérios adicionais de manejo devem ser utilizados, como a massa seca de folhas e a relação $\mathrm{F} / \mathrm{H}$ da pastagem.

Em trabalho com capim Tanzânia irrigado, envolvendo três resíduos pós-pastejo (816, 2.548 e $3.1134 \mathrm{~kg} / \mathrm{ha}$ de MSV), durante o inverno, verificou-se que a utilização dos indicadores de manejo - minimização da participação de hastes e maximização da produção de folhas e da relação $\mathrm{F} / \mathrm{H}$ - apresentou resultados satisfatórios (capítulo 3). Nesse estudo, a proposta de trabalhar com resíduos pós-pastejo entre 1.900 a $2.100 \mathrm{~kg} / \mathrm{ha}$ de MSV reduziria a MFVP pela metade em relação ao maior resíduo pós-pastejo testado (3.113 kg/ha de MSV), mas não alteraria a produção de folhas.

A aplicação dessa proposta de manejo, no presente estudo, não é, no entanto, facilmente equacionada. Considerando os 27 dias depois da adubação, observa-se que primar pela maximização da relação $\mathrm{F} / \mathrm{H}$ ou pela minimização da $\mathrm{MFH}$ indicaria que 0 manejo da pastagem, na primavera e no verão, deveria ter como meta a obtenção de resíduos pós-pastejo próximos a $1.210 \mathrm{~kg} / \mathrm{ha}$ de MSV (Figuras 4 e 6). Entretanto, a manutenção dessa massa de forragem residual mostrou sinais de que a produtividade da pastagem seria insustentável ao longo do tempo (Penati, 2002), possivelmente em razão da combinação de (Gomide et al., 1979; Jones \& Carabaly, 1981; Thronton \& Millard, 1996; Mello, 2002; Pagotto, 2001) baixo IAF residual, "status" desfavorável de reservas fisiológicas na planta, pequeno crescimento de raízes subseqüentemente à desfolha e elevada eliminação de meristemas apicais.

Em contrapartida, maximizar a produção de folhas estaria associada com massas de forragem residuais de aproximadamente $5.471 \mathrm{~kg} / \mathrm{ha}$ de MSV, o que implicaria, também, na maximização da produção de hastes, levando a uma inevitável redução da relação $F / H$ da pastagem (Figuras 2, 4, 5, 6b). Ademais, com resíduos pós-pastejo lenientes, observase maiores perdas de forragem e menor capacidade de suporte da pastagem, que determinam produtividade animal menos satisfatória do que em intensidades de desfolha moderadas (Penati, 2002).

Em termos práticos, como nenhuma dessas propostas - pastejos intensos ou lenientes - são válidas, poderia-se propor como meta um resíduo pós-pastejo intermediário, em que houvesse equilíbrio entre a massa seca de folhas e de hastes, o que 
possibilitaria conciliar boa produtividade com valor nutritivo satisfatório da forrageira, conforme sugerido por Gomide (1994). Esse autor apontou que essa condição seria obtida com relação F/H ao redor de 1, embora, do estudo de Penati (2002), depreenda-se que relações $\mathrm{F} / \mathrm{H}$ de 0,8 a 1,0 teriam impactos semelhantes no desempenho dos animais em pastejo, desde que a disponibilidade de forragem fosse mantida em patamares elevados.

Considerando como ponto inicial para o manejo o intervalo de massas de forragem residuais correspondentes a relações $\mathrm{F} / \mathrm{H}$ entre 0,8 e 1,0, teria-se, como meta, a obtenção de resíduos pós-pastejo de 1.650 a $3.100 \mathrm{~kg} / \mathrm{ha}$ de MSV e 1.500 a $2.700 \mathrm{~kg} / \mathrm{ha}$ de MSV na primavera (Figura 7a) e no verão (Figura 7b), respectivamente. Na primavera, houve pouca variação na relação $\mathrm{F} / \mathrm{H}$ a partir do resíduo de $3.100 \mathrm{~kg} / \mathrm{ha}$ de MSV.

Conforme discutido anteriormente, essa proposta de manejo não deveria afetar, de maneira expressiva, a produção de folhas. Pelas equações apresentadas nas Figuras $2 \mathrm{e} e$ $2 f$ estima-se que, na primavera, a redução do resíduo pós-pastejo para 30\% a 57\% (1.650 a $3.100 \mathrm{~kg} / \mathrm{ha}$ de MSV) do máximo valor testado (5.471 kg/ha de MSV) estaria associada com uma massa seca de folhas equivalente a $72 \%$ a $83 \%$ da máxima produção observada. No verão, a diminuição da massa de forragem residual para 27\% a 49\% (1.500 a 2.700 $\mathrm{kg} / \mathrm{ha}$ de MSV) do máximo valor testado (5.471 kg/ha de MSV) implicaria em uma produção de folhas equivalente a 71 a $80 \%$ da máxima massa seca de folhas verificada. Nessas condições, a massa seca de hastes representaria $65 \%$ a $88 \%$ e $56 \%$ a $79 \%$ das máximas produções obtidas na primavera e no verão, respectivamente (Figuras 4b e 4d).

Tomando o valor médio das amplitudes de resíduo pós-pastejo propostas na Figura 7, calcula-se que a redução de 4,1 (Figura 2f) a 4,5 (Figura 2e) unidades na massa de forragem residual determinaria a diminuição de uma unidade na massa seca de folhas. Dessa maneira, a sugestão de se trabalhar com resíduos pós-pastejo de 1.650 a 3.100 $\mathrm{kg} / \mathrm{ha}$ de MSV, na primavera, e de 1.500 a $2.700 \mathrm{~kg} / \mathrm{ha}$ de MSV, no verão, parece viável, embora o controle da massa seca de hastes não tenha sido efetivo, contrariando o comportamento observado no período de inverno (capítulo 3).

Contudo, uma vez que a massa de forragem residual tende a aumentar ao longo da estação de pastejo (Penati, 2002; Quadros et al., 2002), o máximo resíduo pós-pastejo na primavera deve ser menor ou igual ao limite superior proposto para o verão, de $2.700 \mathrm{~kg} / \mathrm{ha}$ de MSV (Figura 7). Por esse mesmo motivo, o limite inferior de massa de forragem residual proposto para o verão deve ser igual ou superior ao indicado para a primavera, de 1.650 $\mathrm{kg} / \mathrm{ha}$ de MSV. 

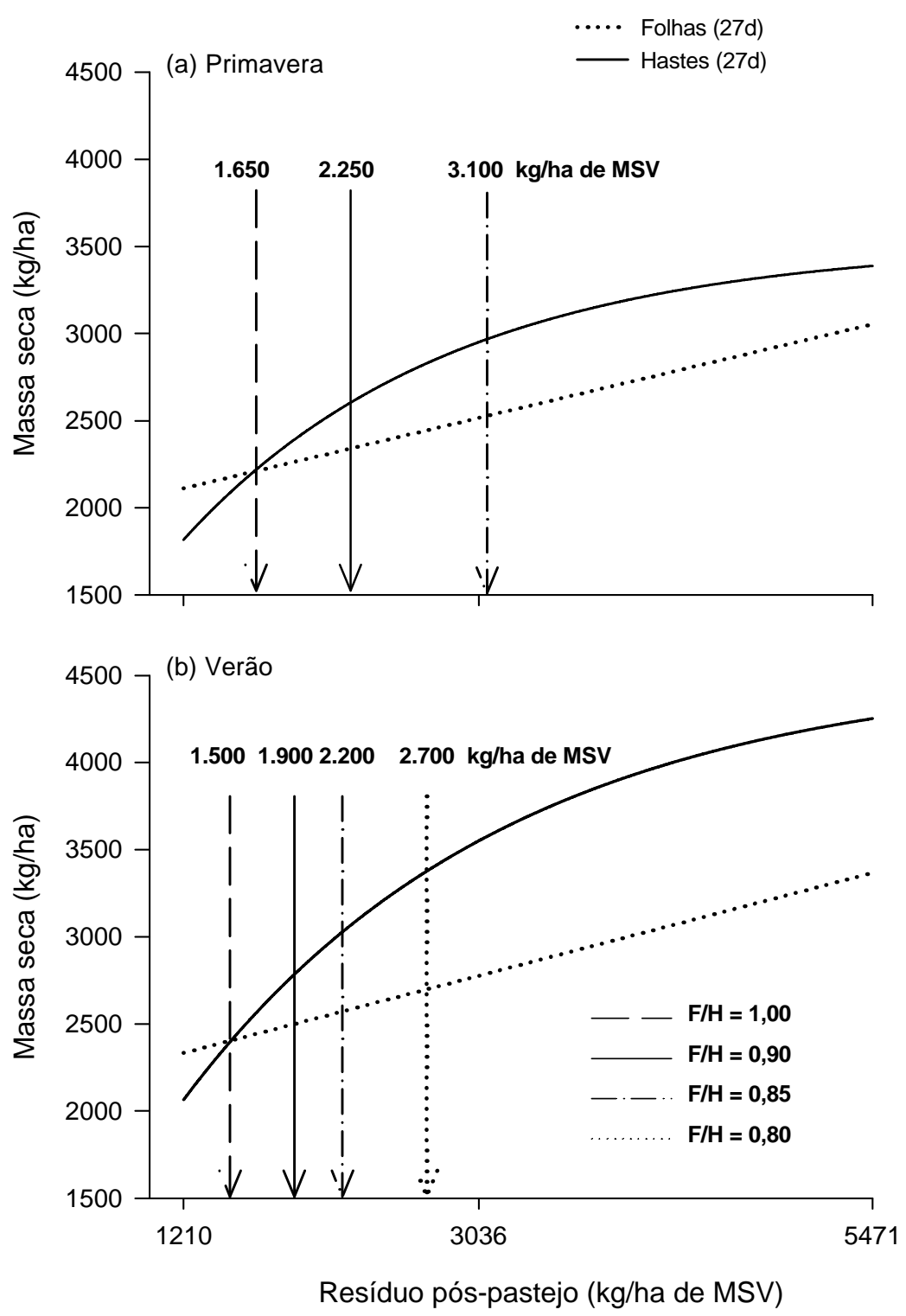

Figura 7 - Massa seca de hastes e de folhas e relação folha/haste, aos 27 dias depois da adubação, na primavera (a) e no verão (b), em função de variações no resíduo pós-pastejo (kg/ha de massa seca verde). As equações apresentadas constam das Figuras 2 e 3.

Portanto, o resíduo pós-pastejo, na primavera e no verão, deveria situar-se entre 1.650 e $2.700 \mathrm{~kg} / \mathrm{ha}$ de MSV. Com esses níveis de massa de forragem residual, teria-se, potencialmente, a manutenção da estrutura da pastagem e da qualidade da forragem em 
patamares favoráveis ao desempenho do animal (Balsalobre, 2002; Penati, 2002), não havendo alteração substancial da produção de folhas, em razão de não haver comprometimento expressivo dos processos fisiológicos da planta forrageira imediatamente depois do pastejo (Pagotto, 2001; Mello, 2002). Pode-se inferir, também, que nessa amplitude de massa de forragem residual, não haveria redução significativa na capacidade de suporte da pastagem, em razão do aumento da eficiência de colheita de forragem e da diminuição das perdas devidas ao pastejo, conforme constatado por Penati (2002).

À parte essas considerações, reconhece-se que mais estudos, em especial sobre a viabilidade econômica do empreendimento, são necessários para melhor avaliar a proposta de se trabalhar com resíduos pós-pastejo de 1.700 a $2.700 \mathrm{~kg} / \mathrm{ha}$ de MSV na primavera e no verão. Seria interessante que esses trabalhos considerassem pelo menos quatro níveis de massa de forragem residual, no sentido de proporcionar maior robustez à análise dos resultados.

\subsection{Conclusões}

O manejo do capim Tanzânia na primavera e no verão, considerando ciclo de pastejo de 36 dias e prevendo a utilização de irrigação e de adubação nitrogenada, deve ser feito visando manter uma massa de forragem residual da ordem de 1.650 a $2.700 \mathrm{~kg} / \mathrm{ha}$ de massa seca verde. 


\section{EXIGÊNCIAS DO TAMANHO DA PARCELA EM ESTUDOS DE RECUPERAÇÃO DE FERTILIZANTE- ${ }^{15} \mathrm{~N}$ POR CAPIM TANZÂNIA IRRIGADO SOB DIFERENTES INTENSIDADES DE DESFOLHA}

\section{Resumo}

O entendimento da dinâmica do nitrogênio $(\mathrm{N})$ em ecossistemas de pastagens pode ser aprimorado por estudos utilizando a técnica do traçador ${ }^{15} \mathrm{~N}$. Entretanto, deve-se assegurar, nesses experimentos, que o movimento lateral do traçador não interfira nos resultados. Nesse contexto, foram determinadas as exigências quanto ao tamanho da parcela para experimentos com pastagem irrigada de Panicum maximum cv. Tanzânia adubada com ${ }^{15} \mathrm{~N}$ e manejada sob intensidade de pastejo leniente, moderada e intensa no inverno, na primavera e no verão. Parcelas de $1 \mathrm{~m}^{2}$, com uma touceira do capim em seu centro geométrico, foram adequadas para avaliar a recuperação do $\mathrm{N}$ do fertilizante, independentemente da intensidade de desfolha e época do ano. O aumento na distância da área adubada com ${ }^{15} \mathrm{~N}$ afetou negativamente o $\mathrm{N}$ proveniente do fertilizante ( $\mathrm{Npfm}$ ) recuperado na forragem. As menores taxas de declínio nos valores de $\mathrm{Npfm}$ com o aumento da distância da área adubada com ${ }^{15} \mathrm{~N}$ foram observados para as intensidades de pastejo leniente e moderada e, esse fato, pode ser explicado pelas características de crescimento vigoroso dessas plantas. $O$ aumento na intensidade de pastejo resultou na redução da massa da touceira. Quanto menor a touceira, maior a sua dependência no nitrogênio do fertilizante. 


\section{PLOT SIZE REQUIREMENTS IN EXPERIMENTS OF ${ }^{15} \mathrm{~N}$-FERTILIZER RECOVERY BY IRRIGATED TANZANIA GRASS UNDER DIFFERENT GRAZING INTENSITIES}

\section{Summary}

The understanding of the nitrogen $(\mathrm{N})$ dynamics in pasture ecosystems can be improved by studies using the ${ }^{15} \mathrm{~N}$ tracer technique. However, it must be ensured in these experiments that the lateral movement of the tracer will not interfere with the results. In this context, the plot-size requirements for experiments with irrigated Panicum maximum $\mathrm{cv}$. Tanzania pasture fertilized with ${ }^{15} \mathrm{~N}$ and managed under light, moderate and heavy grazing intensities in the winter, spring and summer seasons were determined. A plot-size of $1 \mathrm{~m}^{2}$, with a tussock of the grass in its geometric center, was adequate to evaluate the $\mathrm{N}$-fertilizer recovery, irrespective of grazing intensity and season of the year. Increasing the distance from the area fertilized with ${ }^{15} \mathrm{~N}$ negatively affected the nitrogen derived from fertilizer (Ndff) recovered in herbage. Lowest declining rates in Ndff values with increasing distance from

the area fertilized with ${ }^{15} \mathrm{~N}$ were observed for moderate and light grazing intensities and this fact might be explained by the vigorous growth characteristics of these plants. Increasing the grazing intensity resulted in decreased tussock mass. The smaller the tussock mass the greater was the reliance on the fertilizer nitrogen.

\subsection{Introdução}

Experimentos em laboratório ou em casa-de-vegetação têm sido extensivamente realizados em estudos básicos sobre ciclagem e transformações do nitrogênio $(\mathrm{N})$ em ecossistemas de pastagens. No entanto, é questionável se as conclusões de experimentos sob condições controladas podem ser extrapoladas para plantas crescendo no campo em razão de: 1) diferenças na morfologia e fisiologia da parte aérea e de raízes de plantas crescendo no campo e em laboratório/casa-de-vegetação; e 2) flutuações nas características de ambiente experimentadas no campo. Portanto, quando o objetivo do experimento é ter aplicabilidade prática, como a avaliação da recuperação do $\mathrm{N}$ do fertilizante pelas plantas forrageiras, é necessário desenvolver experimentos sob condições mais realistas, o que requer ensaios em campo (Powlson \& Barraclough, 1993).

Experimentos de campo com fertilizante- ${ }^{15} \mathrm{~N}$ podem utilizar parcelas confinadas ou parcelas sem barreiras físicas (i.e. parcelas não confinadas ou "parcelas de campo"). 
Parcelas confinadas são interessantes de usar porque facilitam a mais completa contabilização do $\mathrm{N}$ em estudos de balanço de ${ }^{15} \mathrm{~N}$, mais do que seria possível com parcelas em campo. Ademais, parcelas confinadas evitam os problemas associados com o movimento lateral da fonte marcada, independentemente desse movimento ocorrer por fluxo de massa ou por difusão no solo ou por translocação nos tecidos da planta (Sanchez et al., 1987; Powlson \& Barraclough, 1993).

O movimento lateral do $\mathrm{N}$ do fertilizante é uma fonte potencial de erro em experimentos de campo objetivando determinar a recuperação do $\mathrm{N}$-fertilizante pelas culturas. Problemas associados com o movimento lateral do fertilizante são especialmente importantes em estudos com o traçador ${ }^{15} \mathrm{~N}$, porque o elevado custo do fertilizante marcado encoraja a utilização da menor parcela possível e porque as exigências quanto ao tamanho da parcela são, em grande parte, determinadas pelo movimento lateral do traçador (Sanchez et al., 1987).

Entretanto, a colocação de barreiras no solo para confinar as parcelas pode introduzir condições artificiais no sistema solo-planta que, em última análise, afetam a recuperação do $\mathrm{N}$ do fertilizante pelas plantas forrageiras em razão: 1) da incapacidade da parte aérea ou do sistema radicular em reassumir crescimento normal (forma e tamanho); 2) da ruptura dos sistemas de macroporos do solo; 3) do estabelecimento de "poros artificiais" no solo; e 4) do deslocamento do solo adjacente à parede do lisímetro. Esses três últimos fatores podem aumentar a aeração e o movimento de água e de solutos no solo o que, por sua vez, pode influenciar a absorção de N (Sanchez et al., 1987; Powlson \& Barraclough, 1993; Trivelin et al., 1994b).

Em um pré-experimento com Panicum maximum cv. Tanzânia, as condições artificiais geradas pelo uso de parcelas confinadas (tubos de $25 \mathrm{~cm}$ de diâmetro inseridos no solo a uma profundidade de $40 \mathrm{~cm}$ ) foram tão drásticas que o crescimento da gramínea foi severamente restringido. Uma semana depois da desfolha, a altura média das plantas fora e dentro das microparcelas foi de 60 a 70 e 30 a $40 \mathrm{~cm}$, respectivamente; em alguns casos, a touceira compreendida pela microparcela confinada chegou a morrer (Martha Júnior, 2000).

Para situações como essa, os resultados sobre a recuperação do fertilizante- ${ }^{15} \mathrm{~N}$ pela planta forrageira são incorretos e não devem ser considerados. Parcelas confinadas de maior tamanho podem ser uma opção para essas situações, no entanto, o trabalho de campo é mais complicado e trabalhoso. Ademais, não há garantia de que parcelas confinadas maiores não irão introduzir condições artificiais no sistema solo-planta. Como 
alternativa, parcelas sem barreiras físicas podem ser utilizadas. Porém, é necessário saber quão pequena pode ser a parcela antes que o movimento lateral introduza erros significativos e, obviamente, isso varia com fatores de solo e de clima (Sanchez et al., 1987) e, talvez, com o manejo da pastagem (Martha Júnior, 2000).

Quando parcelas de campo sem área de descarte são escolhidas, o fertilizante marcado é aplicado em uma área pequena dentro de uma parcela maior, sendo que o fertilizante não marcado, aplicado em dose equivalente, é distribuído na área adjacente à área que recebeu fertilizante enriquecido $\operatorname{com}{ }^{15} \mathrm{~N}$. A amostragem de forragem é feita a partir de uma área maior do que aquela adubada com fertilizante marcado e assume-se que essa área de amostragem é suficientemente grande para incluir qualquer ${ }^{15} \mathrm{~N}$ que possa ter se movido para fora da área que originalmente recebeu o fertilizante marcado (Powlson \& Barraclough, 1993).

A maior parte dos experimentos que utilizaram fertilizante $-{ }^{15} \mathrm{~N}$ em pastagens tropicais valeu-se de parcelas confinadas. Dois experimentos com Chloris gayana (capim de Rhodes), no entanto, usaram parcelas de campo sem área de descarte (Henzell, 1971; Vallis et al., 1973). Essa abordagem é aceitável para experimentos com plantas de porte pequeno, como o capim de Rhodes, mas o custo de ${ }^{15} \mathrm{~N}$ para plantas de porte maior ou que se apresentam mais espaçadas no campo, como plantas da espécie $P$. maximum, pode ser proibitivo, mesmo considerando o uso de fertilizante marcado com baixo enriquecimento de ${ }^{15} \mathrm{~N}(<2$ a $3 \%$ de átomos em abundância).

Uma segunda opção para parcelas de campo seria a utilização de parcelas com área de descarte. Para a maioria das culturas o ideal seria aplicar $0{ }^{15} \mathrm{~N}$ em uma área grande em comparação com o porte e espaçamento das plantas no campo e proceder a amostragem apenas no centro dessa área (Powlson \& Barraclough, 1993). Essa prática tem gerado resultados positivos para diversas culturas, como o milho, o trigo e a cana-deaçúcar e, também, para plantas forrageiras de porte pequeno, como o azevém perene Lolium perenne - (Olson, 1980; Powlson et al., 1986; Sanchez et al., 1987; Follet et al., 1991; Geens et al., 1991; Trivelin et al., 1994b). Entretanto, para plantas de porte grande e que se apresentam espaçadas no campo, pode ser que seja possível adubar apenas uma planta (ou touceira) com ${ }^{15} \mathrm{~N}$ (Powlson \& Barraclough, 1993).

Em razão das dificuldades experimentais de se trabalhar com plantas de maior porte, seria particularmente interessante que estudos envolvendo essas espécies forrageiras considerassem o tamanho mínimo adequado da parcela, em diferentes épocas do ano e condições de manejo da pastagem, para evitar o efeito de bordadura. Nesse 
contexto, o presente experimento foi delineado para determinar o tamanho adequado da parcela em experimentos com Panicum maximum cv. Tanzânia, adubado com fertilizante-

${ }^{15} \mathrm{~N}$ em diferentes épocas do ano e manejado sob três intensidades de desfolha.

\subsection{Material e Métodos}

O experimento foi realizado em pastagem estabelecida de $P$. maximum cv. Tanzânia, localizada em área experimental da Escola Superior de Agricultura "Luiz de Queiroz", Universidade de São Paulo, Piracicaba-SP (altitude 580 m; 2241'30" S; 47³8'00" W). O solo, um Podzólico Vermelho-escuro (Argissolo vermelho) de textura argilosa, apresentava $33 \%$ de areia, $23 \%$ de silte e $44 \%$ de argila, sendo as características químicas da camada superficial $\left(0\right.$ a $20 \mathrm{~cm}$ ) descritas por: $\mathrm{pH}_{\mathrm{cacl} 2}=5,2$; matéria orgânica $24 \mathrm{~g} / \mathrm{dm}^{3} ; \mathrm{P}$ (resina) - $17 \mathrm{mg} / \mathrm{dm}^{3} ; \mathrm{K}-3,9 \mathrm{mmol}_{\mathrm{c}} / \mathrm{dm}^{3} ; \mathrm{Ca}-44 \mathrm{mmol} / \mathrm{dm}^{3} ; \mathrm{Mg}-16$ $\mathrm{mmol}_{\mathrm{d}} / \mathrm{dm}^{3} ; \mathrm{Al}-1 \mathrm{mmol}_{\mathrm{d}} / \mathrm{dm}^{3} ; \mathrm{e} \mathrm{H}+\mathrm{Al}-38 \mathrm{mmol}_{\mathrm{C}} / \mathrm{dm}^{3}$.

A pastagem foi irrigada (pivô central) para atingir a capacidade de campo quando tensiômetros instalados na profundidade de $20 \mathrm{~cm}$ indicaram potencial de água no solo de $-0,03$ a -0,04 MPa (Lourenço \& Coelho, 2000). A Tabela 1 apresenta detalhes de algumas características do clima durante os períodos experimentais.

Tabela 1. Condições climáticas médias durante os experimentos de inverno, primavera e verão.

\begin{tabular}{lcccc}
\hline \multicolumn{1}{c}{ Estação/mês } & $\begin{array}{c}\text { Radiac̃ão } \\
\text { (cal//cm } 2 \text { /dia) }\end{array}$ & $\begin{array}{c}\text { Insolação } \\
\text { (horas/dia) }\end{array}$ & \multicolumn{2}{c}{ Memperatura $\left({ }^{\circ} \mathrm{C}\right)$} \\
& & & & \\
$\quad$ Inverno & & & & \\
Junho & 304 & 6,7 & 11,4 & 19,3 \\
Julho & 320 & 6,5 & 8,8 & 16,6 \\
& & & & \\
Primavera/Verão & 480 & 7,2 & 18,0 & 25,0 \\
Outubro & 465 & 6,8 & 17,7 & 23,8 \\
Novembro & 448 & 5,6 & 19,0 & 24,4 \\
Dezembro & 509 & 7,4 & 19,6 & 25,8 \\
Janeiro & & & & \\
\hline
\end{tabular}

Três experimentos foram realizados, correspondendo às épocas de inverno (de 2 de junho a 7 de julho), de primavera (de 24 de outubro a 25 de dezembro) e de verão (de 29 de novembro a 30 de janeiro). No experimento de inverno, utilizou-se um delineamento 
inteiramente casualizado com cinco repetições. Para os experimentos de primavera e de verão, o delineamento foi em blocos completos casualizados com quatro repetições.

Os tratamentos foram representados por três intensidades de pastejo (intenso, moderado e leniente), determinadas pela massa de forragem residual. No inverno, os resíduos pós-pastejo foram de $816,2.548$ e $3.113 \mathrm{~kg} / \mathrm{ha}$ de massa seca verde (MSV) nos pastejos intenso, moderado e leniente, respectivamente. Na primavera e no verão, as respectivas massas de forragem residuais foram de $1.210,3.036$ e $5.471 \mathrm{~kg} / \mathrm{ha}$ de MSV (Penati, 2002). Adotou-se um ciclo de pastejo de 36 dias, consistindo de um período de pastejo de três dias e um período de descanso de 33 dias.

As parcelas consistiram de grupos de microparcelas não confinadas de 1 $\mathrm{m}^{2}$, inseridas dentro de parcelas maiores, de $4 \mathrm{~m}^{2}$. As parcelas de 1 e de $4 \mathrm{~m}^{2}$ tiveram uma touceira do capim em seu centro geométrico (Figura 1). A área interna, de $1 \mathrm{~m}^{2}$, foi adubada com sulfato de amônio enriquecido com fertilizante- ${ }^{15} \mathrm{~N}\left(3 \%\right.$ de átomos de ${ }^{15} \mathrm{~N}$ em excesso), mas a área adjacente externa, de $3 \mathrm{~m}^{2}\left(4 \mathrm{~m}^{2}-1 \mathrm{~m}^{2}\right)$, foi fertilizada com $\left(\mathrm{NH}_{4}\right)_{2} \mathrm{SO}_{4}$ comercial (Figura 1). O fertilizante marcado foi aplicado às microparcelas por meio de $500 \mathrm{~mL}$ de solução seguida por $500 \mathrm{~mL}$ de água. O fertilizante não marcado, na forma de grânulo, foi aplicado no restante da parcela $\left(3 \mathrm{~m}^{2}\right)$. O fertilizante nitrogenado, em dose equivalente a $80 \mathrm{~kg} / \mathrm{ha}$ de $\mathrm{N}$, foi aplicado à pastagem dois dias depois da saída dos animais do piquete. Detalhes adicionais da área experimental foram apresentados por Penati (2002).

As touceiras existentes nos $4 \mathrm{~m}^{2}$ foram contadas, cortadas ao nível do solo e a distância do centro da área basal das plantas amostradas na área externa $\left(3 \mathrm{~m}^{2}\right)$, até o "border" (i.e. limite) da área adubada com fertilizante- ${ }^{15} \mathrm{~N}$, foi registrada. No experimento de inverno, a forragem foi cortada depois de 30 dias da aplicação do fertilizante nitrogenado, enquanto que nos experimentos de primavera e verão, o corte de avaliação foi feito 27 dias depois da adubação. As amostras colhidas no campo foram pesadas, subamostradas, pesadas novamente e secas em estufa com ventilação forçada de $\operatorname{ar}\left(60^{\circ} \mathrm{C}\right.$ por 72 horas). Subseqüentemente, as amostras foram pesadas e moídas $(1 \mathrm{~mm})$. O teor de $\mathrm{N}$ total e a abundância isotópica de ${ }^{15} \mathrm{~N}$ nas amostras foram determinados em espectrômetro de massa automatizado para análise de carbono e N (ANCA-MS SL 20-20, Europa Scientific; Barrie \& Prosser, 1996). O nitrogênio proveniente do fertilizante marcado (Npfm), como porcentagem do $\mathrm{N}$ total na planta, foi calculado pela eq. (1).

$\mathrm{Npfm}=(\mathrm{a} \div \mathrm{b}) \times 100$ 
em que "a" e "b" representam o excesso de ${ }^{15} \mathrm{~N}$ (\% de átomos de ${ }^{15} \mathrm{~N}$ em excesso) na planta e no fertilizante, respectivamente. O valor-base de ${ }^{15} \mathrm{~N}$ na planta foi de $0,3663 \%$.

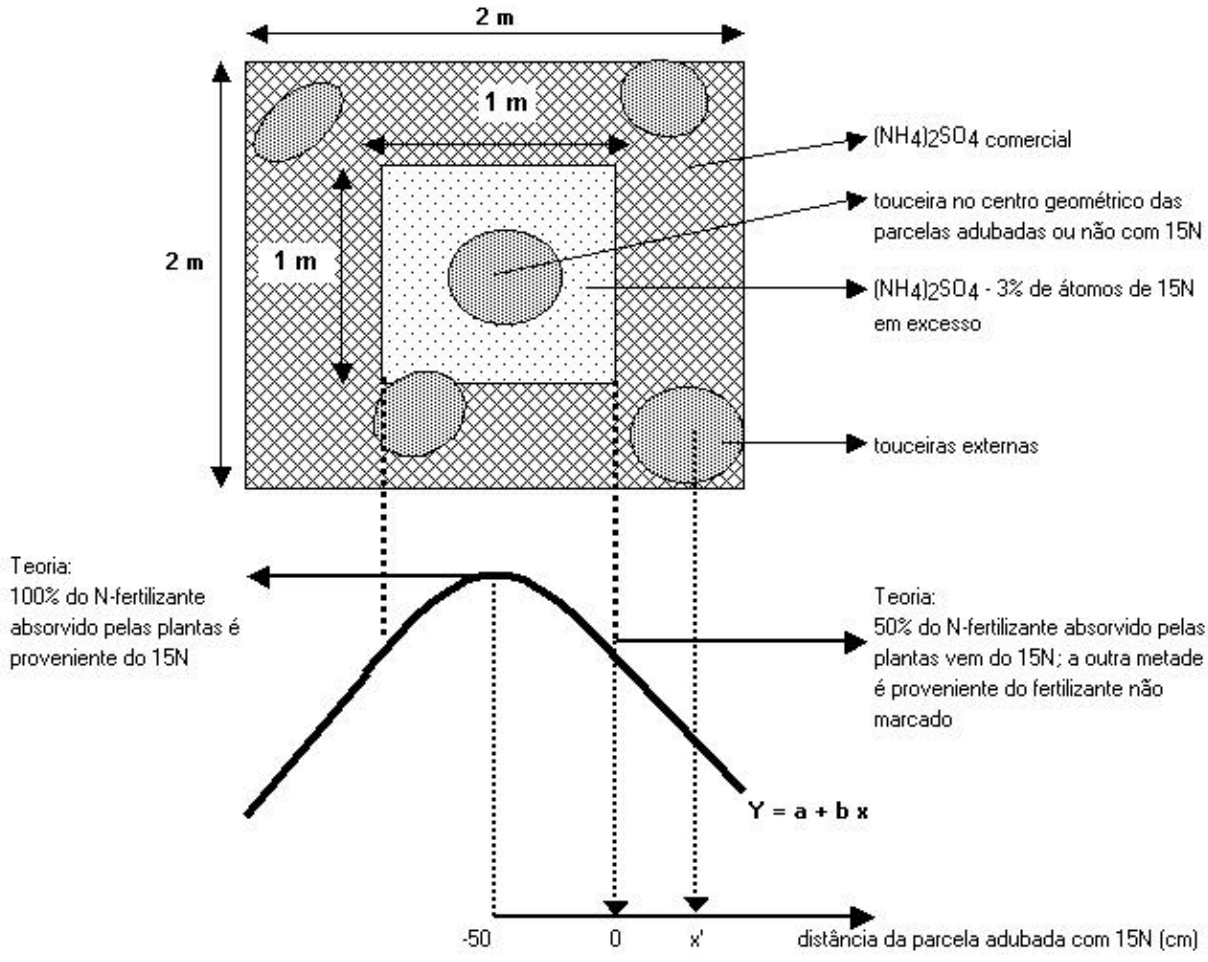

Figura 1 - Esquema de parcelas adubadas com fertilizante- ${ }^{15} \mathrm{~N}$ e utilizadas para a determinação do tamanho da parcela. $\mathrm{Na}$ parte inferior da Figura é apresentada a teoria do experimento, de acordo com Sanchez et al. (1987) e Trivelin et al. (1994b).

$\mathrm{Na}$ teoria, uma planta posicionada exatamente no limite das áreas adubadas com fertilizante marcado e comercial absorveria metade do seu $\mathrm{N}$ da parcela que recebeu ${ }^{15} \mathrm{~N}(1$ $\mathrm{m}^{2}$ ) e a outra metade viria do $\mathrm{N}$ do fertilizante com abundância natural $\left(3 \mathrm{~m}^{2}\right)$, como indicado na Figura 1. A fração relativa $(Y)$ do $\mathrm{Npfm}$ entre plantas amostradas a uma distância " $\mathrm{x}$ " do limite da área adubada com fertilizante- ${ }^{15} \mathrm{~N}\left(\mathrm{Npfm}_{\mathrm{x}}\right)$, em relação às plantas posicionadas no centro de uma parcela adubada com fertilizante marcado de tamanho infinito (Npdm $\mathrm{C}_{\mathrm{c}}$; plantas posicionadas dentro da parcela fertilizada com ${ }^{15} \mathrm{~N}$ sem a ocorrência de efeito de bordadura) pode ser determinada pela eq. (2). 
$\mathrm{Y}=\mathrm{Npfm}_{\mathrm{x}} \div \mathrm{Npfm}_{\mathrm{c}}$

$\mathrm{Na}$ ausência de movimento lateral do fertilizante, as curvas indicando o enriquecimento isotópico na planta, em função de sua posição, deveriam ser simétricas em relação ao limite da parcela. A ausência de simetria em relação ao limite das parcelas adubadas e não adubadas com ${ }^{15} \mathrm{~N}$ seria evidência de que ocorreu movimento lateral do fertilizante ou que o tamanho da parcela adubada com ${ }^{15} \mathrm{~N}$ foi muito pequeno (Sanchez et al., 1987). Partindo da suposição de que a absorção de ${ }^{15} \mathrm{~N}$ pelas plantas posicionadas a uma dada distância na área externa $\left(3 \mathrm{~m}^{2}\right)$ é equivalente à absorção do $\mathrm{N}$ do fertilizante comercial em distância equivalente, porém, no interior da área adubada com fertilizante marcado, pode-se testar se o tamanho da parcela e da área amostrada são adequados e, se necessário, correções podem ser feitas (Sanchez et al., 1987; Powlson \& Barraclough, 1993; Trivelin et al., 1994b).

Sanchez et al. (1987) consideraram que a distribuição no enriquecimento isotópico em plantas localizadas em diferentes posições nas áreas adubadas e não adubadas com fertilizante- ${ }^{15} \mathrm{~N}$ seguiria uma curva sigmoidal, eq. (3). Entretanto, uma aproximação linear do modelo de Sanchez et al. (1987) pode ser utilizada (Trivelin et al., 1994b).

$\mathrm{Y}=\left(\mathrm{Npfm}_{\mathrm{x}} \div \mathrm{Npfm}_{\mathrm{c}}\right)=1 \div[1+\exp (\mathrm{px})]$

onde p é um parâmetro, constante para um dado sistema, e " $x$ " é a distância $(\mathrm{cm})$ do limite da área fertilizada com ${ }^{15} \mathrm{~N}$ (negativo ou positivo dependendo da posição, isto é, dentro e fora da parcela adubada com fertilizante marcado, respectivamente.

Análises de regressão linear da fração relativa do $\mathrm{Npfm}\left(\mathrm{Npfm}_{\mathrm{x}} / \mathrm{Npfm}_{\mathrm{c}}\right)$ em relação à distância da parcela adubada com o fertilizante marcado foram realizadas para testar a simetria em relação ao limite das parcelas adubadas e não adubadas com ${ }^{15} \mathrm{~N}$. Procedeuse, então, análises de regressão linear entre o Npfm calculado pelo modelo em função da distância da área adubada com ${ }^{15} \mathrm{~N}$. Posteriormente, por meio do teste "t" de Student (nível de significância de 5\%), comparou-se as médias de $\mathrm{Npfm}_{\mathrm{c}}$ e 2*Npfm 0 (i.e. distância "zero", correspondendo a uma planta posicionada exatamente sobre o "border" das áreas adubada e não adubada com ${ }^{15} \mathrm{~N}$ ). As análises de variância e de regressão e o teste "t" foram feitas com o pacote estatístico SAS System (SAS, 1989). 


\subsection{Resultados e Discussão}

\subsubsection{Massa da touceira}

O aumento na intensidade de pastejo determinou redução na massa da touceira, independentemente da estação do ano (Figura 2). Diversos fatores podem ter contribuído para o balanço de carbono na planta ter ficado negativo por um maior período de tempo durante a fase de rebrota, o que, por sua vez, determinou menor massa de forragem da touceira quando as plantas foram submetidas ao pastejo intenso. Como possíveis fatores, tem-se (Gomide et al., 1979; Chacón-Moreno et al., 1995; Herling et al., 1995; Lemaire, 1997; Pagotto, 2001): 1) a reduzida interceptação de luz, uma vez que a maior parte da área foliar em plantas da espécie $P$. maximum está concentrada no estrato intermediário e superior da touceira; 2) a reduzida capacidade fotossintética, porque as folhas velhas (menos eficientes na fixação do carbono quando comparadas às folhas jovens) encontramse preferencialmente posicionadas na base da touceira; 3) os reduzidos níveis de reservas fisiológicas; e 4) o menor crescimento/atividade de raízes sob desfolha intensa.

Em todas as intensidades de pastejo e épocas do ano houve um padrão quadrático de resposta na massa das touceiras através das áreas adubadas e não adubadas $c o m{ }^{15} \mathrm{~N}$. Plantas nas parcelas adubadas com fertilizante- ${ }^{15} \mathrm{~N}$ e em distâncias maiores do que 40 a $50 \mathrm{~cm}$ dessa área, tiveram maior massa do que as plantas localizadas em distâncias intermediárias (Figura 2). De maneira geral, observou-se compensação completa na massa das touceiras (kg MS/touceira) na área da parcela considerada ( $4 \mathrm{~m}^{2}$; Figura 2). Essa compensação na massa das touceiras não foi verificada no pastejo intenso, durante a avaliação de verão, e no pastejo leniente, na primavera. Possivelmente, o estabelecimento do início do processo de degradação da pastagem, no primeiro caso, e a renovação da população de perfilhos, no segundo, explicam esses resultados, conforme se depreende dos trabalhos de Penati (2002) e de Santos (2002), respectivamente. Entretanto, não se pode descartar a hipótese de que a resposta compensatória na massa das touceiras poderia ocorrer em maiores distâncias (maior superfície de amostragem) do que as avaliadas nesses estudos.

O padrão espacial observado no tamanho das touceiras aparentemente não está relacionado com a adubação. Pelo contrário, esse comportamento parece ser uma característica inerente ao capim Tanzânia, sendo verificado uma compensação entre massa e número de touceiras em uma área de $4 \mathrm{~m}^{2}$ (Figura 3). 

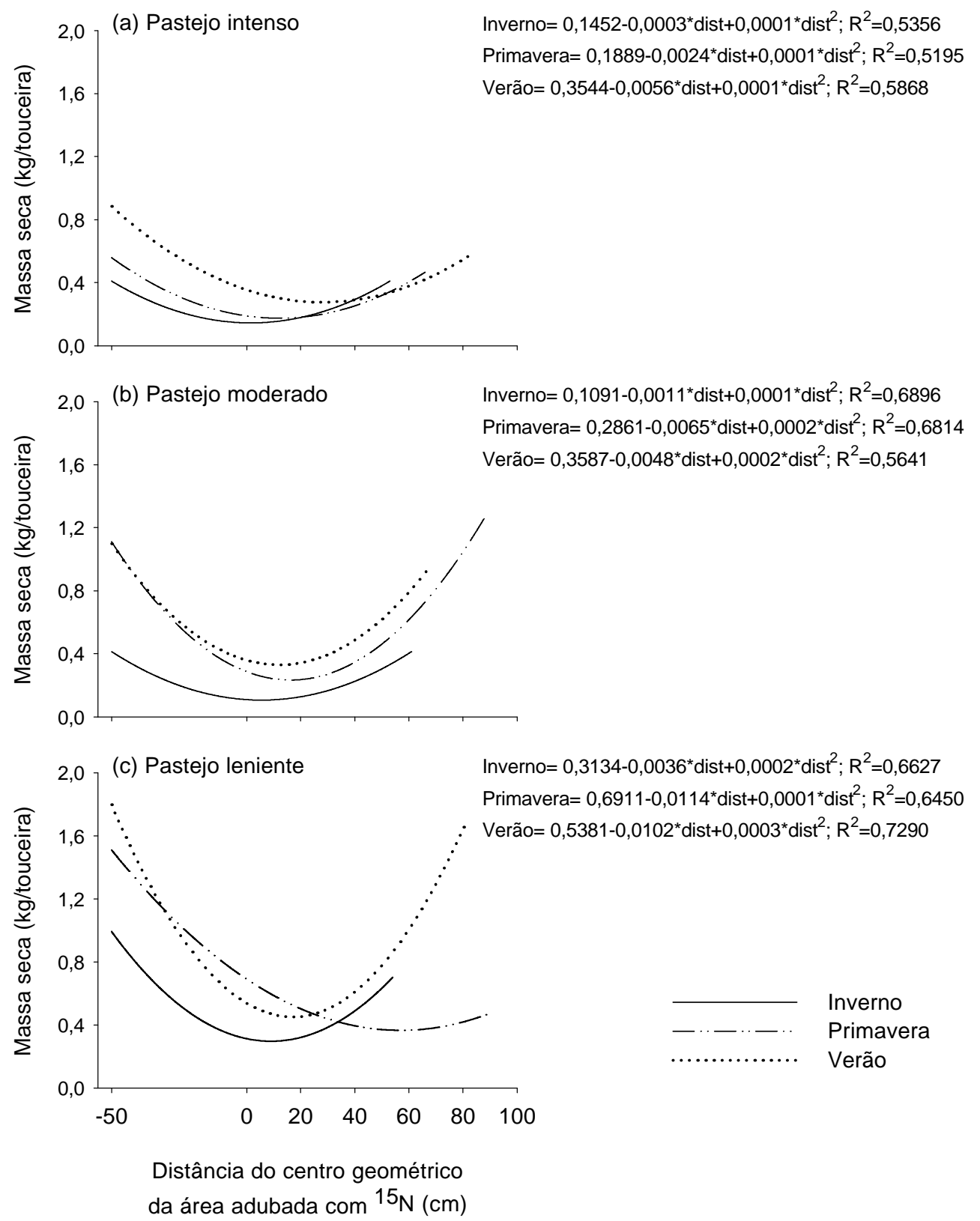

Figura 2 - Variabilidade espacial na massa da touceira de $P$. maximum cv. Tanzânia, em diferentes épocas do ano, em função da intensidade de pastejo: intenso (a), moderado (b) e leniente (c). As equações apresentadas são significativas $(\mathrm{P}<0,02)$. 

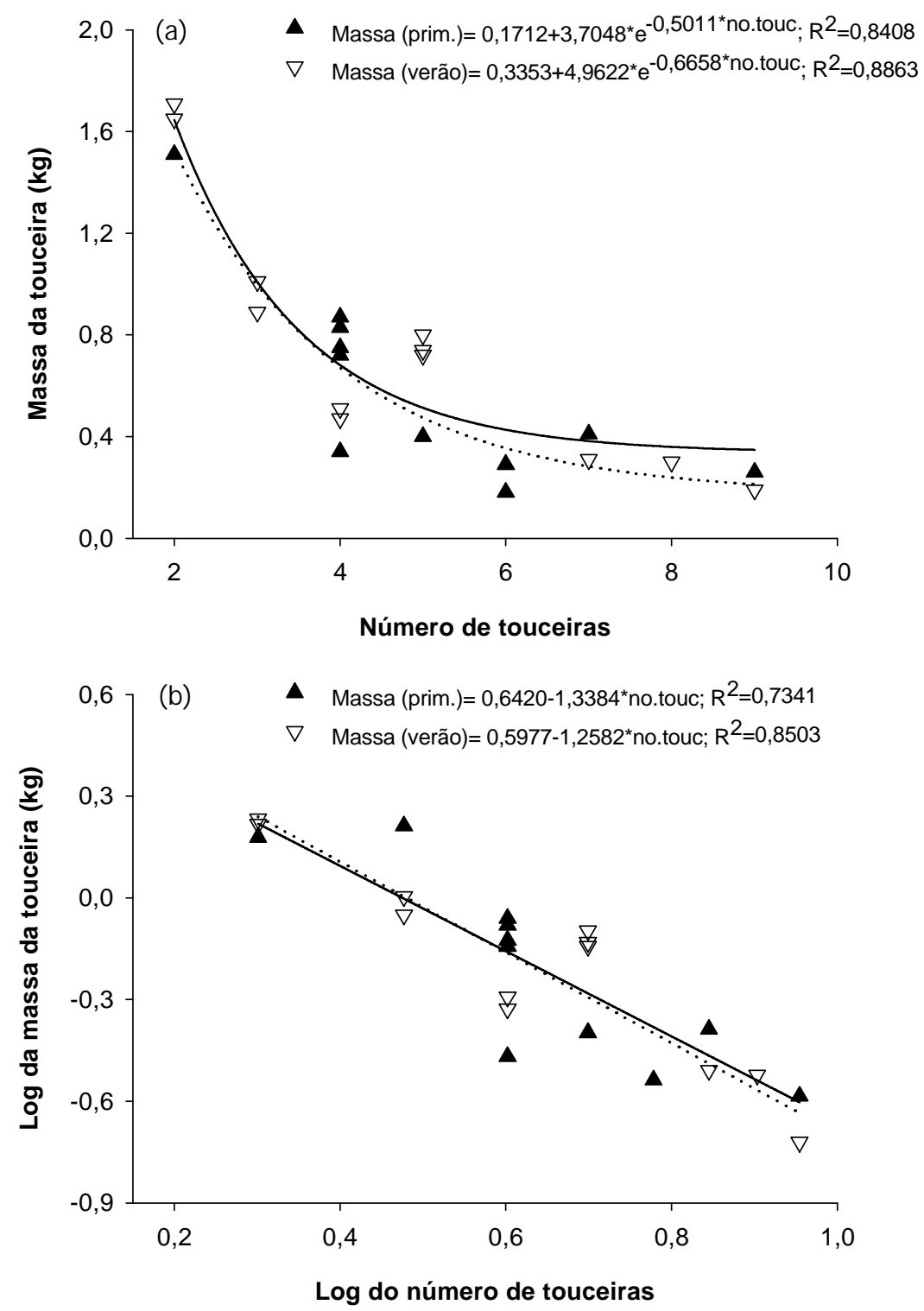

Figura 3 - Relação entre massa e número de touceira em uma área de $4 \mathrm{~m}^{2}$ em $P$. maximum cv. Tanzânia na primavera e no verão. As equações apresentadas são significativas $(\mathrm{P}<0,002)$.

O comportamento exponencial entre esses fatores (Figura 3a) provavelmente explica a ausência de efeito significativo entre a massa e o número de touceiras no inverno $(P>0,05)$, época do ano em que a amplitude na massa das touceiras foi menor. Ademais, é 
interessante notar que a resposta observada na Figura 3 contrasta com aquela obtida em pastagens de clima temperado, em que a compensação entre o tamanho e o número ocorre ao nível de perfilhos (Matthew et al., 1995). Assim, enquanto a compensação entre o tamanho e o número de perfilhos em pastagens de $P$. maximum tem sido inconsistente (Herling et al., 1998; 1999; Santos, 2002), os coeficientes angulares das retas de compensação entre o tamanho e o número de touceiras apresentados na Figura 3b, de $2,7 / 2$ e $-2,5 / 2$, são próximos à curva teórica de auto-desbaste com inclinação $-3 / 2$ (Matthew et al., 1995).

O padrão espacial na massa das touceiras em função da distância da área adubada com fertilizante- ${ }^{15} \mathrm{~N}$ abre espaço para pelo menos duas questões para trabalhos futuros com Panicum maximum cv. Tanzânia. A primeira é sobre a eficiência de uso do fertilizante nitrogenado aplicado ao pasto na forma líquida (parcela adubada com ${ }^{15} \mathrm{~N}$ ) ou sólida (parcela adubada com fertilizante comercial). Watson et al. (1992) observaram que a aplicação superficial de uréia em pastagem de azevém perene, na forma líquida, não resultou em menores perdas de amônia por volatilização em comparação com a uréia aplicada em forma granulada. De maneira semelhante, Volk (1959) encontrou que as perdas de $\mathrm{N}$-uréia aplicada superficialmente em pastagem de Cynodon dactylon, na forma de solução, foi similar às perdas da uréia aplicada na forma de grânulo. Portanto, parece que a forma de aplicação do fertilizante nitrogenado não interferiu de maneira significativa sobre a eficiência de uso do $\mathrm{N}$ do fertilizante pelas plantas forrageiras e, conseqüentemente, não teve efeito sobre as respostas observadas na massa das touceiras nesse estudo.

Uma segunda questão diz respeito ao uso de linhas transectas como método para avaliações agronômicas em pastagens de $P$. maximum cv. Tanzânia. A reproduzível variabilidade espacial na massa das touceiras, tanto entre tratamentos como entre épocas do ano, pode indicar que, dependendo do ponto inicial em que as avaliações (massa de forragem, perfilhamento, etc.) baseadas na linha transecta são tomadas, é possível a introdução de erros sistemáticos nessas determinações. Possivelmente, esses erros sistemáticos irão variar com o manejo da pastagem e com a estação do ano, porque o padrão de variação na massa da touceira entre as intensidades de pastejo e as épocas do ano pode ser o mesmo, mas as características absolutas, conforme demonstrado pela massa das touceiras, variam consideravelmente com a intensidade de desfolha e com a época do ano (Figura 2). Essa constatação ratifica a necessidade de mais estudos sobre a estratégia de amostragem de forragem, visando contemplar, de maneira satisfatória, os 
Parcelas menores do que $1 \mathrm{~m}^{2}$ não foram testadas, mas é possível que, com plantas menores (i.e. pastejo intenso), o tamanho da parcela possa ser inferior a $1 \mathrm{~m}^{2}$. Entretanto, a possibilidade de trabalhar com parcelas menores é questionável, uma vez que, sob pastejo intenso, verificou-se sinais de degradação da pastagem (Penati, 2002).

O declínio nos valores de Npfm com o aumento da distância da área adubada com

${ }^{15} \mathrm{~N}$ é coerente com trabalhos realizados com milho (Sanchez et al., 1987) e com cana-deaçúcar (Trivelin et al., 1994b). No trabalho com cana-de-açúcar, em particular, Trivelin et al. (1994b) encontraram decréscimo de 0,6 a 2,0 unidades percentuais no Npfm para cada 10 $\mathrm{cm}$ de aumento na distância da área adubada com ${ }^{15} \mathrm{~N}$. Esses valores são consistentes com as taxas de declínio no Npfm verificadas nesse estudo, de 0,76 a 2,66 para cada incremento de $10 \mathrm{~cm}$ na distância da área adubada com fertilizante- ${ }^{15} \mathrm{~N}$ (Tabela 2). Não foi encontrado nenhum outro trabalho com pastagem de gramínea tropical delineado para acessar as exigências quanto ao tamanho da parcela. Todavia, a redução na abundância de ${ }^{15} \mathrm{~N}$ com o aumento na distância da área adubada com o traçador foi relatada por Vallis et al. (1973), em estudo com capim de Rhodes.

O declínio no Npfm, com o aumento na distância da área adubada com fertilizante marcado, significa que o movimento lateral do $\mathrm{N}$ do fertilizante e/ou a distribuição lateral das raízes concentraram-se nas proximidades da área adubada com ${ }^{15} \mathrm{~N}$. Como as touceiras posicionadas nas proximidades desse limite foram menores do que as plantas vizinhas (Figura 2), numa dada intensidade de pastejo, o padrão de declínio no Npfm com o aumento na distância da área adubada com ${ }^{15} \mathrm{~N}$ pode ser conseqüência de uma competição desvantajosa entre plantas de diferentes tamanhos. Vale lembrar que essa disposição espacial das plantas parece ser uma característica inerente à pastagem de capim Tanzânia.

De maneira geral, observou-se maiores taxas de declínio no valor de Npfm com o aumento da distância da área adubada com fertilizante marcado no pastejo intenso e menores no pastejo leniente, sendo as taxas de declínio do pastejo moderado intermediárias às encontradas para o pastejo intenso e leniente (Tabela 2). Esse fato indica que plantas submetidas a desfolhas mais lenientes foram capazes de absorver o $\mathrm{N}$ em maiores distâncias da área adubada com ${ }^{15} \mathrm{~N}$, possivelmente em razão de serem mais vigorosas (Figura 2) e, conseqüentemente, mais capacitadas para expressar maior crescimento e atividade de raízes do que as plantas submetidas ao pastejo intenso (Dawson et al., 2000; Corsi et al., 2001b; Pagotto, 2001), em especial na primavera e no verão (Tabela 2). $\mathrm{O}$ maior potencial de absorção de $\mathrm{N}$ do solo nos pastejos moderado e 
leniente, em razão do maior crescimento de raízes (Pagotto, 2002), em associação com o maior potencial de utilização de reservas fisiológicas, nessas condições (Thorton \& Millard, 1996; Louahlia et al., 2000), pode explicar os menores valores médios de Npfm nos pastejos moderado e leniente em comparação à desfolha intensa (Tabela 2). Depreendese, dessa assertiva, que com maior intensidade de pastejo as plantas tornam-se mais dependentes da adubação nitrogenada.

Finalmente, é importante mencionar que o uso de parcelas de $1 \mathrm{~m}^{2}$ para condições de pastagens de sequeiro pode não ser necessariamente adequado, em razão de diferenças na disponibilidade de água no solo e na distribuição e atividade de raízes e, conseqüentemente, no movimento lateral do fertilizante nitrogenado entre condições irrigadas e de sequeiro. No entanto, é provavelmente seguro sugerir que para locais (ou anos) com chuvas em quantidades adequadas e bem distribuídas para atender 0 crescimento da forragem, parcelas de $1 \mathrm{~m}^{2}$ poderiam ser utilizadas sem risco de comprometer os resultados de recuperação do fertilizante- ${ }^{15} \mathrm{~N}$ por pastagens não irrigadas de P. maximum cv. Tanzânia. Com efeito, Adegbola \& Adepoju (1983) determinaram, para uma região úmida na Nigéria, que as raízes de $P$. maximum não irrigado tiveram distribuição lateral de cerca de $45 \mathrm{~cm}$, o que indica que parcelas de $1 \mathrm{~m}^{2}$ poderiam ser utilizadas para locais com essas características.

\subsection{Conclusões}

O aumento na intensidade de pastejo determinou redução na massa da touceira e, quanto menor a touceira, maior foi a sua dependência no nitrogênio do fertilizante. Assim, em sistemas de pastejo operando com desfolhas intensas, a adubação nitrogenada deve ser priorizada. A recuperação do fertilizante- ${ }^{15} \mathrm{~N}$ por pastagem irrigada de capim Tanzânia pode ser acessada de maneira segura por parcelas não confinadas de $1 \mathrm{~m}^{2}$ que apresentam uma touceira do capim em seu centro geométrico. Esse tamanho de parcela mostrou-se válido para o inverno, para a primavera e para o verão. 


\section{RECUPERAÇÃO DO NITROGÊNIO $\left({ }^{15} \mathrm{~N}\right)$ DA URÉIA POR PASTAGEM DE CAPIM TANZÂNIA DURANTE O VERÃO}

\section{Resumo}

O atrativo econômico e o impacto ambiental da adubação nitrogenada de pastagens dependem da eficiência de uso do nitrogênio $(N)$ do fertilizante no sistema soloplanta. Entretanto, o conhecimento sobre a recuperação do ${ }^{15} \mathrm{~N}$-uréia por pastagens de Panicum maximum cv. Tanzânia permanece desconhecido. O presente experimento, seguindo um delineamento de blocos completos casualizados com quatro tratamentos $(0$, 40,80 and $120 \mathrm{~kg} / \mathrm{ha}$ of $\mathrm{N}$-uréia) e três repetições, foi realizado para determinar a recuperação do ${ }^{15} \mathrm{~N}$-uréia pelo capim Tanzânia. A produção de forragem, o teor de $\mathrm{N}$ total e a quantidade de $\mathrm{N}$ na planta não foram afetados pela adubação $(P>0,05)$. A recuperação de ${ }^{15} \mathrm{~N}$-uréia (\% do $\mathrm{N}$ aplicado) na forragem e nas raízes não foi afetada pelos níveis de adubação $(P>0,05)$, mas diminuiu exponencialmente no solo e no sistema solo-planta com 0 aumento nos níveis de uréia $(P<0,05)$. A quantidade de ${ }^{15} \mathrm{~N}(\mathrm{~kg} / \mathrm{ha})$ na forragem e nas raízes $(0$ a $15 \mathrm{~cm})$ aumentou com o incremento nas doses de uréia $(P<0,05)$.

\section{UREA NITROGEN $\left({ }^{15} \mathrm{~N}\right)$ RECOVERY BY TANZANIA GRASS PASTURE DURING THE SUMMER}

\section{Summary}

The economical attractiveness and the environmental impact of nitrogen $(\mathrm{N})$ fertilization in pastures depend on the $\mathrm{N}$ use efficiency in the soil-plant system. However, the knowledge about the recovery of urea- ${ }^{15} \mathrm{~N}$ by Panicum maximum $\mathrm{cv}$. Tanzania pastures remains unknown. The present experiment, following a randomized complete block design with four treatments $(0,40,80$ and $120 \mathrm{~kg} / \mathrm{ha}$ of $\mathrm{N}$-urea) and three replicates, was conducted to determine the recovery of urea- ${ }^{15} \mathrm{~N}$ by Tanzania grass. Herbage production, 
total $\mathrm{N}$ content and $\mathrm{N}$ yield were not affected by fertilization $(P>0,05)$. The recovery of urea-

${ }^{15} \mathrm{~N}$ (\% of applied $\left.\mathrm{N}\right)$ in herbage and roots was not affected by fertilization levels $(P>0,05)$, but exponentially decreased in soil and in the soil-plant system $(P<0,05)$ with increasing levels of urea. The amount of ${ }^{15} \mathrm{~N}(\mathrm{~kg} / \mathrm{ha})$ in herbage and in roots $(15$ to $30 \mathrm{~cm})$ increased with increasing urea doses $(P<0,05)$.

\subsection{Introdução}

Diversos estudos mostraram que a adubação nitrogenada pode aumentar a produção de forragem de Panicum maximum (Vicente-Chandler et al., 1974; Crespo, 1986; Lugão, 2001). Entretanto, a economicidade e o impacto ambiental dessa prática dependem, em última análise, da eficiência de uso do nitrogênio $(\mathrm{N})$ do fertilizante pela planta. Assim, a importância de se aprimorar os conhecimentos sobre a dinâmica do $\mathrm{N}$ do fertilizante em ecossistemas de pastagens reside na necessidade de garantir elevada rentabilidade, ao mesmo tempo em que se precisa assegurar que os recursos e a qualidade do ambiente (solo, água e atmosfera) não sejam prejudicados pelas práticas agrícolas, como a adubação nitrogenada de pastagens.

Quando informações mais detalhadas sobre o movimento e sobre as transformações do $\mathrm{N}$ do fertilizante na planta forrageira e no solo são o objetivo do estudo e/ou não existe a possibilidade de se trabalhar com um tratamento controle (sem adubação nitrogenada), a estimativa da recuperação do $\mathrm{N}$ aplicado pelo método isotópico passa a ser uma opção mais interessante do que aquela feita pelo aparente. Todavia, até o momento poucos experimentos de campo foram realizados com gramíneas tropicais e fertilizante- ${ }^{15} \mathrm{~N}$ (Harper et al., 1983; Impithuksa et al., 1984; Impithuksa \& Blue, 1985; Martha Júnior, 1999; Oliveira, 2001), não havendo, ainda, nenhum estudo que tenha considerado o uso de fertilizante- ${ }^{15} \mathrm{~N}$ em pastagem de $P$. maximum cv. Tanzânia, uma das principais opções para sistemas de produção animal em pastejo com elevado uso de insumos. Nesse contexto, o presente estudo teve o objetivo de estimar a recuperação de ${ }^{15} \mathrm{~N}$-uréia por pastagem de capim Tanzânia durante o verão.

\subsection{Material e Métodos}

O experimento foi realizado em pastagem irrigada de Panicum maximum cv. Tanzânia, estabelecida em área experimental da Escola Superior de Agricultura "Luiz de 
Queiroz", Universidade de São Paulo, Piracicaba-SP (altitude $580 \mathrm{~m}$; 22 ${ }^{\circ} 41^{\prime} 30^{\prime \prime}$ S; 47 38 '00" W), durante um ciclo de pastejo de verão (06/01/02 a 11/02/02). O delineamento experimental foi em blocos completos casualizados, com quatro tratamentos $(0,40,80 \mathrm{e}$ $120 \mathrm{~kg} / \mathrm{ha}$ de N-uréia) e três repetições.

As características climáticas médias, durante o período experimental, podem ser descritas por: temperaturas mínima, média e máxima de $19,0^{\circ} ; 24,2^{\circ}$ e $29,5^{\circ} \mathrm{C}$, respectivamente; umidade relativa do ar de $87,4 \%$; evaporação de 5,4 $\mathrm{mm} /$ dia e velocidade do vento de $6,3 \mathrm{~km} / \mathrm{h}$. No período, as chuvas totalizaram $411 \mathrm{~mm}$. Durante o experimento, a umidade do solo, na camada de 0 a $20 \mathrm{~cm}$ de profundidade, representou 90 a $105 \%$ da capacidade de campo. Por ocasião da instalação dos tratamentos (adubação nitrogenada), verificou-se que, na superfície, o solo mostrava-se encharcado (presença de poças d'água).

O solo da área experimental, classificado como Podzólico Vermelho-escuro (Argissolo vermelho) de textura argilosa, apresentava 33\% de areia, $23 \%$ de silte e $44 \%$ de argila na camada de 0 a $20 \mathrm{~cm}$ de solo. A saturação por bases e os outros elementos minerais no solo foram corrigidos para os níveis sugeridos por Corsi \& Nussio (1993), com base na análise química do solo. A correção e a adubação do solo foram feitas para se atingir $70 \%$ de saturação por bases, $20 \mathrm{mg} / \mathrm{dm}^{3}$ de $\mathrm{P}$ no solo e proporção de $\mathrm{K}$ no solo equivalente a $4-5 \%$ da CTC. As características químicas do solo $(0-20 \mathrm{~cm})$ podem ser descritas por: matéria orgânica - $25 \mathrm{~g} / \mathrm{kg} ; \mathrm{pH}\left(\mathrm{CaCl}_{2}\right)-5,1 ; \mathrm{P}$ (resina) - 19,1 mg/ $\mathrm{dm}^{3} ; \mathrm{K}-$ 4,2 $\mathrm{mmol}_{\mathrm{c}} / \mathrm{dm}^{3} ; \mathrm{Ca}-41 \mathrm{mmol}_{\mathrm{d}} / \mathrm{dm}^{3} ; \mathrm{Mg}-21 \mathrm{mmol} / \mathrm{dm}^{3} ; \mathrm{H}+\mathrm{Al}-35 \mathrm{mmol}_{\mathrm{d}} / \mathrm{dm}^{3}$.

Parcelas não confinadas de $1 \times 1 \mathrm{~m}$, apresentando uma touceira do capim em seu centro geométrico, foram aleatoriamente locadas em um piquete de $1.333 \mathrm{~m}^{2}$. O manejo da pastagem consistiu de três dias de ocupação e 33 dias de descanso, sendo o resíduo póspastejo de cerca de $3.500 \mathrm{~kg} / \mathrm{ha}$ de massa seca verde. Para assegurar a distribuição uniforme do fertilizante, o ${ }^{15} \mathrm{~N}$-uréia, de acordo com os tratamentos, foi aplicado à parcela por meio de solução (500 mL da solução contendo o fertilizante seguida por mais $500 \mathrm{~mL}$ de água) na manhã do dia subseqüente àsaída dos animais do piquete.

Nas touceiras, que representaram a área vegetada da pastagem, estudou-se o efeito de doses crescentes de $\mathrm{N}$-uréia sobre a recuperação do fertilizante- ${ }^{15} \mathrm{~N}$. Depois de 1 , 6, 10 e 30 dias da adubação, mediu-se a altura das plantas, do nível do solo até a inflexão da folha mais alta da planta. Ao final do período de crescimento (30 dias depois da adubação nitrogenada), os seguintes componentes da pastagem foram avaliados: estrato superior (parte aérea); resíduo pós-pastejo; sistema radicular e solo (média de duas 
subamostras), nas camadas de 0 a 15 e 15 a $30 \mathrm{~cm}$ de profundidade. $O$ estrato superior correspondeu àforragem cortada acima de $40 \mathrm{~cm}$ do solo, que representava a altura média do resíduo. A forragem compreendida do nível do solo à altura de $40 \mathrm{~cm}$ representou 0 resíduo pós-pastejo. No momento do corte da forragem amostrou-se, em cada parcela, o sistema radicular das plantas e o componentes solo com sonda de 7,5 cm de diâmetro, em dois pontos (subamostras) na touceira, uma região central e outra mais próxima à extremidade. A massa seca de todos os componentes foi determinada em estufa com ventilação forçada de $\operatorname{ar}\left(60^{\circ}, 72\right.$ horas) e os valores resultantes foram expressos em $\mathrm{kg} / \mathrm{ha}$ de massa seca.

Em cada um dos componentes, determinou-se o teor de nitrogênio total e a abundância isotópica de ${ }^{15} \mathrm{~N}$ em espectrômetro de massa automatizado para análise de carbono e nitrogênio (ANCA SL-20 20, Europa Scientific; Barrie \& Prosser, 1996). O produto entre a massa seca do componente e o seu respectivo valor de $\mathrm{N}$ total representou a quantidade de $\mathrm{N}(\mathrm{QN}, \mathrm{kg} / \mathrm{ha})$. O nitrogênio proveniente do fertilizante marcado ( $\mathrm{Npfm})$ foi calculado pela eq. (1).

$\mathrm{Npfm}=(a \div b) \times 100$

em que "a" e "b" representam o excesso de ${ }^{15} \mathrm{~N}$ (\% de átomos de ${ }^{15} \mathrm{~N}$ em excesso) na planta ou no solo e no fertilizante, respectivamente. Os valores-base de ${ }^{15} \mathrm{~N}$ na planta e no solo foram de $0,3663 \%$ e $0,3685 \%$ de átomos em excesso, respectivamente.

As recuperações percentuais de ${ }^{15} \mathrm{~N}\left(\mathrm{R}^{15} \mathrm{~N}\right)$, na planta ou no solo, expressos em relação ao $\mathrm{N}$ aplicado, foram calculadas pela eq. (2). A quantidade de ${ }^{15} \mathrm{~N}$-uréia recuperada, num dado componente, considerou os valores de $\mathrm{R}^{15} \mathrm{~N}$ e a quantidade de $\mathrm{N}$ na adubação.

$\mathrm{R}^{15} \mathrm{~N}=\{(\mathrm{Npfm} \times \mathrm{QN}$ no componente $) \div$ Dose de $\mathrm{N}$-fertilizante $\} \times 100$

A recuperação aparente do $\mathrm{N}$ aplicado foi determinada pela diferença do $\mathrm{N}$ absorvido entre as plantas de parcelas adubadas e não adubadas para uma dada dose de $\mathrm{N}$-fertilizante. 
Os dados foram testados quanto à normalidade dos erros e homogeneidade de variâncias e as análises estatísticas foram feitas com os recursos do pacote estatístico SAS System (SAS, 1989).

\subsection{Resultados e Discussão}

A adubação nitrogenada não teve efeito sobre a produção de massa seca da parte aérea e do sistema radicular ( $P>0,05$; Figuras 1a,b), contrariando as informações da literatura de que a aplicação de $\mathrm{N}$ promove acréscimos na massa seca de $P$. maximum (Vicente-Chandler et al., 1974; Crespo, 1986; Lugão et al., 2001). Esse fato explica a ausência de resposta na altura das plantas em razão dos diferentes níveis de adubação $(P>0,05)$. Entretanto, a altura da pastagem aumentou em taxas decrescentes ao longo do período de rebrota ( $\mathrm{P}<0,05$; Figura 2), refletindo a disposição decumbente das folhas do capim Tanzânia (Jank et al., 1994). O hábito decumbente das folhas, em associação com a relativa estabilização da altura das plantas a partir de 20 dias depois da adubação (Figura 2), indicam limitações ao manejo do capim Tanzânia baseado na entrada dos animais no piquete quando a pastagem atingir uma determinada altura.

$\mathrm{O}$ uso de fertilizante nitrogenado não alterou o teor de $\mathrm{N}$ total ou a quantidade de $\mathrm{N}$ na planta $(P>0,05$; Figuras 1c,d,e,f), o que também não era esperado (Vicente-Chandler et al., 1974; Crespo, 1986). A baixa eficiência agronômica da uréia pode ser atribuída às elevadas perdas do $\mathrm{N}$ aplicado (capítulo 7). A baixa recuperação de ${ }^{15} \mathrm{~N}$-uréia no sistema solo-planta, principalmente nos maiores níveis de fertilizante nitrogenado, dá suporte a essa idéia (Figuras 3 e 4). Tomando como referência a dose de $40 \mathrm{~kg} / \mathrm{ha}$ de $\mathrm{N}$-uréia, calcula-se, pela equação apresentada na Figura 3d, que, no intervalo de adubação testado, houve redução de quatro vezes no ${ }^{15} \mathrm{~N}$-uréia recuperado no sistema solo-planta. Esse comportamento ajuda a explicar a falta de resposta às doses crescentes de uréia sobre a produção de forragem, o teor de $\mathrm{N}$ total e a quantidade de $\mathrm{N}$ na planta (Figura 1).

Quando a recuperação de ${ }^{15} \mathrm{~N}$-uréia foi expressa em termos do percentual do $\mathrm{N}$ aplicado, não se verificou efeito $(P>0,05)$ da dose de uréia sobre a recuperação do fertilizante- ${ }^{15} \mathrm{~N}$ na parte aérea (estrato superior e resíduo pós-pastejo) e no sistema radicular (0 a 15 e 15 a $30 \mathrm{~cm}$ ) (Figuras 3a,b). 

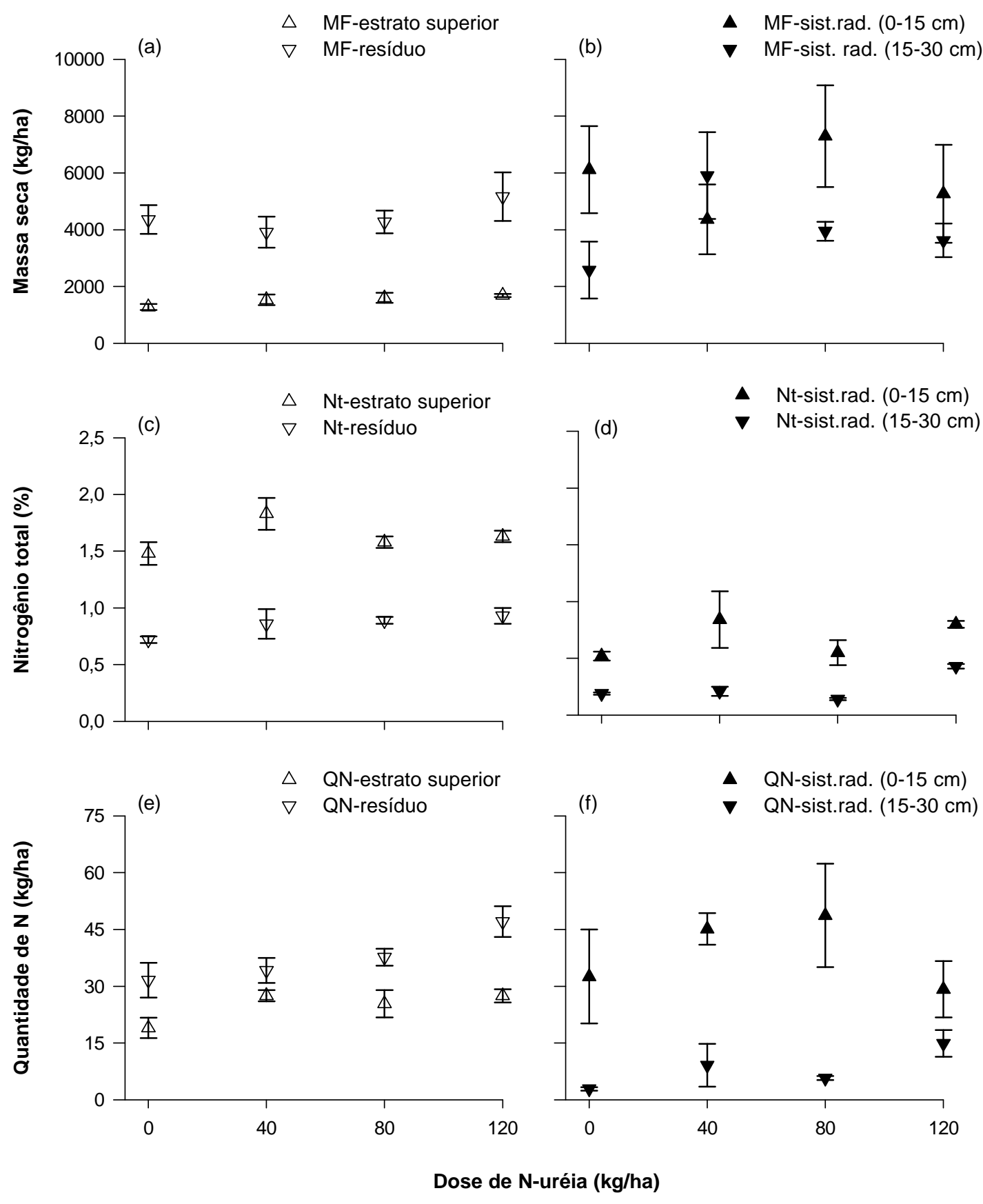

Figura 1 - Produção de massa seca de forragem (MF), teor de nitrogênio total (Nt) e quantidade de nitrogênio (QN) na parte aérea (estrato superior e resíduo póspastejo) e sistema radicular (profundidades de 0-15 e 15-30 cm) de capim Tanzânia adubado com 0, 40, 80 e 120 kg/ha de N-uréia. 


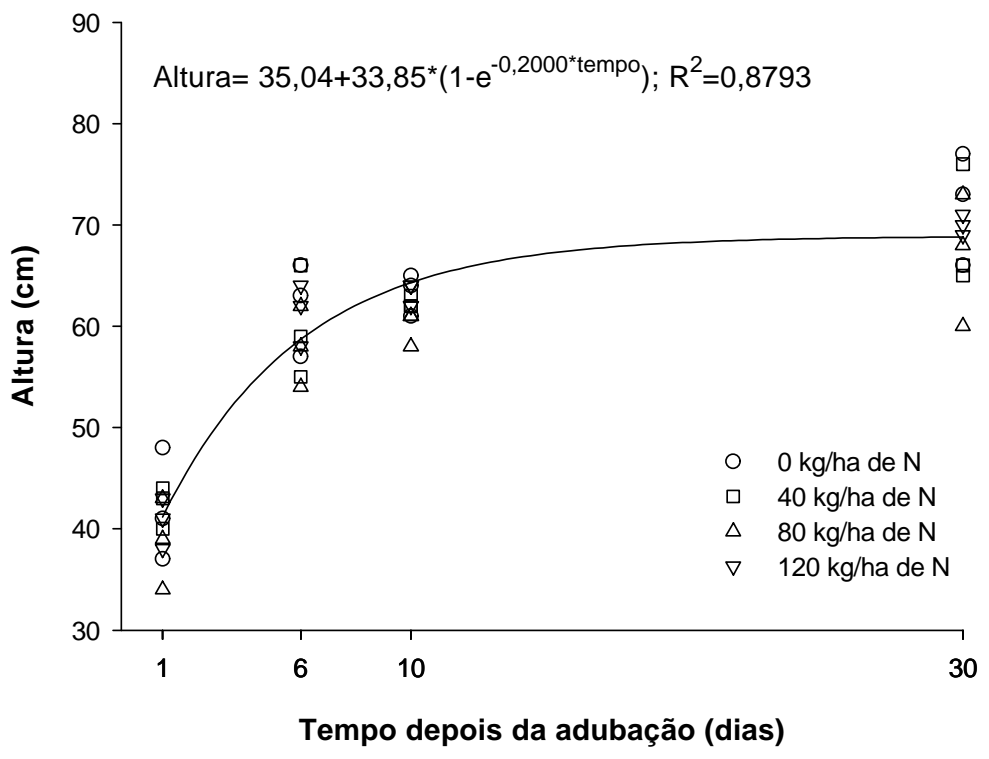

Figura 2 - Altura (cm) da pastagem em função de adubações com 0, 40, 80 e $120 \mathrm{~kg} / \mathrm{ha}$ de $\mathrm{N}$-uréia. A equação apresentada é significativa $(\mathrm{P}<0,0001)$.

A ausência de efeito da dose do fertilizante nitrogenado sobre a recuperação percentual do fertilizante- ${ }^{15} \mathrm{~N}$ na biomassa vegetal também foi observada por outros autores (Henzell, 1971; Impithuksa et al., 1984; Impithuksa \& Blue, 1985). Todavia, o aumento na dose de uréia determinou maiores $(P<0,05)$ quantidades de ${ }^{15} \mathrm{~N}(\mathrm{~kg} / \mathrm{ha})$ na parte aérea e no sistema radicular (camada de 15 a $30 \mathrm{~cm}$ ) da pastagem, porém, esses acréscimos foram de pequena magnitude (Figuras 4a,b).

Ressalta-se que a recuperação percentual de ${ }^{15} \mathrm{~N}$, medida no presente estudo, foi bastante inferior à relatada nos poucos experimentos com pastagens tropicais. Em revisão sobre a recuperação de fertilizante- $-{ }^{15} \mathrm{~N}$ na parte aérea de gramíneas tropicais, verificou-se um valor médio de recuperação de $30 \%$ do $\mathrm{N}$ aplicado (Tabela 2 do capítulo 2), cerca de três vezes superior aos valores indicados na Figura $3 a$.

Desse modo, parece que a planta não teve condições apropriadas para absorver o $\mathrm{N}$ do fertilizante e translocá-lo para a parte aérea. Possivelmente, a baixa recuperação de ${ }^{15} \mathrm{~N}$ na biomassa vegetal pode ter sido conseqüência: 1) das elevadas perdas do $N$ aplicado que aconteceram nos primeiros dias depois da adubação, que reduziram a quantidade do $\mathrm{N}$ proveniente do fertilizante no solo passível de ser absorvido pelas plantas 
(capítulo 7); e 2) da elevada competição pelo $\mathrm{N}$-mineral que existe entre os microorganismos do solo e as plantas, especialmente no curto-prazo (Hodge et al., 2000), o que prejudica, ainda mais, a capacidade da planta em absorver o $\mathrm{N}$ disponível do solo. No entanto, não se pode descartar a hipótese de que o efeito residual das adubações nitrogenadas realizadas nos ciclos de pastejo anteriores tenha diminuído a eficiência do $\mathrm{N}$ aplicado no período estudado.

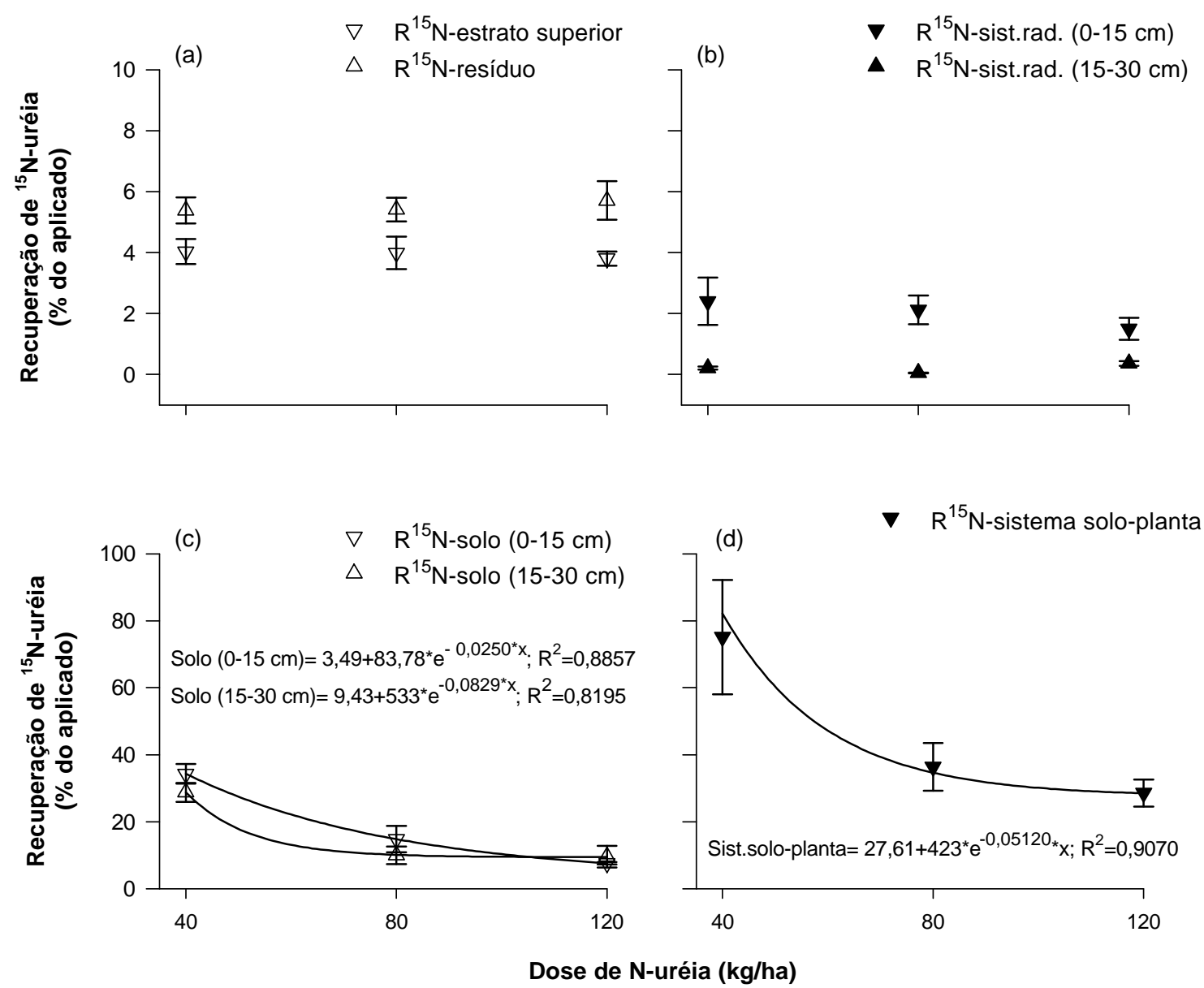

Figura 3 - Recuperação de fertilizante- ${ }^{15} \mathrm{~N}$ (\% do $\mathrm{N}$ aplicado) nos componentes da pastagem de capim Tanzânia adubada com 40, 80 e 120 kg/ha de N-uréia. As equações apresentadas são significativas $(P<0,05)$.

Westerman \& Kurtz (1974) e Rao et al. (1992) indicaram que a estimativa de recuperação aparente do $\mathrm{N}$ aplicado é maior do que aquela obtida pelo uso do traçador 
${ }^{15} \mathrm{~N}$. Esse fato reflete a pressuposição do método de recuperação aparente, de que os processos fisiológicos das plantas e as transformações do $\mathrm{N}$ no solo são similares nas condições de presença e ausência de adubação, o que não é verdade (Jenkinson et al., 1985; Hart et al., 1986). Entretanto, apenas na dose de $120 \mathrm{~kg} / \mathrm{ha}$ de $\mathrm{N}$-uréia observou-se diferenças nas estimativas de recuperação do $\mathrm{N}$ aplicado na parte aérea por esses dois métodos (Figura 5). A maior precisão na estimativa de recuperação do $\mathrm{N}$ aplicado, pelo método isotópico (Figura 5), encontra suporte nos trabalhos de Westerman \& Kurtz (1974) e Rao et al. (1992).
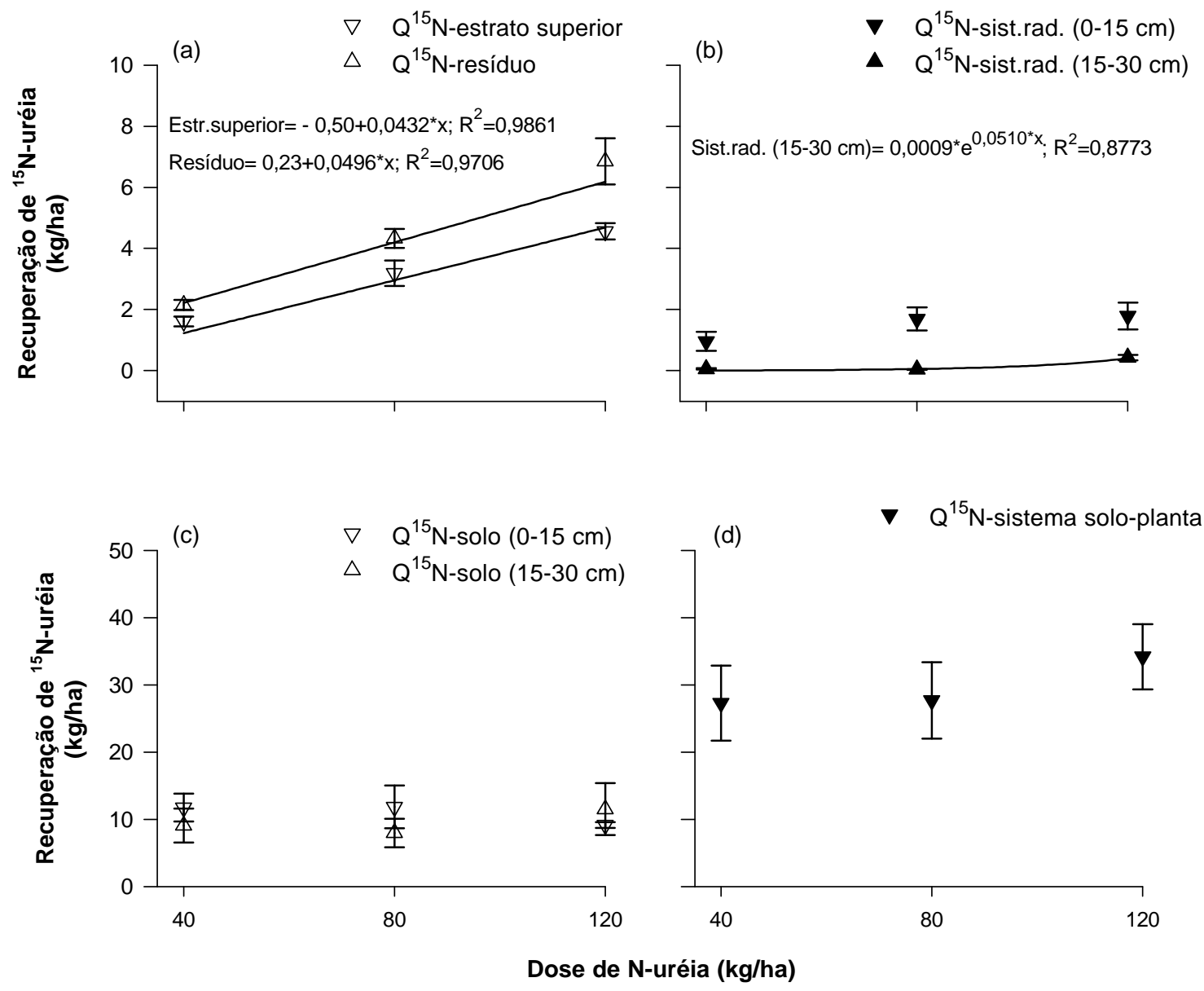

Figura 4 - Recuperação de fertilizante- ${ }^{15} \mathrm{~N}(\mathrm{~kg} / \mathrm{ha})$ nos componentes da pastagem de capim Tanzânia adubada com 40, 80 e 120 kg/ha de N-uréia. As equações apresentadas são significativas $(\mathrm{P}<0,001)$. 


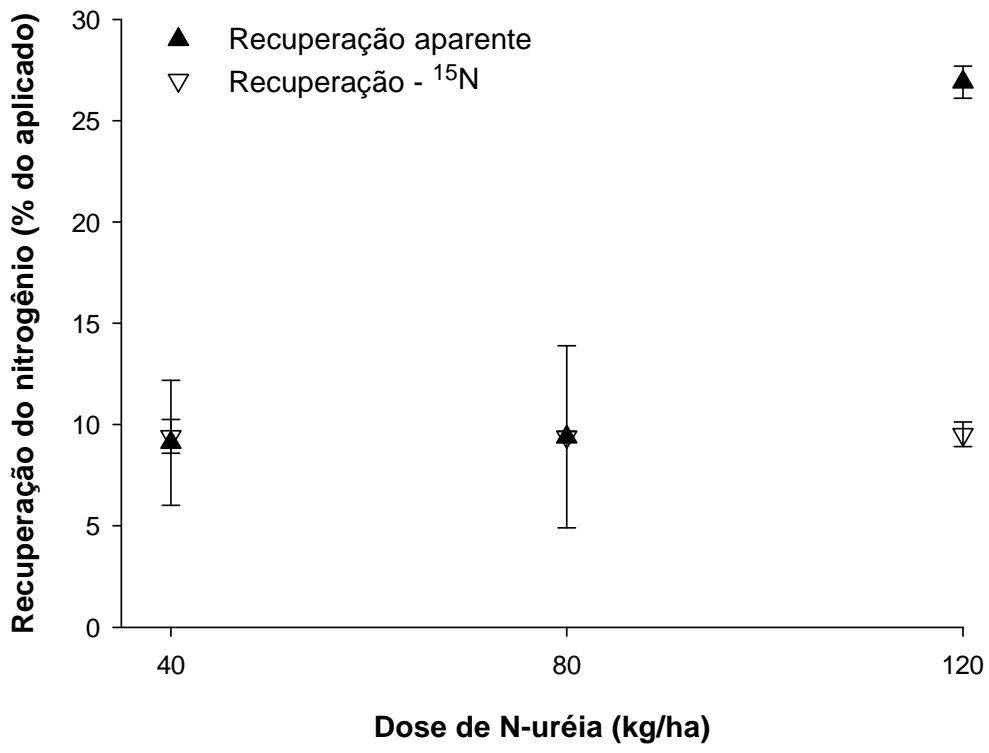

Figura 5 - Estimativa da recuperação percentual do nitrogênio aplicado, na parte aérea de capim Tanzânia adubado com 40, 80 e 120 kg/ha de N-uréia, pelos métodos aparente e isotópico.

A dose do fertilizante nitrogenado teve efeito significativo $(P<0,05)$ sobre a recuperação de ${ }^{15} \mathrm{~N}$ no componente solo. $\mathrm{Na}$ amplitude das doses testadas, e tendo como referencial a dose de $40 \mathrm{~kg} / \mathrm{ha}$ de $\mathrm{N}$-uréia, calcula-se, pelas equações apresentadas na Figura 3c, que o aumento na adubação nitrogenada promoveu redução de 2,0 e de 6,6 vezes na recuperação de ${ }^{15} \mathrm{~N}$-uréia nas camadas de 0 a 15 e de 15 a $30 \mathrm{~cm}$ de solo, respectivamente.

Pode-se inferir que, em adição às perdas gasosas (capítulo 7), o decréscimo na recuperação do fertilizante- ${ }^{15} \mathrm{~N}$ no solo, nas maiores doses do fertilizante (Figura $3 \mathrm{c}$ ), foi resultado de incrementos nas perdas por lixiviação em decorrência das chuvas no período $\left(411 \mathrm{~mm}\right.$ ) e da camada de solo estudada (até $30 \mathrm{~cm}$ ). Entretanto, o ${ }^{15} \mathrm{~N}$-uréia perdido da camada superficial pode ser absorvido pela planta em camadas mais profundas do solo. Bartholomew (1971) observou absorção do $\mathrm{N}$ do fertilizante até $163 \mathrm{~cm}$ de profundidade do solo. Verifica-se, ainda, que a quantidade $(\mathrm{kg} / \mathrm{ha})$ do $\mathrm{N}$ do fertilizante no solo não diferiu nas adubações com 40, 80 e 120 kg/ha de N-uréia (Figura 4c). 


\subsection{Conclusões}

A produção de forragem, o teor de nitrogênio total e a quantidade de nitrogênio do capim Tanzânia não responderam à adubação nitrogenada. A baixa eficiência agronômica do uso da uréia pode ser explicada pelo decréscimo da recuperação do nitrogênio do fertilizante (\% do $\mathrm{N}$ aplicado) no sistema solo-planta com o aumento na dose de $\mathrm{N}$-uréia. 


\section{PERDA DE AMÔNIA POR VOLATILIZAÇÃO EM PASTAGEM DE CAPIM TANZÂNIA ADUBADA COM URÉIA NO VERÃO}

\section{Resumo}

Parte do nitrogênio $(\mathrm{N})$ do fertilizante aplicado à pastagem pode ser perdida do sistema e, em pastagens tropicais, a volatilização de amônia $\left(\mathrm{NH}_{3}\right)$ é uma das principais vias de perda. $\mathrm{O}$ presente estudo teve o objetivo de estimar a perda de $\mathrm{N}-\mathrm{NH}_{3}$ por volatilização em pastagem de Panicum maximum cv. Tanzânia adubada com uréia durante o verão. Adotou-se um delineamento de blocos completos casualizados com medidas repetidas no tempo e três repetições. Nas parcelas, encontravam-se as doses de N-uréia (40, 80 e $120 \mathrm{~kg} / \mathrm{ha}$ de N-uréia) e, nas subparcelas, o período depois da adubação (1, 5 e 9 dias). A interação entre o nível de adubação e o período depois da aplicação de uréia foi significativa $(\mathrm{P}<0,01)$ para as variáveis volatilização acumulada de $\mathrm{N}-\mathrm{NH}_{3}$ e taxa diária de volatilização de $\mathrm{N}-\mathrm{NH}_{3}$. A combinação de elevada umidade do solo, ausência de chuvas durante o primeiro dia depois da adubação e temperatura elevada determinaram elevadas perdas de amônia por volatilização. A perda acumulada de $\mathrm{N}-\mathrm{NH}_{3}$ em nove dias depois da adubação representou 48, 41 e 42\% do $\mathrm{N}$ aplicado nas adubações com 40, 80 e $120 \mathrm{~kg} / \mathrm{ha}$ de $\mathrm{N}$-uréia, respectivamente. A volatilização acumulada de $\mathrm{N}-\mathrm{NH}_{3}(\mathrm{~kg} / \mathrm{ha})$ aumentou $(\mathrm{P}<0,05)$ enquanto a taxa diária de volatilização de $\mathrm{N}-\mathrm{NH}_{3}$ diminui $(\mathrm{P}<0,05)$ com o aumento do tempo depois da adubação.

\section{AMMONIA VOLATILIZATION LOSS IN TANZANIA GRASS PASTURE FERTILIZED WITH UREA IN THE SUMMER}

\section{Summary}

Part of the fertilizer nitrogen $(\mathrm{N})$ applied to pasture may be lost from the system and, in tropical pastures, the volatilization of ammonia $\left(\mathrm{NH}_{3}\right)$ is one of the major pathways of 
loss. The present study aimed to estimate the $\mathrm{NH}_{3}-\mathrm{N}$ volatilization loss in Panicum maximum cv. Tanzania pasture fertilized with urea during the summer. A complete randomized block design in a repeated measures arrangement with three replicates was adopted. In the plots were the urea doses (40, 80 and $120 \mathrm{~kg} / \mathrm{ha}$ urea-N) while the time after fertilization (1, 5 and 9 days) represented the subplots. The interaction between the level of fertilization and the time after urea application was significant $(P<0,01)$ for accumulated $\mathrm{NH}_{3}-\mathrm{N}$ volatilization loss and daily $\mathrm{NH}_{3}-\mathrm{N}$ volatilization loss rate. The combination of high soil water content, lack of rainfall in the day following fertilization and high temperature determined high ammonia volatilization losses. The accumulated $\mathrm{NH}_{3}-\mathrm{N}$ loss after nine days from fertilization represented 48,41 and $42 \%$ of the applied $\mathrm{N}$ in 40,80 and $120 \mathrm{~kg} / \mathrm{ha}$ urea- $\mathrm{N}$ fertilizations, respectively. The accumulated $\mathrm{NH}_{3}-\mathrm{N}$ loss $(\mathrm{kg} / \mathrm{ha})$ increased $(P<0,05)$ while the daily $\mathrm{NH}_{3}-\mathrm{N}$ volatilization loss rate decreased $(P<0,05)$ with the increase in time from fertilization.

\subsection{Introdução}

Parte do nitrogênio $(\mathrm{N})$ do fertilizante aplicado à pastagem é freqüentemente perdida do sistema, o que reduz a eficiência de uso do $\mathrm{N}$ aplicado e, potencialmente, diminui a lucratividade dos empreendimentos de pecuária baseados na exploração de pastagens adubadas com fertilizantes nitrogenados. Em pastagens tropicais, a volatilização de amônia $\left(\mathrm{NH}_{3}\right)$ é uma das principais vias de perda, principalmente quando a uréia é aplicada a lanço e em cobertura no final das chuvas (Martha Júnior, 1999; Primavesi et al., 2001). Embora a incorporação de uréia ao solo a 4 a $5 \mathrm{~cm}$ de profundidade seja efetiva na redução das perdas de $\mathrm{N}-\mathrm{NH}_{3}$ por volatilização (Ernst \& Massey, 1960; Hargrove, 1988), essa prática não é recomendada para pastagens cespitosas, porque prejudica o sistema radicular da planta forrageira, diminuindo o vigor de rebrota subseqüente da pastagem (Corsi \& Nussio, 1993; Corsi et al., 2001b). Porém, no Brasil, os fertilizantes nitrogenados são normalmente aplicados em cobertura, sem incorporação no solo.

Desse modo, é necessário desenvolver alternativas para reduzir as perdas e para maximizar o uso do $\mathrm{N}$-fertilizante nessas condições. Entretanto, avanços expressivos para o entendimento do ciclo do $\mathrm{N}$ e para o desenvolvimento de protocolos práticos de manejo desse nutriente só serão observados quando estimativas confiáveis da perda do $\mathrm{N}$ aplicado forem conhecidas. Intrínseca à essa argumentação, está a necessidade dessas estimativas serem realizadas em campo, uma vez que os resultados gerados em laboratório ou em 
casa-de-vegetação, ainda que úteis para o entendimento de alguns processos, são de aplicabilidade limitada e contestável para plantas crescendo no campo. Ressalta-se, ainda, o limitado número de estudos realizados no país com esse propósito (Martha Júnior, 1999; Primavesi et al., 2001) e a inexistência de trabalhos com Panicum maximum cv. Tanzânia, forrageira amplamente utilizada em sistemas intensivos de produção de bovinos em pastagem no país.

Nesse contexto, o presente estudo teve o objetivo de estimar as perdas de $\mathrm{N}-\mathrm{NH}_{3}$ por volatilização em pastagem de capim Tanzânia adubada com uréia durante um ciclo de pastejo de verão.

\subsection{Material e Métodos}

O experimento foi realizado em pastagem irrigada de Panicum maximum cv. Tanzânia, estabelecida em área experimental da Escola Superior de Agricultura "Luiz de Queiroz", Universidade de São Paulo, Piracicaba-SP (altitude 580 m; 2241'30" S; 47 $\left.38^{\prime} 00^{\prime \prime} \mathrm{W}\right)$, durante um ciclo de pastejo de verão.

O padrão e a extensão de volatilização de $\mathrm{N}^{-N_{H}}$, em razão de diferentes doses de adubação e de períodos depois da aplicação de uréia, foram avaliados na área não vegetada de parcelas $(1 \mathrm{~m} \times 1 \mathrm{~m})$ distribuídas aleatoriamente em um piquete de $1.333 \mathrm{~m}^{2} . \mathrm{A}$ área não vegetada, que representou $70 \%$ da superfície da pastagem, correspondeu à superfície do solo não ocupada pela área basal das touceiras. No início das avaliações, no dia seguinte à retirada dos animais dos piquetes, a massa de forragem residual foi de aproximadamente $3.500 \mathrm{~kg} / \mathrm{ha}$ de massa seca verde e a altura desse resíduo pós-pastejo foi de cerca de $40 \mathrm{~cm}$. A massa seca de material morto presente na área não vegetada (litter) foi de aproximadamente $1.500 \mathrm{~kg} / \mathrm{ha}$.

O delineamento foi de blocos completos casualizados com medidas repetidas no tempo e três repetições. Nas parcelas, encontravam-se as doses de N-uréia (40, 80 e 120 $\mathrm{kg} / \mathrm{ha}$ de $\mathrm{N}$-uréia) e, nas subparcelas, o período depois da adubação (1, 5 e 9 dias). $\mathrm{O}$ tratamento controle $(0 \mathrm{~kg} / \mathrm{ha}$ de $\mathrm{N})$ foi considerado como branco (i.e., as perdas de $\mathrm{N}-\mathrm{NH}_{3}$ que ocorrem no sistema sem a influência do fertilizante nitrogenado) e usado para corrigir as perdas de $\mathrm{N}_{-} \mathrm{NH}_{3}$ nas adubações com 40, 80 e $120 \mathrm{~kg} / \mathrm{ha}$ de $\mathrm{N}$. Detalhes adicionais do protocolo experimental foram apresentados por Lara Cabezas \& Trivelin (1990) e Lara Cabezas et al. (1999). 
Algumas características do clima, no período correspondente ao experimento de volatilização de $\mathrm{N}^{-\mathrm{NH}_{3}}$ (10/01 a 19/01), são apresentados na Tabela 1. Durante o experimento, a umidade do solo na camada de 0 a $20 \mathrm{~cm}$ de profundidade representou 90 a $105 \%$ da capacidade de campo. Por ocasião da instalação dos tratamentos (adubação nitrogenada; 10/01), verificou-se que, na superfície, o solo mostrava-se encharcado (presença de poças d'água). Detalhes adicionais da área experimental foram apresentados no capítulo 6.

Tabela 1. Condições climáticas durante o período experimental.

\begin{tabular}{lcccccc}
\hline \multicolumn{1}{c}{ Dia } & $\begin{array}{c}\text { Precipitação } \\
(\mathrm{mm})\end{array}$ & $\begin{array}{c}\text { Radiação } \\
\left(\mathrm{cal} / \mathrm{cm}^{2}\right)\end{array}$ & $\begin{array}{c}\text { Umidade relativa } \\
(\%)\end{array}$ & $\begin{array}{c}\text { Evaporação } \\
(\mathrm{mm})\end{array}$ & \multicolumn{2}{c}{ Temperatura $\left({ }^{\circ} \mathrm{C}\right)$} \\
Mínima & Máxima \\
\hline $06 / 01$ & 18,3 & 547 & 88 & 6,2 & 19,7 & 31,8 \\
$07 / 01$ & 3,9 & 222 & 100 & 1,0 & 20,6 & 26,0 \\
$08 / 01$ & 44,0 & 369 & 96 & 6,2 & 20,3 & 31,0 \\
$09 / 01$ & 8,5 & 248 & 98 & 5,7 & 18,5 & 28,8 \\
$10 / 01^{1}$ & 0,0 & 359 & 88 & 4,2 & 18,4 & 29,0 \\
$11 / 01^{2}$ & 0,0 & 227 & 92 & 5,5 & 19,7 & 25,7 \\
$12 / 01$ & 33,2 & 302 & 96 & 5,7 & 19,2 & 27,7 \\
$13 / 01$ & 28,1 & 183 & 100 & 5,3 & 19,0 & 25,1 \\
$14 / 01$ & 6,4 & 306 & 98 & 4,0 & 20,7 & 28,2 \\
$15 / 01^{2}$ & 2,4 & 356 & 97 & 1,3 & 20,2 & 27,4 \\
$16 / 01$ & 0,0 & 326 & 87 & 5,0 & 19,0 & 24,5 \\
$17 / 01$ & 0,0 & 591 & 80 & 8,0 & 13,8 & 28,0 \\
$18 / 01$ & 0,0 & 477 & 82 & 2,3 & 16,6 & 26,9 \\
$19 / 01^{2}$ & 2,7 & 364 & 92 & 5,1 & 16,7 & 25,3 \\
\hline 1
\end{tabular}

${ }^{1}$ - Aplicação do fertilizante nitrogenado. ${ }^{2}$ - Determinação da volatilização de $\mathrm{NH}_{3}$.

O solo da área experimental era um Podzólico Vermelho-Escuro (Argissolo vermelho) de textura argilosa, cujas principais características químicas podem ser descritas como: matéria orgânica - $25 \mathrm{~g} / \mathrm{kg}$; $\mathrm{pH}\left(\mathrm{CaCl}_{2}\right)$ - 5,1; $\mathrm{P}$ (resina) - 19,1 mg/dm ${ }^{3} ; \mathrm{K}-4,2$ $\mathrm{mmol}_{\mathrm{d}} / \mathrm{dm}^{3} ; \mathrm{Ca}-41 \mathrm{mmol}_{d} / \mathrm{dm}^{3} ; \mathrm{Mg}-21 \mathrm{mmol}_{d} / \mathrm{dm}^{3} ; \mathrm{H}+\mathrm{Al}-35 \mathrm{mmol}_{\mathrm{d}} / \mathrm{dm}^{3}$. A saturação por bases e os outros elementos minerais no solo foram corrigidos, previamente, para os níveis sugeridos por Corsi \& Nussio (1993), com base na análise química do solo. A 
correção e adubação do solo foram feitas para se atingir $70 \%$ de saturação por bases, 20 $\mathrm{mg} / \mathrm{dm}^{3}$ de $\mathrm{P}$ no solo e proporção de $\mathrm{K}$ no solo de 4 a $5 \%$ da CTC.

Uma solução de uréia (500 mL da solução contendo o fertilizante seguida por mais $500 \mathrm{~mL}$ de água), de acordo com os tratamentos, foi aplicada às parcelas no início da manhã do dia seguinte à saída dos animais do piquete (10/01). A eficiência de adubações nitrogenadas na forma líquida e sólida tem sido equiparável. Watson et al. (1992) observaram que a aplicação superficial de uréia em pastagem de Lolium perenne, na forma líquida, não resultou em menores perdas de amônia por volatilização em comparação com a uréia aplicada em forma granulada. De maneira semelhante, Volk (1959) encontrou que as perdas de $\mathrm{N}$-uréia aplicada superficialmente em pastagem de Cynodon dactylon, na forma de solução, foi similar às perdas da uréia aplicada na forma de grânulo.

As medidas de volatilização de $\mathrm{N}-\mathrm{NH}_{3}$ foram realizadas por meio de coletores semiaberto estáticos (Lara Cabezas et al., 1999), que foram locados na área não vegetada da parcela, logo depois da aplicação dos tratamentos. Os coletores de $\mathrm{N}-\mathrm{NH}_{3}$ utilizados nesse experimento foram descritos detalhadamente por Lara Cabezas \& Trivelin (1990). Resumidamente, os coletores consistiram de uma estrutura tubular de PVC transparente flexível $(0,35 \mathrm{~m}$ de altura $\times 0,144 \mathrm{~m}$ de diâmetro interno $\times 1 \mathrm{~mm}$ de espessura) montada sobre suportes de PVC, aleatoriamente colocados na área não vegetada da parcela (dois coletores por parcela) e enterrados no solo a uma profundidade de 3 a $5 \mathrm{~cm}$. Na união do suporte com o coletor utilizou-se massa para calafetar com o objetivo de vedar as superfícies do suporte e do coletor. Esse procedimento teve o objetivo de evitar que o $\mathrm{N}$ $\mathrm{NH}_{3}$ que volatilizava do solo fosse perdido para fora do coletor. Na extremidade oposta ao solo colocou-se um chapéu de PVC transparente para evitar a incidência de chuvas no interior do coletor.

Cada coletor apresentava suportes no seu interior para sustentar duas espumas (densidade $0,02 \mathrm{~g} / \mathrm{cm}^{3}$ ), que antes de serem instaladas nos coletores foram embebidas com $35 \mathrm{~mL}$ de solução de ácido sulfúrico $0,5 \mathrm{~N}$ e glicerina $(3 \% \mathrm{v} / \mathrm{v})$ com o objetivo de

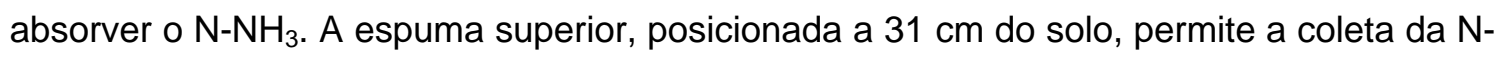
$\mathrm{NH}_{3}$ da atmosfera, evitando que a espuma inferior (15,5 cm do solo), que capta o $\mathrm{N}-\mathrm{NH}_{3}$ volatilizando da superfície do solo, seja contaminada (Lara Cabezas \& Trivelin, 1990). Em cada momento de amostragem, novas espumas embebidas em ácido sulfúrico, conforme indicado acima, foram repostas.

Inicialmente, foram planejadas cinco medidas de volatilização de $\mathrm{N}_{-} \mathrm{NH}_{3}(1,4,7,11$ e 15 dias depois da adubação), porém, em razão das fortes chuvas que ocorreram nos dias 
subsequentes àadubação (Tabela 1), o protocolo de amostragem foi alterado para os dias 1 (11/jan), 5 (15/jan) e 9 (19/jan) depois da adubação, uma vez que chuvas superiores a 10 a $20 \mathrm{~mm}$ reduzem substancialmente o processo de volatilização de $\mathrm{N}-\mathrm{NH}_{3}$ (Black et al., 1987). Depois do segundo período de avaliação, no quinto dia depois da aplicação do fertilizante nitrogenado, repôs-se água dentro dos coletores de $\mathrm{N}-\mathrm{NH}_{3}$, em quantidades equivalentes æ̀ chuvas registradas no período (cerca de $70 \mathrm{~mm}$; Tabela 1), visando evitar erros causados por diferenças na umidade do solo dentro e fora dos coletores, conforme proposto por Lara Cabezas et al. (1999).

Em cada período de coleta, as espumas inferiores, que capturaram $\circ \mathrm{N}^{-\mathrm{NH}_{3}}$ volatilizado do solo, foram acondicionadas em sacos plásticos devidamente identificados, os quais foram vedados e armazenados sob refrigeração até o momento da análise. No laboratório, as espumas foram retiradas individualmente do refrigerador para extração forçada de $\mathrm{N}-\mathrm{NH}_{3}$. Para isso, cada espuma foi colocada sobre um papel de filtro posicionado sobre um funil de porcelana e, com o auxílio de uma bomba de vácuo, lavouse a espuma com aproximadamente $400 \mathrm{~mL}$ de água desionizada. Durante o processo de extração, os materiais que entraram em contato com a espuma também foram lavados com água desionizada para evitar possíveis perdas do $\mathrm{N}^{-\mathrm{NH}_{3}}$ coletado no campo. Além disso, todo o processo foi feito com o auxílio de uma pinça, no sentido de evitar a contaminação do material a ser analisado. Entre a extração de $\mathrm{N}^{-\mathrm{NH}_{3}}$ de duas espumas sucessivas todo o material foi lavado, primeiramente com água de torneira e, subseqüentemente, com água desionizada.

A solução extraída de cada espuma (cerca de 450 a $500 \mathrm{~mL}$ ) foi acidificada com 1 $\mathrm{mL}$ de ácido sulfúrico $1 \mathrm{~N}$ e colocada em um becker para concentrar em estufa à temperatura de $60^{\circ} \mathrm{C}$. Depois de dois dias na estufa, as amostras estavam com volume de cerca de 50 a $70 \mathrm{~mL}$ e, então, foram transferidas para um balão volumétrico de $200 \mathrm{~mL}$ para determinação de $\mathrm{N}-\mathrm{NH}_{3}$. Durante o processo de transferência da solução contendo $\mathrm{N}$ $\mathrm{NH}_{3}$, do becker para o balão volumétrico, lavou-se todos os materiais que entraram em contato com a solução com água desionizada. A determinação de $\mathrm{N}^{-\mathrm{NH}_{3}}$ foi feita por destilação e titulação, sendo que a solução destilada foi recebida em ácido bórico $2 \%$ e titulada com ácido sulfúrico $0,1 \mathrm{~N}$.

Como os coletores estavam posicionados na área da pastagem não ocupada pelas plantas, os resultados foram expressos com base na área não vegetada da pastagem (i.e. $70 \%$ da superfície do pasto), em que a adubação nitrogenada eqüivaleu a 28, 56 e 84 $\mathrm{kg} / \mathrm{ha}$ de $\mathrm{N}$ para os tratamentos adubados com 40, 80 e $120 \mathrm{~kg} / \mathrm{ha}$ de $\mathrm{N}$, respectivamente. 
A perda acumulada de amônia por volatilização $\left(\mathrm{kg} / \mathrm{ha}\right.$ de área não vegetada de $\left.\mathrm{N}-\mathrm{NH}_{3}\right)$ foi calculada a partir de medidas tomadas nos dias 1, 1+5 e 1+5+9. A taxa de perda diária de amônia por volatilização ( $\mathrm{kg} / \mathrm{ha}$ de área não vegetada/dia de $\mathrm{N}-\mathrm{NH}_{3}$ ) foi calculada para todos os períodos (i.e., do dia da adubação ao dia 1, do dia 1 ao dia 5 e do dia 5 ao dia 9).

Uma das principais críticas que coletores fechados e semi-abertos de $\mathrm{N}^{-\mathrm{NH}_{3}}$ recebem diz respeito à geração de condições artificiais no interior do coletor, o que prejudica os fluxos de $\mathrm{N}-\mathrm{NH}_{3}$ da superfície do solo para a atmosfera (Sharpe \& Harper, 1995), podendo ocorrer, inclusive, a reabsorção de $\mathrm{N}-\mathrm{NH}_{3}$ pelo solo. $\mathrm{Na}$ ausência de correção dos valores determinados de $\mathrm{N}-\mathrm{NH}_{3}$, os estudos baseados no uso desses aparelhos não possibilitam quantificar as perdas de $\mathrm{N}-\mathrm{NH}_{3}$ que efetivamente ocorrem no campo. Nesse sentido, as equações de calibração apresentadas por Lara Cabezas et al. (1999), para expressar a volatilização de $\mathrm{N}-\mathrm{NH}_{3}$ em áreas não vegetadas, sem a influência dos coletores (i.e. as perdas reais de $\mathrm{N}-\mathrm{NH}_{3}$ sem a interferência do coletor), foram utilizadas.

Os dados foram testados quanto à normalidade dos erros e homogeneidade de variâncias e as análises estatísticas foram feitas com os recursos do pacote estatístico SAS System (SAS, 1989).

\subsection{Resultados e Discussão}

A interação entre a dose de $\mathrm{N}$-uréia e o período depois da aplicação do adubo foi significativa para as variáveis volatilização acumulada de $\mathrm{N}-\mathrm{NH}_{3}(\mathrm{P}<0,0025)$ e taxa diária de volatilização de $\mathrm{N}-\mathrm{NH}_{3}(\mathrm{P}<0,0001)$. A volatilização acumulada aumentou com o período depois da adubação, apesar das taxas de perda de amônia terem sido decrescentes nesse intervalo. Constatou-se maiores valores de volatilização acumulada ( $\mathrm{kg} / \mathrm{ha})$ nas doses mais elevadas de $\mathrm{N}$-uréia (Figura 1).

Pelos modelos matemáticos apresentados na Figura 1, observa-se que não haveria acúmulo adicional na quantidade de $\mathrm{N}^{-\mathrm{NH}_{3}}$ volatilizada depois de 14, 23 e 35 dias da adubação nos tratamentos fertilizados com 40, 80 e $120 \mathrm{~kg} / \mathrm{ha}$ de N-uréia, respectivamente. Considerando a quantidade de $\mathrm{N}$-uréia aplicada na área não vegetada da pastagem, de 28, 56 e $84 \mathrm{~kg} / \mathrm{ha}$, calcula-se que a perda acumulada de $\mathrm{N}-\mathrm{NH}_{3}$, no período, eqüivaleu a 48,41 e $42 \%$ do $\mathrm{N}$ aplicado, respectivamente.

A ausência de efeito da dose de $\mathrm{N}$-uréia $(\mathrm{P}>0,05)$ sobre a perda de $\mathrm{N}-\mathrm{NH}_{3}$, expressa como \% do N aplicado, encontra suporte nas considerações de Hargrove (1988), 
de que uma vez que a volatilização de $\mathrm{N}-\mathrm{NH}_{3}$ pode ser linear ou exponencial (como observado no padrão de resposta da Figura 1), as perdas relativas (\% do $\mathrm{N}$ aplicado) podem diminuir, permanecerem constantes ou aumentarem com níveis crescentes de aplicação do fertilizante nitrogenado.

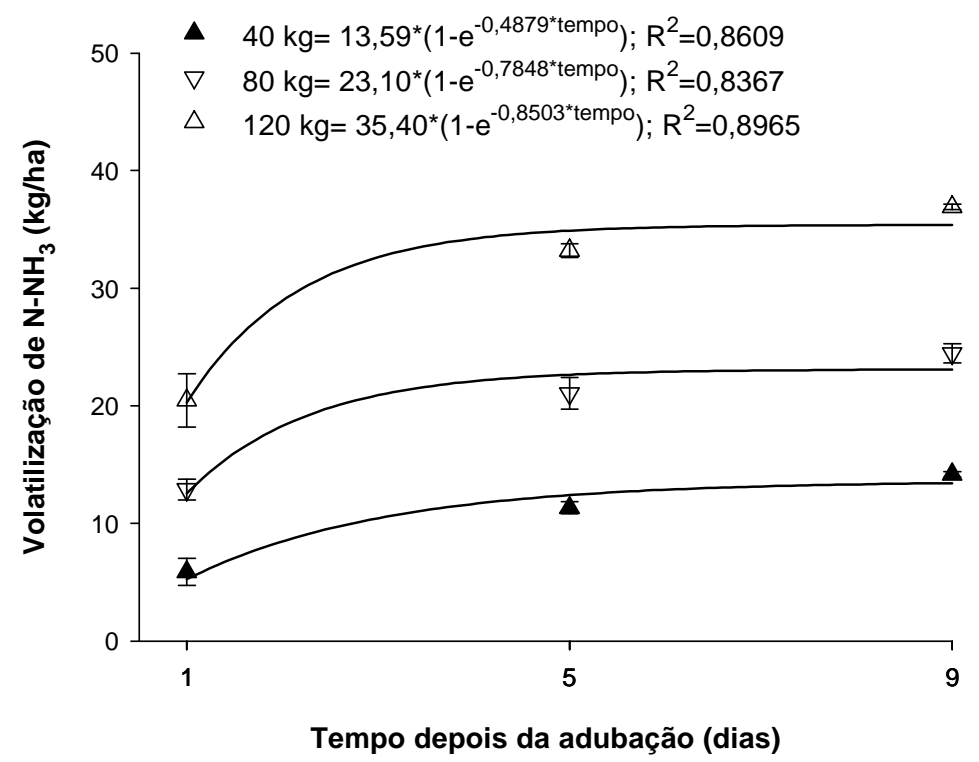

Figura 1 - Perda acumulada de $\mathrm{N}-\mathrm{NH}_{3}(\mathrm{~kg} / \mathrm{ha})$ em pastagem de capim Tanzânia adubada com 40, 80 e $120 \mathrm{~kg} / \mathrm{ha}$ de N-uréia.

Observa-se, ainda, que a perda de $\mathrm{N}-\mathrm{NH}_{3}$ medida no dia seguinte à adubação foi a principal responsável pela volatilização acumulada de $\mathrm{N}^{-\mathrm{NH}_{3}}$ no período, uma vez que nas avaliações efetuadas nos dias 5 e 9 não se observou diferenças na taxa diária de volatilização nas adubações com 40, 80 e 120 kg/ha de N-uréia (Figura 2).

As taxas diárias de volatilização de $\mathrm{N}-\mathrm{NH}_{3}$, para uma dada dose do fertilizante, diminuíram $(\mathrm{P}<0,05)$ de maneira exponencial nos tempos de avaliação. Tomando como referencial a medida de volatilização realizada no dia 1 calcula-se, pelas equações apresentadas na Figura 3, que, no período (do dia 1 ao dia 9), a redução na taxa de volatilização diária de amônia foi de 6, 8 e 10 vezes nas adubações com 40, 80 e 120 kg/ha de N-uréia, respectivamente. Esse comportamento é coerente com o padrão de volatilização acumulada de $\mathrm{N}-\mathrm{NH}_{3}$ apresentado na Figura 1. 


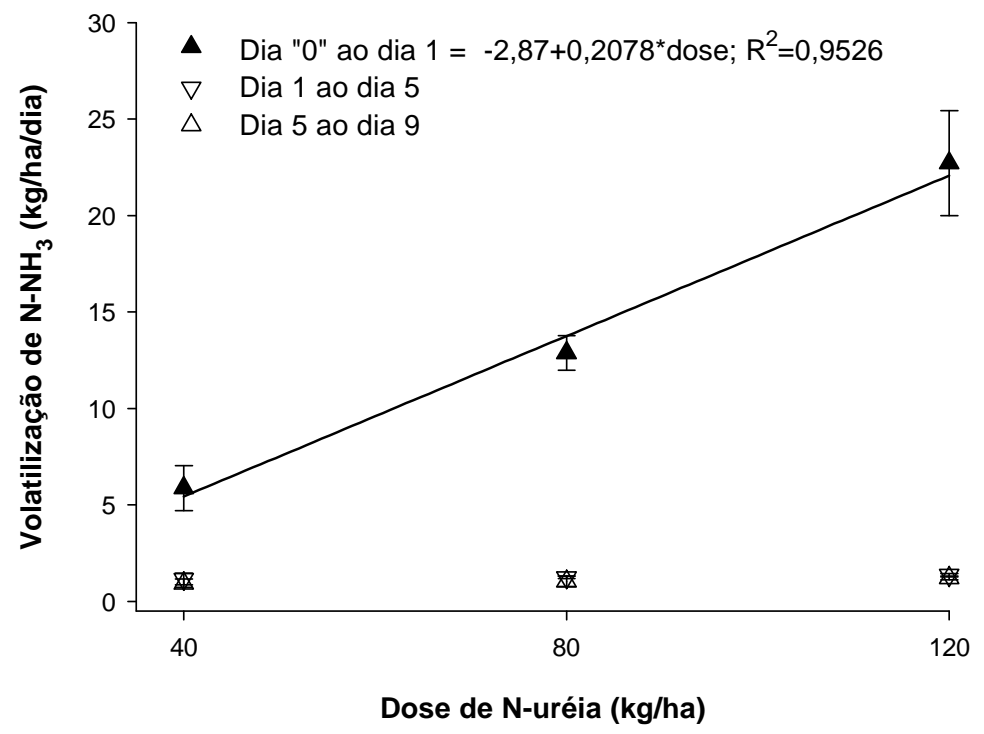

Figura 2 - Taxa diária de volatilização de $\mathrm{N}^{-\mathrm{NH}_{3}}$ ( $\left.\mathrm{kg} / \mathrm{ha} / \mathrm{dia}\right)$ em pastagem de capim Tanzânia adubada com 40, 80 e 120 kg/ha de N-uréia.

Os resultados referentes à volatilização acumulada de $\mathrm{N}-\mathrm{NH}_{3}$ e às taxas diárias de volatilização podem ser explicados pela ação conjunta de fatores de solo e de clima que proporcionaram elevada concentração de $\mathrm{N}-\mathrm{NH}_{3}$ próxima à superfície do solo e alta taxa de perda de água do solo e, dessa maneira, determinaram um elevado potencial de perda de $\mathrm{N}-\mathrm{NH}_{3}$ para fora do sistema solo-planta. Pode-se citar, como fatores de solo, o elevado potencial de hidrólise da uréia em solos vegetados por pastagens, a elevação do pH no local de hidrólise da uréia e os elevados níveis de conteúdo de água no solo (Ernst \& Massey, 1960; Black et al., 1985; Hargrove, 1988). Como fatores de clima, destacam-se a elevada temperatura e a falta de chuva no dia subseqüente à aplicação do fertilizante (Black et al., 1987; Bouwmeester et al., 1985; Hargrove, 1988).

A expressiva redução na taxa diária de volatilização nos primeiros dias depois adubação pode indicar que a amônia moveu-se para camadas mais profundas do solo, onde o processo de volatilização de $\mathrm{N}^{-\mathrm{NH}_{3}}$ é reduzido (Rodrigues \& Kiehl, 1986; 1992; Hargrove, 1988). É interessante notar que a reposição de água dentro dos coletores, no dia 5 depois da adubação (o equivalente a $70 \mathrm{~mm}$ de chuva), não reduziu adicionalmente a taxa de perda diária de $\mathrm{N}-\mathrm{NH}_{3}$ (Figuras 2 e 3) e não aumentou, de maneira expressiva, as perdas acumuladas de $\mathrm{N}-\mathrm{NH}_{3}$ (Figura 1). 


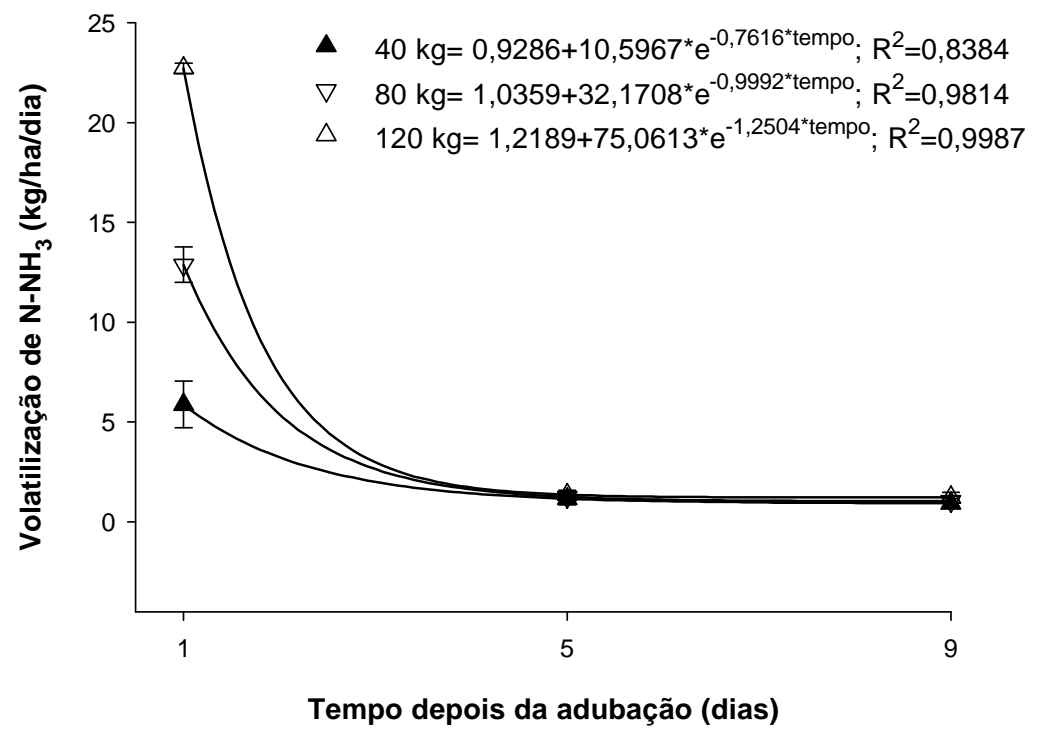

Figura 3 - Perda diária de $\mathrm{N}-\mathrm{NH}_{3}(\mathrm{~kg} / \mathrm{ha} / \mathrm{dia})$ em pastagem de capim Tanzânia adubada com 40, 80 e $120 \mathrm{~kg} / \mathrm{ha}$ de $\mathrm{N}$-uréia.

Entretanto, pode-se argumentar que as chuvas verificadas entre os dias 1 e 5 depois da adubação, em particular nos dias 2 e 3 (Tabela 1), indicam que a não reposição de água, nesse período, determinou superestimativa dos valores de volatilização acumulada e de taxa diária de perda de $\mathrm{N}-\mathrm{NH}_{3}$. O fato de as perdas de amônia se concentrarem nos primeiros dias depois da adubação de certa forma dão suporte a essa afirmação. Com efeito, considerando a área não vegetada da pastagem e as equações da Figura 1, calcula-se que as perdas medidas no dia 1 depois da adubação, para as doses de 40,80 e $120 \mathrm{~kg} /$ ha de $\mathrm{N}$-uréia, responderam por 39, 54 e $57 \%$ das perdas totais de $\mathrm{N}$ $\mathrm{NH}_{3}$ determinadas. No dia 3, as respectivas perdas já contabilizavam 78, 91 e $92 \%$ das perdas totais de $\mathrm{N}-\mathrm{NH}_{3}$.

Ressalta-se que o padrão e a extensão de volatilização de amônia observados nesse estudo estão de acordo com outros experimentos realizados com gramíneas tropicais (Martha Júnior, 1999; Primavesi et al., 2001), indicando que grandes quantidades do $\mathrm{N}$ proveniente da uréia aplicada superficialmente em pastagens podem ser rapidamente perdidas do sistema solo-planta.

A extensão e o padrão das perdas de $\mathrm{N}^{-\mathrm{NH}_{3}}$ proveniente da uréia aplicada superficialmente àpastagem sinalizam que durante o verão (elevadas temperaturas) e na 
ausência de chuvas imediatamente depois da adubação (Tabela 1), as medidas de manejo para controlar as perdas de $\mathrm{N}-\mathrm{NH}_{3}$ só serão efetivas se: 1) praticadas logo depois da aplicação do fertilizante nitrogenado, preferivelmente antes de 1 dia depois da adubação; 2) considerarem a manipulação da uréia (misturas de sais com uréia); ou 3) utilizarem outra fonte de fertilizante nitrogenado que não a uréia.

Embora a incorporação da uréia ao solo reduza sensivelmente as perdas de $\mathrm{N}^{-\mathrm{NH}_{3}}$ (Ernst \& Massey, 1960; Rodigues \& Kiehl, 1986), a restrição quanto à incorporação da uréia em pastagens cespitosas, no sentido de não comprometer a perenidade da pastagem (Corsi \& Nussio, 1993; Corsi et al., 2001b), evidencia a necessidade de outras alternativas de manejo para reduzir as perdas de amônia por volatilização e, conseqüentemente, aumentar a eficiência de uso do N-uréia pelo capim Tanzânia.

Para contornar o problema das perdas de $\mathrm{N}-\mathrm{NH}_{3}$ em pastagens poder-se-ia utilizar sais amoniacais, que são menos propensos a perder o $\mathrm{N}$ na forma de $\mathrm{N}^{-\mathrm{NH}_{3}}$ em comparação com a uréia (Martha Júnior, 1999; Primavesi et al., 2001). Contudo, como a uréia é o fertilizante nitrogenado mais barato no mercado, cabe ao produtor/técnico decidir se vale a pena pagar mais para minimizar os riscos de perda de amônia por volatilização.

Misturas de sais com uréia também poderiam ser utilizadas para reduzir as perdas de $\mathrm{N}^{-\mathrm{NH}_{3}}$ por volatilização, mas as evidências sobre a efetividade dessa prática, no aumento da eficiência de uso do $\mathrm{N}$ da uréia, não são consistentes (Rappaport \& Axley, 1984; Oliveira, 2001; Vitti et al., 2001). Embora a relação N:S dos tratamentos (4:1, 8:1 e 12:1 para os tratamentos adubados com 40, 80 e $120 \mathrm{~kg} / \mathrm{ha}$ de $\mathrm{N}$-uréia, respectivamente) tenha variado nesse experimento, não foi possível separar o efeito de doses crescentes do fertilizante nitrogenado dos potenciais benefícios da redução das perdas de $\mathrm{N}-\mathrm{NH}_{3}$ advindos da menor relação N:S no fertilizante (Lara Cabezas et al., 1992).

O uso de irrigação logo depois da adubação também é uma prática efetiva na redução das perdas de $\mathrm{N}-\mathrm{NH}_{3}$ do sistema solo-planta (Bouwmeester et al., 1985; Black et al., 1987), mas a aplicação de água de irrigação é geralmente feita com base na água disponível no solo e, na maioria das vezes, a decisão do momento de irrigação não considera a aplicação do fertilizante nitrogenado. Embora a irrigação possa ser praticada considerando o manejo do fertilizante nitrogenado, em associação à água disponível no solo, a irrigação em solos que já apresentam níveis de água próximos à capacidade campo pode determinar perdas elevadas de N por desnitrificação (Linn \& Doran, 1984; Granli \& Bockman, 1995). Nessas condições, a irrigação poderia reduzir as perdas de $\mathrm{N}$ por volatilização de amônia, mas, em contrapartida, poderia potencializar as perdas do 
elemento por desnitrificação e, em especial no caso de solos arenosos e rasos, potencializaria, também, as perdas por lixiviação de $\mathrm{N}-\mathrm{NO}_{3}$.

Com relação ao presente experimento, pode-se inferir que apesar de as perdas de $\mathrm{N}-\mathrm{NH}_{3}$ terem sido substancialmente reduzidas a partir do dia seguinte à adubação (Figura 3), a perda de $\mathrm{N}$ por desnitrificação provavelmente manteve-se em patamares altos em razão da manutenção da umidade do solo em níveis elevados (Linn \& Doran, 1984; Granli \& Bockman, 1995), principalmente na superfície, onde constatou-se o encharcamento do solo nos dias subseqüentes à adubação. Essas perdas por desnitirificação seriam mais expressivas nas doses mais elevadas de $\mathrm{N}$, conforme orienta o trabalho de Veldkamp et al. (1998). A baixa recuperação do ${ }^{15} \mathrm{~N}$-uréia no sistema solo-planta, principalmente nas maiores doses de adubação (i.e. < 35\% do $\mathrm{N}$ aplicado nas adubações maiores do que 80 $\mathrm{kg} / \mathrm{ha}$ de $\mathrm{N}$ ), dá suporte a essa idéia (capítulo 6). Nesse estudo, verificou-se ainda que a combinação de elevada umidade do solo, ausência de chuvas durante o primeiro dia depois da adubação e temperatura elevada determinaram baixa eficiência agronômica do $\mathrm{N}$-uréia aplicado em pastagem de capim Tanzânia.

Em razão do elevado risco de perda do $\mathrm{N}$-uréia aplicado, nessas condições, recomenda-se que estudos futuros considerem as seguintes alternativas para controlar a volatilização de $\mathrm{N}-\mathrm{NH}_{3}$ e, conseqüentemente, aumentar a eficiência de uso do $\mathrm{N}$-fertilizante pelo capim Tanzânia: 1) o uso de irrigação imediatamente depois da adubação sem, no entanto, favorecer a desnitrificação; 2) o uso de misturas de sais com uréia para determinar se a manipulação da relação N:S do fertilizante, por exemplo, é realmente uma maneira eficaz de controlar as perdas de $\mathrm{N}-\mathrm{NH}_{3}$ em ecossistemas de pastagens tropicais; e 3) o uso de outras fontes de fertilizante nitrogenado menos propensas às perdas de amônia por volatilização, como os sais amoniacais. A utilização de outros fertilizantes nitrogenados, que não a uréia, parece ser, no curto-prazo, a alternativa mais viável tecnicamente (Martha Júnior, 1999; Primavesi et al., 2001).

Adicionalmente, tem sido demonstrado que parte do $\mathrm{N}$ volatilizado pode ser absorvido pela cobertura vegetal, o que contribuiria para minimizar as perdas de $\mathrm{N}-\mathrm{NH}_{3}$ do sistema solo-planta. Em estudo recente com capim Tanzânia observou-se que 2,5 a 16,0\% do $\mathrm{N}$ volatilizado foi absorvido pelas plantas (capítulo 8). Dessa maneira, estudos futuros também deveriam considerar esse aspecto da dinâmica do N no sistema solo-pastagematmosfera. 


\subsection{Conclusões}

A combinação de elevada umidade do solo, ausência de chuvas durante o primeiro dia depois da adubação e temperatura elevada determinaram elevadas perdas de amônia por volatilização, 44\% do N aplicado na média das adubações com 40, 80 e $120 \mathrm{~kg} / \mathrm{ha}$ de $\mathrm{N}$-uréia. A volatilização acumulada aumentou com o período depois da adubação, apesar das taxas de perda de amônia terem sido decrescentes nesse intervalo, sendo constatado maiores valores de volatilização acumulada $(\mathrm{kg} / \mathrm{ha})$ nas doses mais elevadas de $\mathrm{N}$-uréia. 


\section{ABSORÇÃO FOLIAR DA AMÔNIA VOLATILIZADA DA URÉIA APLICADA AO SOLO POR PASTAGEM DE CAPIM TANZÂNIA}

\section{Resumo}

Avaliou-se o efeito da dose de N-uréia (40, 80 e $120 \mathrm{~kg} / \mathrm{ha}$ de $\mathrm{N})$ e da distância (0, 27 e $35 \mathrm{~cm}$ ) entre dreno (folhas) e fonte (uréia aplicada ao solo) sobre a absorção foliar de amônia por pastagem de capim Tanzânia. Adotou-se um delineamento de blocos completos casualizados, no esquema de parcelas subdivididas, com quatro repetições. Não houve efeito da distância sobre a absorção foliar de amônia ( $P>0,05)$, mas a absorção diminuiu exponencialmente $(\mathrm{P}<0,05)$ com o incremento nas doses de $\mathrm{N}$-uréia ou da taxa de volatilização de amônia. A absorção foliar de amônia variou de 2,5 (120 kg/ha de Nuréia) a 16,4\% (40 kg/ha de N-uréia) do nitrogênio volatilizado.

\section{LEAF ABSORPTION OF AMMONIA VOLATILIZED FROM UREA APPLIED TO SOIL BY TANZANIA GRASS PASTURE}

\section{Summary}

The effect of urea- $\mathrm{N}$ rate $(40,80$ and $120 \mathrm{~kg} / \mathrm{ha}$ of $\mathrm{N})$ and distance $(0,27$ and 35 $\mathrm{cm}$ ) between sink (leaf) and source (urea applied to soil) on leaf absorption of ammonia by Tanzania grass pasture was evaluated. A randomized complete block design, following a split-plot arrangement with four replicates, was adopted. The distance had no effect on leaf absorption of ammonia $(P>0.05)$, but the absorption exponentially decreased $(P<0.05)$ with increasing $\mathrm{N}$-rates or ammonia volatilization rates. The leaf absorption of ammonia varied from 2.5 (120 kg urea-N/ha) to $16.4 \%$ (40 kg urea-N/ha) of the volatilized nitrogen. 


\subsection{Introdução}

Estudos recentes mostraram que até $80 \%$ do $\mathrm{N}$-uréia aplicado superficialmente em pastagens tropicais pode ser perdido do sistema solo-planta, em razão da volatilização de amônia - $\mathrm{NH}_{3}$ (Martha Júnior, 1999; Primavesi et al., 2001). Entretanto, também tem sido demonstrado que parte do $\mathrm{N}^{-\mathrm{NH}_{3}}$ volatilizado do fertilizante ou esterco aplicados em agroecossistemas pode ser absorvido pelas folhas (Sommer et al., 1993; Ping et al., 2000). Diversos fatores irão interferir na absorção foliar de $\mathrm{N}-\mathrm{NH}_{3}$, como o ponto de compensação de amônia na planta, a concentração de $\mathrm{N}-\mathrm{NH}_{3}$ na atmosfera e a área foliar da cultura.

O ponto de compensação de amônia varia com a espécie e com o estádio fisiológico da planta, mas, normalmente, esse valor é semelhante à concentração de $\mathrm{N}-\mathrm{NH}_{3}$ na atmosfera (1 a $6 \mu \mathrm{g} / \mathrm{m}^{3}$; Farquhar et al., 1980). Quando a concentração de $\mathrm{N}-\mathrm{NH}_{3}$ na atmosfera encontra-se abaixo do ponto de compensação, os vegetais irão emitir esse gás para a atmosfera, enquanto que para concentrações de $\mathrm{N}-\mathrm{NH}_{3}$ acima do ponto de compensação, as plantas irão absorver amônia da atmosfera. Imediatamente depois da aplicação superficial de $\mathrm{N}$-uréia em pastagens, a concentração de $\mathrm{N}-\mathrm{NH}_{3}$ na atmosfera pode elevar-se para níveis superiores a $1.000 \mu \mathrm{g} / \mathrm{m}^{3}$ nas proximidades da superfície do solo (Harper et al., 1983). Nessas situações, o potencial de absorção foliar de amônia pode aumentar, especialmente quando o índice de área foliar (IAF) é elevado (Sommer et al., 1993).

Pastagens de Panicum maximum apresentam baixo IAF logo depois do pastejo (Zimmer, 1999; Mello, 2002), característica que pode limitar a absorção do $\mathrm{N}^{-\mathrm{NH}_{3}}$ proveniente do fertilizante aplicado ao pasto. O processo de absorção de $\mathrm{N}^{-\mathrm{NH}_{3}}$ ainda é prejudicado pelo aumento da distância entre o dreno (folhas) e a fonte emissora de $\mathrm{N}-\mathrm{NH}_{3}$, que impõe limites à recaptura de $\mathrm{N}-\mathrm{NH}_{3}$ por via foliar (Ping et al., 2000).

O capim Tanzânia tem sido uma das principais opções para sistemas com elevado uso de insumos, em que a aplicação de fertilizantes nitrogenados é normalmente feita de maneira superficial e a lanço e, de preferência, com uréia. Nesse contexto, estudos sobre a absorção de $\mathrm{N}-\mathrm{NH}_{3}$, nesses ecossistemas, são de interesse. O presente trabalho teve 0 objetivo de estimar, no curto-prazo, o efeito de doses de $\mathrm{N}$-uréia e da distância entre o dreno e a fonte de amônia sobre a absorção foliar de $\mathrm{N}-\mathrm{NH}_{3}$ pelo capim Tanzânia. 


\subsection{Material e Métodos}

O estudo foi realizado em pastagem estabelecida de $P$. maximum cv. Tanzânia, no Campus da Escola Superior de Agricultura "Luiz de Queiroz", Universidade de São Paulo, Piracicaba-SP (altitude 580 m; 2241'30" S; 47³8'00" W).

Os protocolos experimentais basearam-se na proposta descrita por Ping et al. (2000). Entretanto, o método foi modificado para ser aplicado em pastagem de capim Tanzânia, em que as plantas encontram-se distribuídas de maneira desuniforme na área. A premissa básica foi assegurar que o $\mathrm{N}$ marcado na planta fosse proveniente da absorção pelas folhas e não da absorção radicular. Tal condição foi atendida pelo uso de bandejas (18,5 cm de diâmetro $\times 7 \mathrm{~cm}$ de altura), que evitaram o contato do fertilizante ${ }^{15} \mathrm{~N}$ aplicado no solo contido nessas bandejas com as raízes das plantas.

Cada parcela, representada por três touceiras, uma adjacente e outras duas em diferentes distâncias da fonte de amônia, foi locada aleatoriamente em um piquete de $1.333 \mathrm{~m}^{2}$. Os valores médios para as distâncias da área basal dessas duas touceiras mais distantes até o limite da bandeja (fonte de amônia) foram de $54( \pm 4,3)$ e $71( \pm 5,1) \mathrm{cm}$, respectivamente. Os valores correspondentes para a área de sombreamento dessas plantas foram de $27( \pm 3,2)$ e $35( \pm 4,5) \mathrm{cm}$. Adotou-se um delineamento inteiramente casualizado, com quatro repetições, representado por três tratamentos nas parcelas (adubações equivalentes a 40, 80 e $120 \mathrm{~kg} / \mathrm{ha}$ de $\mathrm{N}$-uréia) e três tratamentos nas subparcelas (distâncias médias entre a área de sombreamento das plantas - 0, 27 e $35 \mathrm{~cm}$ - até a fonte de $\mathrm{N}-\mathrm{NH}_{3}$ ). Utilizou-se uma bandeja por parcela.

O experimento começou no dia seguinte à saída dos animais do piquete (26/03/2002), no início da manhã (08:00 hs.), e continuou até às 14:00 hs. do dia 27/03/2002. As características climáticas médias durante 0 experimento foram: temperaturas mínima, média e máxima de $18,2^{\circ} ; 25,3^{\circ}$ e $32,4^{\circ} \mathrm{C}$, respectivamente; umidade relativa do ar de $82 \%$; evaporação de $5,0 \mathrm{~mm} /$ dia e velocidade do vento de $5,7 \mathrm{~km} / \mathrm{h}$. No dia 26 não se registrou chuvas. No dia 27 , depois do término do experimento, ocorreu uma leve chuva $(6,2 \mathrm{~mm})$ no final da tarde.

Utilizou-se amostras de um solo Podzólico Vermelho-escuro (Argissolo vermelho) de textura argilosa, proveniente da camada de 0 a $20 \mathrm{~cm}$, com as seguintes características químicas: matéria orgânica - $25 \mathrm{~g} / \mathrm{kg} ; \mathrm{pH}\left(\mathrm{CaCl}_{2}\right)-5,1 ; \mathrm{P}$ (resina) - 19,1 mg/dm ${ }^{3} ; \mathrm{K}, \mathrm{Ca}$,

$\mathrm{Mg} \mathrm{e} \mathrm{H}+\mathrm{Al}-4,2 ; 41 ; 21$ e $35 \mathrm{mmolc} / \mathrm{dm}^{3}$, respectivamente. Cerca de $430 \mathrm{~g}$ do solo seco ao ar foi colocado em cada bandeja e a umidade desse solo foi corrigida para a capacidade de 
campo, visando não limitar a volatilização de $\mathrm{N}-\mathrm{NH}_{3}$. As doses de $\mathrm{N}(40,80$ e $120 \mathrm{~kg} / \mathrm{ha}$ de $\mathrm{N}$-uréia) foram estabelecidas por meio da aplicação de uma solução de ${ }^{15} \mathrm{~N}$-uréia (3-mL por bandeja) enriquecida com $5 \%$ de átomos em excesso.

No final da tarde do dia 26 avaliou-se a altura média do nível do solo àcurvatura da folha mais alta da planta por meio de regra graduada e o IAF médio das plantas, com analisador de dossel LI-COR modelo LAI 2000 (Welles \& Norman, 1991). Por volta das 18:30 hs., as bandejas foram acondicionadas em sacos plásticos até a manhã do dia seguinte ( \pm 07:00 hs., 27/03), para evitar que uma provável ocorrência de chuvas durante a noite/início da manhã provocasse a perda de solo e/ou do $\mathrm{N}$ marcado da bandeja. Ao término do experimento, o solo de cada bandeja foi acidificado com $20 \mathrm{~mL}$ de ácido sulfúrico $2 \mathrm{~N}$. Depois da acidificação, os solos foram colocados em estufa com ventilação forçada de ar $\left(60^{\circ} \mathrm{C}\right)$ por 48 horas. A acidificação e rápida secagem do solo visaram paralisar, rapidamente, o processo de volatilização de $\mathrm{N}_{-} \mathrm{NH}_{3}$ nos solos das bandejas.

As touceiras de cada parcela foram cortadas ao nível do solo e a massa seca dessas amostras foi determinada em estufa com ventilação forçada de $\operatorname{ar}\left(60^{\circ} \mathrm{C}, 72 \mathrm{~h}\right)$. As amostras de solo e de planta foram moídas $(1 \mathrm{~mm})$ e o $\mathrm{N}$ total e a abundância isotópica de ${ }^{15} \mathrm{~N}$ dessas amostras foram determinados em espectrômetro de massa ANCA SL-20 20 (Europa Scientific; Barrie \& Prosser, 1996). O nitrogênio proveniente do fertilizante marcado (Npfm) foi calculado pela eq. (1).

$\mathrm{Npfm}=(\mathrm{a} \div \mathrm{b}) \times 100$

em que "a" e "b" representam o excesso de ${ }^{15} \mathrm{~N}$ (\% de átomos de ${ }^{15} \mathrm{~N}$ em excesso) na planta ou solo e no fertilizante, respectivamente. Os valores-base de ${ }^{15} \mathrm{~N}$ na planta e no solo foram de $0,3663 \%$ e $0,3685 \%$ de átomos em excesso, respectivamente.

Calculou-se a recuperação percentual de ${ }^{15} \mathrm{~N}\left(\mathrm{R}^{15} \mathrm{~N}\right)$ na planta, expressa em relação ao $\mathrm{N}$ aplicado e ao $\mathrm{N}^{-\mathrm{NH}_{3}}$ volatilizado, pela eq. (2). A taxa de volatilização foi calculada pela quantidade aplicada de ${ }^{15} \mathrm{~N}$ subtraída do ${ }^{15} \mathrm{~N}$ recuperado no solo.

$\mathrm{R}^{15} \mathrm{~N}=\{$ (Npfm $\times$ quantidade de $\mathrm{N}$ no componente $) \div$ quantidade de $\mathrm{N}$-fertilizante adubada ou volatilizada\} x 100 
Os dados foram testados quanto à normalidade dos erros e homogeneidade de variâncias e as análises estatísticas foram feitas com os recursos do pacote estatístico SAS System (SAS, 1989).

\subsection{Resultados e discussão}

$\mathrm{Na}$ Tabela 1, observa-se que as características das plantas, nos diferentes tratamentos, foram semelhantes. Os valores de IAF, que refletem o potencial das plantas em absorver o $\mathrm{N}^{-\mathrm{NH}_{3}}$ da atmosfera, encontram-se dentro da faixa $(0,4$ a 2,6) relatada na literatura para P. maximum no período pós-desfolha (Zimmer, 1999; Mello, 2002). Os valores relativamente baixos de IAF podem ser explicados pela estrutura aberta da vegetação de pastagens de $P$. maximum, com alta proporção de hastes na porção inferior do dossel e com reduzida cobertura da superfície da pastagem pela área basal das plantas (Costa et al., 1992; Penati, 2002).

Tabela 1. Características da pastagem de capim Tanzânia durante o experimento.

\begin{tabular}{ccccccc}
\hline Tratamento $^{1}$ & \multicolumn{2}{l}{ Massa de forragem $^{2}$} & \multicolumn{2}{c}{ Altura $^{3}$} & \multicolumn{2}{c}{ IAF } \\
\hline 40 & 0,57 & $(0,07)^{4}$ & 46,8 & $(1,11)$ & 1,10 & $(0,09)$ \\
80 & 0,46 & $(0,03)$ & 49,5 & $(3,20)$ & 1,03 & $(0,15)$ \\
120 & 0,40 & $(0,07)$ & 45,5 & $(1,44)$ & 1,03 & $(0,07)$ \\
\hline
\end{tabular}

kg/ha de N-uréia; ${ }^{2} \mathrm{~kg} /$ touceira de matéria seca; ${ }^{3} \mathrm{~cm} . ;{ }^{4}$ Os valores entre parênteses referem-se ao erro padrão da média.

O aumento na dose de N-uréia (40,80 e $120 \mathrm{~kg} / \mathrm{ha})$ determinou incrementos significativos ( $\mathrm{P}<0,0001)$, eq. (3), na quantidade de $\mathrm{N}-\mathrm{NH}_{3}$ perdida por volatilização (17 \pm 4,$4 ; 71 \pm 2,8$ e $86 \pm 2,4 \mathrm{~kg} / \mathrm{ha}$ de $\mathrm{N}-\mathrm{NH}_{3}$, respectivamente). As taxas de perda de $\mathrm{N}-\mathrm{NH}_{3}$ foram superiores às relatadas em outros experimentos com pastagens tropicais (Martha Júnior, 1999; Primavesi et al., 2001; capítulo 7). A alta temperatura máxima média $\left(32,4^{\circ} \mathrm{C}\right)$ ajuda a explicar, pelo menos em parte, essas perdas elevadas.

Taxa de perda $\left(\mathrm{kg} / \mathrm{ha}\right.$ de $\left.\mathrm{N}-\mathrm{NH}_{3}\right)=91,37-277,24$ * $\mathrm{e}^{\left(-0,0328^{*} \mathrm{x}\right)}$; $R^{2}=0,9695^{\star \star *}$

em que " $x$ " corresponde à dose de N-uréia. 
Constatou-se, também, que o aumento na dose do fertilizante promoveu maiores perdas expressas como porcentagem do $\mathrm{N}$ aplicado, apesar de a variação da taxa de volatilização ter sido reduzida em 2,6 vezes na amplitude de doses de $\mathrm{N}$-uréia testadas, eq. (3). Contudo, uma vez que a volatilização de $\mathrm{NH}_{3}$ pode ser linear ou exponencial, as perdas relativas (\% do $\mathrm{N}$ aplicado) podem diminuir, permanecerem constantes ou aumentarem com níveis crescentes de aplicação do fertilizante nitrogenado (Hargrove, 1988).

Conforme se depreende do trabalho de Sommer et al. (1993), a estrutura aberta da pastagem de capim Tanzânia não favorece a absorção foliar de $\mathrm{N}^{-\mathrm{NH}_{3}}$, em razão de facilitar a perda do gás para a atmosfera e de não permitir a redução da velocidade do vento no interior da cobertura vegetal. Conseqüentemente, a transferência de $\mathrm{N}-\mathrm{NH}_{3}$ do solo/fertilizante para a atmosfera permanece elevada, diminuindo as chances do $\mathrm{N}-\mathrm{NH}_{3}$ proveniente do fertilizante ser absorvido pelas folhas. Contudo, mesmo sob essas condições desfavoráveis, observou-se efeitos significativos da dose de $N$-uréia $(P<0,0001)$, eq. (4), e da taxa de $\mathrm{N}-\mathrm{NH}_{3}$ volatilizada $(\mathrm{P}<0,0001)$, eq. (5), sobre a absorção foliar desse gás (Tabela 2).

Absorção de $\mathrm{N}-\mathrm{NH}_{3}(\%$ do $\mathrm{N}$ aplicado $)=0,4028+5,52$ * $\mathrm{e}^{\left(-0,0267^{*} \mathrm{x}\right)}$; $\mathrm{R}^{2}=0,9354^{\star \star \star}$

em que "x" corresponde à dose de N-uréia (kg/ha).

Absorção de $\mathrm{N}-\mathrm{NH}_{3}(\%$ do $\mathrm{N}$ volatilizado $)=-0,5907+8,93$ * $\mathrm{e}^{\left(-0,0228^{*} \mathrm{x}\right)}$; $\mathrm{R}^{2}=0,7050^{* * *}$

em que " $\mathrm{x"}$ corresponde à taxa volatilizada de $\mathrm{N}-\mathrm{NH}_{3}(\mathrm{~kg} / \mathrm{ha})$.

Não se observou efeito $(P>0,05)$ da interação entre a dose de $N$-uréia (ou da taxa de $\mathrm{N}$ volatilizado) e a distância do dreno em relação à fonte de $\mathrm{N}-\mathrm{NH}_{3}$. A distância entre a fonte emissora de $\mathrm{N}-\mathrm{NH}_{3}$ e o dreno também não determinou efeito sobre a absorção foliar de amônia $(\mathrm{P}>0,05)$, apesar de a maior parte do $\mathrm{N}$ marcado proveniente do $\mathrm{N}-\mathrm{NH}_{3}$ volatilizado (40 a 50\%) ter sido observada nas plantas mais próximas à fonte de $\mathrm{N}-\mathrm{NH}_{3}$ (Tabela 2). Ping et al. (2000) mostraram diminuição da absorção foliar de amônia com o aumento na distância da fonte de $\mathrm{N}-\mathrm{NH}_{3}$ ("zero" a $2 \mathrm{~m}$ ), sendo que $90 \%$ da amônia proveniente da uréia foi absorvida em até $60 \mathrm{~cm}$ da fonte de $\mathrm{N}-\mathrm{NH}_{3}$. Assim, é possível que 
a amplitude de distâncias testadas (área de sombreamento distante até $35 \mathrm{~cm}$ da fonte de amônia) não tenha sido suficiente para que o efeito da distância fosse verificado.

Tabela 2. Absorção foliar de $\mathrm{N}-\mathrm{NH}_{3}$ pelo capim Tanzânia em razão da dose de N-uréia e da taxa de volatilização de amônia.

\begin{tabular}{|c|c|c|c|c|c|c|c|c|c|c|}
\hline \multirow{2}{*}{$\begin{array}{l}\text { Dose } \\
\text { de } N^{1}\end{array}$} & \multicolumn{6}{|c|}{ Distância da fonte de $\mathrm{N}-\mathrm{NH}_{3}(\mathrm{~cm})^{2}$} & \multicolumn{4}{|c|}{ Absorção total $\left.\right|^{3}$} \\
\hline & \multicolumn{2}{|c|}{0} & \multicolumn{2}{|c|}{27} & \multicolumn{2}{|c|}{35} & \multicolumn{2}{|c|}{$\%$} & \multicolumn{2}{|c|}{$\mathrm{kg}$} \\
\hline & \multicolumn{10}{|c|}{$\%$ do $\mathrm{N}$ aplicado } \\
\hline 40 & 2,69 & $(0,42)^{4}$ & 1,85 & $(0,55)$ & 2,36 & $(0,85)$ & 6,90 & $(0,34)$ & 2,76 & $(0,63)$ \\
\hline 80 & 1,25 & $(0,35)$ & 0,60 & $(0,31)$ & 1,09 & $(0,22)$ & 2,94 & $(0,18)$ & 2,35 & $(0,48)$ \\
\hline \multirow[t]{2}{*}{120} & 0,92 & $(0,33)$ & 0,43 & $(0,22)$ & 0,53 & $(0,24)$ & 1,88 & $(0,15)$ & 2,25 & $(0,95)$ \\
\hline & \multicolumn{10}{|c|}{$\%$ do $\mathrm{N}$ volatilizado } \\
\hline 17 & 6,40 & $(1,01)$ & 4,39 & $(1,31)$ & 5,62 & $(2,02)$ & 16,41 & $(0,81)$ & 2,79 & $(0,63)$ \\
\hline 71 & 1,40 & $(0,39)$ & 0,67 & $(0,34)$ & 1,22 & $(0,25)$ & 3,30 & $(0,20)$ & 2,34 & $(0,48)$ \\
\hline 86 & 1,21 & $(0,43)$ & 0,57 & $(0,29)$ & 0,69 & $(0,32)$ & 2,47 & $(0,20)$ & 2,12 & $(0,89)$ \\
\hline
\end{tabular}

${ }^{1}$ Para \% do $\mathrm{N}$ aplicado, as doses de $\mathrm{N}$ correspondem a 40, 80 e $120 \mathrm{~kg} / \mathrm{ha}$ de $\mathrm{N}$-uréia. Para \% do N volatilizado, os respectivos valores são de 17, 71 e $86 \mathrm{~kg} / \mathrm{ha} .{ }^{2}$ Distância da área de sombreamento das plantas até o limite da fonte emissora de $\mathrm{N}-\mathrm{NH}_{3} .{ }^{3}$ Considera a absorção de $\mathrm{N}-\mathrm{NH}_{3}$ em todas as três distâncias. ${ }^{4}$ Os valores entre parênteses representam o erro padrão da média.

Os valores de absorção de $\mathrm{N}-\mathrm{NH}_{3}$, de 2,5 a $16,4 \%$ do $\mathrm{N}$ volatilizado (Tabela 2), encontram-se dentro da faixa relatada na literatura, de 2 a $15 \%$ do $\mathrm{N}$ volatilizado (Sommer et al., 1993; Ping et al., 2000). A quantidade de $N$ absorvido $(\mathrm{kg} / \mathrm{ha})$ não diferiu $(P>0,05)$ entre as doses de $\mathrm{N}$-uréia ou entre as taxas de $\mathrm{N}_{-} \mathrm{NH}_{3}$ volatilizadas e, em média, $2,5 \mathrm{~kg}$ de $\mathrm{N}$ foram absorvidos (Tabela 2). Entretanto, como as avaliações não consideraram touceiras distribuídas em uma área de $360^{\circ}$, não é possível calcular a quantidade de $\mathrm{N}$ absorvido por unidade de área. Por esse mesmo motivo, não se pode determinar se, na condição estudada, houveram limites à absorção foliar de $\mathrm{N}-\mathrm{NH}_{3}$, em razão, por exemplo, da combinação de baixo IAF residual no período imediatamente depois do pastejo e da estrutura aberta da vegetação.

Por um lado, um maior período de avaliação poderia determinar maior absorção foliar de $\mathrm{N}-\mathrm{NH}_{3}$, em razão do aumento do IAF com o avançar do período de rebrota (Mello, 2002). Por outro lado, apesar da curta duração do experimento (i.e. 30 horas), os resultados gerados nesse estudo representaram as transformações de maior magnitude relacionadas à volatilização de $\mathrm{N}-\mathrm{NH}_{3}$, uma vez que depois do primeiro dia da adubação 
superficial com uréia em pastagens, as taxas de volatilização de $\mathrm{NH}_{3}$ são drasticamente reduzidas (Martha Júnior, 1999; Primavesi et al., 2001; capítulo 7), tendência também observada para as concentrações de $\mathrm{N}^{-\mathrm{NH}_{3}}$ na atmosfera (Harper et al., 1983). Esses fatos diminuem o potencial de absorção desse gás por via foliar. Ademais, para resíduos póspastejo de 1.000 a $4.000 \mathrm{~kg} /$ ha de matéria seca verde, em pastagem de capim Tanzânia, a taxa de incremento diário no IAF (1 a 33 dias de rebrota) foi de 0,1 unidades (Mello, 2002), o que deixa dúvidas quanto ao aumento potencial da capacidade da planta em absorver a amônia da atmosfera nos primeiros dias de rebrota da pastagens.

Por fim, é interessante ressaltar que mais estudos avaliando o efeito da massa de forragem residual, de taxas de volatilização de $\mathrm{N}^{-\mathrm{NH}_{3}}$ inferiores a $17 \mathrm{~kg} / \mathrm{ha}$ e da distância entre o dreno (folhas) e a fonte emissora de amônia são necessários para um mais completo entendimento dessa via de reciclagem do $\mathrm{N}$ em pastagens de capim Tanzânia.

\subsection{Conclusões}

A dose de N-uréia e a taxa de volatilização de amônia tiveram efeito sobre a absorção foliar de $\mathrm{N}-\mathrm{NH}_{3}$ expressa em termos percentuais (\% do $\mathrm{N}$ aplicado ou \% do $\mathrm{N}$ volatilizado). Contudo, quanto maior a adubação ou a taxa de volatilização, menor foi o percentual de $\mathrm{N}^{-\mathrm{NH}_{3}}$ absorvido pela planta forrageira. Não se constatou efeito da distância entre o dreno e a fonte de amônia sobre a absorção foliar desse gás para uma área de sombreamento distante até $35 \mathrm{~cm}$ do local de emissão de amônia. 


\section{DISCRIMINAÇÃO DO ${ }^{13} \mathrm{C}$ ASSOCIADA À NUTRIÇÃO NITROGENADA E À PRODUTIVIDADE DE PASTAGEM IRRIGADA DE CAPIM TANZÂNIA}

\section{Resumo}

Realizou-se um experimento, no delineamento de blocos completos casualizados com quatro repetições, para avaliar a discriminação do ${ }^{13} \mathrm{C}$ em pastagem irrigada de Panicum maximum cv. Tanzânia fertilizada com níveis crescentes de sulfato de amônio (0, $30,60,90$ e $120 \mathrm{~kg} / \mathrm{ha}$ de $\mathrm{N}$ ) durante o verão. A massa de forragem, a quantidade de nitrogênio e o conteúdo de nitrogênio total na forragem responderam quadraticamente ao aumento na dose do fertilizante. Observou-se tendência de redução na discriminação do ${ }^{13} \mathrm{C}$ com o aumento na dose aplicada de nitrogênio $(\mathrm{P}<0,0724)$ e correlação negativa $(P<0,05)$ entre a discriminação de ${ }^{13} \mathrm{C}$ com a quantidade de nitrogênio $(r=-0,60)$ e com o conteúdo de nitrogênio total na forragem $(r=-0,61)$.

\section{${ }^{13} \mathrm{C}$ DISCRIMINATION ASSOCIATED WITH NITROGENOUS NUTRITION AND WITH THE PRODUCTIVITY OF IRRIGATED TANZANIA GRASS PASTURE}

\section{Summary}

A randomized complete block design experiment with four replicates was performed to evaluate the ${ }^{13} \mathrm{C}$ discrimination by irrigated Panicum maximum cv. Tanzania pasture fertilized with increasing amounts of ammonium sulfate $(0,30,60,90$ and $120 \mathrm{~kg} / \mathrm{ha}$ of $\mathrm{N})$ during the summer. Herbage mass, nitrogen yield and total nitrogen content quadratically responded to increasing fertilizer rates. It was observed a trend for decreasing ${ }^{13} \mathrm{C}$ discrimination $(\mathrm{P}<0,0724)$ with increasing nitrogen application rates and negative correlation $(P<0,05)$ between ${ }^{13} \mathrm{C}$ discrimination with nitrogen yield $(r=-0.60)$ and total nitrogen content $(r=-0.61)$. 


\subsection{Introdução}

O nitrogênio $(\mathrm{N})$ desempenha função importante em pastagens de gramíneas tropicais. Quando o suprimento de N no solo é inadequado para atender as exigências da planta forrageira, a produtividade de forragem é reduzida e se o déficit na disponibilidade de $\mathrm{N}$ for prolongada por um longo período de tempo, a pastagem eventualmente entrará em processo de degradação (Robbins et al., 1989; Myers \& Robbins, 1991).

A redução no perfilhamento e na taxa de elongação foliar estão relacionados com o baixo suprimento de $\mathrm{N}$ no sistema e ajudam explicar reveses na produção de forragem em ambientes com níveis subótimos de $N$ (Corsi, 1984). A menor produção vegetal sob condições de deficiência de $\mathrm{N}$ também é explicada pela redução da eficiência do sistema que fixa o $\mathrm{CO}_{2}$ em plantas $\mathrm{C} 4$ (Meinzer \& Zhu, 1998), em adição à diminuição das taxas de fotossíntese (Hopkins, 1995). Entretanto, a necessidade de equipamentos específicos para a realização de medições de fotossíntese, no campo, limita essas avaliações a um número reduzido de experimentos.

Uma alternativa para avaliar, indiretamente, a relação entre a eficiência do processo fotossintético e o "status" de N no sistema, sem a necessidade de uso de equipamentos específicos no campo, seria por meio da avaliação da discriminação do ${ }^{13} \mathrm{C}$. O método baseia-se no fato de que em condições de estresse (baixa disponibilidade de água, luz ou nitrogênio), há aumento da discriminação do isótopo pesado de carbono $\left({ }^{13} \mathrm{C}\right.$; Boutton, 1996; Meinzer \& Zhu, 1998), em razão de pequenas diferenças em propriedades físicas e bioquímicas na fotossíntese, resultantes da diferença na massa dos isótopos ${ }^{13} \mathrm{C}$ e ${ }^{12} \mathrm{C}$ (O'Leary, 1988). Em plantas C4, os processos em que o fracionamento é mais significativo são a difusão estomatal e a carboxilação da fosfoenolpiruvato, sendo a difusão considerada etapa mais limitante ao processo fotossintético e ao fracionamento do ${ }^{13} \mathrm{C}$ do que a carboxilação (O'Leary, 1988).

Embora o entendimento da relação entre o processo fotossintético e o "status" de N no sistema seja útil para explicar a resposta da forrageira ao suprimento de $\mathrm{N}$, estudos delineados com esse fim são pouco comuns no Brasil. O presente trabalho avaliou a discriminação do ${ }^{13} \mathrm{C}$ em pastagem de capim Tanzânia irrigada e adubada com doses crescentes de fertilizante nitrogenado durante um ciclo de pastejo de verão. 


\subsection{Material e Métodos}

O experimento foi realizado em área experimental da Escola Superior de Agricultura "Luiz de Queiroz", Universidade de São Paulo, Piracicaba-SP (altitude 580 m; 2241'30" S; 473'00" W). Uma pastagem irrigada de Panicum maximum cv. Tanzânia foi adubada com sulfato de amônio $(0,30,60,90$ e $120 \mathrm{~kg} / \mathrm{ha}$ de $\mathrm{N})$ durante o verão, no ciclo de pastejo compreendido pelo período de 12 de janeiro a 17 de fevereiro de 2000 . As características climáticas durante o período experimental constam da Figura 1.

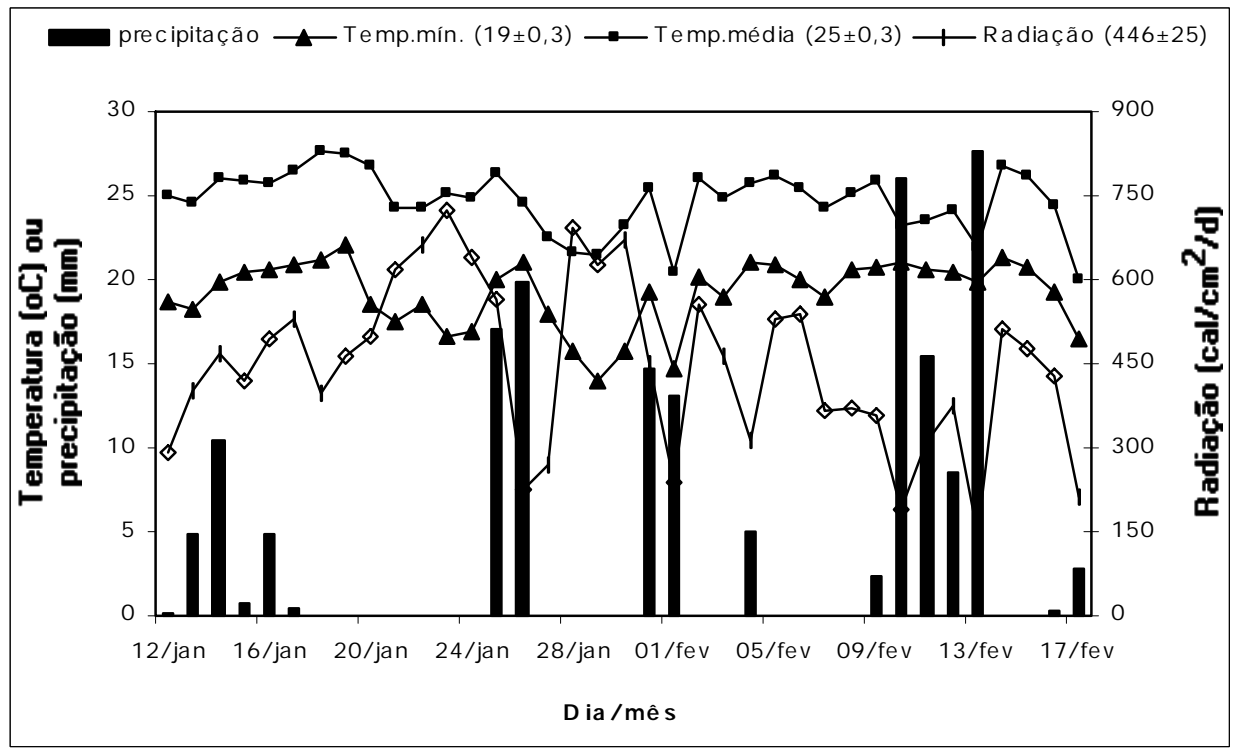

Figura 1 - Características climáticas durante o período experimental. Os valores entre parênteses indicam as médias \pm 0 erro padrão. $O$ total de chuvas registradas no período foi de $174 \mathrm{~mm}$.

O solo, um Podzólico Vermelho-escuro (Argissolo vermelho) de textura argilosa, apresentava $33 \%$ de areia, $23 \%$ de silte e $44 \%$ de argila e as características químicas da camada superficial do solo $(0-20 \mathrm{~cm})$ podem ser descritas por: matéria orgânica -24 $\mathrm{g} / \mathrm{dm}^{3} ; \mathrm{P}$ (resina) - $17 \mathrm{mg} / \mathrm{dm}^{3} ; \mathrm{K}-3,9 \mathrm{mmol} / \mathrm{dm}^{3} ; \mathrm{Ca}-44 \mathrm{mmol} / \mathrm{dm}^{3} ; \mathrm{Mg}$ - 16 $\mathrm{mmol}_{\mathrm{d}} / \mathrm{dm}^{3} ; \mathrm{Al}-1 \mathrm{mmol}_{\mathrm{d}} / \mathrm{dm}^{3} ; \mathrm{e} \mathrm{H}+\mathrm{Al}-38 \mathrm{mmol}_{d} / \mathrm{dm}^{3}$. A correção e adubação do solo foram efetuadas com base na análise de solo e de acordo com a recomendação de Corsi \& Nussio (1993), para elevar a saturação por bases para $70 \%$ e o teor de fósforo e potássio no solo para $20 \mathrm{mg} / \mathrm{dm}^{3}$ e 3 a $5 \%$ da CTC, respectivamente. 
A pastagem foi irrigada por pivô central para atingir a capacidade de campo quando tensiômetros instalados a $20 \mathrm{~cm}$ de profundidade indicaram potencial de água no solo de 0,03 a -0,04 MPa (Lourenço \& Coelho, 2000).

Os tratamentos seguiram um delineamento de blocos completos casualizados com quatro repetições. A massa de forragem $(\mathrm{kg} / \mathrm{ha}$ de matéria seca - MS), a quantidade de $\mathrm{N}$ ( $\mathrm{kg} / \mathrm{ha}$ de $\mathrm{N}$ ) e o teor de $\mathrm{N}$ total na forragem ( $\mathrm{g} / \mathrm{kg} \mathrm{MS}$ ) foram determinados a partir de amostras do estrato superior da pastagem (corte a $30 \mathrm{~cm}$ do solo). A massa de forragem foi determinada por amostra composta representada pelo corte da forragem compreendida em duas áreas de 0,5 x 0,5 m dentro de cada parcela $(3,5 \times 2,5 \mathrm{~m})$. Depois da determinação da massa seca da forragem em estufa com ventilação forçada de $\operatorname{ar}\left(60^{\circ} \mathrm{C}\right.$, $72 \mathrm{~h}$ ), as amostras foram moídas $(1 \mathrm{~mm})$ e o conteúdo de $\mathrm{N}$ total foi determinado pelo método padrão de Kjeldahl. A quantidade de $\mathrm{N}$ foi calculado pelo produto entre a massa de forragem e o teor de $\mathrm{N}$ total na amostra.

A determinação da composição isotópica de ${ }^{13} \mathrm{C}$ das amostras $\left(\delta^{13} \mathrm{C}, \%\right.$ ) foi feita em espectrômetro de massa (ANCA, Europa Scientific, modelo SL 20-20; Barrie \& Prosser, 1996). A composição isotópica de carbono foi expressa como o $\delta^{13} \mathrm{C}$ (\%) em relação ao padrão PDB (Boutton, 1996), com precisão de $\pm 0,02 \%$. Os valores resultantes de $\delta^{13} C_{P D B}$ da amostra foram usados para calcular a discriminação isotópica $\left(\Delta^{13} \mathrm{C}\right.$, \%) de acordo com a eq. (1), simplificada da equação apresentada por Farquhar (1983).

$\Delta^{13} \mathrm{C}=\delta^{13} \mathrm{C}_{\mathrm{PDB}} \mathrm{CO}_{2}$ atm. $-\delta^{13} \mathrm{C}_{\mathrm{PDB}}$ amostra

em que:

$\Delta^{13} \mathrm{C}$ - discriminação do ${ }^{13} \mathrm{C}, \%$;

$\delta^{13} \mathrm{C}_{\mathrm{PDB}} \mathrm{CO}_{2}$ atm. - composição isotópica do $\mathrm{CO}_{2}$ da atmosfera expressa em relação ao padrão (PDB); na ausência de atividades industriais esse valor é relativamente constante e aproximadamente igual a $-8 \%$ (Boutton, 1996);

$\delta^{13} \mathrm{C}_{\mathrm{PDB}}$ amostra - composição isotópica do material amostrado em relação ao padrão.

Os dados foram testados quanto à homogeneidade de variância e normalidade dos erros. A análise de variância e os demais procedimentos estatísticos foram realizados com os recursos do programa SAS System (SAS, 1989). 


\subsection{Resultados e Discussão}

A massa de forragem, eq. (2), e a quantidade de $\mathrm{N}$ na forragem, eq. (3), responderam quadraticamente ao aumento nas doses do fertilizante, apresentando respostas máximas (ponto de inflexão) em 87 e $84 \mathrm{~kg} / \mathrm{ha}$ de $\mathrm{N}$, respectivamente. Essas respostas expressivas à adubação nitrogenada estão de acordo com outros trabalhos realizados com pastagens de P. maximum (Vicente-Chandler et al., 1974; Crespo, 1986). Chama-se àatenção para um possível efeito residual de adubações nitrogenadas prévias e/ou de elevadas taxas de mineralização da matéria orgânica no solo, que determinaram valores de massa de forragem e de quantidade de $\mathrm{N}$ nas parcelas controle relativamente elevados.

Massa seca de forragem $(\mathrm{kg} / \mathrm{ha})=3.434+76,9^{*}$ dose de $\mathrm{N}-0,4436^{*}(\text { dose de } N)^{2}$;

$\mathrm{R}^{2}=0,8562^{* *}$

Quantidade de $N(\mathrm{~kg} / \mathrm{ha})=53,8+1,8^{*}$ dose de $N-0,0107^{\star}(\text { dose de } N)^{2}$;

$\mathrm{R}^{2}=0,8804^{* *}$

O teor de $\mathrm{N}$ total também respondeu quadraticamente aos incrementos na dose do fertilizante, eq. (4), atingindo seu valor máximo na dose de $91 \mathrm{~kg} \mathrm{~N} / \mathrm{ha}$. Incrementos no conteúdo de $\mathrm{N}$ total na forragem, em resposta ao aumento na dose de $\mathrm{N}$, foram relatados em outros experimentos com P. maximum (Vicente-Chandler et al., 1974; Crespo, 1986).

Conteúdo de $\mathrm{N}$ total $(\mathrm{g} / \mathrm{kg})=15,8+0,08^{*}$ dose de $\mathrm{N}-0,00044^{*}(\text { dose de } \mathrm{N})^{2}$;

$R^{2}=0,9316^{\star * *}$

A composição isotópica das amostras, de $-11,9$ a $-12,3$, encontra-se dentro da faixa típica verificada para gramíneas tropicais (O’Leary, 1988; Boutton, 1996). Os valores de $\Delta^{13} \mathrm{C}$ mostraram tendência de redução $(\mathrm{P}<0,08)$ com o aumento na dose aplicada de $\mathrm{N}$ : $\Delta^{13} \mathrm{C}=4,299-0,003^{*}$ dose $\left(\mathrm{P}<0,0724 ; \mathrm{R}^{2}=0,2703\right)$.

A ausência de efeito significativo para a discriminação do ${ }^{13} \mathrm{C}$ pode ter sido conseqüência da pequena amplitude nesses valores (cerca de 0,4\%o), resultante do pequeno contraste nos conteúdos de $\mathrm{N}$ nos diferentes tratamentos $(15,8$ a 19,4 g/kg), eq. (4). De acordo com O'Leary (1988) e Boutton (1996), os efeitos de mudanças no ambiente 
e/ou manejo são mais facilmente detectadas quando as diferenças nos valores de $\Delta^{13} \mathrm{C}$ entre tratamentos são superiores a $1 \%$.

Adicionalmente, em todas as espécies de plantas, há variação na composição isotópica nos diferentes tecidos e, portanto, nos valores de $\Delta^{13} \mathrm{C}$. Tecidos da haste normalmente apresentam valores mais negativos de $\delta^{13} \mathrm{C}$ do que o tecido foliar (Boutton, 1996). Portanto, é possível que parte da redução nos valores de $\Delta^{13} \mathrm{C}$, nas maiores adubações com N, seja o resultado da maior proporção de hastes na amostra, uma vez que a adubação nitrogenada estimula o desenvolvimento de hastes (Stobbs, 1975).

Entretanto, as correlações negativas entre os valores de $\Delta^{13} \mathrm{C}$ com a quantidade de $N(r=-0,60 ; P=0,0132)$ e com o conteúdo de $N$ total $(r=-0,61 ; P=0,0115)$, substanciam a proposta de que o "status" menos favorável de $\mathrm{N}$ no sistema determinou ineficiência no processo fotossintético, conforme indicado pela tendência de maior discriminação do ${ }^{13} \mathrm{C}$.

Assim, o processo fotossintético pode ter sido afetado negativamente em razão da reduzida partição da atividade da carboxilase para ribulose 1,5-bifosfato carboxilase em relação à fosfoenolpiruvato carboxilase nas situações de "status" menos favorável de $\mathrm{N}$ (Meinzer \& Zhu, 1998). Esse fato parece indicar que o aumento na perda de $\mathrm{CO}_{2}$ nas células da bainha e a diminuição no rendimento quântico (em associação com o custo energético extra para a planta, porque a ATP é necessária para regeneração da fosfoenolpiruvato carboxilase) podem ser em grande parte atribuídos ao declínio na atividade do ciclo C3 nas células da bainha em relação à atividade do ciclo C4 nas células do mesofilo (Meinzer \& Zhu, 1998).

A discrepância entre os valores de $\mathrm{N}$ crítico proposto para gramíneas forrageiras tropicais (Cruz \& Lemaire, 1996) e o $\mathrm{N}$ total determinado no presente estudo (Figura 2), dão suporte à idéia de que o reduzido conteúdo de $\mathrm{N}$ na planta, resultando em uma possível limitação ao processo fotossintético, determinou produções de forragem subótimas, em especial, nas adubações com 0 e $30 \mathrm{~kg} / \mathrm{ha}$ de $\mathrm{N}$. A correlação positiva entre a massa de forragem e o $\mathrm{N}$ total $(r=0,70 ; P=0,0026)$ e a negativa entre a massa de forragem e $\Delta^{13} \mathrm{C}(r=-0,60 ; P=0,0131)$, subsidiam tal afirmação.

Ademais, o fato de que a relação entre a concentração de $\mathrm{N}$ crítico e a massa de forragem, ilustrada na Figura 2, não varia substancialmente com fatores de ambiente, a não ser com aqueles afetando o suprimento de $\mathrm{N}$ do solo (Lemaire \& Gastal, 1997), é mais um indicativo de que o "status" desfavorável de N no sistema teve impacto negativo sobre a massa de forragem, refletindo, possivelmente, o comprometimento na eficiência do processo fotossintético. 


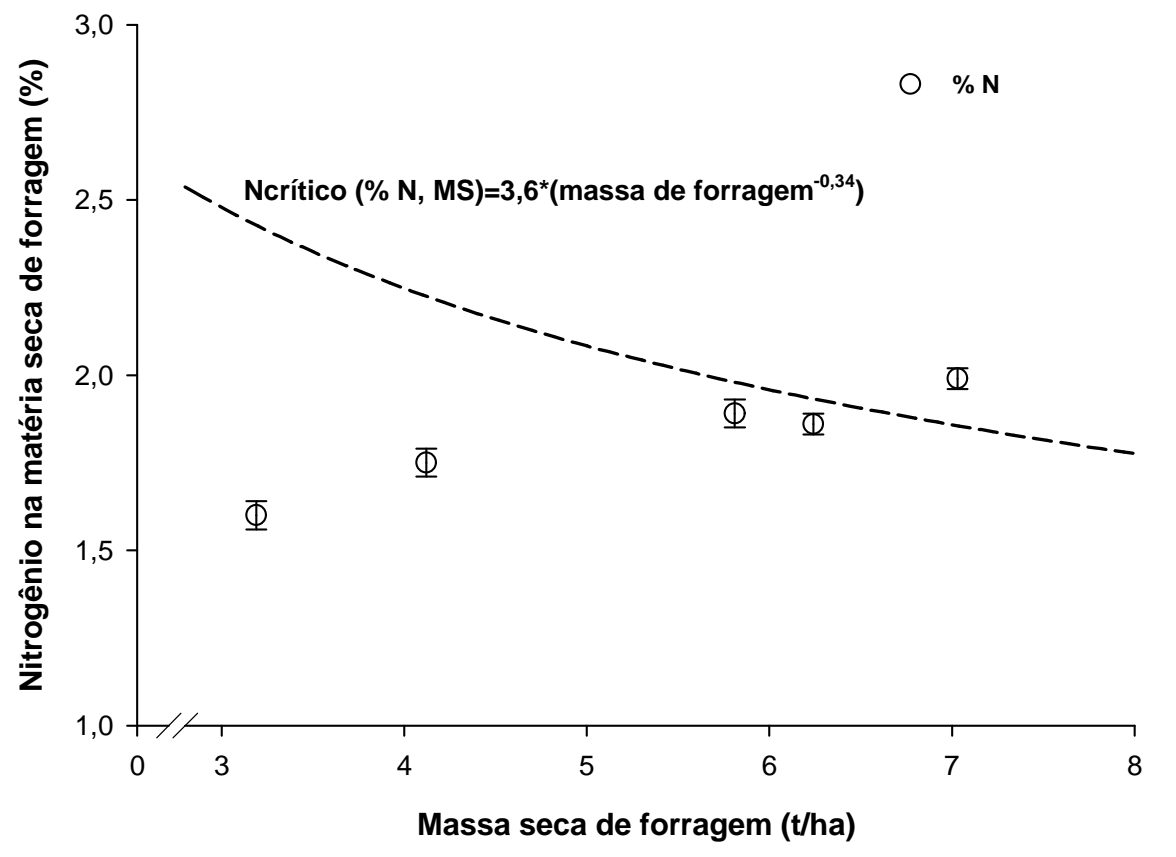

Figura 2 - Teor de nitrogênio (\%N, MS) na planta e massa seca de forragem (t/ha) resultante de adubações com 0, 30, 60, 90 e $120 \mathrm{~kg} / \mathrm{ha}$ de $\mathrm{N}$, em relação ao nível crítico de nitrogênio (linha tracejada) proposto por Cruz \& Lemaire (1996).

Desse modo, a redução na taxa de crescimento da cultura seria proporcional à razão entre o $\mathrm{N}$ total e o $\mathrm{N}$ crítico, que indicaria o índice de nutrição de nitrogênio da cultura (Lemaire \& Gastal, 1997). No presente estudo, a relação $\mathrm{N}$ total/N crítico foi de 0,$66 ; 0,79$; 0,95; 1,07; 0,96 para as adubações com 0, 30, 60, 90 e $120 \mathrm{~kg} / \mathrm{ha}$ de $\mathrm{N}$, respectivamente.

Como comentário final, destaca-se que o uso da discriminação do ${ }^{13} \mathrm{C}$ pode ser uma importante ferramenta para acessar os fluxos de carbono no ecossistema de pastagem em estudos envolvendo diferentes ambientes de produção ou condições de manejo. A facilidade na coleta, processamento e análise das amostras figura como prérequisito favorável à execução de novos trabalhos com essa técnica. Trabalhos futuros com esse método devem considerar situações de maiores contrastes entre os tratamentos (por exemplo uma maior amplitude nos conteúdos de $\mathrm{N}$ na forragem) e a determinação de $\delta^{13} \mathrm{C}$ na fração folha, visando representar melhor a capacidade fotossintética do vegetal e 
eliminar os possíveis problemas na interpretação dos resultados que surgem com uma pequena amplitude nos valores de $\Delta^{13} \mathrm{C}$ (i.e. inferiores a $1 \%$ ).

\subsection{Conclusões}

A discriminação do ${ }^{13} \mathrm{C}$ tendeu a ser menor nos maiores níveis de adubação nitrogenada. Observou-se correlações negativas e significativas entre a discriminação do ${ }^{13} \mathrm{C}$ com a quantidade de nitrogênio, o conteúdo de nitrogênio total na forragem e a massa de forragem. Adubações inferiores a $60 \mathrm{~kg} / \mathrm{ha}$ de $\mathrm{N}$ por ciclo de pastejo determinaram índice de nutrição de nitrogênio da cultura subótimo. 


\section{CONCLUSÕES}

Com base nos experimentos realizados envolvendo pastagem irrigada de capim Tanzânia adubada com fertilizantes nitrogenados conclui-se:

- Para maximizar a produção de folhas e a relação folha/haste, considerando ciclo de pastejo de 36 dias e adubação de $80 \mathrm{~kg} / \mathrm{ha}$ de $\mathrm{N}$ em cada ciclo de pastejo, a massa de forragem residual para o capim Tanzânia, no inverno, deve ser de 1.900 a $2.100 \mathrm{~kg} / \mathrm{ha}$ de massa seca verde. Nas estações de primavera e verão, o resíduo pós-pastejo deve ser de 1.700 a $2.700 \mathrm{~kg} / \mathrm{ha}$ de massa seca verde.

- O aumento na intensidade de pastejo determinou redução na massa da touceira e, quanto menor a touceira, maior foi a sua dependência de nitrogênio do fertilizante.

- Parcelas de $1 \mathrm{~m}^{2}$ foram adequadas para estudos sobre a recuperação do fertilizante-

${ }^{15} \mathrm{~N}$ em pastagem de capim Tanzânia nas épocas de inverno, de primavera e de verão.

- A combinação de elevada umidade do solo, ausência de chuvas durante o primeiro dia depois da adubação e temperatura elevada, no verão, determinou baixa recuperação do nitrogênio do fertilizante no sistema solo-planta e elevadas perdas de amônia por volatilização. Nessas situações, quanto maior a adubação com $\mathrm{N}$-uréia, menor a recuperação do nitrogênio aplicado no sistema solo-planta e maior as perdas acumuladas de amônia. As taxas diárias de volatilização de amônia foram substancialmente reduzidas a partir do dia subseqüente à adubação. Até $16 \%$ do nitrogênio volatilizado da uréia aplicada ao solo foi absorvido pela pastagem de capim Tanzânia durante o verão.

- No verão, a discriminação do ${ }^{13} \mathrm{C}$ tendeu a ser maior nos níveis mais baixos de adubação nitrogenada, possivelmente indicando limitações ao processo fotossintético nessas situações. Adubações inferiores a $60 \mathrm{~kg} / \mathrm{ha}$ de $\mathrm{N}$ por ciclo de pastejo determinaram índice de nutrição de nitrogênio da cultura subótimo. 


\section{REFERÊNCIAS BIBLIOGRÁFICAS}

AARTS, H.F.M.; BIEWINGA, E.E.; VAN KEULEN, H. Dairy farming systems based on efficient nutrient management. Netherlands Journal of Agricultural Science, v.40, p.285-299, 1992.

AARTS, H.F.M.; HABEKOTTÉ, B.; VAN KEULEN, H. Nitrogen (N) management in the "De Marke" dairy farm system. Nutrient Cycling in Agroecosystems, v.56, p.231-240, 2000.

ADEGBOLA, A.A.; ADEPOJU, A. Pasture research in the wet and dry tropics of Nigeria with particular reference to isotope applications. In: NUCLEAR TECHNIQUES IN IMPROVING PASTURE MANAGEMENT, Viena: 1983. Proceedings. Viena: IAEA, 1983. p.93-108.

AGUIAR, A.P.A.; ALMEIDA, B.H.P.J.F.; REIS, G. S. et al. Análise econômica de um sistema intensivo de produção de carne em pastagens dos capins Tanzânia, Panicum maximum Jacq. cv Tanzânia, e Mombaça, Panicum maximum Jacq. cv Mombaça, com animais cruzados, zebu europeu na região do cerrado. (compact disc) In: REUNIÃO ANUAL DA SOCIEDADE BRASILEIRA DE ZOOTECNIA, 39., Recife, 2002. Anais. Recife: SBZ, 2002a.

AGUIAR, A.P.A.; AMARAL, G.C.; DATENA, J.L.F. et al. Produtividade de carne em sistemas intensivos nas pastagens de Mombaça, Tanzânia e Tifton-85 na região do Cerrado. (compact disc) In: REUNIÃO ANUAL DA SOCIEDADE BRASILEIRA DE ZOOTECNIA, 38., Piracicaba, 2001. Anais. Piracicaba: SBZ, 2001. p.1461-1462. 
AGUIAR, A.P.A.; REIS, G. S.; AMARAL, G.C. et al. Produtividade de carne em sistemas intensivos nas pastagens de Mombaça, Tanzânia e Tifton-85 na região do Cerrado. (compact disc). In: REUNIÃO ANUAL DA SOCIEDADE BRASILEIRA DE ZOOTECNIA, 39., Recife, 2002. Anais. Recife: SBZ, 2002b.

ALVIM, M.J.; BOTREL, M.A.; NOVELLY, P.E. Produção de gramíneas tropicais e temperadas irrigadas na época seca. Revista da Sociedade Brasileira de Zootecnia, v.15, p.384-392, 1986.

ANJOS, J.T.; TEDESCO, M.J. Volatilização de amônia proveniente de dois fertilizantes nitrogenados aplicados em solos cultivados. Científica, v.4, p.49-55, 1976.

ARONOVICH, S. O capim colonião e outros cultivares de Panicum maximum (Jacq.): introdução e evolução do uso no Brasil. In: SIMPÓSIO SOBRE O MANEJO DA PASTAGEM, 12., Piracicaba,1995.Anais. Piracicaba: FEALQ, 1995. p.1-20.

ARRUDA, Z.J. A bovinocultura de corte no Brasil e perspectivas para o setor. Campo Grande: Embrapa, CNPGC, 1994. 28p. (Documentos, 60).

ARRUDA, Z.J. A pecuária bovina de corte no Brasil e resultados econômicos de sistemas alternativos de produção. In: SIMPÓSIO SOBRE PECUÁRIA DE CORTE, 4., Piracicaba, 1997. Anais. Piracicaba:FEALQ, 1997. p.259-273.

ASSOCIAÇÃO NACIONAL PARA DIFUSÃO DE ADUBOS E CORRETIVOS AGRÍCOLAS. Relatório anual. São Paulo, 1999. 152p.

AVNIMELECH, Y.; LAHER, M. Ammonia volatilization from soils: equilibrium considerations. Soil Science Society of America Journal, v.41, p.1080-1084, 1977.

BALSALOBRE, M.A.A. Valor alimentar do capim Tanzânia. Piracicaba, 2002. 113p. Tese (Doutorado) - Escola Superior de Agricultura "Luiz de Queiroz", Universidade de São Paulo. 
BARBOSA, M.A.A.F.; DAMASCENO, J.C.; CECATO, U. et al. Estudo do perfilhamento em 4 cultivares de Panicum maximum Jacq. submetidos a duas alturas de corte. In: REUNIÃO ANUAL DA SOCIEDADE BRASILEIRA DE ZOOTECNIA, 33., Fortaleza, 1996. Anais. Fortaleza: SBZ, 1996. p.106-108.

BARBOSA, R.A.; NACIMENTO JUNIOR, D.; EUCLIDES, V.P.B. et al. Características morfogênicas e acúmulo de forragem do capim Tanzânia (Panicum maximum Jacq. cv. Tanzânia) em dois resíduos forrageiros pós-pastejo. Revista Brasileira de Zootecnia, v.31, p.583-593, 2002.

BARIONI, L.G.; MARTHA JÚNIOR, G.B.; RAMOS, A.K.B. et al. Planejamento e gestão do uso de recursos forrageiros na produção de bovinos em pastejo. In: SIMPÓSIO SOBRE O MANEJO DA PASTAGEM, 20., Piracicaba, 2003. Anais. Piracicaba: FEALQ, 2003. prelo.

BARRIE, A.; PROSSER, S.J. Automated analysis of light-elements stable isotopes by isotope ratio mass spectrometry. In: BOUTTON, T.W.; YAMASAHI, S. (Ed.). Mass spectrometry of soils. New York: Marcel Dekker, 1996. p.1-41.

BARTHOLOMEW, W.V. $15 \mathrm{~N}$ in research on the availability and crop use of nitrogen. In: INTERNATIONAL ATOMIC ENERGY AGENCY. Nitrogen-15 in soil-plant studies. Viena: IAEA, 1971. p.1-20.

BERTOL, I.; ALMEIDA, J.A.; ALMEIDA, E.X. et al. Propriedades físicas do solo relacionadas a diferentes níveis de oferta de forragem de capim-elefante anão cv. Mott. Pesquisa Agropecuária Brasileira, v.35, p.1047-1054, 2000.

BLACK, A.S.; SHERLOCK, R.R.; SMITH, N.P. et al. Effects of form of nitrogen, season, and urea application rate on ammonia volatilisation from pastures. New Zealand Journal of Agricultural Research, v.28, p.469-474, 1985.

BLACK, A.S.; SHEROLOCK, R.R.; SMITH, N.P. Effect of timing of simulated rainfall on ammonia volatilisation from urea applied to soil of varying moisture content. Journal of Soil Science, v.38, p.679-688, 1987. 
BLOOM, A.J. Crop acquisition of ammonium and nitrate. In: BOOTE, K.J.; BENNETT, J.M.; SINCLAIR, T.R. et al. (Ed.) Physiology and determination of crop yield. Madison: ASA;CSSA;SSSA, 1994. p.303-309.

BOCKMAN, O.C.; OLFS, $\mathrm{H}$. Fertilizers, agronomy and $\mathrm{N}_{2} \mathrm{O}$. Nutrient Cycling in Agroecosystems, v. 52, p.165-170, 1998.

BODDEY, R.M.; RAO, I.M.; THOMAS, R.J. Nutrient cycling and environmental impact of Brachiaria pastures. In: MILES, J.W.; MAASS, B.L.; VALLE, C.B. (Ed.). Brachiaria: biology, agronomy and improvement. Cali: CIAT;EMBRAPA, CNPGC, 1996. p.72-86.

BODDEY, R.M.; SÁ, J.C.M.; ALVES, B.J.R. et al. The contribution of biological nitrogen fixation for sustainable agricultural systems in the tropics. Soil Biology and Biochemistry, v.29, p. 787-799, 1997.

BONO, J.A.M.; MACEDO, M.C.M.; EUCLIDES, V.B.P. Biomassa área e do sistema radicular e resistência do solo à penetração em pastagens de Panicum maximum Jacq. sob pastejo rotacionado. (compact disc). In: REUNIÃO ANUAL DA SOCIEDADE BRASILEIRA DE ZOOTECNIA, 37., Viçosa, 2000. Anais. Viçosa: SBZ, 2000.

BOUTTON, T.W. Stable carbon isotope ratios of soil organic matter and their use as indicators of vegetation and climate change. In: BOUTTON, T.W.; YAMASAHI, S. (Ed.). Mass spectrometry of soils. New York: Marcel Dekker, 1996. p.47-82.

BOUWMEESTER, R.J.B.; VLEK, P.L.G.; STUMPE, J.M. Effect of environmental factors on ammonia volatilization from urea-fertilized soils. Soil Science Society of America Journal, v.49, n.2, p.376-381, 1985.

BRASIL. Ministério da Agricultura, Pecuária e Abastecimento. Estatísticas da agricultura brasileira. (http://www.agricultura.gov.br , 15 de janeiro de 2002).

BRUCE, R.C.; EBERSOHN, J.P. Litter measurements in two grazed pastures in South East Queensland. Tropical Grasslands, v.16, p.180-185, 1982. 
BUCHMANN, N.; BROOKS, J.R.; RAPP, K.D. et al. Carbon isotope composition of C-4 grasses is influenced by light and water supply. Plant, Cell and Environment, v.19, p.392-402, 1996.

CADISCH, G.; GILLER, K.E. Driven by nature : plant litter quality and decomposition. Wallingford: CAB International, 1997. 409p.

CADISCH, G.; SCHUNKE, R.M.; GILLER, K.E. Nitrogen cycling in a pure grass pasture and a grass-legume mixture on a red latosol in Brazil. Tropical Grasslands, v.28, p.43-52, 1994.

CANTO, M.W.; CECATO, U.; PETERNELLI, M. et al. Efeito da altura do capim Tanzânia diferido nas características da pastagem no período de inverno. Revista Brasileira de Zootecnia, v.30, p.1186-1193, 2001.

CARVALHO, S.R. Influência de dois sistemas de manejo de pastagens na compactação de uma Terra Roxa Estruturada. Piracicaba, 1976. 89p. Dissertação (Mestrado) Escola Superior de Agricultura "Luiz de Queiroz", Universidade de São Paulo.

CATCHPOOLE, V. R. Pathways for losses of fertilizer nitrogen from a Rhodes grass pasture in south-eastern Queensland. Australian Journal of Agricultural Research, v.26, p.259-268, 1975.

CATCHPOOLE, V.R.; HARPER, L.A.; MYERS, R.J.K. Annual losses of ammonia from a grazed pasture fertilized with urea. In: INTERNATIONAL GRASSLAND CONGRESS, 14., Lexington, 1981. Proceedings. Lexington: Westeview Press/Bulder, 1981. p.344347.

CATCHPOOLE, V.R.; OXENHAM, D.J.; HARPER, L.A. Transformation and recovery of urea applied to a grass pasture in south-eastern Queensland. Australian Journal of Experimental Agricultural and Animal Husbandry, v.23, p.80-86, 1983. 
CECATO, U.; CANO, C.C.P.; CANTO, M.W. et al. Disponibilidade de massa seca e conteúdo de minerais em capim Tanzânia (Panicum maximum Jacq.) pastejado em diferentes alturas. (compact disc). In: REUNIÃO ANUAL DA SOCIEDADE BRASILEIRA DE ZOOTECNIA, 39., Recife, 2002. Anais. Recife: SBZ, 2002.

CECATO, U.; CASTRO, C.R.C.; CANTO, M.W. et al. Perdas de forragem em capimTanzânia (Panicum maximum Jacq. cv. Tanzânia-1) manejado sob diferentes alturas sob pastejo. Revista Brasileira de Zootecnia, v.30, p.295-301, 2001.

CECATO, U.; FAVORETTO, V.; MALHEIROS, E.B. Influência da freqüência de corte, de níveis e formas de aplicação de nitrogênio sobre a produção e a taxa de crescimento do capim-aruana. Revista UNIMAR, v.16, p.203-216, 1994. Suplemento.

CECATO, U.; MACHADO, A.O.; MARTINS, E.N. et al. Avaliação da produção e de algumas características da rebrota de cultivares e acessos de Panicum maximum Jacq. sob duas alturas de corte. Revista Brasileira de Zootecnia, v.29, p.660-668, 2000.

CHACÓN-MORENO, E., RADA, F., SAMIENTO, G. Intercambio gaseoso, nitrógeno foliar y optimación en el manejo de Panicum maximum(tipo común) sometido a diferentes frecuencias de corte. Turrialba, v.45, p.19-26, 1995.

COOPER, J.P.; TAINTON, N.M. Light and temperature requirements for the growth of tropical and temperate grasses. Herbage Abstracts, v.38, p.167-176, 1968.

CORRÊA, L.A. Produção de gado de corte em pastagens adubadas. In: SIMPÓSIO GOIANO SOBRE PRODUÇÃO DE BOVINOS DE CORTE, Goiânia, 1999. Anais. Goiânia: CBNA, 1999. p.81-94.

CORSI, M. Effect of nitrogen rates and harvesting intervals on dry matter production, tillering and quality of the tropical grass Panicum maximum, Jacq. Wooster, 1984. 125p. Thesis (Ph.D.) - Ohio State University.

CORSI, M. Pastagens de alta produtividade. In: CONGRESSO BRASILEIRO DE PASTAGENS, 8., Piracicaba, 1986. Anais. Piracicaba: FEALQ, 1986. p. 499-511. 
CORSI, M.; MARTHA JÚNIOR, G.B. Manejo de pastagens para produção de carne e leite. In: SIMPÓSIO SOBRE MANEJO DA PASTAGEM, 15., Piracicaba, 1998. Anais. Piracicaba: FEALQ, 1998. p.55-83.

CORSI, M.; MARTHA JÚNIOR, G.B. Manutenção da fertilidade do solo em sistemas intensivos de pastejo rotacionado. In: SIMPÓSIO SOBRE O MANEJO DA PASTAGEM, 14., Piracicaba, 1997. Anais. Piracicaba: FEALQ, 1997. p.161-192.

CORSI, M.; MARTHA JÚNIOR, G.B.; BALSALOBRE, M.A.A. et al. Tendências e perspectivas da produção de bovinos sob pastejo. In: PEIXOTO, A.M.; PEDREIRA, C.G.S.; MOURA, J.C. et al. (Ed.). A planta forrageira no sistema de produção. Piracicaba: FEALQ, 2001a. p.3-69.

CORSI, M.; MARTHA JÚNIOR, G.B.; PAGOTTO, D.S. Sistema radicular: dinâmica e resposta a regimes de desfolha. In: SILVA, S.C.; PEDREIRA, C.G.S. (Ed.). A produção animal na visão dos brasileiros - pastagens. Piracicaba: FEALQ, 2001b. p.838-852.

CORSI, M.; NUSSIO, L.G. Manejo do capim-elefante: correção e adubação do solo. In: SIMPÓSIO SOBRE O MANEJO DA PASTAGEM, 10., Piracicaba, 1992. Anais. Piracicaba: FEALQ, 1993. p.87-115.

CORSI, M.; SANTOS, P.M. Potencial de produção do Panicum maximum. In: SIMPÓSIO SOBRE MANEJO DA PASTAGEM, 12., Piracicaba, 1995. Anais. Piracicaba: FEALQ, 1995. p.249-266.

COSTA, C.; FAVORETTO, V.; MALHEIROS, E.B. Estudo da variação na estrutura da vegetação de duas cultivares de Panicum maximum Jacq. (Colonião e Tobiatã) submetidas a diferentes tipos de manejo. 1. Produção e densidade de perfilhos e de matéria seca. Pesquisa Agropecuária Brasileira, v.27, p.131-142, 1992.

COSTA, F.P. O produtor, os recursos produtivos e o manejo das pastagens. Campo Grande: Embrapa Gado de Corte, 2000. 34p. (Circular Técnica, 26). 
CRESPO, G. Variation in the response of tropical pastures to nitrogenous fertilizers throughout the year. 3. Guinea grass (Panicum maximum Jacq.) with irrigation. Cuban Journal of Agricultural Science, v.20, p.73-81, 1986.

CRUZ, P.; LEMAIRE, G. Diagnosis of the nitrogen status of grass stands: principles and uses of the dilution curves method. Tropical Grassland, v.30, p.166, 1996.

DAWSON, L.A.; GRAYSTON, S.J.; PATERSON, E. Effects of grazing in the roots and rhizosphere of grasses. In: LEMAIRE, G.; HODGSON, J.; MORAES, A. et al. (Ed.). Grassland ecophysiology and grazing ecology. Wallingford: CAB International, 2000. p.61-84.

DELWICHE, C.C. The nitrogen cycle. Scientific American, v.223, p.137-146, 1970.

DENMEAD, O.T.; FRENEY, J.R.; DUNIN, F.X. et al. Effect of canopy development on ammonia uptake and loss from sugarcane fields fertilized with urea. In: AUSTRALIAN SOCIETY OF SUGARCANE TECHNOLOGISTS CONFERENCE, 15., Cains, 1993. Proceedings. Cains: Watson Ferguson, 1993. p.25-30.

DENMEAD, O.T.; FRENEY, J.R.; JACKSON, A.V. Volatilization of ammonia from urea and ammonium sulfate applied to sugarcane trash in north Queensland. In: AUSTRALIAN SOCIETY OF SUGAR CANE TECHNOLOGISTS CONFERENCE, 12., Journsville, 1990. Proceedings. Journsville: Watson Fergunson, 1990. p.72-78.

DONAGHY, D.J., FULKERSON, W.J. Priority for allocation of water soluble cabohydrate reserves during regrowth of Lolium perenne. Grass and Forage Science, v.53, p.211218, 1998.

ERNST, J.W.; MASSEY, H.F. The effects of several factors on volatilization of ammonia formed from urea in soil. Soil Science Society of America Proceedings, v.24, p.8790, 1960.

ESTEVES, S.N. Custo de produção de carne utilizando pastagens adubadas. In: SIMPÓSIO SOBRE MANEJO E NUTRIÇÃO DE GADO DE CORTE, Goiânia, 2000. Anais. Goiânia: CBNA, 2000. p.25-40. 
EUCLIDES FILHO, K.; FIGUEIREDO, G.R.; EUCLIDES, V.P.B. et al. Desempenho de animais nelore e seus mestiços com caracu, angus e simental. (compact disc). In: REUNIÃO ANUAL DA SOCIEDADE BRASILEIRA DE ZOOTECNIA,36. Porto Alegre, 1999. Anais. Porto Alegre: SBZ, 1999.

EUCLIDES, V.P.B. Valor alimentício de espécies forrageiras do gênero Panicum. In: SIMPÓSIO SOBRE O MANEJO DA PASTAGEM, 12., Piracicaba, 1995. Anais. Piracicaba: FEALQ, 1995. p.245-273.

EUCLIDES, V.P.B.; MACEDO, M.C.M.; OLIVEIRA, M.P. Animal production in tropical pastures recovered by subsoiling and fertilization in the Cerrados of Brazil. In: INTERNATIONAL GRASSLAND CONGRESS, 19., São Pedro, 2001. Proceedings. São Pedro: FEALQ, 2001. p.841-842.

EUCLIDES, V.P.B.; MACEDO, M.C.M.; OLIVEIRA, M.P. Desempenho animal em pastagens de gramíneas recuperadas com diferentes níveis de fertilização. In: REUNIÃO ANUAL DA SOCIEDADE BRASILEIRA DE ZOOTECNIA, 34., Juiz de Fora, 1997. Anais. Juiz de Fora: SBZ, 1997. v.2, p.201-203.

EUCLIDES, V.P.B; ZIMMER, A.H.; OLIVEIRA, M.P. Evaluation of Panicum maximum cultivars under grazing In: INTERNATIONAL GRASSLAND CONGRESS, 17., Palmerston North, 1993. Proceedings. Palmerston North: New Zealand Grassland Association, 1993. p.1999-2000.

FARQUHAR, G.D. On the nature of carbon isotope discrimination in C4 species. Australian Journal of Plant Physiology, v.10, p.205-226, 1983.

FARQUHAR, G.D., FIRTH, P.M., WETSELLAR, R. et al. On the gaseous exchange of ammonia between leaves and the environment: determination of the ammonia compensation point. Plant Physiology, v.66, p.710-714, 1980.

FARQUHAR, G.D.; EHLERINGER, J.R.; HUBICK, K.T. Carbon isotope discrimination and photosynthesis. Annual Review of Plant Physiology and Plant Molecular Biology, v.40, p.503-537, 1989. 
FAVORETTO, V.; CECATO, U.; GUIDELI, C. et al. Avaliação da estrutura da vegetação do capim-colonião em função de práticas de manejo. In: REUNIÃO ANUAL DA SOCIEDADE BRASILEIRA DE ZOOTECNIA, 32., Brasília, 1995. Anais. Brasília: SBZ, 1995. p.45-48.

FAVORETTO, V.; RODRIGUES, L.R.A.; TUPINAMBÁ, L.F. Efeito do nitrogênio na produção e composição bromatológica do capim colonião e seus aspectos econômicos. Científica, v.16, p.71-78, 1988.

FENN, L.B.; HOSSNER, L.R. Ammonia volatilization from ammonium or ammoniumforming nitrogen fertilizers. Advances in Soil Science, v.1, p.123-169, 1985.

FERNANDES, M.S.; ROSSIELO, R.O.P. Aspectos do metabolismo e utilização do nitrogênio em gramíneas tropicais. In: MATTOS, H.B.; WERNER, J.C.; YAMADA, T. et al. (Ed.). Calagem e adubação de pastagens. Piracicaba: Potafós, 1986. p.93-123.

FERREIRA, E.; RESENDE, A.S.; ALVES, B.J.R. et al. Destino do ${ }^{15} \mathrm{~N}$ da urina bovina aplicado na superfície de um solo Podzólico descoberto ou sob cultura de Brachiaria brizantha cv. Marandú. In: REUNIÃO ANUAL DA SOCIEDADE BRASILEIRA DE ZOOTECNIA, 32., Brasília, 1995. Anais. Brasília: SBZ, 1995. p.109-110.

FISHER, M.J.; RAO, I.M.; AYARZA, M.A. et al. Carbon storage by introduced deep-rooted grasses in the South American savannas. Nature, v.371, p.236-238, 1994.

FLOATE, M.J.S. Nitrogen cycling in managed grassland. In: SNAYDON, R.W. (Ed.). Ecosystems of the world 17B: managed grasslands-analytical studies. Amsterdam: Elsevier, 1987. p.163-172.

FOLLET, R.F., PORTER, L.K., HALVORSON, A.D. Border effects on nitrogen-15 fertilized winter wheat microplots grown in the great plains. Agronomy Journal, v.83, p.608612, 1991.

FORAGE AND GRAZING TERMINOLOGY COMMITTEE. Terminology for grazing lands and grazing animals. Journal of Production Agriculture, v.5, p.191-201, 1992. 
FRENEY, J.R.; DENMEAD, O.T.; WOOD, A.W. et al. Factors controlling ammonia loss from trash covered sugarcane fields fertilized with urea. Fertilizer Research, v.31, p.341-349, 1991.

FRENEY, J.R.; SIMPSON, J.R.; DENMEAD, O.T. Volatilization of ammonia. In: FRENEY, J.R.; SIMPSON, J.R. (Ed.). Gaseous loss of nitrogen from plant-soil systems. The Hague: Martinus Nijhoff; Dr. W. Junk, 1983. p.1-32.

GASSER, J.K.R. Some factors affecting the losses of ammonia from urea and ammonium sulfate applied to soils. Journal of Soil Science, v.15, p.258-272, 1964.

GEENS, E.L., DAVIES, G.P., MAGGS, J.M. et al. The use of mean pool abundances to interpret ${ }^{15} \mathrm{~N}$ tracer experiments. II. Application. Plant and Soil, v.131, p.97-105, 1991.

GEORGESON, C.C.; PAYNE, J.E. Investigations of the root development of some forage plants. Manhattan: Kansas State Agricultural College, 1897. 17p. (Bulletin, 75).

GHISI, O.M.A.; ALMEIDA, A.R.P.; ALCANTARA, V.B.G. Avaliação agronômica de seis cultivares de Panicum maximum Jacq sob três níveis de adubação. Boletim da Indústria Animal, v.46, p.1-5, 1989.

GOEDERT, W.J.; RITCHEY, K.D.; SANZONOWICZ, C. Desenvolvimento radicular do capim Andropogon e sua relação com o teor de cálcio no perfil do solo. Revista Brasileira de Ciência do Solo, v.9, p.89-91, 1985.

GOMIDE, J.A. Formação e utilização de capineira de capim-elefante. In: CARVALHO, M.M.; ALVIM, M.J.; XAVIER, D.F. et al. (Ed.). Capim-elefante: produção e utilização. Brasília: EMBRAPA, Serviço de Produção e Informação, 1994. p.79-112.

GOMIDE, J.A.; OBEID, J.A.; RODRIGUES, L.R.A. Fatores morfofisiológicos da rebrota do capim colonião (Panicum maximum). Revista da Sociedade Brasileira de Zootecnia, v.84, p.532-562, 1979.

GRANLI, T.; BOCKMAN, O.C. Nitrous oxide $\left(\mathrm{N}_{2} \mathrm{O}\right)$ emissions from soils in warm climates. Fertilizer Research, v.42, p.159-163, 1995. 
GREGORY, P.J. Root growth and activity. In: BOOTE, K.J.; BENNETT, J.M.; SINCLAIR, T.R. et al. (Ed.). Physiology and determination of crop yield. Madison: ASA;CSSA;SSSA, 1994. p.65-93.

GUELFI FILHO, H. Efeito da irrigação sobre a produtividade do capim-elefante (Pennisetum purpureum Schum.) variedade Napier. Piracicaba, 1972. 77p. Tese (Doutorado) - Escola Superior de Agricultura "Luiz de Queiroz", Universidade de São Paulo.

GUELFI FILHO, H. Efeito da irrigação sobre o capim colonião (Panicum maximum Jacq.). O Solo, v.68, p.12-15, 1976.

HARGROVE, W.L. Soil environmental and management factors influencing ammonia volatilization under field conditions. In: BOCK, B.R.; KISSEL, D.E. (Ed.). Ammonia volatilization from urea fertilizers. Muscle Schoals: Tenessee Valley Authority, 1988. p.17-36. (Bulletin, Y-206).

HARGROVE, W.L.; BOCK, B.R.; RAUNIKAR, R.A. et al. Comparison of a forced-draft technique to nitrogen-15 recovery for measuring ammonia volatilization under field conditions. Soil Science Society of America Journal, v.51, p.124-128, 1987.

HARGROVE, W.L.; KISSEL, D.E. Ammonia volatilization from surface applications of urea in the field and laboratory. Soil Science Society of America Journal, v.43, p.359363, 1979.

HARGROVE, W.L.; KISSEL, D.E.; FENN. L.B. Field measurements of ammonia volatilization from surface-applications of ammonium salts to a calcareous soil. Agronomy Journal, v.69, p.473-476, 1977.

HARPER, L.A.; BUSSINK, D.W.; CORRÉ, W.J. Ammonia transport in a temperate grassland: seasonal transport in relation to soil fertility and crop management. Agronomy Journal, v.88, p.614-621, 1996. 
HARPER, L.A.; CATCHPOOLE, V.R.; DAVIS, R. et al. Ammonia volatilization: soil, plant and microclimate effects on diurnal and seasonal fluctuations. Agronomy Journal, v.75, p.212-218, 1983.

HARPER, L.A.; SHARPE, R.R. Atmospheric ammonia: issues on transport and nitrogen isotope measurement. Atmospheric Environment, v.32, p.273-277, 1998.

HARPER, L.A.; SHARPE, R.R. Nitrogen dynamics in irrigated corn: Soil-plant nitrogen and atmospheric ammonia transport. Agronomy Journal, v.87, p.669-675, 1995.

HARPER, L.A.; SHARPE, R.R.; LANGDALE, G.W. et al. Nitrogen cycling in a wheat crop: soil, plant, and aerial nitrogen transport. Agronomy Journal, v.79, p.965-973, 1987.

HARRIS, W. Defoliation as a determinant of the growth, persistence and composition of pasture. In: WILSON, J.R. (Ed.). Plant relations in pasture. Melbourne: CSIRO, 1978. p.67-85.

HART, P.B.S.; RAYNER, J.H.; JENKINSON, D.S. Influence of pool substitution on the interpretation of fertilizer experiments with ${ }^{15} \mathrm{~N}$. Journal of Soil Science, v.37, p.389403, 1986.

HAYNES, R.J. Mineral nitrogen in the soil-plant system. New York: Academic Press, 1986. 482p.

HAYNES, R.J.; WILLIAMS, P.H. Nutrient cycling and soil fertility in the grazed pasture ecosystem. Advances in Agronomy, v.49, p.119-199, 1993.

HENZELL, E.F. Recovery of nitrogen from four fertilizers applied to Rhodes grass in small plots. Australian Journal of Experimental Agriculture and Animal Husbandry, v.11, p.420-430, 1971.

HENZELL, E.F. The use of nitrogen fertilizers on pastures in the sub-tropics and tropics. In: HENZELL, E.F. (Ed.) A review of nitrogen in the tropics with particular reference to pastures. Wallingford: CAB, 1962. p.161-172. (Bulletin, 46). 
HERLING, V.R.; JANTALIA, C.P.; PIAZZA, C. et al. Fisiologia de perfilhamento do capim mombaça (Panicum maximum Jacq. cv. Mombaça) sob pastejo. In: REUNIÃO ANUAL DA SOCIEDADE BRASILEIRA DE ZOOTECNIA, 35., Botucatu, 1998. Anais. Botucatu: SBZ, 1998. p.533-535.

HERLING, V.R.; RODRIGUES, L.R.A.; NOGUEIRA FILHO, J.C.M. et al. Efeitos de níveis de nitrogênio sobre as cultivares colonião e centenário (Panicum maximum Jacq.). I. Características Fisiológicas. In: REUNIÃO ANUAL DA SOCIEDADE BRASILEIRA DE ZOOTECNIA, 32., Brasília, 1995. Anais. Brasília: SBZ, 1995. p.71-73.

HERLING, V.R.; SISTI, C.P.J.; LUZ, P.H.C. et al. Eliminação de meristema apical e perfilhamento do capim mombaça (Panicum maximum Jacq. cv. Mombaça) sob pastejo. In: SIMPÓSIO INTERNACIONAL GRASSLAND ECOPHYSIOLOGY AND GRAZING ECOLOGY, Curitiba, 1999. Anais. Curitiba: UFPR;UFRGS, 1999. p.375377.

HODGE, A.; ROBINSON, D.; FITTER, A. Are microorganisms more effective than plants at competing for nitrogen? Trends in Plant Science, v.5, p.304-308, 2000.

HODGSON, J. Grazing management: science into practice. New York: Longman, 1990. 203p.

HOLTAN-HARTWIG, L., BOCKMAN, O.C. Ammonia exchange between crops and air. Norwegian Journal of Agricultural Science, suppl. 14, 1994. 41p.

HOPKINS, W.G. Introduction to plant physiology. New York: John Wiley, 1995. 464p.

IMPITHUKSA, V.; BLUE, W.G. Fertilizer nitrogen and nitrogen-15 in three warm-season grasses grown on a Florida Spodossol. Soil Science Society of America Journal, v.49, p.1201-1204, 1985.

IMPITHUKSA, V.; BLUE, W.G.; GRAETZ, D.A. Distribution of applied nitrogen in soilpensacola bahiagrass components as indicated by nitrogen-15. Soil Science Society of America Journal, v.48, p.1280-1284, 1984. 
JANK, L. Melhoramento e seleção de variedades de Panicum maximum. In: SIMPÓSIO SOBRE O MANEJO DA PASTAGEM, 12., Piracicaba, 1995. Anais. Piracicaba: FEALQ, 1995. p.21-58.

JANK, L.; SAVIDAN, Y.H.; SOUZA, M.T.C. et al. Avaliação do germoplasma de Panicum maximum introduzido da África. 1. Produção forrageira. Revista da Sociedade Brasileira de Zootecnia, v.23, p.433-440, 1994.

JARVIS, S.C. Nitrogen management and sustainability. In: CHERNEY, J.H.; CHERNEY, D.J.R. (Ed.). Grass for dairy cattle. Wallingford: CAB International, 1998. p.161-192.

JARVIS, S.C.; PAIN, B.F. Gaseous nitrogen emissions from grasslands. Wallingford: CAB International, 1997. 452p.

JARVIS, S.C.; SCHOLEFIELD, D.; PAIN, B. Nitrogen cycling in grazing systems. In: BACON, P.E. (Ed.). Nitrogen fertilization in the environment. New York: Marcel Dekker, 1995. p.381-419.

JARVIS, S.C.; STOCKDALE, E.A.; SHEPHERD, M.A. et al. Nitrogen mineralization in temperate agricultural soils: processes and measurement. Advances in Agronomy, v.57, p.187-235, 1996.

JENKINSON, D.S. The impact of humans on the nitrogen cycle, with focus on temperate arable agriculture. Plant and Soil, v.228, p.3-15, 2001.

JENKINSON, D.S.; FOX, R.H.; RAYNER, J.H. Interactions between fertilizer nitrogen and soil nitrogen - the so-called "priming effect". Journal of Soil Science, v.36, p.425-444, 1985.

JONES, C.A.; CARABALY, A. Some characteristics of the regrowth of 12 tropical grasses. Tropical Agriculture, v.58, p.37-44, 1981.

KANNO, T., MACEDO, M.C., EUCLIDES, V.P.B. et al. Root biomass of five tropical grass pastures under continuous grazing in Brazilian savannas. Grassland Science, v.45, p.9-14, 1999. 
KIEHL, J.C. Distribuição e retenção da amônia no solo após a aplicação de uréia. Revista Brasileira de Ciência do Solo, v.13, p.75-80, 1989.

KISSEL, D.E.; SMITH, S.J. Fate of fertilizer nitrate applied to coastal bermudagrass on a swelling clay soil. Soil Science Society of America Journal, v.42, p.77-80, 1978.

KORTE, C.J.; WATKIN, B.R.; HARRIS, W. Effects of the timing and intensity of spring grazing on reproductive development, tillering, and herbage production of perennial ryegrass dominant pasture. New Zealand Journal of Experimental Research, v.27, p.135-149, 1984.

KUZYAKOV, Y.; FRIEDEL, J.K.; STAHR, K. Review of mechanisms and quantification of priming effects. Soil Biology and Biochemistry, v.32, p.1485-1498, 2000.

LARA CABEZAS, W.A.R., TRIVELIN, P.C.O.; BOARETTO, A.E. Efeito do tamanho de grânulo e relação N/S da uréia aplicada em superfície na volatilização de amônia sob diferentes umidades iniciais do solo. Revista Brasileira de Ciência do Solo, v.16, p.409-413, 1992.

LARA CABEZAS, W.A.R.; TRIVELIN, P.C.O. Eficiencia de um coletor semi-aberto estático na quantificação de $\mathrm{N}-\mathrm{NH}_{3}$ volatilizado da uréia aplicada ao solo. Revista Brasileira de Ciência do Solo, v.14, p.345-352, 1990.

LARA CABEZAS, W.A.R.; TRIVELIN, P.C.O.; BENDASSOLLI, J.A. et al. Calibration of a semi-open static collector for determination of ammonia volatilization from nitrogen fertilizers. Communications in Soil Science and Plant Analysis, v.30, p.389-406, 1999.

LEAFE, E.L.; PARSONS, A.J. Physiology of growth of a grazed sward. In: INTERNATIONAL GRASSLAND CONGRESS, 14., Lexington, 1981. Proceedings. Lexington: Westeview Press/Bulder, 1981. p.403-406.

LEMAIRE G, GASTAL F. N uptake and distribution in plant canopies. In: Lemaire, G. (Ed.) Diagnosis of the nitrogen status in crops. Heidelberg: Springer-Verlag, 1997. p.343. 
LEMAIRE, G. The physiology of grass growth under grazing: tissue turn-over. In: SIMPÓSIO INTERNACIONAL SOBRE PRODUÇÃO ANIMAL EM PASTEJO, Viçosa, 1997. Anais. Viçosa: UFV, 1997. p.117-144.

LÉON, M.; LAINÉ, P.; OURRY, A. et al. Increased uptake of native soil nitrogen by roots of Lolium multiflorum Lam. after nitrogen fertilization is explained by a stimulation of the uptake process itself. Plant and Soil, v. 173, p.197-203, 1995.

LINN, DM; DORAN, J.W. Effect of water-filled pore space on carbon dioxide and nitrous oxide production in tilled and non-tilled soils. Soil Science Society of America Journal, v.48, p.1267-1272, 1984.

LOCKYER, D.R.; WHITEHEAD, D.C. The uptake of gaseous ammonia by the leaves of Italian ryegrass. Journal of Experimental Botany, v.37, p.919-927, 1986.

LOUAHLIA, S.; LAINÉ, P.; THORNTON, B. et al. The role of N-remobilisation and the uptake of $\mathrm{NH}_{4}{ }^{+}$and $\mathrm{NO}_{3}{ }^{-}$by Lolium perenne $\mathrm{L}$. in laminae growth following defoliation under field conditions. Plant and Soil, v.220, p.175-187, 2000.

LOURENÇO, L.F.; COELHO, R.D. Comparação entre três métodos para determinação da umidade do solo vegetado por capim Tanzânia (Panicum maximum Jacq.). Piracicaba: ESALQ, Departamento de Engenharia Rural, 2000. 22p. (Relatório Final $\mathrm{PIBIC/USP/CNPq)}$

LUDLOW, M.M. Light relations in pastures. In: WILSON, J.R. (Ed.) Plant relations in pastures. Melbourne: CSIRO, 1978. p.17-34.

LUGÃO, S.M.B. Produção de forragem e desempenho animal em pastagens de Panicum maximum Jacq. (acesso BRA-006998) adubadas com nitrogênio na região noroeste do Estado do Paraná. Jaboticabal, 2001. 151p. Tese (Doutorado) - Faculdade de Ciências Agrárias e Veterinárias, Universidade Estadual Paulista. "Júlio de Mesquita Filho". 
MACEDO, M.C.M. Sistemas de produção animal em pasto nas savanas tropicais da América: limitações à sustentabilidade. (compact disc). In: REUNIÓN LATINOAMERICANA DE PRODUCCIÓN ANIMAL, 16., CONGRESO URUGUAYO DE PRODUCCIÓN ANIMAL, 3., Montevideo, 2000. Anales. Montevideo: Alpa, 2000.

MALAVOLTA, E.; VITTI, G.C.; OLIVEIRA, S.A. Avaliação do estado nutricional das plantas. 2.ed. Piracicaba: Potafós, 1997. 319p.

MANNETJE, L't.; PRICHARD, A.J. The effect of daylength and temperature on introduced legumes and grasses for the tropics and subtropics of coastal Australia. Australian Journal of Experimental Agriculture and Animal Husbandry, v.14, p.173-181, 1974.

MARTHA JÚNIOR, G.B. Balanço de ${ }^{15} \mathrm{~N}$ e perdas de amônia por volatilização em pastagem de capim-elefante. Piracicaba, 1999. 75p. Dissertação (Mestrado) - Escola Superior de Agricultura "Luiz de Queiroz", Universidade de São Paulo.

MARTHA JÚNIOR, G.B. Dinâmica do ${ }^{15} \mathrm{~N}$ e ${ }^{34} \mathrm{~S}$ em pastagem irrigada de capim Tanzânia. Piracicaba: ESALQ, 2000. 37p. (Relatório Científico 1999-2000 - Projeto FAPESP 03462-6).

MARTHA JÚNIOR, G.B.; BARIONI, L.G.; CEZAR, I.M.; et al.. Sistemas de produção animal em pastejo: um enfoque empresarial. Planaltina: Embrapa Cerrados, 2002. (Documentos). (no prelo).

MARTHA JÚNIOR, G.B.; VILELA, L. Pastagens no Cerrado: baixa produtividade pelo uso limitado de fertilizantes em pastagens. Planaltina: Embrapa Cerrados, 2002. 32p. (Documentos, 50).

MATTHEW, C.; LEMAIRE, G.; SACKVILLE HAMILTON, N.R. et al. A modified self-thinning equation to describe size/density relationships for defoliated swards. Annals of Botany, v.76, p.579-587, 1995. 
MAYA, F.L.A. Produtividade e viabilidade econômica da recria e engorda de bovinos em pastagens adubadas intensivamente com e sem o uso da irrigação. Piracicaba, 2003. 83p. Dissertação (Mestrado) - Escola Superior de Agricultura "Luiz de Queiroz", Universidade de São Paulo.

MEDINA, E.; MARTINELLI, L.A.; BARBOSA, E. et al. Natural abundance of ${ }^{13} \mathrm{C}$ in tropical grasses from the INPA, Instituto Nacional de Pesquisas da Amazônia, herbarium. Revista Brasileira de Botânica, v.22, p.XX-XX, 1999.

MEINZER, F.C.; ZHU, J. Nitrogen stress reduces the efficiency of the C4 CO2 concentrating system, and therefore quantum yield, in Saccharum (sugarcane) species. Journal of Experimental Botany, v. 49, p.1227-1234, 1998.

MELLO, A.C.L. Efeito de três massas de forragem pós-pastejo em Panicum maximum Jacq. cv. Tanzânia sobre a taxa fotossintética, índice de área foliar e ângulo foliar. Piracicaba, 2002. 67p. Tese (Doutorado) - Escola Superior de Agricultura "Luiz de Queiroz", Universidade de São Paulo.

MIRANDA, C.H.B.; BODDEY, R.M. Estimation of biological nitrogen fixation associated with 11 ecotypes of Panicum maximum grown in nitrogen-15 labeled soil. Agronomy Journal, v.79, p.558-563, 1987.

MIYAZAWA, M.; PAVAN, M.A.; FRANCHINI, J.C. Neutralização da acidez do perfil do solo por resíduos vegetais. Informações Agronômicas, n.92, dez. 2000. 8p.

MUNDY, G.N. Effect of initial soil water content and application of water on urea applied to pasture. Australian Journal of Agricultural Research, v.46, p.821-830, 1995.

MUNDY, G.N.; MASON, W.K. The effect of flood irrigation and nitrogen source on the fate of nitrogen fertilizer applied to pasture. Australian Journal of Agricultural Research, v.40, p.107-116, 1989.

MYERS, R.J.K.; ROBBINS, G.B. Sustaining productive pastures in the tropics. 5 . Maintaining productive sown grass pastures. Tropical Grasslands, v.25, p.104-110, 1991. 
O'LEARY, M.H. Carbon isotopes in photosynthesis. BioScience, v.38, p.328-336, 1988.

O'TOOLE, P.; McGARRY, S.J.; MORGAN, M.A. Ammonia volatilization from urea-treated pasture an tillage soils: effects of soil properties. Journal of Soil Science, v.36, p.613-620, 1985.

OENEMA, O.; GEBAUER, G.; RODRIGUEZ, M. et al. Controlling nitrous oxide emissions from grassland livestock production systems. Nutrient Cycling in Agroecosystems, v.52, p.141-149, 1998.

OLIVEIRA, P.P.A. Manejo da calagem e da fertilização nitrogenada na recuperação de pastagens degradadas de Brachiaria sp. em solos arenosos. Piracicaba, 2001. 110p. Tese (Doutorado) - Centro de Energia Nuclear na Agricultura, Universidade de São Paulo.

OLSON, R.V. Plot size requirements for measuring residual fertilizer nitrogen and nitrogen uptake by corn. Soil Science Society of America Journal, v.44, p.428-429, 1980.

PAGOTTO, D.S. Comportamento do sistema radicular do capim Tanzânia (Panicum maximum Jacq.) sob irrigação e submetido a diferentes intensidades de pastejo. Piracicaba, 2001. 51p. Dissertação (Mestrado) - Escola Superior de Agricultura "Luiz de Queiroz", Universidade de São Paulo.

PARSCH, L.D.; POPPI, M.P.; LOEWER, O.J. Stocking rate risk for pasture-fed steers under weather uncertainty. Journal of Range Management, v.50, p.541-549, 1997.

PARSONS, A.J. The effects of season and management on the growth of grass swards. In: JONES, M.B.; LAZENBY, A. (Ed.). The grass crop: the physiological basis of production. London: Chapman \& Hall, 1988. p.129-177.

PARSONS, A.J.; CHAPMAN, D.F. The principles of pasture growth and utilization. In: HOPKINS, A. (Ed.). Grass : its production and utilization. Oxford: Blackwell Science, 2000. p.31-89. 
PARSONS, A.J.; LEAFE, E.L.; COLLET, B. et al. The physiology of grass production under grazing. 1. Characteristics of leaf and canopy photosynthesis of continuously grazed swards. Journal of Applied Ecology, v.20, p.117-126, 1983.

PARSONS, J.J. Spread of african pasture grasses to the american tropics. Journal of Range Management, v.25, p.12-17, 1972.

PARTON, W.J.; MORGAN, J.A.; ALTENHOFEN, J.M. et al. Ammonia volatilization from spring wheat plants. Agronomy Journal, v.80, p.419-425, 1988.

PAULINO, V.T.; BEISMAN, D.A.; FERRARI JUNIOR., E. Fontes de nitrogênio na recuperação de pastagens de Brachiaria decumbens durante o período da seca. Pasturas Tropicales, v.17, p.20-24, 1995.

PENATI, M.A. Estudo do desempenho animal e produção do capim Tanzânia (Panicum maximum Jacq.) em um sistema rotacionado de pastejosob irrigação em três níveis de resíduo pós-pastejo. Piracicaba, 2002. 117p. Tese (Doutorado) - Escola Superior de Agricultura "Luiz de Queiroz", Universidade de São Paulo.

PING, J.; BREMER, E.; JANZEN, H.H. Foliar uptake of volatilized ammonia from surfaceapplied urea by spring wheat. Communications in Soil Science and Plant Analysis, v.31, p.165-172, 2000.

PINSTRUP-ANDERSEN, P.; PANDYA-LORCH, R.; ROSEGRANT, M.W. World food prospects: critical issues for the early twenty-first century. Washington: IFPRI, Food Policy Report, 1999. 32p.

POWLSON, D.S., BARRACLOUGH, D. Mineralization and assimilation in soil-plant system. In: KNOWLES, R.; BLACKBUM, T.H. (Ed.). Nitrogen isotope techniques. San Diego: Academic Press, 1993. p.209-242.

POWLSON, D.S.; PRUDEN, G.; JOHNSTON, A.E. et al. The nitrogen cycle in the broadbalk wheat experiment: recovery and losses of ${ }^{15} \mathrm{~N}$-labelled fertilizer applied in spring and inputs of nitrogen from the atmosphere. Journal of Agricultural Science, v.107, p.591-609, 1986 
PRASERTSEK, P.; FRENEY, J.R.; DENMEAD, O.T. et al. Significance of gaseous nitrogen loss from a tropical dairy pasture fertilised with urea. Australian Journal of Experimental Agriculture, v.41, p.625-632, 2001.

PRIMAVESI, O.; CORRÊA, L.A.; PRIMAVESI, A.C. et al. Adubação com uréia em pastagem de Cynodon dactylon cv. Coastcross sob manejo rotacionado: eficiência e perdas. São Carlos: Embrapa Pecuária Sudeste, 2001. 42p. (Circular Técnica, 30).

PRINS, W.H.; ARNOLD, G.H. The role of nitrogen in intensive grassland production. Wageningen: European Grassland Federation, 1980. 171p.

QUADROS, D.G.; RODRIGUES, L.R.A.; FAVORETTO, V. et al. Componentes da produção de forragem em pastagens dos capins Tanzânia e Mombaça adubadas com quatro doses de NPK. Revista Brasileira de Zootecnia, v.31, p.1333-1342, 2002.

QUEIROZ, NETO, F.; MARTHA JÚNIOR, G.B.; PENATI, M.A. et al. Impact of increasing nitrogen fertilizer rates upon an irrigated Tanzania grass pasture. 1. Dry matter yield. (compact disc). In: INTERNATIONAL GRASSLAND CONGRESS, 19., São Pedro, 2001. Proceedings. São Pedro: FEALQ, 2001.

RAGLAND, J.L.; COLEMAN, N.T. The effect of soil solution aluminum and calcium on root growth. Soil Science Society of America Proceedings, v.23, p.355-357, 1959.

RAO, A.C.S.; SMITH, J.L.; PARR, J.F. et al. Considerations in estimating nitrogen recovery efficiency by the difference and isotopic dilution methods. Fertilizer Research, v.33, p.209-217, 1992.

RAPPAPORT, B.D.; AXLEY, J.H. Potassium chloride for improved urea fertilizer efficiency. Soil Science Society of America Journal, v.48, p.399-401, 1984.

RASSINI, J.B. Avaliação das respostas das forrageiras Tanzânia (Panicum maximum) e capim-elefante (Pennisetum purpureum) à irrigação na região sudeste do Brasil. (compact disc). In: REUNIÃO ANUAL DA SOCIEDADE BRASILEIRA DE ZOOTECNIA, 34., Recife, 2002. Anais. Recife: SBZ, 2002. 
REIS, V.M.; REIS JUNIOR; F.B.; QUESADA, D.M. et al. Biological nitrogen fixation associated with tropical pasture grasses. Australian Journal of Plant Physiology, v.28, p.837-844, 2001.

RESENDE, C.P.; CANTARUTTI, R.B.; GOMIDE, J.A. et al. Litter deposition and disappearance in Brachiaria pastures in the Atlantic forest region of the South of Bahia, Brazil. Nutrient Cycling in Agroecosystems, v.54, p.99-112, 1999.

REYNOLDS, C.M.; WOLF, D.C. Influence of urease activity and soil properties on ammonia volatilization from urea. Soil Science, v.143, p.418-425, 1987.

REYNOLDS, C.M.; WOLF, D.C.; ARMBRUSTER, J.A. Factors related to urea hydrolysis in soils. Soil Science Society of America Journal, v.49, p.104-108, 1985.

RICHARDS, J.H. Physiology of plant recovering from defoliation. In: BAKER, M.J. (Ed.). Grasslands for our world. Wellington: Sir Publishing, 1993. p.46-54.

ROBBINS, G.B.; BUSHELL, J.J.; McKEON, G.M. Nitrogen immobilization in decomposing litter contributes to productivity decline in ageing pastures of green panic (Panicum maximum var. Trichoglume). Journal of Agricultural Science, v.113, p.401-406, 1989.

ROBSON, M.J. Potential production - what is it and can we increase it? In: WRIGHT, C.E. (Ed.). Plant Physiology and herbage production. Nottingham: British Grassland Society, 1981. p.5-18.

RODRIGUES, A.C.G.; CADIMA-ZEVALLOS, A. Efeito da intensidade de pastejo sobre o sistema radicular de pastagem. Pesquisa Agropecuária Brasileira, v.26, p.439-445, 1991.

RODRIGUES, L.R.A.; REIS, R.A. Bases para o estabelecimento do manejo de capins do gênero Panicum. In: SIMPÓSIO SOBRE O MANEJO DA PASTAGEM, 12., Piracicaba, 1995. Anais. Piracicaba: FEALQ, 1995. p.197-218. 
RODRIGUES, L.R.A.; RODRIGUES, T.J.D. Ecofisiologia de plantas forrageiras. In: CASTRO, P.R.C., FERREIRA, S.O., YAMADA, T. (Ed.). Ecofisiologia da produção agrícola. Piracicaba: Potafós, 1987. p.203-230.

RODRIGUES, M.B.; KIEHL, J.C. Distribuição e nitrificação da amônia proveniente da uréia aplicada ao solo. Revista Brasileira de Ciência do Solo, v.16, n.3, p.403-408, 1992.

RODRIGUES, M.B.; KIEHL, J.C. Volatilização de amônia após o emprego de uréia em diferentes doses e modos de aplicação. Revista Brasileira de Ciência do Solo, v.10, p.37-43, 1986.

RUSSELLE, M.P. Nitrogen cycling in pasture systems. In: JOOST, R.E.; ROBERTS, C.A. (Ed.). Nutrient cycling in forage systems. Columbia: PPI;FAR, 1996. p.125-166.

SALLES, P.A.A.; GONÇALVES, J.O.N. Quantidade ótima econômica de nitrogênio usado em capim Pangola e sua determinação pelo preço relativo atualizado do fator. Pesquisa Agropecuária Brasileira, v.17, p.1105-1111, 1982.

SANCHEZ, C.A.; BLACKMER, A.M., HORTON, R. et al. Assessment of errors associated with plot size and lateral movement of nitrogen-15 when studying fertilizer recovery under field conditions. Soil Science, v.144, p.344-351, 1987.

SANCHEZ, P.A. Management and properties of soils in the tropics. New York: John Willey, 1976. 618p.

SANTOS, P.M. Controle do desenvolvimento das hastes no capim Tanzânia: um desafio. Piracicaba, 2002. 98p. Tese (Doutorado) - Escola Superior de Agricultura "Luiz de Queiroz", Universidade de São Paulo.

SANTOS, P.M. Estudo de algumas características agronômicas de Panicum maximum (Jacq.) cvs. Tanzânia e Mombaça para estabelecer seu manejo. Piracicaba, 1997. 62p. Dissertação (Mestrado) - Escola Superior de Agricultura "Luiz de Queiroz", Universidade de São Paulo. 
SANTOS, P.M.; CORSI, M.; BALSALOBRE, M.A.A. Efeito da freqüência de pastejo e da época do ano sobre a produção e qualidade em Panicum maximum cvs. Tanzânia e Mombaça. Revista Brasileira de Zootecnia, v.28, p.244-249, 1999.

SANTOS, P.M.; THORNTON, B.; CORSI, M. Nitrogen dynamics in the intact grasses Poa trivialis and Panicum maximum receiving contrasting supplies of nitrogen. Journal of Experimental Botany, v.53, p.21677-2176, 2002.

SÃO PAULO. Secretaria de Agricultura e Abastecimento. LUPA (Levantamento Censitário de Unidades de Produção Agrícola). São Paulo, 1997. 4v.

SÃO PAULO. Secretaria de Agricultura e Abastecimento. Relatório. São Paulo, 2000. 1v.

SAS INSTITUTE. SAS/STAT user's guide, version 6. 4. ed. Cary, 1989. 943p.

SCHLESINGER, W.H. Biogeochemistry. 2.ed. San Diego: Academic Press, 1997. 588p.

SCHOLEFIELD, D.; LOCKYER, D.R.; WHITEHEAD, D.C. et al. A model to predict transformations and losses of nitrogen in UK pastures grazed by beef cattle. Plant and Soil, v.132, p.165-177, 1991.

SCHOLEFIELD, D.; OENEMA, O. Nutrient cycling within temperate agricultural grasslands. (compact disc). In: INTERNATIONAL GRASSLAND CONGRESS, 18., Winippeg, 1997. Proceedings. Winippeg CFC;CSA;CSAS, 1999.

SCURLOCK, J.M.O.; HALL, D.O. The global carbon sink: a grassland perspective. Global Change Biology, v.4, p.229-233, 1998.

SHARPE, R.R.; HARPER, L.A. Soil, plant and atmospheric conditions as they relate to ammonia volatilization. Fertilizer Research, v.42, n.1/3, p.149-158, 1995.

SHEPHERD, M.A.; STOCKDALE, E.A.; POWLSON, D.S. et al. The influence of organic nitrogen mineralization on the management of agricultural systems in UK. Soil Use and Management, v.12, p.76-85, 1996. 
SILVA, A.P.; TORMENTA, C.A.; MAZZA, J.A. Manejo físico de solos sob pastagem. In: SIMPÓSIO SOBRE O MANEJO DA PASTAGEM, 14., Piracicaba, 1997. Anais. Piracicaba: FEALQ, 1997. p.25-37.

SMIL, V. Global population and the nitrogen cycle. Scientific American, v., p.58-63, 1997.

SOLLENBERGER, L.E.; BURNS, J.C. Canopy characteristics, ingestive behaviour and herbage intake in cultivated tropical grasslands. In: INTERNATIONAL GRASSLAND CONGRESS, 19., São Pedro, 2001. Proceedings. Piracicaba: FEALQ, 2001. p.321327.

SOMMER, S.G., JENSEN, E.S., SCHJORRING, J.K. Leaf absorption of atmospheric ammonia emitted from pig slurry applied beneath the canopy of winter wheat. Acta Agriculturae Scandinavica, v.43, p.21-24, 1993.

SPAIN, J.M.; SALINAS, J.G. A reciclagem de nutrientes nas pastagens tropicais. In: SIMPÓSIO SOBRE RECICLAGEM DE NUTRIENTES E AGRICULTURA DE BAIXOS INSUMOS NOS TRÓPICOS, Ilhéus, 1984. Anais. Ilhéus: Ceplac, 1985. p.259-299.

STEELE, K.W. Nitrogen losses from managed grasslands. In: SNAYDON, R.W. (Ed.). Managed grasslands/analytical studies. Amsterdam: Elsevier, 1987. p.197-204. (Ecosystems of the world, $17 \mathrm{~B}$ )

STEVENSON, F.J.; COLE, M.A. Cycles of soil : carbon, nitrogen, phosphorus, sulfur, micronutrients. 2.ed. New York: John Willey, 1999. 427p.

STOBBS, T.H. The effects of plant structure on the intake of tropical pastures. III Influence of fertilizer nitrogen on the size of bite harvested by Jersey cows grazing Setaria anceps cv. Kazungula swards. Australian Journal of Agricultural Research, v.24, p.997-1007, 1975.

STOUT, W.L. Evaluating the "added nitrogen interaction" effect in forage grasses. Communication in Soil Science and Plant Analysis, v.26, p.2829-2841, 1995. 
STUMPE, J.M.; VLEK, P.L.G.; LINDSAY, W.L. Ammonia volatilization from urea and urea phosphates in calcareous soils. Soil Science Society of America Journal, v.48, p.921-927, 1983.

TAIZ, L.; ZEIGER, E. Plant physiology. San Diego: The Benjamin/Cummings, 1991. $565 p$.

TEITZEL, J.K. Productive and stable pasture systems for cattle fattening in the humid tropics. 3. Development and use of a computer model to evaluate management options. Agricultural Systems, v.36, p.279-296, 1991.

TERMAN, G.L. Volatilization losses of nitrogen as ammonia from surface-applied fertilizers, organic amendments and crop residues. Advances in Agronomy, v.31, p.189-233, 1979.

THOMAS, R.J. Role of legumes in providing $\mathrm{N}$ for sustainable tropical pasture systems. Plant and Soil, v.174, p.103-118, 1995.

THOMAS, R.J. The role of the legume in the nitrogen cycle of productive and sustainable pastures. Grass and Forage Science, v.47, p.133-142, 1992.

THOMAS, R.J.; ASAKAWA, N.M. Decomposition of leaf litter from tropical forage grasses and legumes. Soil Biology and Biochemistry, v.25, p.1351-1361, 1993.

THORNTON, B.; MILLARD, P. Effects of severity of defoliation on root functioning in grasses. Journal of Range Management, v.49, p.443-447, 1996.

THORNTON, B.; MILLARD, P. The effects of nitrogen supply and defoliation on the seasonal internal cycling of nitrogen in Molinia caerulea. Journal of Experimental Botany, v.44, p.531-536, 1993.

TILMAN, D. Global environmental impacts of agricultural expansion: the need for sustainable and efficient practices. Proceedings of the National Academy of Science of the USA, v.96, p.5995-6000, 1999. 
TORELLO, W.A.; WEHNER, D.J. Urease activity in a Kentucky bluegrass turf. Agronomy Journal, v.75, p.654-656, 1983.

TOSI, P. Estabelecimento de parâmetros agronômicos para o manejo e eficiência de utilização de Panicum maximum cv. Tanzânia 1 sob pastejo rotacionado. Piracicaba, 1999. 103p. Dissertação (Mestrado) - Escola Superior de Agricultura "Luiz de Queiroz", Universidade de São Paulo.

TRIVELIN, P.C.O.; LARA CABEZAS, W.A.R.; BOARETTO, A.E. Dinâmica do nitrogênio de fertilizantes fluidos no sistema solo-planta. In: VITTI, G.C.; BOARETTO, A.E. (Ed.). Fertilizantes fluidos. Piracicaba: Potafos, 1994a. p.314-330.

TRIVELIN, P.C.O.; LARA CABEZAS, W.A.R.; VICTORIA, R.L. et al. Evaluation of a 15N plot design for estimating plant recovery of fertilizer nitrogen applied to sugarcane. Scientia Agricola, v.51, p.226-234, 1994b.

TURNER, N.C.; BEGG, J.E. Responses of pasture plants to water deficits. In: WILSON, J.R. (Ed.) Plant relations in pastures. Melbourne: CSIRO, 1978. p.50-66.

URQUIAGA, S.; VICTORIA, R.L.; BUITRÓN, F. et al. Perdas por volatilização de ${ }^{15} \mathrm{~N}$-uréia e ${ }^{15} \mathrm{~N}$-sulfato de amônio num solo calcário da parte central da região costeira do Peru. Pesquisa Agropecuária Brasileira, v.24, p.607-613, 1989.

URQUIGA, S.; CADISCH, G.; ALVES, B.J.R. et al. Influence of decomposition of roots of tropical forage species on the availability of soil nitrogen. Soil Biology and Biochemistry, v.30, p.2099-2106, 1998.

VALLIS, I.; HENZELL, E.F.; MARTIN, A.E. et al. Isotopic studies on the uptake of nitrogen by pasture plants. V. $15 \mathrm{~N}$ balance experiments in field microplots. Australian Journal of Agricultural Research, v.24, p.693-702, 1973.

VELDKAMP, E.; KELLER, M.; NUÑEZ, M. Effects of pasture management on $\mathrm{N}_{2} \mathrm{O}$ and NO emissions from soils in the humid tropics of Costa Rica. Global Biogeochemical Cycles, v.12, p.71-79, 1998. 
VELTHOF, G.L.; OENEMA, O. Nitrous oxide emission from dairy farming systems in The Netherlands. Netherlands Journal of Agricultural Science, v.45, p.347-360, 1997.

VICENTE-CHANDLER, J.; ABRUÑA, F.; CARO-COSTAS, R. et al. Intensive grassland management in the humid tropics of Puerto Rico. Rio Piedras: University of Puerto Rico, 1974. 164p. (Bulletin, 233).

VICENTE-CHANDLER, J.; SILVA, S.; FIGARELLA, J. Effect of frequency of application on response of guinea grass to nitrogen fertilization. Journal of the University of Puerto Rico, v. 46, p.342-349, 1962.

VICENTE-CHANDLER, J.; SILVA, S.; FIGARELLA, J. The effect of nitrogen fertilization and frequency of cutting on the yield and composition of three tropical grasses. Agronomy Journal, v.51, p.202-206, 1959.

VILELA, L.; GUERRA, A.L.; LEITE, G.G. Manejo da irrigação e do nitrogênio em gramíneas forrageiras no Cerrado. Planaltina: Embrapa Cerrados, 2003. 21p. (Relatório Final de Pesquisa - Projeto 01.2000.347-03)

VILELA, L.; MIRANDA, J.C.C.; SHARMA, R.D. et al. Integração lavoura/pecuária: atividades desenvolvidas pela Embrapa Cerrados. Planaltina: Embrapa Cerrados, 1999. 31p. (Documentos, 9).

VILELA, L.; SOARES, W.V.; SOUSA, D.M.G. et al. Calagem e adubação para pastagens na região do Cerrado. Planltina: Embrapa Cerrados, 2000. 15 p. (Circular Técnica, 37).

VITTI, A.C. Utilização pela cana-de-açúcar (cana planta) do nitrogênio da uréia $\left({ }^{15} \mathrm{~N}\right)$ e do mineralizado no solo em sistemas de manejo com e sem a queima. Piracicaba, 1998. 93p. (Mestrado) - Centro de Energia Nuclear na Agricultura, Universidade de São Paulo.

VITTI, G.C.; TAVARES JUNIOR, J.E.; LUZ, P.H.C. et al. Influência da mistura de sulfato de amônio com uréia sobre a volatilização de nitrogênio amoniacal. Revista Brasileira de Ciência do Solo, v.26, p.663-671, 2002. 
VOLK, G.M. Volatile loss of ammonia following surface application of urea to turf or bare soils. Agronomy Journal, v.51, p.746-749, 1959.

WATSON, C.J., STEVENS, R.J., LAUGHLIN, R.J. et al. Volatilization of ammonia from solid and liquid urea surface-applied to perennial ryegrass. Journal of Agricultural Science, v.119, p.223-226, 1992.

WEDIN, D.A. Nutrient cycling in grasslands: an ecologist's perspective. In: JOOST, R.E.; ROBERTS, C.A. (Ed.). Nutrient cycling in forage systems. Columbia: PPI/FAR, 1996. p.29-44.

WELLES, J.M.; NORMAN, J.M. Instrument for indirect measurement of canopy architecture. Agronomy Journal, v. 83, p. 818-825, 1991.

WERNER, J.C.; PAULINO, V.T.; CANTARELLA et al. Forrageiras. In: VAN RAIJ, B.; CANTARELLA, H.; QUAGGIO, J.A. et al. (Ed.). Recomendações de adubação e calagem para o Estado de São Paulo. 2.ed. Campinas: IAC, 1996. p.261-273. (Boletim Técnico, 100).

WESTERMAN, R.L.; KURTZ, L.T. Isotopic and nonisotopic estimations of fertilizer nitrogen uptake by sudangrass in field experiments. Soil Science Society of America Proceedings, v.38, p.107-109, 1974.

WESTERMAN, R.L.; KURTZ, L.T.; HAUCK, R.D. Recovery of ${ }^{15} \mathrm{~N}$-labeled fertilizers in field experiments. Soil Science Society of America Proceedings, v.36, p.82-86, 1972.

WHITEHEAD, D.C. Grassland nitrogen. Wallingford: CAB International, 1995. 397p.

WHITEHEAD, D.C. Nutrient elements in grasslands: soil-plant-animal relationships. Wallingford: CAB, 2000. 369p.

WHITEHEAD, D.C.; LOCKYER, D.R. The influence of the concentration of gaseous ammonia on its uptake by the leaves of Italian Ryegrass, with and without an adequate supply of nitrogen to the roots. Journal of Experimental Botany, v.38, p.818-827, 1987. 
WHITEHEAD, D.C.; RAISTRICK, N. Ammonia volatilisation from five nitrogen compounds used as fertlizers following suface application to soils. Journal of Soil Science, v.41, p.387-394, 1990.

WILSON, J.R. Comparative response to nitrogen deficiency of a tropical and temperate grass in the interrelation between photosynthesis, growth, and the accumulation of non-structural carbohydrate. Netherlands Journal of Agricultural Science, v.23, p.104-112, 1975b.

WILSON, J.R. Influence of temperature and nitrogen on growth, photosynthesis and accumulation of non-structural carbohydrate in a tropical grass, Panicum maximum var. Trichoglume. Netherlands Journal of Agricultural Science, v.23, p.48-61, 1975a.

WILSON, J.R. Advances in nitrogen cycling in agricultural ecosystems. Wallingford: CAB International, 1988. 451p.

ZIMMER, A.H. Efeito de níveis de nitrogênio e de resíduos pós-pastejo sobre a produção, a estrutura e a qualidade das cultivares Aruana e Vencedor de Panicum maximum Jacq. Jaboticabal, 1999. 208p. Tese (Doutorado) - Faculdade de Ciências Agrárias e Veterinárias, Campus de Jaboticabal, Universidade Estadual Paulista "Julio de Mesquita Filho".

ZOBY, J.L.F.; KORNELIUS, E.; SAUERESSIG, M.G. Pastagens nativas, melhoradas e cultivadas em áreas de Cerrado na recria de fêmeas de reposição. In: EMPRESA BRASILEIRA DE PESQUISA AGROPECUÁRIA. Centro de Pesquisas Agropecuária dos Cerrados. Relatório técnico anual - 1982.1985. Planaltina, 1987. p.404-408. 